Portland State University

PDXScholar

\title{
"As Long as the Mighty Columbia River Flows": the Leadership and Legacy of Wilson Charley, a Yakama Indian Fisherman
}

David-Paul Brewster Hedberg

Portland State University

Follow this and additional works at: https://pdxscholar.library.pdx.edu/open_access_etds

Part of the History Commons

Let us know how access to this document benefits you.

\section{Recommended Citation}

Hedberg, David-Paul Brewster, "'As Long as the Mighty Columbia River Flows": the Leadership and Legacy of Wilson Charley, a Yakama Indian Fisherman" (2017). Dissertations and Theses. Paper 3516.

https://doi.org/10.15760/etd.5400

This Thesis is brought to you for free and open access. It has been accepted for inclusion in Dissertations and Theses by an authorized administrator of PDXScholar. Please contact us if we can make this document more accessible: pdxscholar@pdx.edu. 
"As Long as the Mighty Columbia River Flows":

The Leadership and Legacy of Wilson Charley, a Yakama Indian Fisherman

by

David-Paul Brewster Hedberg

A thesis submitted in partial fulfillment of the requirements for the degree of

Master of Arts

in

History

Thesis Committee:

Katrine Barber, Chair

Catherine McNeur

Tim Garrison

Virginia Butler

Portland State University

2017 
C 2017 David-Paul B. Hedberg 


\begin{abstract}
On March 10, 1957, the United States Army Corps of Engineers completed The Dalles Dam and inundated Celilo Falls, the oldest continuously inhabited site in North America and a cultural and economic hub for Indigenous people. In the negotiation of treaties between the United States, nearly one hundred years earlier, Indigenous leaders reserved access to Columbia River fishing sites as they ceded territory and retained smaller reservations. In the years before the dam's completion, leaders, many of who were the descendants of earlier treaty signatories, attempted to stop the dam and protect both fishing sites from the encroachment of state and federal regulations and archaeological sites from destruction. This study traces the work of Wilson Charley, a Native fisherman, a member of the Yakama Nation's Tribal Council, and great-grandson of one of the 1855 treaty signatories. More broadly, this study places Indigenous actors on a twentieth-century Columbia River while demonstrating that they played active roles in the protest and management of areas affected by The Dalles Dam.

Using previously untapped archival sources - a substantial cache of letters - my analysis illustrates that Charley articulated multiple strategies to fight The Dalles Dam and regulations to curtail Native's treaty fishing rights. Aiming to protect the 1855 treaty and stop The Dalles Dam, Charley created Native-centered regulatory agencies. He worked directly with politicians and supported political candidates, like Richard Neuberger, that favored Native concerns. He attempted to build partnerships with archaeologists and landscape preservationists concerned about losing the area's rich cultural sites. Even after the dam's completion, he conceptualized multiple tribal
\end{abstract}


economic development plans that would allow for Natives' cultural and economic survival.

Given the national rise of technological optimism and the willingness for the federal government to terminate its relationship with federally recognized tribes, Charley realized that taking the 1855 treaty to court was too risky for the political climate of the 1950s. Instead, he framed his strategies in the language of twentieth-century conservation, specifically to garner support from a national audience of non-natives interested in protecting landscapes from industrial development. While many of these non-native partners ultimately failed him, his strategies are noteworthy for three reasons. First, he cast the fight to uphold Native treaty rights in terms that were relevant to nonnatives, demonstrating his complex understanding of the times in which he lived. Second, his strategies continued an ongoing struggle for Natives to fish at their treaty-protected sites, thereby documenting an overlooked period between the fishing rights cases of the turn of the twentieth century and the 1960s and 1970s. Charley left a lasting legacy that scholars have not recognized because many of his visionary ideas came to fruition decades later. Finally, my analysis of Charley's letters also documents personal details that afford readers the unique perspective of one Indigenous person navigated through a tumultuous period in the Pacific Northwest and Native American history. 


\section{Dedication}

\section{I dedicate this thesis to Wilson Charley.}

A man that I never met, I came to know him through his many letters.

Despite all his struggles, he always managed to go fishing. 


\section{Acknowledgements}

Writing this thesis has been one of the most challenging and yet rewarding accomplishments in my life. It began with a suggestion from my advisor Katy Barber to investigate the letters of Wilson Charley in the James James Papers at the University of Oregon Archives and Special Collections. Without her, this thesis would not exist. I will never be able to fully thank and express all that Katy has done for me. She cultivated my interest in the history of the Pacific Northwest, trained me in public history, and has been an inspiring, supportive, and critical mentor. Katy kept me accountable on my writing and provided the substantive feedback to improve my messy drafts and my numerous, often distracting, side projects. I am grateful to David A. Johnson, Carl Abbott, Susan Wladaver-Morgan, Marc S. Rodriguez, and Brenda Frink of the Pacific Historical Review. Working with two fabulous editorial teams enriched my graduate studies, demystified the world of journal publications, and helped me grow as a historian and professional. Professor Catherine McNeur provided a seemingly endless supply of much needed critical feedback throughout my writing and research, and I will sincerely miss the office sessions with her discussing readings in environmental history and the contours of the field. I was also fortunate to receive an undergraduate foundation in American Indian policy from Professor Tim Garrison and an appreciation for archaeology from Professor Virginia L. Butler. My thesis committee has shaped me as a student, and I will always take their training, advice, and critiques with me as I practice the historian's craft. Thank you for braving the ice storms for my defense! 
Years ago, in the midst of the Great Recession, I was fortunate to be hired by Celia Moret-Ferguson as an Archaeological Field Technician. Celia kept me employed for four years and sent me to work in eight western states. It was tremendously rewarding work, and she gave me the confidence that I could make a meager living as a historian. I respect her even more because she realized that I needed to continue my path in graduate school and helped me transition back to Portland State. In the field, I had the pleasure of working with and getting to know, Jeff Van Pelt of the Confederated Tribes of the Umatilla Indian Reservation. With a firm but supportive hand, Jeff made sure that I always remembered that the Columbia River was aboriginal ceded territory, not a gift from the United States, and that tribes reserved their reservation lands. Thanks to all the past field crews for sharing ideas and inspiring my passion for protecting the past.

In the midst of this thesis, I was fortunate to have conversations with Johnson Meninick and Noah Oliver of the Yakama Nation's Cultural Resources Program. Johnson was both welcoming and firm that I not write this thesis for my personal gain. I continue to reflect on my conversation with him and vow to make this thesis and my sources available to Columbia River Indians in any way they find useful. Linda Long at the University of Oregon Archives and Special Collections was continuously helpful as I put together the puzzle of Wilson Charley and James James. With the assistance of an Oregon Heritage Fellowship Grant, I was able to digitize all of Charley's letters and fund numerous research trips. The fellowship also allowed me to present excerpts of this thesis at the Western History Association Annual Conference, American Association for Environmental History Conference, and the Graduate Student Environmental Arts and 
Humanities Conference at Oregon State University. At these meetings, many scholars provided feedback and encouragement. Further, I was blessed to be on panels with sharp and driven scholars specializing in similar topics to my own.

I owe tremendous thanks to my writing group partners: Melissa Lang, Taylor Rose, Katherine Nelson, Ryan Wisnor, Joshua Ross, Alecia Giombolini, Jo Ogden, and Katy Barber. I will forever cherish the long drives to Eugene and my ride buddies Melissa Lang and Justin Vipperman. All of these fine people kept me writing and were supportive throughout graduate school. I will miss the pots of coffee, potlucks, and conversations outside the library. I look forward to seeing all their future successes. I am thankful to anthropology professors Doug Wilson and Shelby Anderson for their influence how I understand conservation and cultural resource management. I owe so much to all the teachers, professors, and librarians that believed in me. Back in 2003, I was a part-time student at Linn Benton Community College and Michele Wilson, my instructor in a survey course called Native North Americans, refused to accept my cobbled-together paper. She pushed me to revise it and assured me, "you can do better." I could write an entire manifesto on all the inspiring teachers in my life. Thank you Michele and all my past teachers and professors for pushing me!

I also asked a great deal of my friends outside of school. Matt Sims, James Krzmarzick, Tariq Spence, Brian Myers, Jessica Anderson, and Emilie McMahon were all at times a sounding board, proofreader, critic, and constant loving, intelligent friends. My incredibly supportive family, Jan, Helen, and Sarah, both nurtured a love and respect for the past, as well as my crazy dream to be a historian. Lastly, I owe the most to my 
loving wife, Rehanah Spence. Rehanah has been my friend since high school and my life partner for over a decade. She, by far, has sat through more of my verbal "thoughts," endured miles of hikes and walks dominated by me talking about "research," and read countless drafts. Throughout all of it, she remained positive and supportive. She possesses an intellectual strength, creative passion, and kind heart like no other. Without her support, I would have never left Corvallis, let alone entered graduate school. 


\section{Table of Contents}

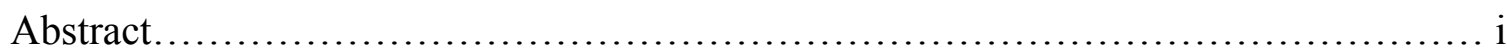

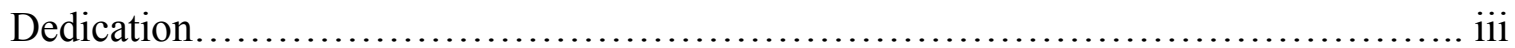

Acknowledgments...................................................... iv

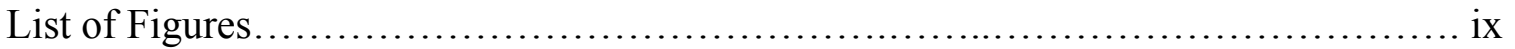

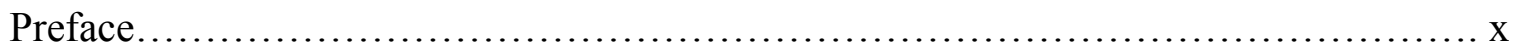

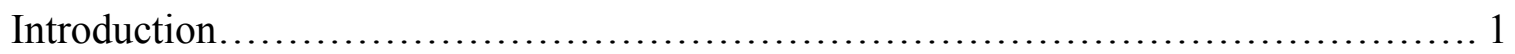

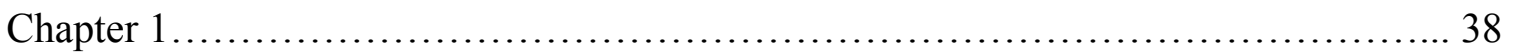

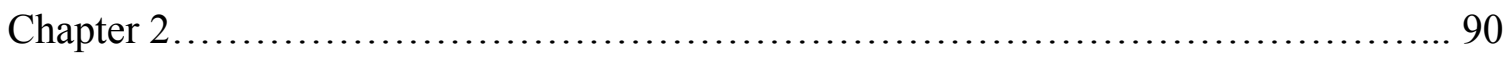

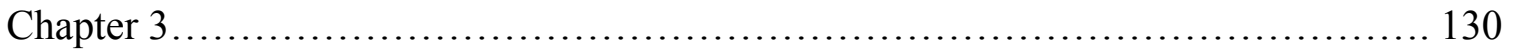

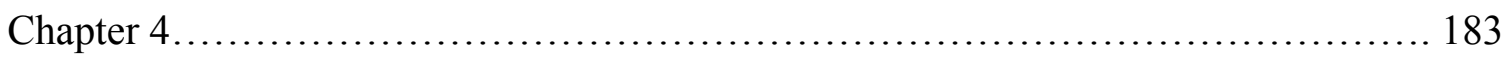

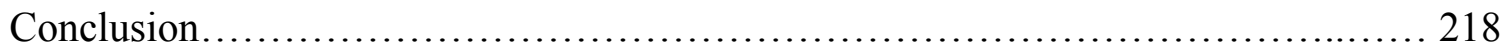

Bibliography........................................................ 229

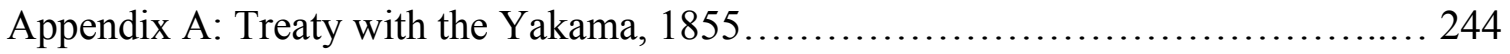




\section{List of Figures}

Figure 1: (p. xiv) Map of Wilson Charley's frequented places. Map by Rehanah Spence.

Figure 2: (p. 2) Wilson Charley with a 61-pound Chinook salmon he caught at Cascade Rapids. Image from: James J. James Papers, University of Oregon Special Collections, Eugene, Oregon.

Figure 3 (p. 2) Wilson Charley's home on the Yakama Indian Reservation where he did a majority of his letter writing. Image from: James J. James Papers, University of Oregon Special Collections, Eugene, Oregon.

Figure 4: (p. 39) Russell Lee photographed Native Americans fishing at Celilo Falls in 1941. The scaffolds and locations were the property of select fishing families and the open and closed seasons regulated by strict cultural customs. Image from the Library of Congress Prints and Photographs Division.

Figure 5: (p. 40) Russell Lee photograph of Native Americans fishing at Celilo. Image from the Library of Congress Prints and Photographs Division.

Figure 6: (p. 40) Russell Lee photograph of Native Americans fishing at Celilo with an example of the catch. Image from the Library of Congress Prints and Photographs Division.

Figure 7: (p. 92) Wilson Charley on the title page of this Man's Life article. He hoped it would garner non-native support for his fight by framing the destruction of Celilo as a threat to American democracy. From the personal collection of magazine collector Robert Deis.

Figure 8: (p. 93) Photographer Ben Maxwell captured the construction at The Dalles Dam in the spring of 1954, with only the initial pylon footings viable. Image from the Ben Maxwell Collection, Salem Public Library, Salem, Oregon.

Figure 9: (p. 129) Photographer Ben Maxwell photographed the construction of The Dalles Dam in September of 1954. Compared to figure 8, the construction had progressed rapidly over the summer. Image from the Ben Maxwell Collection, Salem Public Library, Salem, Oregon.

Figure 10 (p. 185) Photographer Ben Maxwell captured The Dalles Dam in 1958. Wilson Charley's fishing shed and the Lone Pine Indian camp are front and center in the foreground. Image from the Ben Maxwell Collection, Salem Public Library, Salem, Oregon. 


\section{Preface}

I remember the first time I saw The Dalles Dam. I was eight years old. I was with my granddad as he piloted his airplane, a Fairchild $24 \mathrm{~W}$, which he had purchased on his salary building dams as an electrical engineer for the California Oregon Power Company. High above the Columbia River, he pointed out The Dalles Dam on the horizon as we cruised up the river at 8,000 feet on our way to an airshow in Yakima, Washington. I looked down in awe as I watched the water cascade over the spillway and the barges navigate the lock. My granddad had retired after a successful career engineering numerous hydroelectric facilities throughout the Northwest and had championed the clean, abundant, and inexpensive cost of hydroelectric power.

I had a glorious childhood, but I did not understand that The Dalles Dam levied the cost unevenly onto Columbia River Indians. It took many more years to know that the dam I was admiring flooded Celilo Falls: one of oldest continuously inhabited sites in North America. I only knew that my granddad would circle my house in his airplane and take me flying to see all the wonders of the Northwest. It was from his background as an engineer and from this perspective at 8,000 feet that he told me the victorious story of electrifying the Columbia Basin and building a river shipping channel that reportedly brought prosperity to the region. I sat in his airplane, an artifact of that prosperity and traced the wires from the dam across the region. I loved every moment of it. His engineering schematics had helped built a vast electrical grid that produces a surplus of energy and wealth. 
Studying history and working four years as an archaeological technician on the same grounds I had flown over as a child changed how I see the world—as well as myself. I not only learned to contextualize my granddad's work, but I also came to realize and come to terms with just how privileged my childhood had been. Few, I have learned, grew up seeing the Columbia River riding in an airplane. On numerous occasions, I worked with tribal representatives on archaeological investigations who had profoundly different life experiences than me. They pushed me to think beyond what I knew —or what I thought I knew_about the past and helped me see my privilege.

At times, I have felt uncomfortable writing a history of an Indigenous leader who was part of a culture I know so little. While I am not Native American and do not speak for any tribal nation, I have come to realize that this story is also about non-natives like myself and our ancestors who ignored Native leaders like Wilson Charley. Through the letters of Wilson Charley, a man most will never have heard of, I have come to understand, in a very personal way, how so many were left worse off by The Dalles Dam. Through my analysis of his letters, readers will begin to understand and empathize with one Native American individual who wanted to protect his ancestral lifeway and landscape. The letters allow us to understand various cultural differences, and just as importantly, see shared values and ideas.

Like many in the region, I love making trips to the Columbia River Gorge. It is a stunning place. I encounter people like my former self who are unaware that Indigenous fishing families are still very active on the river. The presence of large dams and silent rapids seems to distract my fellow recreationalists from feeling the pain and seeing the 
persistence of Native American fishing families. In fact, many of these Native families are at the forefront of protecting the land, air, water, and fish not only for themselves but also for us all. At minimum we owe them acknowledgment and thanks.

The following thesis attempts to present a story about one man who, like so many other Indigenous people in the Columbia Basin, did not experience the same prosperity as myself and so many others. I understand that this thesis will not correct the real losses and deep pain Columbia River Indians have felt, and will continue to feel, from The Dallas Dam. For the majority of us who are not part of the Northwest's Indigenous communities, however, it is our responsibility to know what our ancestors did and, in this case, did not do when Native leaders asked for help and advised caution. In one way or another, we are all part of this story, and as I have come to learn, my privileged life has come at a real cost to real people.

As my undergraduate history professor Bill Lang told me, anyone who uses a light switch in this region is involved with the Columbia River dams. It is an observation I continue to repeat to others, and the story I have tried to present here relates to me and anyone in the Northwest who touches a light switch. On a global scale, it serves cautionary lessons from the history of colonialism and environmentalism. Non-natives, like myself, need to go beyond understanding, go beyond being allies; we need to actively support Indigenous leaders today in ways they find useful and needed. From the active debates over fossil fuel and coal transport in the Columbia Gorge to the Dakota Access Pipeline, which threatens the Standing Rock Sioux's sacred burials and waters, Native American leaders nationwide are leading fights to protect rivers for us all. While I 
do not speak on behalf of any tribe or Native American advocacy group, I acknowledge the environmental inequities of my contemporaries and hope that this history will better contextualize what is at stake today. As you flip the light switch, I hope you acknowledge the human costs of that convenience. 

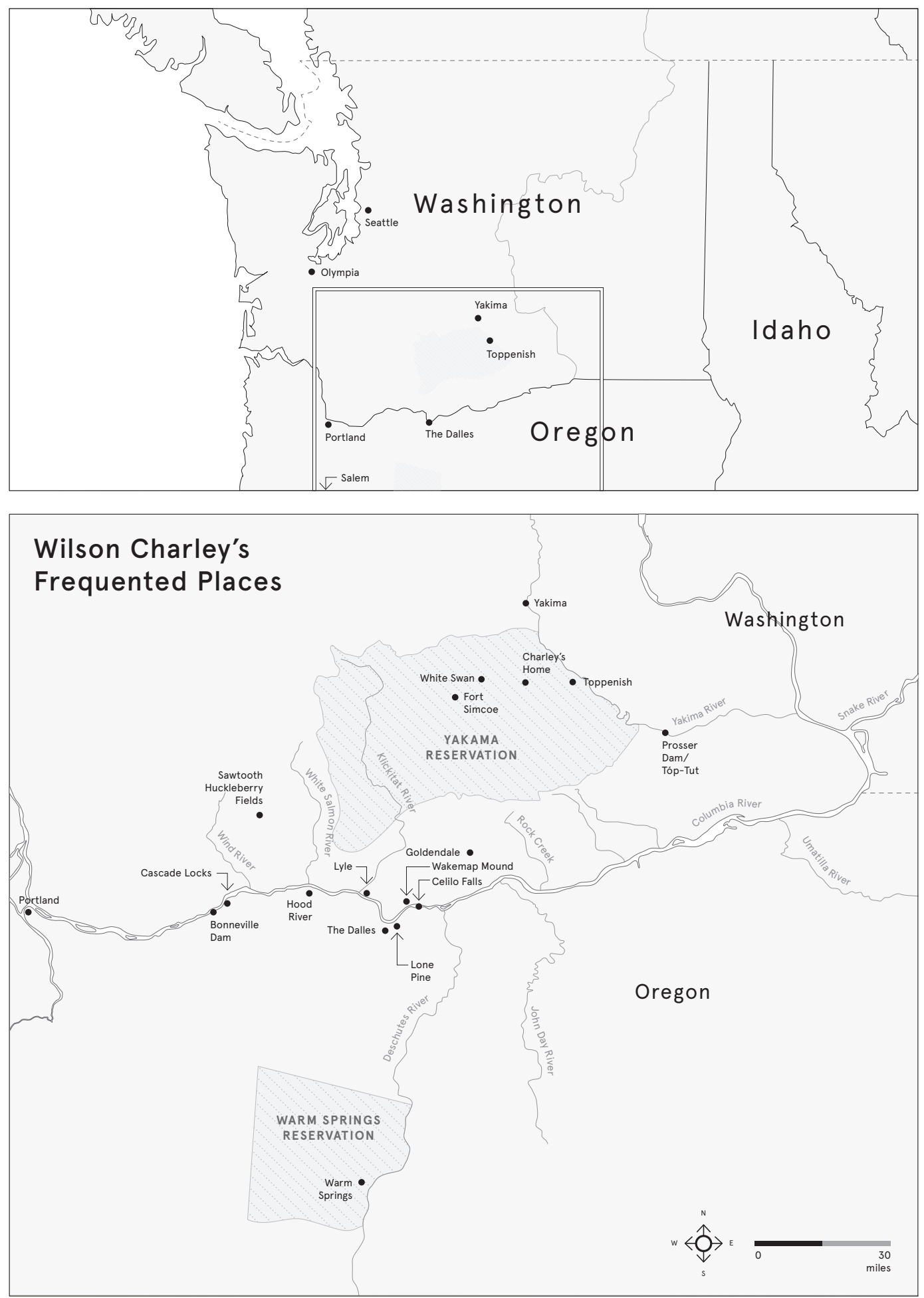

Figure 1: Map of Wilson Charley's frequented places. Map by Rehanah Spence. 


\section{Introduction}

Wilson Charley's fingers hovered over the keys of the typewriter as he contemplated his next sentence. After several days of fishing on the Columbia River, Charley had returned to his modest home off Route 1 on the Yakama Indian Reservation in central Washington. ${ }^{1}$ A leader in the local Native fishing community, Charley had developed several different strategies to resist aggressive non-native fishermen and regulatory officials, which were trying to nullify Columbia River Indians' fishing rights. ${ }^{2}$ Charley understood that putting his ideas to paper through letter writing could bring in support from his Indigenous community as well as activate sympathetic non-natives outside the reservation. The son of Jobe Charley, a powerful Columbia River Indian and rodeo star, Wilson Charley was more than a Native fisherman, he was an elected member of the Yakama Nation Tribal Council and former Chairman of the intertribal Celilo Fish Committee. In 1855, his great grandfather, along with other leaders, had reserved the "right of taking fish at all usual and accustomed places, in common with the citizens of

\footnotetext{
${ }^{1}$ Honoring the original spelling in the 1855 treaty, the Confederated Tribes and Bands of Yakama Indian Nation officially recognized the spelling "Yakama" in 1992. I use their preferred spelling, except in quotes or in cases that refer to the river, county, and city of the same name but spelled "Yakima." For the full text of the Treaty with the Yakama, 1855, see Appendix A.

2 Throughout this thesis, I use the terms Indian, American Indian, Native, Native American, and

2 Throughout this thesis, I use the terms Indian, American Indian, Native, Native American, and Indigenous to refer generally to aboriginal peoples. I try to refer to specific village, tribal, or family identities as much as possible, also using Andrew Fisher's term Columbia River Indian for the people living and fishing off reservation from Cascade Locks to the Hanford Reach. See, Andrew H. Fisher, Shadow Tribe: The Making of Columbia River Indian Identity (Seattle: University of Washington Press, 2010), 254 n.4.
} 


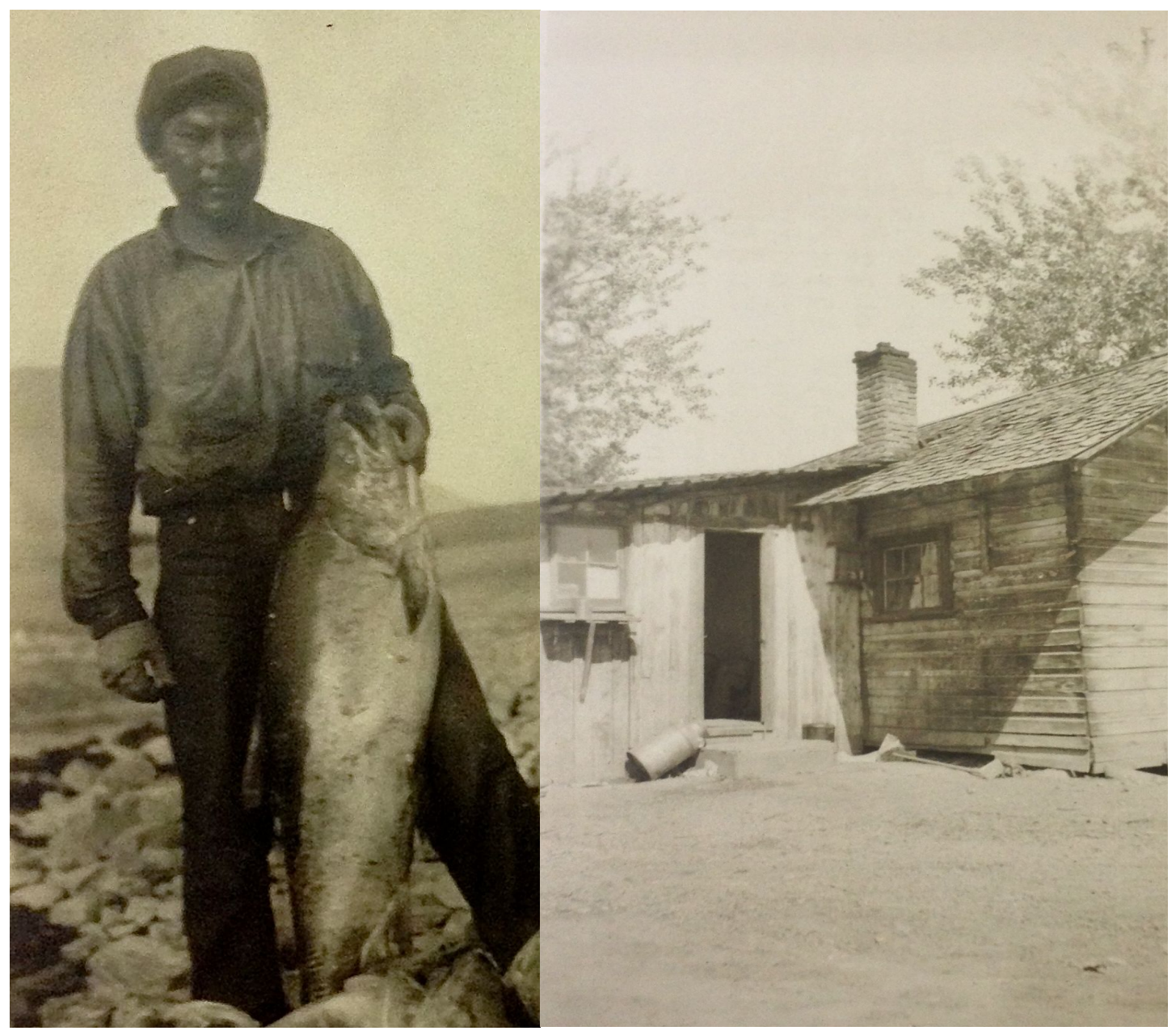

Figure 2 (left): Wilson Charley with a 61-pound Chinook salmon he caught at Cascade Rapids. Image from: James J. James Papers, University of Oregon Special Collections, Eugene, Oregon.

Figure 3 (right): Wilson Charley's home on the Yakama Indian Reservation where he did a majority of his letter writing. Image from: James J. James Papers, University of Oregon Special Collections, Eugene, Oregon. 
the Territory," when the United States ratified the Yakama Treaty of 1855. However, for Wilson Charley's entire life, racist and bureaucratic impediments restricted him as a leader and as a fisherman. He feared the Bureau of Indian Affairs censored his mail and that the press would dismiss him for simply being an Indian man with opinions on how to manage the Columbia River fisheries. ${ }^{3}$ By the 1950s, the situation became ever more complicated as the Army Corps of Engineers (ACOE) proposed a new dam at The Dalles which would completely inundate Celilo Falls and disproportionately affect his and other Native's lifeway.

Celilo Falls was a place of great spiritual, economic, and cultural importance to Indigenous people for millennia. Today you can only see Celilo Falls in pictures; the channeled basalt rocks remain under the slackwater pool of Lake Celilo. In 1957, The Dalles Dam, a massive L-Shaped concrete and steel structure flooded Celilo Falls as well as many other prime fishing locations like the Long Narrows, Three Mile Rapids, and Big Eddy. At Celilo Village, a small place of about 100 residents tucked up next to the towering basalt cliffs of the eastern Columbia River Gorge, there is no farmland, neither a place to raise livestock, nor a promising industrial site. However, uninterrupted prosperity existed here for over 10,000 years as the residents of this village fished the river, exchanged goods, and formed extensive kinship and trade networks to communities

\footnotetext{
3 Wilson Charley to James James, March 6, 1954, folder 43, box 1, James James Papers, AX 553, University of Oregon Archives and Special Collections, Eugene Oregon (hereinafter JJP).
} 
throughout the continent. These places represented more than an economic hub for Indigenous peoples; they were deeply spiritual and central to their cultural identity. Historian William Lang writes, "specific fishing spots used by Native fishers carried names that described physical characteristics of each location, referred to their mythical origins, and identified them as owned or controlled by specific families." Thus, the wooden scaffolds, cable cars, and drying sheds of Celilo Falls and The Dalles reach were socially and physically constructed places that reflected a complex nexus of technological adaptation, ecological knowledge, and cultural practices embedded in physical place. ${ }^{4}$ Given the significance of Celilo Falls, it is not surprising that Native Americans resisted The Dalles Dam. Charley pleaded for help from the Bureau of Indian Affairs, but the agency proved ineffective. ${ }^{5}$ Recognizing that a coalition of non-natives might help, he took matters into his own hands and began writing to others outside the BIA. Suddenly, inspiration hit, and he hammered out the next line, "I am one of that Yakima Nation, what I do is for the whole Nation, both Indian and White races." 6 With a force of determination, Charley's fingers found each key, struck it, and put his ideas and actions

\footnotetext{
${ }^{4}$ Virginia L, Butler and Jim E O'Connor. "9000 Years of Salmon Fishing on the Columbia River, North America." Quaternary Research 62, no. 1 (July 2004): 1-8; Virginia L. Butler, "Natural Versus Cultural Salmonid Remains: Origin of The Dalles Roadcut Bones, Columbia River, Oregon, U.S.A.” Journal of Archaeological Science, 20, no. 1 (January 1993): 1-24; William L. Lang, "The Sense of Place and Environmental History" in Dale D. Goble and Paul W. Hirt, eds. Northwest Lands, Northwest Peoples: Readings in Environmental History, (Seattle: University of Washington Press, 1999) 84-85.

${ }^{5}$ For an excellent and fair history of the Bureau of Indian Affairs see, Cathleen D. Cahill, Federal Fathers and Mothers: A Social History of the United States Indian Service, 1869-1933, (Chapel Hill: University of North Carolina Press, 2011).

${ }^{6}$ Charley to James, Oct. 14, 1954, folder 42, box 1, JJP.
} 
to paper. Framing his work first as an individual, then as a tribal member, then as a citizen of the United States, Charley aimed to uphold the protections his ancestors established in the 1855 Yakama Nation Treaty, not only for himself but also for the health and welfare of the entire United States. Through his typewriter, Charley alerted others that building The Dalles Dam would do more than flood some fishing grounds: Building the dam violated the sovereign protections his ancestors and U.S. representatives agreed to nearly one hundred years earlier in a treaty between two sovereign nations. Presenting himself as an elected leader of the Yakama Nation as well as a citizen of the United States, Charley sought to persuade U.S. citizens, planners, engineers, and scientists that American Indian people had their own dreams and were perfectly capable of managing their own affairs and resources. Trying to negotiate a "third space sovereignty," a conceptual borderland between these two sovereign nations, Charley hoped that U.S. leaders would acknowledge Native's intellect and allow Natives a seat at the table in planning the future of the river. ${ }^{7}$

Figuratively speaking, Charley and other Columbia River Indians had been in an ongoing game of poker with the United States over Native fishing rights. Through past cases, he understood that risking the treaty in federal court was a bold move. Given the rhetoric of technological optimism and the termination of federal supervision for Native

\footnotetext{
${ }^{7}$ Kevin Bruyneel, The Third Space of Sovereignty: The Postcolonial Politics of U.S.-Indigenous Relations (Minneapolis: University Of Minnesota Press, 2007), xvii.
} 
American tribes in the 1940s and 1950s, Charley realized that attempting to take the treaty to court over The Dalles Dam was too risky. Instead, Charley played a different hand; trying other strategies like personal claims, direct political appeals, and forging environmental alliances with urban non-natives to protect the treaty and his fishing rights. While his strategies failed in stopping the dam, there were important lessons learned. Eventually, the political climate shifted, and Charley's successors played their hand taking the treaty to court where they received a lasting decision in 1969. Thus, Charley's work is a significant, and heretofore undocumented, component of this larger struggle to uphold the treaty-protected right to fish and is an important middle chapter in the larger saga of Pacific Northwest fishing rights.

Through his letters, analyzed here for the first time, it is clear that Wilson Charley formulated calculated strategies to resist the construction of The Dalles Dam, the political ideology of termination, and state curtailment of Native fishing rights. This study is important because it places Indigenous actors on a twentieth-century Columbia River while demonstrating that they played active roles in the protest and management of areas affected by The Dalles Dam. Charley's letters give voice to a historically marginalized perspective often absent in the extant records of federal agencies, government reports, and press coverage. His words further illuminate an overlooked period in American Indian history between the end of the Indian New Deal in the 1930s and 1940s and the 
rise of the American Indian Movement and pan-Indian activism of the 1960s and 1970s. ${ }^{8}$ It challenges the widely held myth that Indigenous resource ownership was a primitive commons frozen in temporal stasis - a myth common throughout the twentieth century, and, even to this day. Moreover, this Indigenous-centered, place-based approach illuminates the social and physical construction of places that are much more complicated than they appear from the outside. Instead, Charley incorporated and redefined the terms often used against him to ensure that no matter how the river changed, his descendants would continue to benefit from the protections established in the 1855 treaty.

In particular, I argue that Charley used the language and ideas of conservation, itself a prequel idea to environmental movement of the 1960s and 1970s, to confront the misunderstanding that Columbia River Indians' treaty rights were rigid and static.

Charley's solutions could be as simple formulating Indigenous fisheries codes, or more complex plans to form Native fisheries cooperatives, build cold storage facilities, and set commercial price standards. Employing the term conservation, Charley presented rational, technologically adaptive, and Indigenous-centered solutions that sought to uphold the treaty's sovereign protections into the future.

\footnotetext{
8 Two excellent histories focused on the Confederated Tribes of the Colville Reservation effectively bridge this gap and have been particularly helpful. Laurie Arnold, Bartering with the Bones of Their Dead: The Colville Confederated Tribes and Termination (Seattle: University of Washington Press, 2012); Lawney L. Reyes, White Grizzly Bear's Legacy: Learning to Be Indian (Seattle: University of Washington Press, 2002).
} 
The forces that Charley resisted, and the unexpected tools he used to do it, were complex. In his effort to protect his fishing rights and stop The Dalles Dam, Charley engaged with national leaders in the conservation community about the role of federal regulation on public lands. Reading issues of proto-environmental publications, like Nature Magazine, he further developed his views regarding conservation, scientific management of fisheries, and tribal consultation in archeological investigations. Reaching out to nearly every organization he came across, Charley developed highpowered allies and enemies. Articulating an environmental consciousness, his interests easily dovetailed with proto-environmental groups like the Wilderness Society, who were advocating for national monuments to protect public lands from dams, drilling, and industrialism.

Charley's letters demonstrate that he was ahead of his time. He articulated many of his ideas in the 1950s, but they did not take hold for decades. Despite their advocacy for protecting landscapes, resources, and non-human nature, the various conservation groups Charley sought as partners ignored his pleas for help. This is mainly because, in the twentieth century, most Native Americans faced essentialist generalizations that viewed their reserved rights as artifacts of the past. In this highly racialized view, treaties belonged in movies and histories of early interactions between Natives and European Americans, not in contemporary culture. Non-native society validated Native ideas only when they fit non-natives romantic ideas of Hollywood Indians, which non-natives 
erroneously viewed as timeless and antithetically modern. This stereotype, itself a tool in an ongoing colonial project, aimed to assimilate Native Americans and freeze Native culture in a metaphorical glass case. ${ }^{9}$ Further, Charley's story complicates the common mythology of 1950 s conformity because he challenged the inevitability narrative of massive federal dam building projects. He understood that average people had the right to stand up and resist the federal government's plans. In Charley's opinion, these projects did not bring equal profits to all and were themselves artifacts of the military industrial complex.

Charley's letters also complicate several erroneous assumptions: that environmentalism was only the pursuit of elite white interests; that traditionalism was a prerequisite of indigeneity; that environmental change negated treaty rights; and that Natives did not resist the building of The Dalles Dam. Thus, Charley's story makes several important contributions to the fields of Native American history, the history of the Pacific Northwest, environmental history, and the history of colonialism.

As a Native leader, Charley was not an anomaly. His leadership was that of an "unexpected Indian." Coined by the great Native American historian Philip Deloria, "unexpected" embodies Native resistance and empowerment. Charley defied the colonial society's stereotype of an Indian leader; equipped with his typewriter, a one-ton Ford

\footnotetext{
9 Patrick Wolfe, "Land, Labor, and Difference: Elementary Structures of Race," The American Historical Review 106, no. 3 (2001): 866-905; Donald Fixico, The American Indian Mind in a Linear World: American Indian Studies and Traditional Knowledge (New York: Routledge, 2003).
} 
pick-up, a fedora, and a command of contemporary policy and politics, he looked and behaved in ways that were unexpected in the eyes of non-natives. Viewing Charley's leadership as unexpected, rather than anomalous, I join Deloria in both acknowledging Natives' resistance to colonial expectations and presenting a narrative that shows how Native people "engaged the same forces of modernization that were making non-Indians reevaluate their own expectation of themselves and their society." Further, Deloria encourages readers to "distinguish between the anomalous, which reinforces expectations, and the unexpected, which resists categorization, and thereby, questions expectation itself."10

Early histories of North America reinforced a colonial view that Native Americans were obstacles in manifest destiny. Many of these works, especially on the American West, incorporated Native actors into the narrative, but historians often portrayed Native Americans as a unified or monolithic racial group without individual agency. Even when early historians authored narratives with individual American Indian actors, they did so from the perspective of the tragic hero. Faced with limited sources, these early histories were fraught with ethnocentric judgments and cultural misunderstandings. Often these historians wrote about American Indians in the past tense, implying they had vanished or were no more, part of a subtle but direct project to

\footnotetext{
10 Philip Joseph Deloria, Indians in Unexpected Places (Lawrence: University Press of Kansas, 2004), 114 esp. 6 and 11 .
} 
assimilate and erase their presence as complex, distinct, and diverse societies. Mirroring this larger trend in the Pacific Northwest, the earliest histories of the Columbia River mentioned Native people at Celilo Falls but did so in simplified terms related to trade and as obstacles in American ambition in the West. Early twentieth-century histories at best romanticize Natives, and at worst, consider them bygone figures on the Columbia, despite Natives' continued persistence along the river - a trend with a few exceptions, which continued for decades. ${ }^{11}$

This thesis utilizes literature from the fields of anthropology, American Indian history, ethnohistory, environmental history, and incorporates emic perspectives articulated by Indigenous writers themselves. I join a large cohort of scholars that are addressing a long disparity in the history of Indigenous peoples, which, too often has generalized Natives as collectivist thinkers. Among its gross simplification and myriad issues, this view has ignored Native's significant intellectual contributions-especially to themes like to environmentalism, social justice, sovereignty, and scientific management.

\footnotetext{
11 Recognizing that historians continue to discuss the role of Frederick Jackson Turner's "Frontier Thesis" in how we conceptualize the history of the West, it would be negligent to not to cite it. However, I have intentionally decided to leave Turner and the preceding booster historians of the Pacific Northwest out of the main text to preference the ongoing project for more Native centered histories. Frederick Jackson Turner, American Historical Association, and State Historical Society of Wisconsin, The Significance of the Frontier in American History .... (Form Proceedings of the Forty-First Annual Meeting of the State Historical Society of Wisconsin). (American Historical Association, 1894); Joseph Gaston, Portland, Oregon, Its History and Builders: In Connection with the Antecedent Explorations, Discoveries, and Movements of the Pioneers That Selected the Site for the Great City of the Pacific (Chicago: S.J. Clarke Publishing Company, 1911); Dorothy O. Johansen, Empire of the Columbia: A History of the Pacific Northwest, 2 edition (New York: Harper Collins, 1967).
} 
Of course, Native Americans have had their own histories and historical sources independent from the European-American definition of documentary sources. Yet, the different ways anthropologists and historians interpret these sources presents potential points of division. It also points to the possibility for fruitful interdisciplinary collaboration. Physical objects, landscapes, writings, language, oral tradition, ceremony, dance, and other rituals are all sources, or "cultural products" as some anthropologists call them, societies use to transmit knowledge and story. Anthropologists, like Clifford Geertz, sought to interpret these cultural products as texts and thereby write a thick description of cultures. Historians, like James Axtell, utilized similar methods in an attempt to "fill in" the precontact past in a narrative form called Ethnohistory. Beginning with the work of Axtell and Geertz in the late 1970s, the scholars of history, ethnohistory, and anthropology have produced a vast body of work on the pre and post contact history of Native Americans that aims to incorporate sources not often found in the traditional archive.

At the same time, critics of anthropological and ethnohistorical studies have exposed their largely etic perspective, meaning that they are oriented toward the viewpoint of an observer outside the culture. In 1969, Vine Deloria Jr.'s Custer Died for Your Sins called for an emic, or cultural insider's, viewpoint to recenter a Native paradigm in American Indian history. Deloria noted that past Native American histories, while factual and accurate, were "not really about Indians." Further, he argued that these 
historians "twist Indian reality into a picture which is hard to understand and consequently greatly in error." American Indian history and ethnohistory both seek to present an Indigenous perspective in narrative form but their methods differ. Generally, ethnohistory borrows tools from anthropology and political economy to mix-in historical chronology with the concept of culture; it also seeks to analyze the agency of all historical parties. American Indian history, as articulated by historians Susan A. Miller and Ned Blackhawk, differs in that shifts the analytical lens "to produce Indian history from an Indian perspective.” Native-centered paradigms seek to accurately and fairly portray Native historical actors in ways useful for contemporary Indigenous people. Further, as Raymond J. DeMallie notes, both disciplines share the goal of "understanding the past in its own terms, of reading the record of the past in a manner that as fully and very similarly as possible represents events as they were perceived by the actors." Seeing the merits of both sub-fields, I borrow methods from ethnohistory and American Indian history in my analysis of Charley's letters. ${ }^{12}$

12 Clifford Geertz, "Deep Play: Notes on the Balinese Cockfight," Daedalus 101, no. 1 (1972): 1-37; James Axtell, "Ethnohistory: An Historian's Viewpoint," Ethnohistory 26, no. 1 (1979); James Axtell, Natives and Newcomers: The Cultural Origins of North America (New York: Oxford University Press, 2000); William Roseberry, Anthropologies and Histories: Essays in Culture, History, and Political Economy (New Brunswick, N.J.: Rutgers University Press, 1989); Vine Deloria Jr., Custer Died for Your Sins, an Indian Manifesto, (New York: Macmillan 1969), esp. 16; Ned Blackhawk, "Currents in North American Indian Historiography," The Western Historical Quarterly 42, no. 3 (October 2011): 319-24; Susan A. Miller, "Native America Writes Back: The Origin of the Indigenous Paradigm in Historiography," Wicazo Sa Review 23, no. 2 (October 1, 2008): 9-28; Raymond J. DeMallie, “"These Have No Ears': Narrative and the Ethnohistorical Method," Ethnohistory 40, no. 4 (October 1, 1993): 515-38. 
On the regional level, meaning the Columbia River Basin, several ethnohistories have featured Indigenous leaders. These works, while addressing missing Native American perspectives, still relied on colonial sources. Focused largely on contact and treaty era figures, these works do not necessarily present the direct agency of Native leaders and are more counter-narratives to extant episodes of U.S. conquest. Robert H. Ruby and John R. Brown's prolific works include Half Sun on the Columbia (1965), Cayuse Indians (1972), and Dreamer Prophets (1989), which cover the work of Chief Moses, a Cayuse Indian side of the Whitman killings of 1847, and the proliferation of the Ghost Dance movement led by Smohalla on the Columbia Plateau respectively. James P. Ronda's Lewis and Clark Among the Indians (1984) is squarely an ethnohistory. Using the expedition journals, archaeological reports, and ethnographic observations, Rhonda tells the story of the U.S. expedition filtered through a Native perspective. Robert Boyd's People of the Dalles (1996) tells the story of the Chinookan and Sahaptin-speaking peoples at The Dalles' Wascopam Mission through the papers of the Methodist missionaries. Even Elliott West's Last Indian War (2011), which covers Chief Joseph's run from the U.S. Army, is largely about U.S. military history with a more balanced view toward the Native perspective. While these histories begin to address missing Native American perspectives, they still lack Native-centered narratives and remain thematically linked to the history of the American West instead of American Indian history. ${ }^{13}$ 
The easiest way to have a Native-centered history is when Natives write about themselves. While Wilson Charley never personally published any material, there is a well-established literature of American Indians writing about themselves - although it is unknown if Charley ever read any of it. At the turn of the twentieth century, the writings of Indigenous intellectuals, such as Luther Standing Bear (Land of the Spotted Eagle, 1933) Carlos Montezuma (Wassaja, 1916 - 1922), Charles Eastman (Indian Boyhood, 1902) and D'Arcy McNickle (The Surrounded, 1936), began to help non-native readers fathom the depths of American Indians' historical knowledge and cultural perspective. At the same time, these works also began to challenge the dominant historical narrative of Natives as passive subjects of American conquest - providing other Indigenous writers a model to follow.

Writing largely for educated non-native readers, these Indigenous writers were educated in either U.S. boarding schools and/or universities, and many worked for the Bureau of Indian Affairs or independent Native rights organizations. Ethnologists and early anthropologists, who sought to catalog and compare Indigenous cultures, further celebrated these auto-ethnographies because they provided such rich description of an

and Skolaskin (Norman: University of Oklahoma Press, 2002); Robert H. Ruby and John Arthur Brown, The Cayuse Indians: Imperial Tribesmen of Old Oregon (Norman: University of Oklahoma Press, 2005); Robert H. Ruby, Half-Sun on the Columbia: A Biography of Chief Moses (Norman: University of Oklahoma Press, 1995); Elliott West, The Last Indian War: The Nez Perce Story, (New York: Oxford University Press, 2011); James P. Ronda, Lewis and Clark among the Indians, (Lincoln: Bison Books, 2002); Robert Boyd, People of The Dalles: The Indians of Wascopam Mission (Lincoln: University of Nebraska Press, 2004). 
individual's life in the first few generations of contact. Anthropologists and historians have used these works as primary and secondary sources for a baseline in understanding cultural change. ${ }^{14}$

Prioritizing Wilson Charley's voice in direct quotes as much as possible, I present a narrative that responds to Vine Deloria Jr.'s call to keep American Indian history about Indians. However, I am a cultural outsider and interpret the significance of Charley's work from an etic view, using a variety of ethnographic sources and secondary works to contextualize Charley's actions in his time. Consulting the work of plateau ethnographers, I maintain a critical eye toward the anachronistic issues of divorcing culture from change over time. ${ }^{15}$ The works of Peter Nabokov and Donald Fixico have pushed me to recognize that cultural change is constant while also remaining open to non-linear ideas and interpretations of Charley's work. ${ }^{16}$

\footnotetext{
${ }^{14}$ D'Arcy McNickle, The Surrounded (Albuquerque: University of New Mexico Press, 1978); Luther Standing Bear, Land of the Spotted Eagle (Lincoln: University of Nebraska Press, 2006); Charles Alexander Eastman, Indian Boyhood (New York: McClure, Phillips, 1902); Peter Iverson, Carlos Montezuma and the Changing World of American Indians (Albuquerque: University of New Mexico Press, 1982); Robert Allen Warrior, "Reading American Indian Intellectual Traditions," World Literature Today 66, no. 2 (1992): 236-40.

15 Edward Sapir and Jeremiah Curtin, Wishram Texts (Leyden, Late E.J. Brill, 1909), http://archive.org/details/wishramtexts00sapirich; Eugene S Hunn and James Selam, Nch' $i$-Wána, "the Big River": Mid-Columbia Indians and Their Land (Seattle: University of Washington Press, 1990); Lillian A Ackerman, A Necessary Balance: Gender and Power among Indians of the Columbia Plateau (Norman: University of Oklahoma Press, 2003).

16 Peter Nabokov, A Forest of Time: American Indian Ways of History (New York: Cambridge University Press, 2002); Donald L. Fixico, Indian Resilience and Rebuilding: Indigenous Nations in the Modern American West (Tucson: University of Arizona Press, 2013); Ned Blackhawk, Violence over the Land: Indians and Empires in the Early American West (Cambridge: Harvard University Press, 2008).
} 
With a proliferation of historical sources in the nineteenth and twentieth centuries, I join a growing body of historical literature grounded in archival-based research that features Indigenous historical actors and positions their work as resistance to colonial hegemony. Part history, part biography, Peggy Brock's The Many Voyages of Arthur Wellington Clah (2011) uses one Tsimshian man's journal and letters to show how he navigated the changing social and political landscape of the early Canadian First Nations reservation system. Clah's journal covers the full complexity of the individual, and at times, readers see how he sometimes advanced his own personal desires over those of his own community. Gray Whaley's Oregon and the Collapse of Illahee (2010) traces the subtle but tactical ways in which Indigenous individuals vied for political and economic power in the midst of colonial incursions into the Pacific Northwest, forging new multiracial alliances and kinship networks. Paige Raibmon's Authentic Indians (2005) focuses on Indigenous performance and the layered meaning of authenticity. Raibmon shows how Indigenous migratory labor subtly incorporated traditional gatherings like the Potlatch, which were banned by colonial administrators, demonstrated Indigenous performances as both a way to cater to white tourism while at the same time maintaining prohibited cultural practices. Nicole Tonkovich presents individual Nez Perce tribal members' side to General Allotment Act on the reservation in The Allotment Plot (2012). Tonkovich argues that through "skillful resistance and negotiation, the Nez Perces effected the modification of allotment policies on the reservation, and...continued to exist as a 
sovereign body." These balanced works complicate the dominance of settler colonialism by showing the fluidity of Native responses and resistance to drastic changes in their societies-I aim to do the same in this thesis. ${ }^{17}$

At the same time, it would be a mistake not to position this thesis in the regional historiography of the salmon crisis and the Columbia River. By the 1990s, decades of hatcheries and restoration programs still had not returned salmon populations to their predam levels in the Columbia Basin. Richard White's concise and important book, The Organic Machine (1995), merged a sub-field of environmental history, which had largely focused on dam building and water-use in the West, to the common idea of human labor. White argues the dichotomies of Native and non-native and natural and man-made manipulations limit how we understand the Columbia River and prevent us from seeing the river today and in the past as a cultural construct, an "organic machine" which reflects both human and "unmade" qualities. For White, "nature can be known through labor," and his short chapters show how even after the proliferation of dams on the Columbia, society's fascination with hatcheries, population decline, and tribal court cases, all show how "salmon have demonstrated their power as they have diminished in numbers." A

\footnotetext{
${ }^{17}$ Peggy Brock, The Many Voyages of Arthur Wellington Clah: A Tsimshian Man on the Pacific Northwest Coast (Vancouver: University of British Columbia Press, 2011); Gray H. Whaley, Oregon and the Collapse of Illahee: U.S. Empire and the Transformation of an Indigenous World, 1792-1859, (Chapel Hill: University of North Carolina Press, 2010); Paige Raibmon, Authentic Indians: Episodes of Encounter from the Late-Nineteenth-Century Northwest Coast (Durham, N.C.: Duke University Press, 2005); Nicole Tonkovich, The Allotment Plot: Alice C. Fletcher, E. Jane Gay, and Nez Perce Survivance (Lincoln: University of Nebraska Press, 2012), esp. 5.
} 
biologist and not a historian, Jim Lichatowich's Salmon Without Rivers (1999), continues to break down the false human-nature dichotomy and argues that science alone cannot restore salmon populations. Instead, Lichatowich broadens how we see the dynamic of human-salmon interactions to include Native cultural expressions and history. Historian Jay Taylor's Making Salmon (1999) takes a similar trajectory, but Taylor grounds his work in historical empiricism and properly historicizes overfishing for its changing meanings over time. Further, Taylor balances his assessment of all the fishers, arguing that even "Indians had a greater impact on salmon than we assume, and the success of their fishery has far more significance than Edenic myths suggest." The idea that Natives did impact fish populations and that Indians developed and changed cultural practices over time is echoed by Douglas Dompier, a non-native fish biologist who worked for the Columbia Intertribal Fish Commission. His work, Fight of the Salmon People (2005) presents his own work with tribes and his realization that tribal practices and cultural traditions have connections, and sometimes analogs, to current scientific management efforts. All these works share a common struggle to recognize the millennial record of Indigenous stewardship, while also recognizing that Native fishers' lasting relationship with salmon and the river. ${ }^{18}$

\footnotetext{
18 Richard White, The Organic Machine the Remaking of the Columbia River (New York: Hill and Wang, 1996), esp. 91; James A. Lichatowich, Salmon Without Rivers: A History Of The Pacific Salmon Crisis, (Washington, D.C.: Island Press, 2001); Joseph E. Taylor III, Making Salmon: An Environmental History of the Northwest Fisheries Crisis (Seattle: University of Washington Press, 1999), esp. 13; Douglas W.
} 
Incorporating themes articulated by American Indian history, such as identity, resistance, and survival, a whole host of studies added Indigenous-centered narratives to the Columbia River salmon crisis. Roberta Ulrich's Empty Nets (1999) places Columbia River Indians at the center of resistance to Bonneville Dam and contextualizes Natives' ongoing struggle to secure in-lieu replacement fishing sites affected by other dams along the river. Ulrich's important book shows how individual families, not necessarily tribal governments, led the fight for in-lieu sites. Katrine Barber's powerful book, Death of Celilo Falls (2005), traces the negotiations between Native tribes and the U.S. Army Corps of Engineers during The Dalles Dam settlement. Keeping Native actors at the center of the story, Barber shows the irreconcilable gulf between the federal government's desire to build a dam for a prospective economic opportunity and the protection of Native sites with deep spiritual, cultural, and economic importance. Army Corps of Engineers and Congress confined the negotiations with tribal officials to the amount of settlement funds, not if the dam should be built or even how to reach a meaningful settlement. Her work not only shows that compensation was unjust, but that the influence of Celilo Falls has lived on through the work of Native people themselves. Andrew Fisher's important work, Shadow Tribe (2010), effectively outlines the complex interrelationships between tribal, traditional village/family, and pan Columbia River Indian identities. As Fisher shows, Columbia River Indian identity is complex and 
multilayered. In particular, Fisher shows that fishing sites were the private property of select families, who often had family members represented amongst tribes throughout the northwest. Thus, the actions of one fishing family might not reflect other fishing families of even the same tribe. These three scholars show how the dynamic between tribes and Native individuals is complex, and that taking a purely tribal or pan-Indian view is often overly simplistic. 19

The depth of individual and tribal perspectives has only begun to blossom as more Columbia River Indians write their own histories. Four important histories, written in the twenty-first century, finally presented Columbia River Indian history from emic perspective-looking from the inside out versus outside in. Allan Pinkham's Salmon and his People (1999) powerfully presents the stories of Nez Perce fishers remembering Celilo Falls. George Aguilar's When the River Ran Wild! (2005) is a history of his Kisht speaking family and their connection to culture embedded in the landscape of the Columbia River. The Confederated Tribes of the Umatilla Indian Reservation's innovative book, Wiyaxayxt Wiyaakaa'awn: As Days Go By (2006) presents tribal members' history "in their own terms and in their own ways," in tandem with nonnatives' historical perspectives. Finally, The Si'lalo Way (2006) presents a series of legal histories that feature Indigenous persistence, legalistic strategy, and the changing

${ }^{19}$ Roberta Ulrich, Empty Nets: Indians, Dams, and the Columbia River (Corvallis: Oregon State University Press, 2007); Katrine Barber, Death of Celilo Falls (Seattle: University of Washington Press, 2005); Fisher, Shadow Tribe; Barbara Leibhardt Wester, Land Divided by Law: The Yakama Indian Nation as Environmental History, 1840-1933 (New Orleans: Quid Pro, 2014). 
environment along the river. Additionally, it is one of the only published narratives

mentioning one of Wilson Charley's innovations: a large refrigeration warehouse proposed at Celilo Falls. ${ }^{20}$

This thesis also touches on concepts from the field of environmental history and complicates the trope of the "ecological Indian." Native Americans have and continue to face a simplistic trope of being at one, or harmoniously in tune with nature. The work of Shepard Krech, as well as the many scholars who critiqued his controversial work, The Ecological Indian (1999), opened my eyes to the dehumanizing trope of Native's de facto balance with nature and presented me a critical framework for critically analyzing Charley as a modern environmental leader. ${ }^{21}$ Scholars such as Marsha Weisiger, Khalil Anthony Johnson, Joshua L. Reid, Paul Nadasdy, and Keith Thor Carlson, Julie Cruikshank and John Fahey, have all written excellent histories that acknowledge Native traditional ecological knowledge, but also incorporate modernity, cultural, and environmental change, while at the same time keeping the narrative centered on

20 Dan Landeen and Allen Pinkham, Salmon and His People: Fish and Fishing in Nez Perce Culture, (Lewiston, Idaho: Confluence Press, 1999); George Aguilar, When the River Ran Wild!: Indian Traditions on the Mid-Columbia and the Warm Springs Reservation (Seattle: University of Washington Press, 2005); Jennifer Karson, Wiyaxayxt / Wiyaakaa'awn / As Days Go By: Our History, Our Land, Our People--The Cayuse, Umatilla, and Walla Walla (Seattle: University of Washington Press, 2006); Joseph C. Dupris, Kathleen S. Hill, and William H. Rodgers, The Si'lailo Way: Indians, Salmon, and Law on the Columbia River (Durham, N.C.: Carolina Academic Press, 2006).

${ }^{21}$ Shepard Krech, The Ecological Indian: Myth and History (New York: W.W. Norton, 1999); Brian Hosmer, Shepard Krech, and Judith Antell, Native Americans and the Environment: Perspectives on the Ecological Indian, ed. Michael E. Harkin and David Rich Lewis (Lincoln: University of Nebraska Press, 2007); Andrew C. Isenberg, The Destruction of the Bison: An Environmental History, 1750-1920 (New York: Cambridge University Press, 2001); Peter Iverson, When Indians Became Cowboys: Native Peoples and Cattle Ranching in the American West, (Norman: University of Oklahoma Press, 1994). 
Indigenous historical actors. These important studies are both Indigenous-centered histories while directly confronting the myth of the "Ecological Indian." Alternatively, they present a fair and balanced portrayal of Indigenous peoples' engagement with nature - often actions that reflect select cultural values and practices. In other words, they present Natives as rational human beings capable of individual agency in how they interact with, and affect change upon, their environments. ${ }^{22}$

However, hardly anyone in the 1950s would recognize the term “environmentalism," but by the 1960s, many would. Environmental historians Lincoln Bramwell, William Philpott, and Adam Rome all focus on the suburban centers of the 1950s as a critical genesis moment in the U.S. environmentalism. As they show, the rising popularity of the electrified suburban home and all its myriad consumables fostered an environmental consciousness among affluent white suburbanites. Through either vacation homes or the loss of green space adjacent to suburban expansion, suburbanites made the connection between the loss of wild and scenic landscapes and the consumption

\footnotetext{
22 Marsha L. Weisiger, Dreaming of Sheep in Navajo Country, (Seattle: University of Washington Press, 2009); Khalil Anthony Johnson Jr., "The Chinle Dog Shoots: Federal Governance and Grass-Roots Politics in Postwar Navajo Country," Pacific Historical Review 83, no. 1 (February 1, 2014): 92-129; Joshua L. Reid, The Sea Is My Country: The Maritime World of the Makahs (New Haven: Yale University Press, 2015); Paul Nadasdy, Hunters and Bureaucrats: Power, Knowledge, and Aboriginal-State Relations in the Southwest Yukon, (Vancouver, B.C.: University of British Columbia Press, 2005); Keith Thor Carlson, The Power of Place Problem of Time: Aboriginal Identity and Historical Consciousness in the Cauldron of Colonialism. (Toronto: University of Toronto Press, 2010); Julie Cruikshank, Life Lived Like a Story: Life Stories of Three Yukon Native Elders, (Lincoln: University of Nebraska Press, 1992); John Fahey, Saving the Reservation: Joe Garry and the Battle to Be Indian, (Seattle: University of Washington Press, 2015); Lionel Youst and William Seaburg, Coquelle Thompson, Athabaskan Witness: A Cultural Biography (Norman, University of Oklahoma Press, 2002); Lawney L. Reyes, White Grizzley Bear's Legacy: Learning to Be Indian (Seattle: University of Washington Press, 2002).
} 
in their own homes. ${ }^{23}$ The work of Roderick Nash, Hal Rothman, and Mark Harvey

complicate the history of environmentalism by connecting this suburban awaking to the

battle to preserve far away landscapes like Echo Park on the Colorado River.

Environmental historians Louis Warren, Carl Jacoby, William Cronon, and Richard

White convincingly expose the elite intellectual foundations in state simplification and

the environmental and conservation movements, which have not been uniform and tended

to benefit certain hunters and fishers over others. ${ }^{24}$ Charley's efforts to work with

Oregon's Senator Richard Neuberger and local suburban sportsmen's associations show

his strategic thinking and how he tried to connect Celilo to national environmental

movements such as Echo Park and various Sportsmen's Associations. ${ }^{25}$

Charley's work also makes a significant contribution to the legal history of Native

American fishing rights. He was not merely fighting to save fish; he was fighting to

23 Lincoln Bramwell, Wilderburbs: Communities on Nature's Edge (Seattle: University of Washington Press, 2014); Adam Rome, The Bulldozer in the Countryside: Suburban Sprawl and the Rise of American Environmentalism, (Cambridge: Cambridge University Press, 2001); William Philpott, Vacationland: Tourism and Environment in the Colorado High Country, (Seattle: University of Washington Press, 2013).

${ }^{24}$ Louis S. Warren, The Hunter's Game: Poachers and Conservationists in Twentieth-Century America (New Haven: Yale University Press, 1999); Karl Jacoby, Crimes against Nature: Squatters, Poachers, Thieves, and the Hidden History of American Conservation, (Berkeley: University of California Press, 2003); William Cronon, Uncommon Ground: Rethinking the Human Place in Nature (New York: W. W. Norton, 1996); Richard White, "American Environmental History: The Development of a New Historical Field," Pacific Historical Review 54, no. 3 (August 1, 1985): 297-335.

25 Roderick. Nash, Wilderness and the American Mind. (New Haven: Yale University Press, 1967); Mark W. T. Harvey, A Symbol of Wilderness: Echo Park and the American Conservation Movement (Seattle: University of Washington Press, 2000); Hal K. Rothman, The Greening of a Nation?: Environmentalism in the U.S. Since 1945 (Fort Worth, Tex.: Wadsworth, 1997); Mason Drukman, Wayne Morse: A Political Biography (Portland: Oregon Historical Society Press, 2004); William G. Robbins, Landscapes of Conflict: The Oregon Story, 1940-2000 (Seattle: University of Washington Press, 2009). 
protect tribal sovereignty and explicit treaty rights to fish. In the 1940s and 1950s, nonnative regulators had imposed conservation laws to curtail treaty-fishing rights. Charley responded by applying conservation in his own terms as he tried to build a powerful but simplified tribal regulatory structure to protect Native fishing families from federal and state authorities. My analysis of Charley fills an important gap in the historiography between the well-covered fishing rights trilogy cases of U.S. v. Taylor (1887), U.S. v. Winans (1905), and U.S. v. Seufert (1919) and the later violent arrests in fish-in movement and the subsequent Boldt and Belloni decisions of 1960s and 1970s, in U.S. v. Oregon (1969) and U.S. v. Washington (1974), respectively. Often, historians use the early cases as context for the former, which finally recognized Columbia River Indians right to fifty percent of the fish harvest annually in 1979. I contend that there is not a linear progression in the legal path to the Boldt decision. I consider Charley's involvement in several overlooked cases in the 1930s, 1940s, and 1950s as a part of the later success of the Boldt decision. ${ }^{26}$ Legal historians Barbara Leibhardt Wester, Alexandra Harmon, Charles Wilkinson, and Cole Harris trace the legal history of over one hundred years of Northwest fishing rights cases and show how individuals used multiple strategies to test the American legal system. Stephen Pevar's The Rights of Indians and Tribes and Father Francis Paul Prucha's Great Father are exceptional

${ }^{26}$ These cases are discussed in detail in many works, the most concise being, Fay G Cohen et al., Treaties on Trial: The Continuing Controversy over Northwest Indian Fishing Rights (Seattle: University of Washington Press, 1986); Alexandra Harmon, Power of Promises: Rethinking Indian Treaties in the Pacific Northwest (Seattle: University of Washington Press, 2008). 
resources in placing this study in a much broader context of American Indian legal history. ${ }^{27}$

I do not contest that higher profile fish-in movement and landmark Bolt and Belloni decisions are indeed the bedrock of current fishing rights law. Rather, I connect Charley's work to a colonial process of "unmaking Native spaces," a process whereby colonial legal systems recognize Indigenous sovereignty and seek to erode it through law. Using the same colonial legal systems, Indigenous leaders have long resisted this unmaking of Native space by taking their treaties to court. The high profile fish-in movement, best articulated in the work of Bradley Shreve, Charles Wilkinson, Fay Cohen, Sherry Smith, and Andrew Fisher, had important connections to Charley's failed strategies a decade earlier. ${ }^{28}$

27 Wester and Scheiber, Land Divided by Law; Alexandra Harmon, Indians in the Making: Ethnic Relations and Indian Identities around Puget Sound, (Berkeley: University of California Press, 2000); Charles F Wilkinson, et. al., Messages from Franks Landing: A Story of Salmon, Treaties, and the Indian Way (Seattle: University of Washington Press, 2005); Douglas C. Harris, Fish, Law, and Colonialism: The Legal Capture of Salmon in British Columbia, (Toronto: University of Toronto Press, 2001); Stephen Pevar, The Rights of Indians and Tribes (New York: Oxford University Press, 2012); Francis Paul Prucha, The Great Father: The United States Government and the American Indians, Abridged edition (Lincoln: University of Nebraska Press, 1986).

${ }^{28}$ Paige Raibmon, "Unmaking Native Space: A Genealogy of Indian Policy, Settler Practice, and the Microtechniques of Dispossession" in The Power of Promises: Rethinking Indian Treaties in the Pacific Northwest, Alexandra Harmon eds. (Seattle: University of Washington Press, 2008) 56 - 86; Bradley G. Shreve, "'From Time Immemorial': The Fish-in Movement and the Rise of Intertribal Activism," Pacific Historical Review 78, no. 3 (August 1, 2009): 403-34; Bradley G. Shreve, Red Power Rising: The National Indian Youth Council and the Origins of Native Activism (Norman: University of Oklahoma Press, 2012); Charles F. Wilkinson, Blood Struggle: The Rise of Modern Indian Nations, (New York: W. W. Norton, 2006); Sherry L. Smith, Hippies, Indians, and the Fight for Red Power (New York: Oxford University Press, 2012); Fisher, Shadow Tribe. 
By adding Charley's story to the larger fishing rights struggles of the Pacific Northwest, I contribute to an intergenerational story of active Indigenous leaders on the Columbia River. Michelle M. Jacobs, an enrolled member of the Yakama Nation and professor of American Indian Studies, incorporates Native-centered and intergenerational learning into what she calls a “decolonizing praxis." Her work recognizes the central role of history keepers in her community and utilizes a "grassroots Indigenous resistance as a mechanism to dismantle colonial logics." Her important work, Yakama Rising (2014), joins a growing body of scholarship on decolonization. Contemporary Indigenous intellectuals have challenged the settler-colonial education system by revitalizing traditional teachings and languages to foster healing and cultural revitalization. Jacobs and her cohort not only produce Native-centered histories but also provide ways for their work to benefit their communities.

Admittedly a product of the settler-colonial education system and a non-native cultural outsider, I do not purport to represent the Yakama Nation or the perspective of any Indigenous culture. Rather, I look to Jacobs and other scholars of decolonization as a beacon for non-native historians. Indeed, Jacobs asserts, “An Indigenous centered educational experience can benefit non-Indigenous students." Thus, this thesis presents Wilson Charley as the central figure in a history that complicates several historical subfields. I aim to challenge the ways in which non-natives see the Columbia River and understand Native resistance to state regulation of fisheries and dam building. By 
recognizing the leadership of one Indigenous leader, it is my hope that both Natives and non-natives will more fully understand how Wilson Charley was a proto-environmental leader ahead of his time. In many ways, he was not unique — many other Native leaders have made important contributions_ - but the records of their leadership remain guarded or lost. It is my hope that this thesis will inspire others to investigate other mid-twentieth century Indigenous leaders who defied stereotypes and worked in unexpected ways. ${ }^{29}$

\section{Sources and Methods}

Charley's story allows readers to empathize with an individual's struggle in a particular time and place. In his own words, the letters help readers understand complex and abstract topics such as identity, sovereignty, and Indigenous ownership from the perspective of an individual. From 1953 to 1965 Charley produced hundreds of unexpected letters on his typewriter articulating various strategies, policy dreams, and personal details. The typewriter helped him produce a rich historical record that affords readers a detailed, intimate picture of his leadership and legacy. In the tradition of surrendering to the archive, Charley's letters allow readers to alter how we visualize the past - a model articulated by the French historian Arlette Farge in The Allure of the Archive. In her study of eighteenth-century French court records, Farge brilliantly

\footnotetext{
${ }^{29}$ Michelle M. Jacob, Yakama Rising: Indigenous Cultural Revitalization, Activism, and Healing, (Tucson: University of Arizona Press, 2014), esp. 16 and 30; Myla Vicenti Carpio and P. Jane Hafen, Indigenous Albuquerque, (Lubbock, Tex: Texas Tech University Press, 2011); Linda Tuhiwai Smith, Decolonizing Methodologies: Research and Indigenous Peoples (Dunedin, New Zealand: Otago University Press, 1999); Joanne Barker, ed., Sovereignty Matters: Locations of Contestation and Possibility in Indigenous Struggles for Self-Determination (Lincoln: University of Nebraska Press, 2005).
} 
humanizes and gives voice to the subjects of her research, which society often marginalized. After numerous trips to the archive to read and collect copies of Charley's letters, I too found myself surrendering to the power of the letters and their ability to help me empathize with a man whom I never met, and from a time not of my own. ${ }^{30}$

The twelve-year collection of Charley's letters is part of the James James papers at the University of Oregon Archives and Special Collections. James "Jimmy" James, an artist and writer, moved to Portland, Oregon from Kansas sometime in the 1940s. Like most newcomers to the region, the scenic beauty of the Columbia River Gorge stunned James. Through his various field trips and readings, he gained a deep, albeit romantic, connection to the landscape and was increasingly curious about Native American culture on the river. Inspired to paint a series of "Indians at Celilo Falls and their way of life," James visited Celilo in 1951 to photograph Indians dipnetting from their scaffolds. Learning of the proposed dam at The Dalles, James wrote to the Bureau of Indian Affairs (BIA) in protest. "It is a shame that such beauty and attractions, not to speak of treaties, should go like this along with other broken promises.... Could not this dam be moved above or below [the falls]," wrote James. Unsatisfied with the BIA's procedural reply, James began a letter writing campaign to stop The Dalles Dam. He believed that Celilo could be "one of Oregon's leading attractions, but now it is to be exchanged for

\footnotetext{
30 Arlette Farge and Natalie Zemon Davis, The Allure of the Archives, trans. Thomas Scott-Railton, (New Haven: Yale University Press, 2015); Carolyn Steedman, Dust: The Archive and Cultural History (New Brunswick, N.J: Rutgers University Press, 2002).
} 
industry." One year later, after reading in the Oregonian of the Yakama Tribal Council's continued condemnation of the dam, James wrote to Yakama Tribal Chairman Alex Saluskin offering to support the tribe by writing to "influential groups" and political leaders. Saluskin thanked James and asked a delegation, including Wilson Charley, "to look further into the various organizations that you mentioned [are] interested in preventing the construction of the Dalles dam [sic] and saving the Columbia Gorge.” From this introduction, James and Charley developed a lasting partnership. ${ }^{31}$

Wilson Charley often mentioned how hard it was for Natives to maintain archives and access government records. Using his own money, Charley struggled to build an archive of fishing rights reports and records for his own tribe. However, he noted, "we need a secretary to do our filing but we cannot afford one." Requesting reports and records to be sent to the agency office, Charley expressed frustration of having to be there right when the mail arrived, "we have a file at the Agency but something like that [a report] they do not file. It goes in the waste basket," wrote Charley. James James became Charley's archivist and secretary. ${ }^{32}$

Charley understood that James was an important ally in this battle to stop The Dalles Dam. Bypassing the BIA, Charley had James keep the reports and files and had

\footnotetext{
31 James James to Bureau of Indian Affairs, Portland Area Office, Nov. 1, 1951, folder 55, box 1, JJP; James to "Chief of the Yakimas," March 27, 1952, folder 55, box 1, JJP; Alex Saluskin to James, 16 Jan. 1953, folder 46, box 1 , JJP.

32 Charley to James, Oct. 4, 1954, folder 42, box 1, JJP.
} 
copies sent to him and other officials when the time was right. When requesting meetings with influential senators and policy makers, Charley found his requests dismissed or lost in the mail. He feared that the BIA filtered his requests and thus, James wrote directly to powerbrokers. Having an intercultural ally helped spread the word. While, James claimed to have some Cherokee ancestry, for the most part, he only disclosed his Native heritage after building a rapport with various individuals. For the most part, James presented himself as a white middle-class retiree so that others would read his letters.

In their correspondence, James acted as Charley's proxy. Four hundred pages of Charley's letters are organized in two folders. All of James's outgoing correspondence is organized in separate folders by month and year. I digitized and used optical character recognition (OCR) for all letters from Wilson Charley, making them somewhat keyword searchable (except for his handwritten letters) to make larger comparisons more feasible. I also scanned all correspondence from James to Charley. Merging the letters together, it quickly became apparent that Charley was indeed directing James though much of the letter writing. Often Charley would articulate three or four ideas and ask James to prioritize one or two. Often the following day, James would write back with a draft letter to a senator or official. A few days later, Charley would give the green light, and the letter would usually be sent the same day with a carbon copy to Charley and one retained for James's records. While James had various side projects, the bulk of his letters were directives Charley issued. Further, I trace certain threads, like conversations with the 
Oregon Archaeological Society, Nature Magazine, or politicians to illustrate the depths of Charley's thinking and the successful networking opportunities that James connected to their cause. When Charley was traveling, he would sometimes send telegrams thereby expediting the letter writing process, during the fishing season he moved around receiving his letters at his drying shed at Lone Pine or his home on the reservation. All these detailed movements are in the letters.

I do edit Charley's quotations to a degree. If you have ever used a typewriter (few in my generation have), then you might understand that a single typo is nearly impossible to correct without retyping the entire page. Thus, the format of Charley's letters read like a stream of consciousness and his composition requires a careful eye for proper analysis. The letters are riddled with typos, grammatical errors, multiple sentence fragments, and run-on sentences - often because he knew James would do the final editing. When it is extremely clear, like correcting a "G" to a "C" or a simple misspelling, I have chosen to correct the quote for readability, but I limit these corrections as much as possible. Occasionally, when more extensive editing is needed, I use ellipsis points to end the quote and add in my own context before starting up the quote again. If I am concerned that an edit will change the context or interpretation of a sentence, I leave the quote as written and add [sic]. Otherwise, if adding a noun for context, I will add it in [brackets] or otherwise note the multiple interpretations. 
I arrange each chapter of this thesis thematically and because of Charley's multiple strategies, chapters often overlap chronologically. Chapter one begins with an overview of past Columbia River fishing rights cases and defines the term conservation. In this chapter, Wilson Charley worked with the Celilo Fish Committee (CFC), an intertribal governing body. As Oregon and Washington ramped up their assertions of state authority over Native fishers, Charley strategically pivoted away from the CFC and toward the power of the Yakama Nation's Treaty, which defined the right to fish at "usual and accustomed stations" off the reservation. Advocating for tribal regulations was a calculated move in Charley's attempt to keep Oregon and Washington out of regulating Native fishing.

Chapter two covers Charley's engagement with politicians and advocates at the center of the emerging environmental movement. Charley orchestrated two impressive political bluffs: First, alluding that Indians and Indian rights advocates had helped elect Richard Neuberger and later doing the same during Wayne Morse's reelection. Despite rampant Native disenfranchisement and living in a different state, the bluffs demonstrate Charley's ability to communicate with certain politicians and shows that some were willing to listen to Natives' concerns. Further, Charley was an unexpected protoenvironmentalist, reaching out to established conservation writers and environmental leaders who were hard at work protecting rivers from dams across the nation. These 
groups dismissed Charley, and their actions complicate the genesis narrative of American environmentalism and reinforce its elite or affluent suburban roots.

Chapter three provides a greater analysis of the importance of place and landscape in how Charley understood his history. Focusing on the salvage archaeological excavations behind the dam's pool, I trace how Charley and James originally sought the assistance of the volunteer Oregon Archaeological Society. Charley tried to meet and work with volunteer and academic archaeologists on multiple occasions, even revealing his own ancestors were buried in certain sites under excavation, but the archaeologists were more interested in the physical materials than the personal and spiritual connections these objects elicited among the descendent community. In the midst of this archaeological controversy, I also show how Charley ran into political trouble on the Tribal Council and how the BIA interfered with the election of 1955, where he lost his seat on the council.

Chapter four traces Charley's life after the completion of The Dalles Dam. Ever diligent that he and future generations would continue to fish, Charley proposed a multipronged economic development plan. However, the disbursement of the tribal settlement from The Dalles Dam made implementing his proposal impossible. I further show how he fought for personal damages to fishing stations and took his case to the U.S. Court of Claims. I trace his desire to participate in the state fish commission and give other Natives a seat at the table in planning the future of the river. This final chapter also shows 
the personal pain and emotional trauma The Dalles Dam inflicted on Charley's family. Finally, I conclude that his work indeed left a lasting legacy charting a path for the tribe and Columbia River Inter Tribal Fish Commission to be at the fore of environmental protection and social justice on the river today.

In general, Aboriginal Columbia River Fishermen have employed two different strategies to protect their treaty rights. One is to openly violate state and federal policies that contradict their rights in the hopes that the courts will resolve the issue. The other is a tactical strategy to influence politicians, administrators, and the public into supporting Native fishing rights, often through writing letters, using the press, and attending political meetings. Arrests and public protests have attracted media attention and scholarly analysis, while Native oral and written leadership has remained more opaque in scholarly investigations. Wilson Charley's letters, present the latter in detail, affording us a rich record of one man's fight to protect his rights against human-made environmental changes and aggressive bureaucrats.

Further, I establish culpability for the various groups and administrators that ignored Charley when he tried to collaborate with them. Often, historians avoid issuing judgments in such cases fearing anachronistic biases—and for a good reason. The rational "they didn't know any better in the past" needs to be more specific; of course, not everyone realized what was going on, but I want to be clear that certain powerful leaders did know; they choose to be silent or present other points of view-this is important. 
Through Charley's letters, it is clear that he equipped specific non-native leaders with alternatives and a clear oppositional rationale for The Dalles dam and state fisheries codes. Certain politicians knew dam projects would hurt Native fishers. Certain nonnatives knew that they could help resist flooding Celilo. Certain fisheries managers knew that Natives wanted a seat at the table.

The letters not only establish Charley as a clear, rational leader; they show, perhaps just as significantly, those specific individuals that ignored his concerns and suggestions. This was not tacit. It was explicit. They knew exactly how they could help and for various reasons did not. Their dismissal of his proposals not only set the foundation for a tenuous relationship between environmentalists and Native communities, but it continued to advance the ongoing colonial process of marginalizing Native communities and challenged the sovereignty of Indigenous nations.

Charley stood his ground willing to protect the Yakama's 1855 treaty against all odds. Given what was at stake with hostile state regulators and The Dalles Dam threatening Native fishing stations, Charley remained persistent and dedicated to this cause. Willing to negotiate and adapt ideas and policies on so many fronts, Charley was uncompromising regarding the language and power of the treaty. Often in his letters, he echoed an interpretation of the treaty's permanence: that his ancestors had secured the treaty protections for "as long as the mountain stands and the great Columbia River flows." It is a fitting interpretation because, although the rhetoric and environmental 
realities of the river change over time, Wilson Charley and many generations of Native leaders have and will continue to protect the treaty and the river's resources. 


\section{Chapter 1}

\section{"Salmon is one of our commandments": Wilson Charley Redefines Conservation}

"We love what mother nature puts here for us to consume, that is why we cherished conservation since the time of creation. For we know that if people take for themselves now, what will all the people one hundred years from now have?"

—Wilson Charley to James James April 14, 1954

"For a whiteman there must be regulation for that is the only way he understands or obeys. Without regulation the whiteman does not know what conservation means." — -Wilson Charley to James James, September 20, 1954

Wilson Charley imagined he might need to buy an aluminum drift boat and start fishing below Bonneville Dam with gillnets. Preparing for the First Salmon Feast at the Celilo Village longhouse in 1955, Charley recommended, "all the fishermen should go out and catch all the fish they can this year." With the completion of The Dalles Dam looming in the next few years, Charley's statement might appear to be the last hurrahfishing as much as he could before The Dalles Dam flooded the falls. In a way it was. Yet, on a deeper level, the statement begins to reveal his persistence in the face of one of the most significant historical traumas among the Indigenous communities of the Columbia Plateau. Charley hoped and prayed that Native Americans would continue to fish the river after the dam. Since the 1930s, before most people even had electricity, Charley had labored to adapt the mid-Columbia River fishery to serve his community better and allow fishermen to adjust to new markets and changing environments. 


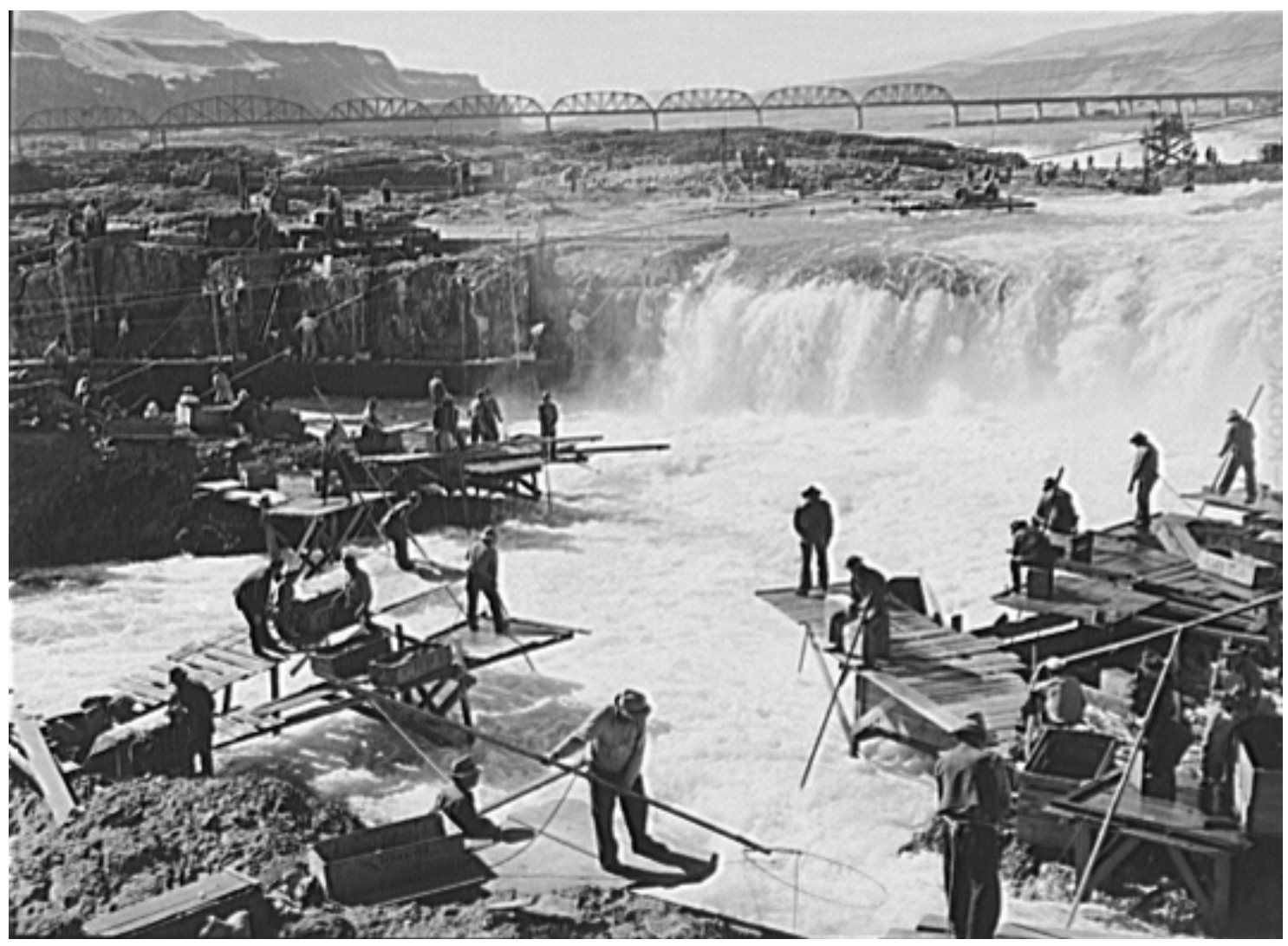

Figure 4 (top) Figure 5 (next page top) Figure 6 (next page lower): Russell Lee photographed Native Americans fishing at Celilo Falls in 1941. The scaffolds and locations were the property of select fishing families and the open and closed seasons regulated by strict cultural customs. Images from the Library of Congress Prints and Photographs Division. 


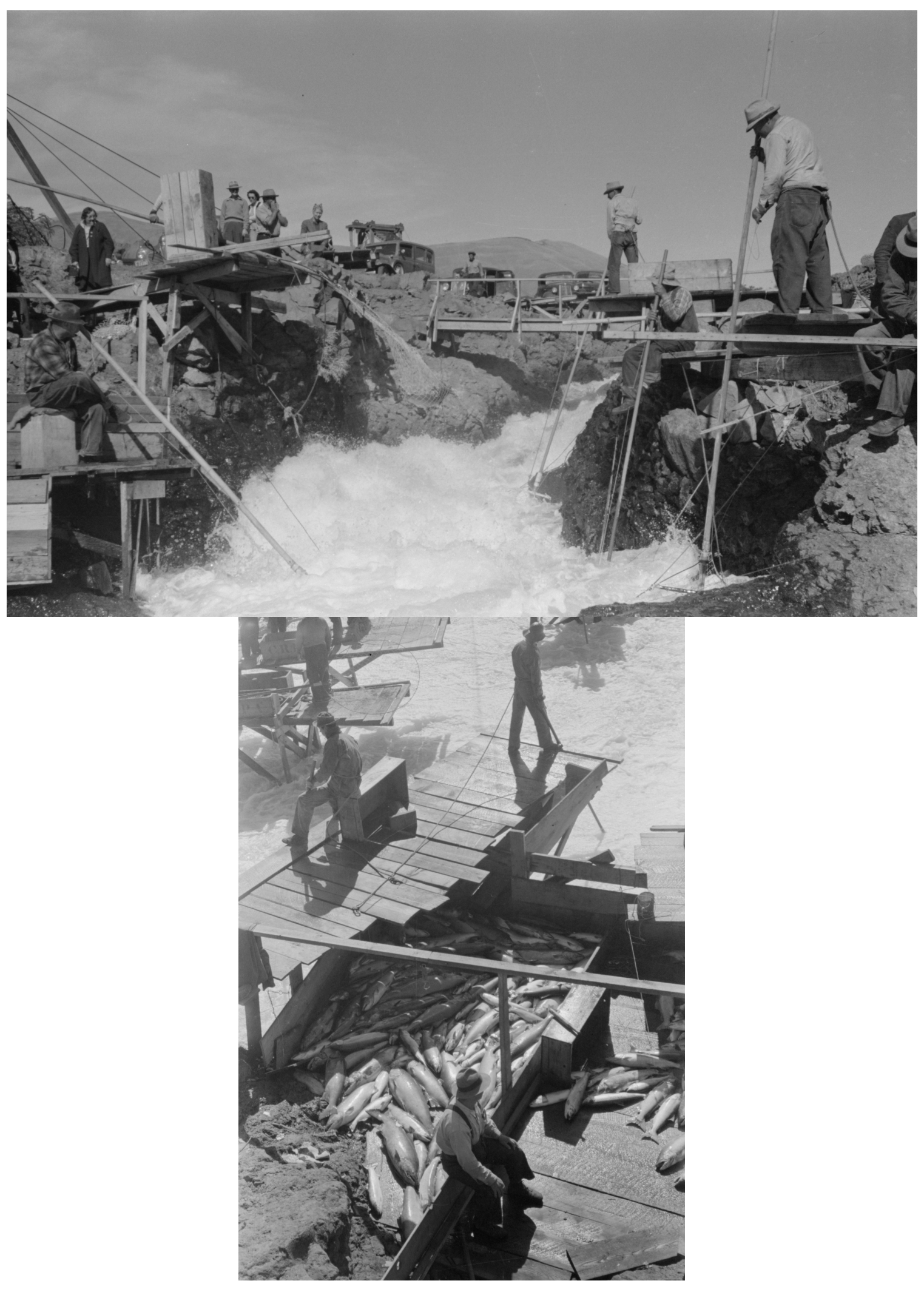


Charley saw no difference between subsistence and commercial fishing for Indianstreaty fishing was treaty fishing. However, since the turn of the twentieth century, many non-natives believed Indian fishermen were wasteful and wanton destroyers of salmon. State and federal fisheries managers employed terms like conservation and scientific management to curtail Indians' fishing rights. Few understood that Indigenous people had explicitly reserved the right to fish "at usual and accustomed stations" off the reservation and that these protections still were legally binding. Few bothered to ask how Indigenous people managed their personal fishing stations. Wilson Charley stood tall with answers to all these misunderstandings. He believed the 1855 treaty protections were applicable for all time — in the past, present, and future — and he fought for most of his life to make non-natives understand that Natives had regulatory systems over millennia. ${ }^{33}$

Wilson Charley's ancestors had managed the fishery before him. Wilson learned a great deal from his father Jobe Charley, himself a leader who fought for in-lieu sites after Bonneville Dam. Studying non-natives past efforts to curtail aboriginal rights, combined with his own family history, taught Wilson that Indians needed to organize, commercialize, and formalize their traditional regulatory structure in ways non-natives understood. Years before The Dalles Dam, the famous fish-ins of the Columbia and Puget Sound, or the landmark Boldt Decision, Charley had a solution: recognize Indian fishermen as equals in fisheries management. In appropriating the word "conservation"

33 Wilson Charley to James J. James, March 1, 1955, folder 42, box 1, JJP. 
into his Indigenous cultural practices, Wilson Charley constructed a rhetorical shield to protect his ancestral rights. Charley's strategy not only highlights his leadership but also challenges the hegemony of settler colonialism. Redefining conservation-a term of the colonizer - in his own terms protected aspects of his culture under threat. Grounded in innovation and tradition, Wilson Charley was a leader ahead of his time. ${ }^{34}$

\section{Background: Usual and Accustomed in the Courts}

Charley was not the first Columbia River Indian fisherman to fight for the recognition of his treaty-protected rights. Ever since the ink dried on the ratified 1855 Walla Walla Treaty, non-natives began to disregard the treaty's usual and accustomed protections. Throughout the nineteenth and twentieth centuries, non-natives considered Natives' fishing rights as a primitive commons. In viewing Native rights as static, nonnatives tried to regulate and nullify Indian fishing rights any time the river changed, or when fishers (especially Natives) developed new technologies. However, a series of court cases, the first three in the late nineteenth and early twentieth centuries, affirmed Natives' rights to usual and accustomed stations while also echoing non-natives misunderstanding of these explicit rights. The cases helped frame Charley's view that confronting the term conservation could uphold his rights in the mid-twentieth century.

\footnotetext{
34 Ranajit Guha, Dominance without Hegemony: History and Power in Colonial India (Cambridge: Harvard University Press, 1998); James C. Scott, Seeing like a State: How Certain Schemes to Improve the Human Condition Have Failed (New Haven: Yale University Press, 1999); James C. Scott, Domination and the Arts of Resistance: Hidden Transcripts, (New Haven: Yale University Press, 1992); Gerald Vizenor, Manifest Manners: Narratives on Postindian Survivance, (Lincoln, Neb.: University of Nebraska Press, 1999).
} 
The first case came in early 1884 . Frank Taylor, a non-native settler, had obtained waterfront property at prime sites along Tum Water (also known as the Long Narrows) fishery and fenced them off, preventing Indians from accessing their stations. A group of Yakama fishermen took Taylor to territorial Supreme Court in US v. Frank Taylor (1887). The decision affirmed that Taylor held title to his land, but the court clarified that article three of the treaty afforded Indians access to their usual and accustomed sites establishing "an easement upon [Taylor's land] at the time the government conveyed the title and that such title did not extinguish the easement." The court not only ruled that Indians could cross private property to access their usual and accustomed stations but more significantly that this right took precedent over non-natives established land claims. A victory in some senses, the lower court's decree defined the easement by using fixed trails and state defined seasons. Moreover, legal historian Barbara Leibhardt Wester notes that the court ignored the changing temporal and spatial dynamics of the riverscape, writing "into law a Euro-American version of Yakama fishing as... an overall scheme of privately held, state regulated rights." In other words, the court fixed Indian rights to borders that ignored the seasonal flux of the river's flow. In reality, the relationship between fishing stations and the riverbank was fluid, changing from year to year and decade to decade. ${ }^{35}$

35 The case was first ruled in Taylor's favor, the final decision was an appeal. United States v. Taylor, 13 P. 333 (Wash. Terr. 1887); Leibhardt Wester, Land Divided by Law; Andrew H. Fisher, "Reserved for Whom: 
Could new technologies nullify treaty rights? This question arose just a few years later at Celilo Falls. Non-native brothers Lineas and Audubon Winans constructed their fish wheels on both Washington and Oregon sides of the river and claimed that their technology was “one of the civilized man's methods," and annulled Native's treaty rights. Their racist logic assumed Indigenous peoples' fishing methods were frozen in stasis and lacked defined property. The reality was the exact opposite. At first, the courts agreed with the Winans and ruled that their fish wheels at Celilo were legal. However, on appeal, US v. Winans (1905) overruled the lower court's decision, thereby affirming that treaty Indians' reserved rights superseded non-natives property rights - even if new technologies, like fish wheels - changed the way individuals fished. Most significantly, the "court will construe a treaty with Indians as they understood it and as justice and reason demand," noted Justice Joseph McKenna. In other words, even as new technologies changed the river, the "right of taking fish at all usual and accustomed places... was not a grant of right to the Indians but a reservation by the Indians of rights already possessed." The implications of this decision were enormous for all future fishing rights cases because it opened the door for Native fisherman to adapt the ways in which they fished to the changing environmental realities of the river. It took years for non-

Defending and Defining Treaty Rights on the Columbia River, 1880-1920" in Alexandra Harmon, eds. Power of Promises: Rethinking Indian Treaties in the Pacific Northwest (Seattle: University of Washington Press, 2008), 186 - 214; Cohen et al., Treaties on Trial. 
natives to understand that Indians had and would continue to innovate new fishing technologies. Arguably, it is still an ongoing misunderstanding today. ${ }^{36}$

Non-native fishers exploited the complexity of tribal and cultural identities in their attacks on fishing. By the turn of the century, Francis A. and Theodore J. Seufert had amassed an empire of fish wheels and employed Indians to fish for their industrial cannery just east of The Dalles on the Oregon side of the river. One of their neighbors and fish suppliers was Sam Williams, the son of a Cowlitz mother and Yakama father. Williams had taken an allotment on the Yakama Reservation in 1897. Under the Indian Homestead Act, Williams, the minister at the neighboring Indian Shaker Church, filed a formal claim to the land and fishing sites at Wah-Sucks (known to non-natives as Lone Pine), where he built his fish wheel. Williams obtained Indigenous rights to the property from a man named Wasco Charley. In so doing, Williams gave acknowledgment to preexisting Native land claims, property rights, and cultural protocols held by Wasco Charley. ${ }^{37}$ However, the Seufert Bros. Company had already claimed the riverfront parcel at Lone Pine. When Williams stopped selling his catch to the cannery, the company sued. In the case U.S. ex. rel. Sam Williams v. Seufert Brothers (1919), the company claimed that Williams was not Yakama because he had renounced his tribal

\footnotetext{
36 United States v. Winans, 198 U.S. 371 (1905); Cohen et al., Treaties on Trial. Leibhardt Wester, Land Divided by Law, 123 -148; Fisher, "Reserved for Whom," 186 - 214.

37 The connection of Wasco Charley to Wilson Charley remains elusive in my research. However, Wilson did claim rights to fish at Lone Pine. It is unclear if Wilson's claim was based on the outcome of the case or his kinship to Wasco Charley.
} 
affiliation when he had filed a claim under the Indian Homestead Act. ${ }^{38}$ Further, they argued, the Yakama had no usual and accustomed claims on the Oregon side of the river. With numerous Natives testifying to the complexity of identity and kinship (including several with the last name Charley), the court ruled that Yakama enrollees had legitimate claims to sites on the Oregon side of the river. However, the outcome was less favorable for Williams.

As the court pointed out, Williams, under the conditions of owning a fee-simple Indian homestead, had "voluntarily separated himself from his tribe... and adopted the habits of civilized life." Thus, the court asserted, Williams had revoked his treaty rights. Building his fish wheel on fee-simple land, Williams was subject to the rules and regulations of the state of Oregon like any other citizen. However, Oregon district court Judge Charles E. Wolverton clarified that Indians were not to avoid adopting new technologies. "I see no reason why Indians may not be permitted to advance in the arts and sciences as well as any other people, and, if they can catch their supply of food fish by a more scientific and expeditious method, there exists no good reason why they may not be permitted to do so," opined Wolverton. "Even more," he continued, "they ought to be encouraged to adopt the more modern and advanced ways of prosecuting their

${ }^{38}$ U.S. ex. rel. Sam Williams v. Seufert Brothers (1919); Fisher, "Reserved for Whom," $186-214$. 
enterprises." Some forty years later, the decision still had tremendous resonance with Wilson Charley in his fight against The Dalles Dam. ${ }^{39}$

\section{Defining Conservation and State Intervention}

While the first three cases all affirmed Native treaty rights, the cases also continued to introduce nuanced loopholes which non-natives exploited. Indeed, Wilson Charley and other Native families still faced a changing landscape. Enterprises like irrigation diversions, hydraulic mining, and flash dam logging were rapidly expanding across the Columbia Basin at the turn of the century. These industries took an enormous toll on fisheries by reducing spawning grounds before hydroelectric dams were ever a serious factor. Moreover, with new commercial fish canneries climaxing during the First World War, state authorities in Oregon and Washington began to implement restrictive regulations on fisheries - with a particular focus toward Native fishermen. It was in this historical context that the term conservation came into wide use among state fisheries regulators and hatchery officials. ${ }^{40}$

Conservation is a problematic term, especially among historians and anthropologists. Eric A. Smith and Mark Wishnie define conservation as "practices or actions that are intentionally designed to prevent or mitigate resource overharvesting

${ }^{39}$ U.S. ex. rel. Sam Williams v. Seufert Brothers (1919); Francis Seufert, Wheels of Fortune (Portland: Oregon Historical Society Press, 1981); Cohen et al., Treaties on Trial; Fisher, "Reserved for Whom," 186 - 214; Joseph C Dupris, Kathleen S Hill, and William H Rodgers, The Si 'lailo Way: Indians, Salmon, and Law on the Columbia River (Durham, N.C.: Carolina Academic Press, 2006), 105 - 117.

40 Taylor, Making Salmon; White, The Organic Machine; William G. Robbins, Landscapes of Promise. 
and/or environmental damage." Their definition of conservation as an intentional action suggests that ecological change and economic scarcity drive implementation. The intentionality of conservation, then, nicely fits the historic context of the mid-Columbia River in the twentieth century - as the landscape was indeed changing and intentional actions were necessary to prevent overharvest. Ethnographer Eugene Hunn suggests the relative stability of aboriginal fisheries to be the result of "ephinomial conservation," or the indirect consequences of a highly mobile society. In other words, precontact populations did not necessarily manage the fishery intentionally for the conservation of resources, but rather, had such a wide pool they never depleted a single resource. However, such views, while possible, limit the agency of individuals and the complexity of cultural practices. Moreover, any singular rationale for precontact conservation is overly simplistic. ${ }^{41}$

In their archaeological study of salmon population resiliency in the Pacific Northwest, archaeologists Virginia L. Butler and Sarah K. Campbell, conclude that social institutions and cultural beliefs were likely one of many key factors in regulating stable salmon populations for over 7,500 years. In part, their conclusions rest on archaeological and ethnographic evidence of the mid-Columbia where they write; the "Plateau is rich

\footnotetext{
41 Eric Alden Smith and Mark Wishnie, "Conservation and Subsistence in Small-Scale Societies," Annual Review of Anthropology 29, no. 1 (2000): 493-524; Eugene Hunn, "The Utilitarian Factor in Folk Biological Classification," American Anthropologist 84, no. 4 (December 1, 1982): 830-47; Joseph E. Taylor III, "Burning the Candle at Both Ends: Historicizing Overfishing in Oregon's Nineteenth-Century Salmon Fisheries," Environmental History 4, no. 1 (January 1, 1999): 54-79.
} 
with examples of harvest regulations, beliefs, rituals, and practices argued to contribute to resource conservation in other small-scale societies." Yet, when historicized, the ideas of overharvesting and conservation fail to fully describe the precontact past because intentionality is rarely so explicit in the archaeological and ethnographic record. ${ }^{42}$

Conservation is a western concept rooted in the Progressive Era and closely tied to elite technological and scientific management. It is anachronistic to claim Indigenous societies ten thousand years ago practiced a type of conservation analogous to the Progressive Era. However, historian Joseph Taylor notes, “Indians' ability to sustain their intensive fisheries suggests that a new image is required: Indians were seasoned, rational fishers." Moreover, Taylor, Arthur McEvoy, and others have shown that nineteenth and twentieth-century conservation managers were not the objective scientists they purported to be. Instead, federal and state fish and game officials molded conservation science and regulation to fit their cultural views and priorities - like fusing hatcheries to favor recreational anglers over commercial fishers. The ways in which officials managed, regulated, produced fish in hatcheries, and who they allowed to harvest this resource, all fell under the power of state and federal authority. Conservation became a new weapon

\footnotetext{
42 Sarah Campbell and Virginia Butler, "Archaeological Evidence for Resilience of Pacific Northwest Salmon Populations and the Socioecological System Over the Last 7,500 Years," Ecology and Society 15, no. 1 (January 1, 2010); Virginia L. Butler and Sarah K. Campbell, "Resource Intensification and Resource Depression in the Pacific Northwest of North America: A Zooarchaeological Review," Journal of World Prehistory 18, no. 4 (December 1, 2004): 327-405; Butler and O’Connor, "9000 Years of Salmon Fishing."
} 
for colonial governments to assert their own "fish culture," not fisheries science, in their efforts to curtail aboriginal fishing rights. ${ }^{43}$

\section{Dams and Native Fishing Rights}

Fish culture had many components, but Yakama fishermen realized its relationship to dam building long before The Dalles Dam proposal. For Washington state officials the consequences of flooding aboriginal fishing grounds introduced an idea that dams annulled Native fishing rights. The Bureau of Reclamation's (1914) Prosser Dam on the Yakima River dramatically altered the aboriginal fishery at Tóp-tut (also known as Prosser Falls). By the twentieth century, the falls had become an important subsistence fishery because of their proximity to the Yakama Reservation, and by the simple fact that there were fewer and fewer places to fish. After the dam's completion, state authorities arrested Yakama tribal member Alec Towessnute for fishing with a gaff hook within one mile of the dam; a violation of the 1915 Washington state fisheries code. The court ruled that the state had the right to regulate Indians for the conservation of the fisheryimplying those Native fishers, and not the proliferation of dams, threatened fish populations. Immediately following the decision, Yakama tribal members went fishing at

\footnotetext{
43 Samuel P. Hays, Conservation And The Gospel Of Efficiency: The Progressive Conservation Movement, 1890-1920, (Pittsburgh: University of Pittsburgh Press, 1999); Taylor, Making Salmon; Arthur F. McEvoy, The Fisherman's Problem: Ecology and Law in the California Fisheries, 1850-1980 (Cambridge: Cambridge University Press, 1990); Harris, Fish, Law, and Colonialism; Jacoby, Crimes against Nature; Warren, The Hunter's Game; Cain Allen, "Replacing Salmon: Columbia River Indian Fishing Rights and the Geography of Fisheries Mitigation," Oregon Historical Quarterly 104, no. 2 (July 1, 2003): 196-227. The tribal members were: George Meninick, Jim Wallahee, and Al and A.J. Barnhardt.
} 
Tóp-tut in strategic violation of the Towessnute decision. Seeking a reversal in Washington State Supreme Court, the fishermen's impassioned testimony was not enough for the justices to reverse the state's police power. Jim Wallahee (Yakama) pleaded, "I fish at this place my father saved for me and which the great spirit made for the Indians. Is it right for the white man to build a dam at the falls and then say that [Indians] destroy the bounty of the creator?” The court remained unconvinced. They upheld the decision in State v. Towessnute (1915) and convicted the four fishermen for violation of the state's conservation laws. ${ }^{44}$

There was still hope for Indian fishing at Tóp-tut. In 1921, when Meninick and company were in court, other tribal members donned regalia and pleaded with the state legislature to intervene-including Wilson's father, Jobe Charley. ${ }^{45}$ Sympathetic, the Washington State legislature introduced Senate Bill 52, which established a policy for Yakama Indians to ignore state prohibition of fishing at Prosser Falls and to "take salmon or any other food fish, by any reasonable means, at any time." Governor Louis F. Hart quickly vetoed the bill, noting, "the fact that Indians do not like to acknowledge the supremacy of the law or to acknowledge the dominant power of the State is not a reason, in my opinion, for permitting them to indiscriminately fish at the Prosser Falls Dam and

\footnotetext{
${ }^{44}$ State v. Towessnute 89 Wash. 478, 154 Pac. 805 (1916); Fronda Woods, "Who's in Charge of Fishing?," Oregon Historical Quarterly 106, no. 3 (October 1, 2005): 412-41; Dupris, Hill, and Rodgers, The Si'lailo Way, 223-37.

45 "Yakima Indians ask Right to Fish" Spokane Chronicle, May 17, 1920.
} 
to exercise privileges denied the white people.” The legislature overrode the veto and passed the bill anyway, effectively bypassing the courts and the state executive. Yakama could now fish unregulated by state conservation laws at Tóp-tut. Yet, the precedent established that the state could use conservation regulations to curtail Indians rights virtually anywhere else. According to State Fish Commissioner L.H. Darwin, Senate Bill 52 would "really amount to nothing." Darwin looked to future dam "developments of the next ten years [that] will demonstrate conclusively that the Yakima River will largely have to be eliminated from consideration as a spawning tributary." Instead, Darwin wanted to concentrate state conservation enforcement and hatchery programs in other areas. "In my judgment," he noted, "the best opportunity lies further down the Columbia." However, Wilson Charley had learned a lesson from his father: not only could Natives challenge state power in court and in the state house, but there were sometimes sympathetic non-natives who were willing to help. ${ }^{46}$

\section{The Celilo Fish Committee}

Despite the success at Tóp-tut, by the 1930s there were simply fewer places for Indians to fish. Construction of Bonneville and Grand Coulee Dams dramatically altered most of the aboriginal fishing grounds in the Columbia Basin. With the loss of sites across the Northwest, Celilo Falls increasingly became a bottleneck site for Indians, some

${ }^{46}$ House Journal of the State of Washington (Olympia: State Printer, 1920), 576-77; L.H. Darwin, Thirtieth and Thirty-First Annual Reports of the State Fish Commissioner (State Fish Commissioner of State of Washington, 1921), 27-29; Dupris, Hill, and Rodgers, The Si 'lailo Way, 223-37; Woods, "Who's in Charge of Fishing?," 418. 
traveling as far away as Montana. ${ }^{47}$ The increasing numbers of Indians fishing at these sites could cause conflict, especially given that these sites were the hereditary property of select families. Proper protocol dictated that one must have permission to fish at each site as well as observe the direction of Salmon Chief on the appropriate times to fish. However, as early as 1922, not everyone followed the protocol. Thus, mitigating conflicts between "home folk" and increasing numbers of "comers," terms used by Celilo Chief Tommy Thompson to describe visiting Indian fishermen, became a challenge. ${ }^{48}$

Founded in 1935 under the direction of the Indian Reorganization Act, the Confederated Tribes of Warm Springs, the Confederated Tribes and Bands of the Yakama Nation, the Confederated Tribes of Umatilla Indian Reservation and unenrolled river chiefs, organized the Celilo Fish Committee (CFC). The CFC established its set of bylaws to govern fishing disputes along the Columbia between the John Day River and Cascade Locks. Further, the committee resolved conflicts between fishermen and set regulations. One of its earliest regulations set open and closed seasons as well as prohibiting fishing at night. Yet, the committee had no legal enforcement capacity. Instead, it relied on the collective respect of its participants. When legal questions came

\footnotetext{
47 Roberta Ulrich, Empty Nets.

48 Andrew H. Fisher, "Tangled Nets: Treaty Rights and Tribal Identities at Celilo Falls," Oregon Historical Quarterly 105, no. 2 (July 1, 2004): 178-211; Fisher, Shadow Tribe, 155 - 191.
} 
about, judges on the tribal courts took up the matters, with each reservation judge trading off. 49

Wilson Charley first served as the CFC's secretary and later as chair. ${ }^{50}$ As the traditional regulatory authority at the falls, Celilo Chief Tommy K. Thompson did not approve of the CFC because he felt the BIA had given too much power to the tribes, especially the Yakama. ${ }^{51}$ The CFC's twelve-man committee recognized the authority of the BIA to bestow power to the colonially constructed tribal governments, and many Columbia River Indians, like Thompson, feared it would oversimplify and challenge the traditional regulatory framework. While members of the committee internally agreed to honor Thompson's authority at the falls, he knew the salmon chiefs had little authority in the eyes of the federal government. ${ }^{52}$

While Charley's kinship gave him access to Lone Pine and Celilo, tribal authority was recognized, even emboldened, by federal Indian policy under John Collier. A 1939 BIA circular authored by Collier applauded the Yakamas for obtaining riverfront allotments from Roosevelt to White River, which would allow for greater access to tribally controlled fishing stations. In securing these sites, the circular declared, "This

\footnotetext{
${ }^{49}$ Laura Berg, “As Long As the Rivers-Run: A History of U.S. v. Oregon and Four Tribes' Fight for Columbia River Salmon" Unpublished manuscript, (Portland: Columbia River Inter-Tribal Fish Commission, 1992) 8.

50 Wilson Charley to James James, Aug. 22, 1964; folder 43, box 1, JJP.

51 Berg, "As Long As the Rivers-Run."

52 Ibid, 170-175.
} 
area is of particular interest because at Celilo the Indians are making strides to regulate their own industry and to work out with Indian Service officials [my emphasis] the many settlements of problems which arise in the fishing and marketing of salmon." The circular also praised the tribes for their self-regulation, which allowed some 3,000 Indians to obtain salmon for winter subsistence and an additional thirty heads of families earned about $\$ 40,000$ annually from fishing commercially. Supporting Collier's idea for a "modification of traditional customs" for economic improvement among reservation populations, Charley wrote, "if you can modify family groups and customs, we can modify the whole of Indian lifeway, and do more economically and do more rapidly." Although focused on the tribe and not individual families, Charley took Collier's ideas of modification of custom and tribal regulation seriously. However, Charley dismissed Thompson's fear that the BIA was too heavily involved. Collier's well-intentioned plan emphasized BIA involvement with tribal regulation, effectively stripping power from river families. 53

Indeed, Thompson's concern that the CFC was beginning to give preference to treaty Indians over river families was legitimate. One of the earliest regulations set forth by the CFC required Indians to carry identification cards or tribal fishing licenses, overruling unenrolled river Indians' traditional ownership rights. Additionally, the tribal

\footnotetext{
53 John Collier, "The Silver Horde: The Salmon Industry and Indians in the Northwest," in Indians at Work: A News Sheet for Indians and the Indian Service, vol. 7, no.7 (March) (Washington, D.C.: United States Office of Indian Affairs, 1939) 4 - 6.
} 
delegates, especially Jobe and Wilson Charley, advocated making fishing stations tribally designated, giving equal access to all tribal members. When traditional property owners and river chiefs resisted allowing "comers" to fish at their stations, U.S. District Attorney Carl C. Donaugh wanted to intervene. "You have no right to prevent other Indian people from fishing from the same rocks you are fishing from.... hoping you will comply.... If you do not do this immediately, I will have to ask for an order bringing you into court," threatened Donaugh. ${ }^{54}$

Wilson Charley had his own idea: modify custom and bring industrial efficiency to the Indian fishery at Celilo. In August of 1939, Charley, then chair of the CFC and the Yakama Tribal Game, Fish, and Wildlife Committee, approached the BIA with a proposal to construct a large refrigeration warehouse at Celilo. The prospective structure would permit local and traveling Indians to both fish and store their catch until the commercial season opened, thereby allowing Indians to sell when market prices were most favorable. This plan would have cemented the mid-river fishery in real economic figures, providing Indian fishermen with a stable and self-supporting income. As an intertribally managed enterprise, Charley's refrigeration concept simplified the Indian commercial catch, bringing uniform profits and protections to all fishers involved. It also lessened competition between individual fishermen and could have given the economic

${ }^{54}$ Carl C. Donaugh to Isaac Albert and Other Members of the Fish Company, Sept. 13, 1939, Field Agent-The Dalles, OR, General Subject Correspondence 1939 - 1953, Portland Area Office, Records of the Bureau of Indian Affairs, RG 75, National Archives and Records Administration-Pacific Alaska Region, Seattle, WA (hereinafter Portland Area Office). 
advantage to Native sellers. The plan could sever the reliance on white fish buyers like the Seuferts in setting fish prices. At the same time, these new storage and processing technologies could maximize harvests and profits while also allowing fish to escape at the beginning and end of the season. ${ }^{55}$

Charley's plan embodied intentional actions to mitigate waste and maximize efficiency. The central, but simplified, governing body of the CFC could regulate the plan. He had demonstrated clear forms of conservation that subtly protected millennial traditions in the context of his time. However, the refrigeration warehouse proposal failed because of three interconnected reasons. First was the continuing quagmire of state and federal authority to regulate the dwindling fish stocks. The second was the growing power of non-Indian sportsmen's associations. The third was the development of hydroelectric dams on the river. Fearing the imposition of Oregon and Washington state fish and game regulation, the Portland area BIA office urged Wilson Charley to abandon his plan. Instead, he took it head on using the authority of Yakama tribal government and the 1855 treaty to regulate Indian fishing.

\section{Family and Tribal Rights Overlap}

Throughout the 1930s and 1940s, the authority of tribal governments and traditional river chiefs became a common point of contestation at $\mathrm{CFC}$ meetings. One meeting, in particular, illustrated the Charley family's position. 'I feel I should own this

\footnotetext{
55 For a much fuller discussion of his plan see, Dupris et. al., The Si 'lailo Way, ch. 17.
} 
land. If this land is owned by whites the white man will drive me away.... We should purchase the land and own the title," noted Jobe Charley as he suggested the treaty tribes buy Celilo Falls and incorporate it into reservation holdings. Tommy Thompson corrected Jobe, "I am not asking the reservations put up tribal funds to purchase land for me. I am asking for a general appropriation from Congress so I can not be bothered by reservation tribal funds." Chief Thompson, the Salmon Chief at the falls, further contrasted his position to reservation leaders like Jobe. "I am poor and do not have any home on a reservation and no allotment, and I have to live from fish I catch at Celilo." As tensions rose, Wilson took to the floor. “All we ask is peace...we don't want the title from you. You don't understand," Wilson said to Thompson. "When the land is purchased the three reservations shall never own the title. We have seven acres now, but the custom [of] fishing does not connect with [all our] land. If we have the lands joining fishing places we can control the rights," declared Wilson. Elder and younger Charley wanted the Celilo Fish Committee and the BIA to manage a complex network of tribal lands and Indian personal property. The Charley family feared that without treaty protections the states would continue to curtail unenrolled river Indian's rights. Thompson feared that the BIA could too easily assert control over the tribes and that moving further away from the traditional regulatory structure, outside forces would subtly curtail treaty protections. ${ }^{56}$

56 Minutes of Regular Meeting of the Celilo Fish Committee, Sept. 3, 1941, folder 155, box 12, Field 
Thompson's fears were again correct, but federal development and changing policy situated the physical and political landscape of the river under far greater threat. Historian Andrew Fisher notes, "the official designation of 'treaty sites' also signaled the growing acceptance of tribal sovereignty and tribal property at the fishery." ${ }^{\circ 7}$ Despite the simplification of the CFC, the power of a consortium of tribal authority became increasingly important in protecting Natives' access to fish. At the same time, the CFC continued to resolve disputes among Indians, and for the most part, helped protect fishing families from aggressive state and federal authorities.

Wilson Charley stood in the middle of this tension between traditional kinship and tribal ownership. In June of 1942, the CFC mediated a dispute between Amosshiet Charley and Pete Soctillo over the ownership and access to fishing stations at Celilo. Amosshiet had married Jobe Charley after the passing of Wilson's mother, making her his stepmother. It is unclear if there was a direct correlation, but Wilson did not attend this particular meeting, perhaps to recuse himself. Amosshiet stated, "I am born and raised here at Celilo." She recalled that her family had long owned a rocky ledge but had loaned the site to a widow and her children for several generations. Years later, with the children of the widow now dead, Amosshiet wanted the CFC to recognize her rightful possession over Pete Soctillo. "I can have someone fish for me, but everybody can fish

Agent-The Dalles, OR, General Subject Correspondence 1939 - 1953, Portland Area Office.

${ }^{57}$ Ibid, 180. 
there," she stated making it clear that she wanted her rights recognized. Tommy Thompson testified in support of Amosshiet's request. "Mrs. Jobe Charley made a statement, it is all true. Myself, I helped build the scaffold," noted Thompson as he connected his authority as an architect and regulator of new and old fishing stations alike. Soctillo, likely persuaded by Thompson's authority, recanted his claim. "I don't want to dispute them, [she is an] old woman...they can send their boys over to fish for them," he noted affirming both her rights and those of her kin. Deciding in her favor, the CFC placed Tommy Deschutes in charge of overseeing that Amosshiet's priority rights. The dispute illustrates that while overlapping identities led to contestation, the CFC still could at times mediate conflict and keep order. Indeed, identity complicated fishing rights, but the CFC was far better at mediation than any state or federal authority because although not legally enforceable, the committee could at least recognize the rights of families in subtle ways. ${ }^{58}$

\section{Conservation as a Weapon of the State}

While the CFC understood the nuances, federal and state authorities still could not make sense of which Indians had treaty fishing rights and how far they extended. Regarding fishing sites on the Klickitat River, BIA field agent Clarence G. Davis wrote, "I had to advise Mr. Barnhart [Umatilla] and Mr. Thompson [unenrolled] frankly that I

58 Andrew Fisher notes Thompson's earlier animosity toward Henry Charley and Pete Soctillo for not asking permission to open the soda shack on Chief Island. Minutes of Regular Meeting of the Celilo Fish Committee, June, 3, 1942, folder 155, box 12, Field Agent-The Dalles, OR, General Subject Correspondence 1939 - 1953, Portland Area Office; Fisher, Shadow Tribe, 155. 
could not honestly advise them as to their particular rights on the Klickitat River.” Pleading for clear directives from the BIA, Davis wanted "definite information as to where they can and cannot fish without subjecting themselves to prosecution by the state." Additionally, Davis took pages of testimony from unenrolled Indians who fished the Klickitat River on Yakama territory and were requesting Yakama Indian ID cards so that they could fish without molestation by state authorities. ${ }^{59}$

New federal and state fish managers looked to use conservation as the weapon to curtail Indian rights. In 1938, Congress passed the Mitchell Act, which by 1940 had given authority to the U.S. Fish and Wildlife Service (USFWS) to expand salmon conservation programs. In 1942, empowered by an intoxicating optimism in fish hatchery technology, and new powers under the Mitchell Act, the BIA’s Clifford Presnall, specifically targeted Indian fishing at Celilo for federal conservation regulations. Citing the need for wartime management, Presnall aimed to impose state conservation regulations on the tribes. ${ }^{60}$ Presnall, in his earlier work, scoffed at claims that Columbia River Indians ever practiced anything close to conservation, even accusing Indians of being wasteful. Moving to advance his career from the BIA into the USFWS, Presnall's call for state regulation of Indian fishing ignored the prior work of the CFC and the

59 C.G. Davis to L.W. Shotwell, June 5, 1943, folder 155 k, Box 1945, Relations and Cases, Field AgentThe Dalles, OR, General Subject Correspondence 1939 - 1953, Portland Area Office.

60 Clifford Presnall, "The Conservation of Indian Game and Fish," in Indians at Work: A News Sheet for Indians and the Indian Service, vol. 9, March 7 (Washington, D.C.: United States Office of Indian Affairs, 1942), 5-9. 
objections of BIA field agent C. G. Davis. Unwilling to speak publicly against Presnall, Davis noted, "Mr. Presnall has become 'sold' on the idea that Indians are great wasters of game and fish, and that it is necessary to place all kinds of restrictions on them.... The white man in this country has been the biggest waster in history." In targeting Indians over the non-native sport and industrial fishers, and ignoring the CFC's own regulations, Presnall was indeed a fish culturist rather than a conservation scientist. 61

At the same time, Presnall's rhetoric translated into law. The year he called for greater federal regulation of Indian fishing, a U.S. Supreme Court case kept the waters murky for state regulation. Sampson Tulle v. Washington (1942), a test case to determine the authority of states to regulate off-reservation fishing at usual and accustomed sites, overruled Washington State's law imposing fish licensing fees on Indians. However, the case was not the legal victory Native fishermen wanted. Justice Hugo Black noted in his decision, "the treaty leaves the state with the power to impose on Indians, equally with others, such restrictions of a purely regulatory nature concerning the time and manner of fishing outside the reservation as are necessary for the conservation of fish." In other words, the court left state regulation at usual and accustomed sites wide open as long as it did not impose licensing fees. Moreover, the ongoing rhetoric demonstrated that state and

61 C.G. Davis to M.A. Johnson, May 27, 1942, folder 155 k, Box 1945, Relations and Cases, Field Agent-The Dalles, OR, General Subject Correspondence 1939 - 1953, Portland Area Office; Dupris, et. al., The Si'lailo Way, 242-44. 
officials had their eyes locked on controlling Indian rights and the term conservation was the vehicle. ${ }^{62}$

The BIA had considered an alternative solution. Edward Swindell Jr., a BIA attorney, conducted an extensive study of fishing sites remaining after the construction of Bonneville Dam. His detailed report concurred that Tulle v. Washington clarified that the states had the power to regulate Indians under the guise of conservation. However, he also noted that Oregon had passed specific legislation that allowed Indians to fish for subsistence - a model he hoped to encourage. "Indian Service field administrative officials can be of considerable assistance in the development of a better understanding between the state authorities and the Indians," wrote Swindell as he outlined the need for BIA officials to advocate for Indians while also upholding state laws. Swindell's thinking focused on the power of states, not the tribes or the CFC, to regulate fishing. Still, his detailed report produced some innovative methods and suggested ways to address the pitfalls of state power and conservation regulations. In the end, it would require the BIA to advocate for the tribes and history had already shown the gulf between idea and reality in the BIA. Regardless, World War II delayed the report's release for a decade, making any impact it might have moot. All the while, the states and federal officials continued

62 “Tulee v. Washington 315 U.S. 681 (1942)," Justia Law, accessed January 5, 2017, https://supreme.justia.com/cases/federal/us/315/681/case.html. 
their assault on treaty fishing rights. 63

\section{The Coming of The Dalles Dam}

The earliest proposal for the Tenino Dam at The Dalles in 1945 alarmed Wilson Charley and other Native fishermen. For Charley the confusing layers of authority (individuals, tribes, the CFC, states, or BIA) made it unclear who could lead the fight against the dam. In April of 1945, Jobe and Wilson returned from a meeting in Seattle where they had tried to negotiate for damages to sites flooded by Bonneville Dam. Relaying their strategy before the $\mathrm{CFC}$, it became clear to the committee that each tribe needed to organize formal delegations to protest the new dam before Congress. By early September, the CFC called in fishermen from the fall run for an emergency meeting and the Yakama and Umatilla tribes began planning their formal protests of The Dalles Dam. With the conclusion of the fall fishing season in 1945, the CFC passed resolutions explicitly for conservation purposes: forbidding night fishing and selling fish on the black market. 64

The state continued to use conservation against Native fishermen. A Washington state hatchery on the Klickitat River became a major point of contention as state

\footnotetext{
63 Swindell's detailed report was not released until 1952, Edward G. Swindell, Report on Source, Nature and Extent of the Fishing, Hunting and Miscellaneous Related Rights of Certain Indian Tribes in Washington and Oregon Together with Affidavits Showing Locations of A Number of Usual and Accustomed Fishing Grounds and Stations. (Los Angeles, Calif.: United States Department of the Interior, Office of Indian Affairs, 1942), 71-89.

64 Minutes of Regular Meeting of the Celilo Fish Committee, April 4, 1945, folder 155, box 12, Field Agent-The Dalles, OR, General Subject Correspondence 1939 - 1953, Portland Area Office; L.W. Shotwell to Henry Roe Cloud, Sept. 14, 1945, folder 155u, box 1946, ibid.
} 
authorities arrested unenrolled Klickitats. Continuing to fish in violation of state policies, the Klickitat fishers passed a resolution in 1947 asking for BIA intervention and payment for their lost gear. "The state wants to control everything," the resolution put simply. Yet, Charley saw the loophole: the BIA would only deal with the tribes and not the unenrolled Klickitats. The Klickitats continued to challenge the authority of the state and in later years, the CFC, and especially the Yakama Nation, tried to police the Klickitat River fishery. Charley came down hard on these fishermen for not falling in line with the tribes and the CFC: "You should remember that your violations are not entirely against the state of Washington but that you are acting against the Yakama Tribe," noted Charley. It, and many other cases stand as reminders of the complexity of identity and regulatory authority. While Wilson did not want to impose on the Klickitat fishermen, he later reflected that he felt it necessary for the tribal governments to establish "rules and regulations...for Indian fishermen" because the treaties gave such explicit protections to the tribes. Still, he acknowledged that his work angered many of the older generation of fishermen. ${ }^{65}$

\section{Dams and Conservation}

Wilson Charley sensed what fisheries managers and dam planners were up to. Charley needed to sidestep the BIA and establish conservation ordinances within the CFC

\footnotetext{
65 Resolution drafted by Cecil Wesley and Caples Dave, Feb. 16, 1947, folder 155u, box 1946, ibid; Charley to James, Aug. 8, 1964, JJP; Charley is quoted in Fisher, Shadow Tribe, 210.
} 
or Yakama Nation to get away from state regulation if they were to have any say in the future of the fishery. He was fighting against a plan not yet fully formed. Ever since the Mitchell Act, Oregon and Washington were working on a long-range plan to replace wild salmon runs with hatcheries concentrated below Bonneville Dam, and an all-out closure of the commercial catch above Bonneville. In other words, additional dams and hatchery programs had mixed to form an optimistic Kool-Aid that state fisheries managers and dam planners were drinking. Planners were not thinking in terms of dams versus fish like many think of today. Instead, technological optimism and insular thinking promoted an optimistic future where dams and fish (via hatcheries) could coexist - even thrive. Under the past fishing rights case law, state authorities looked to hatcheries and dams with the fortunate ability to curtail Native fishing rights. ${ }^{66}$

Of course, there were dissenters. Click Relander, a non-native journalist, preservationist, and ally to the Yakama, had been forwarding Wilson Charley the fish counts from the hatchery and Grand Coulee Dam. The fish counts were abysmal and the irrigation diversions did not return to the river in numbers reclamation officials had hoped. For Charley, the abandonment of the Grand Coulee fish hatchery program, the false promises, and the engineering miscalculations were enough to demonstrate that any Army Corps or Bureau of Reclamation official was too steeped in optimism to be critical

\footnotetext{
66 Paul W. Hirt, A Conspiracy of Optimism: Management of the National Forests Since World War Two
} (Lincoln: University of Nebraska Press, 1996). 
of the "scientific" studies and projections that favored dams and hatcheries. ${ }^{67}$

When the dam planners first proposed The Dalles Dam in 1945, C.G. Davis worried that the system would destroy habitat in the entire basin. Davis, looking for partners, attended an early meeting of the Columbia River Basin Fisheries Development Association. The group of Astoria-based commercial and sports fishers agreed to oppose all future dam projects in the entire basin. In his report back to the Yakama reservation superintendent, Davis inserted his own opinion "off the record." Davis was alarmed at a speech made by Washington Senator Harold N. Jackson, who proposed a prohibition of all commercial fishing above Bonneville Dam—especially Indian fishing. "Reading between the lines I decided that he used this argument to persuade several sportsmen organizations to join the association," Davis informed Yakama superintendent L.W. Shotwell. Although the group remained committed to opposing all dams, the addition of sports fishers to the mix signaled to Davis that non-native sports and commercial fishermen still had their eyes on curtailing all, especially Indian, commercial fishing in the mid-river above Bonneville. Nowhere in the treaty did it differentiate between commercial and subsistence fishing rights, but many still focused on preventing Indians from using their treaty rights to earn income. ${ }^{68}$

\footnotetext{
67 Wilson Charley to James James, April 26, 1953, JJP.

68 Charley to James April 26, 1953, JJP; C.G. Davis to L.W. Shotwell, Dec. 18, 1945, folder 155u, box, 12, Field Agent - The Dalles, OR, General Subject Correspondence 1939 - 1953, Portland Area Office.
} 
However, the CFC's willingness to self-regulate promoted several interesting alliances. The Mid-Columbia Fishers Association, a consortium of commercial fishers and industrial canners, began to echo some the CFC's concerns in challenging The Dalles Dam. Since the 1880 s, Industrial canneries and commercial fishermen had contested the claims and scope of Indian fishing rights. However, The Dalles Dam posed such a threat to the non-native commercial interests, the association incorporated some of the very treaty rights and Indian arguments they had previously rejected. The association's finding of fact boiled down to this simple statement: "construction of The Dalles Dam would necessarily eliminate a long-standing and proven productive industry." Further, the association noted that plans for energy conservation, "efficient" atomic power, and a return to a prewar pace could altogether negate the need for a dam. Still, the association noted, if a dam had to be built, it could be moved up river, or better yet, other dams like Hells Canyon on the Snake River and Foster on the Santiam River might generate enough power. ${ }^{69}$

The association also injected what they thought were Indian concerns. They pointed to the legal and moral issues with destroying Indian fishing sites, the loss of tourism at Celilo, which they expressed as high as 1,000 a day. "Any compensation will not be just," the report stated. In later years, Charley echoed many of the points

${ }^{69}$ Mid-Columbia Fisheries Association, "The Wealth of the River: A Presentation of Fact Concerning the Salmon Industry at and Near Celilo Falls on the Upper Columbia River...” Typed manuscript, Sept. 1945, Oregon Historical Society Research Library, Portland, Oregon. 
articulated by the association—although he had a much more nuanced view regarding treaty rights. Ideas like the relocation of the dam and questioning energy demand remained embedded in his routine letters to James. It is unclear whether Charley picked up these points from the association or vice versa. But in 1946, Charley and the association determined that following the U.S. Fish and Wildlife's recommended ten-year moratorium on dam building might ameliorate these issues - giving time to find a viable solution for fish passage hatchery development. ${ }^{70}$

What is most telling about the finding of fact is that it suggests that commercial and Indian fisherman on the mid-river both looked for congressional support of the dam moratorium. However, this alliance soon fell apart for political reasons. The Vanport flood of 1948 and the consolidation of lower Columbia River fishermen and hatcheries, which quickly and ironically blamed Indians for destroying salmon runs, gave Congress the necessary political capital to push forward a massive multi-dam development planincluding The Dalles. The final authorization for The Dalles Dam would still take several more years, but it was becoming clear that the dam might achieve the overall goal of many non-native interests: to curtail Native fishing rights.

In 1948, sensing the buildup of political capital for The Dalles Dam, Wilson Charley, now chairman of the CFC, began discussing how to sue for an injunction. Citing the Yakama Nation's concurrent suit against McNary Dam, Charley noted that to find a

${ }^{70}$ Ibid; William G. Robbins, Landscapes of Conflict, 47 - 76. 
figure for damages, they would need to gather statistics of the Indian catch at Celilo and other fishing grounds that The Dalles Dam would flood. Charley noted the relative ease in calculating the commercial catch because most canneries already did this for accounting purposes. However, the subsistence catch was far more difficult to quantify. "Indians do not like to give out information on poundage caught for subsistence needs.... guess work is no good in court... We should figure someway to get that record," Charley stated before the CFC. Again, the complex and overlapping identities of River Indians, reservation enrollees, and Celilo residents made many Natives skeptical of Charley's call for a centralized poundage statistics. Could these figures be used against fishermen? The generalized statistics said nothing of the other aspects of the falls that would also be lost — the spiritual, social, and historic. Justifiably, past court cases and the willingness of the states to continue to combat Indian fishermen were likely at the root of many Indians skepticism over Charley's plan. Often, there was no realistic difference between commercial and subsistence catches. Numerous times, Charley sold fish to canneries to buy fuel to drive up into the mountains for berry picking. Often, Indian fishing families could trade a salmon for commodities within their own culture, but as Myra Sohappy stated years later, it was awful hard to get the gas station attendant to fill the tank when you slapped a salmon on the counter. In other words, selling fish commercially was often a necessary means of subsistence. Although Charley dreamed of a thriving commercial 
Indian-run cannery, the fact was, most Indigenous fishers were still impoverished. ${ }^{71}$ Rhetoric constructed reality. Anticipating the potential lawsuit, the states of Oregon and Washington started conducting their own studies of the commercial and subsistence catch. Washington State Fish and Game Director Milo More looked to the dam as a way to finally rein in Indian commercial and subsistence fishing. On the other side of the river, the Oregon Fish Commission began its own study of the dip net fishery as early as 1947 . For both states, determining the Indian share of the catch was necessary for a simplified management plan, which included an Indian fish tax. Resolute in imposing "drastic reductions for the purposes of conservation" on the "unregulated Indian fishery," the Oregon commission spent years gathering numbers by peering through binoculars at Indians as they fished. Steeped in the political rhetoric of the time, the Oregon commission concluded that the fishery would remain unregulated and that Indians were incapable of implementing their own conservation measures. In the report to U.S. Fish and Wildlife Service, the commission added some statistics to support state intervention. Gathering figures by peering through binoculars, officials surmised that Indians in 1952-1954 had taken 28 percent of the annual catch in violation of state law. Once submitted to the USFWS, the ACOE began recording the names, poundage, and

\footnotetext{
71 Minutes of Regular Meeting of the Celilo Fish Committee, April 1, 1948, folder 155, box 12, Field Agent-The Dalles, OR, General Subject Correspondence 1939 - 1953, Portland Area Office.
} 
tribal affiliations of fishermen so they could develop a figure to offer cash settlements for Natives' fishing rights. ${ }^{72}$

Seeing the state officials off in the distance stare at him through binoculars, Wilson Charley pleaded for fairer regulations. At a 1949 CFC meeting, he argued for broadened and expanded CFC regulations to combat state encroachment. Charley favored turning over any Indian violating CFC regulations to the committee, instead of state authorities. This, of course, would require an Indian Fisheries police force. For the police force to have authority, these regulations and procedures would need the approval of the Department of Interior and the Commissioner of the Indian Service-who appeared uninterested. Charley's plan boiled down to writing regulations that favored what Indians, not the states, wanted and which were grounded in real numbers not distant observations from the road. "That fact has been overlooked for all of these years," said Charley. He continued, "if the Indians do not adopt and enforce rules and regulations regarding the fishing by Indians, then the States will do it, to the disadvantage of the Indian."73

It was not all Charley's fault that he was unable to convince the CFC to pass

\footnotetext{
72 Robert W. Schoning, Theodore R. Merrell, and Donald R. Johnson, "The Indian Dip Net Fishery at Celilo Falls on the Columbia River" (Portland: Oregon Fish Commission, 1951); U.S. Army Corps of Engineers, "Summary Report on The Indian Fishery at Celilo Falls and Vicinity, Columbia River 1947 1954," 1955, Stream Net Library, accessed January 5, 2017, http://docs.streamnetlibrary.org/SummRepCelilo1947-54.pdf.

73 Minutes of Regular Meeting of the Celilo Fish Committee, April 1, 1948; folder 155, box 12, ibid; Quote from, Minutes of Regular Meeting of the Celilo Fish Committee, Sept. 1, 1949, ibid.
} 
enforceable regulations. While the complexity Columbia River Indian identity led to some of the internal conflicts in the CFC, there were several other significant external factors. At the center of the plan's failure is the colonial system to which Charley and every Indian leader had to operate. Even if he could have sold the Indian fish police idea to the $\mathrm{CFC}$, Congress and the BIA would never have authorized or funded it - much as they had with his earlier refrigeration proposal. Instead, Congress buried piecemeal funding authorizations to dam projects in the complicated and highly secretive Senate appropriations committee meetings—-held behind closed doors. Charley began spending hours every day combing through pages of congressional and senate budget reports trying to study how to fight the dam, but unable to get his concerns before the closed-door meetings, he stood little chance of getting the ear of a committee member. The legal system also was ill-equipped to consider the overlapping identities and needs of the CFC. Lamenting on the difficulties of working with incompetent BIA appointed counsel, Charley noted, in 1855 "my forefathers done a good job and if we had a good attorney [today], that damn dam would never be constructed."

Just as Charley began to feel swamped in a sea of congressional documents, he received help. Jimmy James, who had first written to Alex Saluskin offering to help publically oppose The Dalles Dam, quickly became an important ally in the next phase of the fight. Working directly with Charley, James obtained copies of senate bills and traced politician's maneuverings. Charley became less interested in working with the CFC and 
now worked as a Tribal Councilman, vowing to "defend my nation from any institution or influence." Pivoting away from the CFC he declared, "stand your ground regardless of the odds. In the long run a person will win out. We can see now that this is only a stall to gain more time for another complication." 74 The CFC had been unable to get its concerns up the BIA bureaucracy and to the Army Corps of Engineers - essentially proving Tommy Thompson's initial fears. This left Charley backed into a corner. "So I tried to turn elsewhere," wrote Charley as he reflected on the pivot away from the CFC. "I tried to ask the Yakima General Council in 1948 to send the tribal fish committee, because the Celilo Fish Committee has met many times with the Area officials and were told they could not help us...that is why we turned to the General Council of the Yakima Indian Nation, because we had only one place left to go."75

\section{Federal Termination}

The next complication arrived in 1953. That year, Congress formally unveiled a new direction in federal Indian policy. Called "termination," House Concurrent Resolution 108 (HCR108) slated five tribes specifically, and all tribes in California, Florida, New York, and Texas to be "freed from Federal supervision and control and from all disabilities and limitations specially applicable to Indians." Additionally, the resolution called for "all other offices of the Bureau of Indian Affairs whose primary

\footnotetext{
74 Charley to James, Sept. 7, 1954, folder 42, box 1, JJP; Charley to James, Nov. 22, 1953, JJP.

75 Charley to James, July 16, 1958, folder 42, box 1, JJP.
} 
purpose was to serve any Indian tribe or individual Indian freed from Federal supervision be abolished.” HCR 108 was just the beginning salvo. Termination policy contained numerous federal laws to cut loose federal oversight and "free" Indian people. However, in so doing, termination also opened up tribally protected resources and industries to private developers, state regulation, and taxation. ${ }^{76}$

If HCR 108 freed the tribes from federal supervision, Public Law 280, enacted just two weeks later, freed state and private interests to impose their will on reservation Indians. Effectively, the law empowered six western states to assume legal jurisdiction over Indian reservations not yet terminated. Sections 6 and 7 of the act allowed states to amend their constitutions to extend local laws onto tribal lands as well as lifting any prior prohibitions to do so. President Eisenhower had apprehension over the law's effect on tribal self-governance because it transferred the oversight away from the federal government to individual states, and, especially because legislators did not "ascertain the wishes and desires of the Indians." Despite Eisenhower's concern, the president signed the bill and prompted Congress to make amendments for tribal consultation at a future date. ${ }^{77}$

\footnotetext{
76 Paul Finkelman and Tim Alan Garrison, "Encyclopedia of United States Indian Policy and Law," House Concurrent Resolution 108 (1953) (Washington, DC: CQ Press, 2009), http://knowledge.sagepub.com/view/encyclopedia-of-united-states-indian-policy-and-law/n278.xml.

${ }^{77}$ Public Law 83 - 280, August 15, 1953; Paul C. Rosier, Serving Their Country: American Indian Politics and Patriotism in the Twentieth Century, Reprint edition (Cambridge, Mass.; London: Harvard University Press, 2012), 163.
} 
HCR 108 and PL 280 had come at the worst time. Charley and Yakama Council Chairman Alex Saluskin were busy traveling across the country trying to persuade congressmen and Indian rights advocates to cut off funding for The Dalles Dam and appropriate funds for the tribe to run its own conservation program — this hardly fit the mold of termination policy. Although construction began in 1952, Charley remained optimistic that they could convince the senate appropriations committee to cut the funding to the next phases of construction. However, state encroachment had long been a concern for Charley, and the potential effects of federal termination policy affirmed his already deep concerns. ${ }^{78}$

With termination, the states were cracking down on Indian fishing even harder. In the summer of 1953, James inquired why a non-Indian fish buyer had been arrested at Celilo for purchasing an Indian's fish out of season-especially because the Indian fisherman had been using this usual and accustomed fishing rights. Why did it matter what Indians did with the fish they had the treaty right to catch? A reply to James by W. Barton Greenwood, Acting Commissioner of Indian Affairs, left open the possibility for state intervention, specifically citing the Tulee decision and Public law $280 .{ }^{79}$ But Yakama Tribal Chairmen Alex Saluskin felt Public law 280 was "wholly one sided." The tribe "requests that sections 6 and 7 be stricken out," he demanded. "An amendment is

\footnotetext{
78 Charley to James, March 6, 1954, folder 42, box 1, JJP

79 W. Barton Greenwood to James, 2 Nov. 1953, folder 57, box 1, JJP.
} 
requested that Indian tribes have optional rights to come under State laws or remain under their own tribal and Federal Laws." He continued, "government withdrawal at the present time would be disastrous to our progress, socially and economically. We are just beginning to operate our timber. We can now send our young people to schools of higher learning but it will take another 100 or more years before our people will be able to cope with other citizens on an equal standard of education and business." He further noted that the tribe's treaty-protected rights made them exempt from state taxation. Lastly, he concluded that HCR 108's rapid move to dissolve their treaty would place "most of our Indian people in the slums, skid roads, and jails - most of our older people on welfare." Responding to Saluskin, James fired off several letters to the President of the United States, the governors of Oregon and Washington, and more moderate termination supporters like Senator Barry Goldwater, pleading for their intervention. While some of the politicians replied with sympathy, they all dodged the matter. ${ }^{80}$ James had tried to get Charley a personal meeting with President Eisenhower where he hoped Charley could present the Yakama's treaty concerns. A direct reply to Wilson Charley from the president's special assistant took a more devastating tone. Citing Lonewolf v. Hitchcock (1903) and Ex parte Webb (1912), the White House Assistant Charles Willis Jr. noted, "It is well established by decisions of the Supreme Court that Congress does have the power to enact legislation in conflict with treaties."

80 Alex Saluskin to James J. James, January 26, 1954, folder 46, box 1, JJP. 
Not only would termination allow the states to assert power over the Yakama, but also the White House was indicating that it supported Congress's power to abrogate the 1855 treaty. ${ }^{81}$ This was the most alarming possibility for Charley as his entire strategy rested on the sovereign sanctity of the U.S. and Yakama Nation's 1855 treaty. By mid-1954, the situation looked worse than just losing some fishing grounds to The Dalles Dam. It was looking more like the federal government wanted to abandon the 1855 treaty, open up the tribes' land and resources, and subject Indians to state policies that ignored their reserved rights and customs.

\section{Fighting The Dalles Dam}

The Dalles Dam did much more than flood Natives' traditional fishing sites, it completely reordered social and political space along the river. Charley saw the dam as a carefully orchestrated artifice to finally dispose of his fishing rights. The rollout of the dam proposal in the 1950 s in such close proximity to termination policy both added to the existing efforts targeting Indian fishing. "The states will do everything in their power to make state laws to stop the Indians completely from all fishing in the Columbia River," wrote Charley as he began to plan his next strategy in adapting the fishery. Charley’s advocacy now relied more on his status as an enrolled Yakama. This was specifically because the BIA had tried to get all the tribes within the CFC to "agree to the building and construction of the Dalles dam," noted Charley. It was in this particular meeting

\footnotetext{
81 Charles F. Willis, Jr. to Charley, 13 July 1953, folder 42, box 1, JJP.
} 
where he and other members "stood and said we would fight the dam separately under our own treaty merits as we interpret our treaties individually." The resulting tribal protests were mixed: The Umatilla and Warm Springs tribes accepted an Army Corps of Engineers (ACOE) settlement in 1952, while the Yakama and Nez Perce held out for several more years. ${ }^{82}$

Reticent to accept any settlement funds, Charley looked toward a long-term strategy if he could not stop The Dalles Dam. "When we keep on fishing at Celilo after the completion of said dam...then we can put a claim to the government for the complete loss," noted Charley. Primarily, he wanted to make sure that he and future generations of Natives would continue to have rights to fish the river. The ACOE's simple lump sum settlement, agreed upon before the damage was done, was not sufficient in his eyes. Charley continued, "The record will show that the salmon industry is in round figures at $\$ 500,000,000 \ldots$ now, in the next million years what would be the damage done?" Unwilling to negotiate with the ACOE, Charley believed that it was "unconstitutional for a minority group to give up earning power, which is sure cash regardless of depression, to some group that already has permanent income." Instead, Charley proposed that Congress write a law giving the Yakama a portion of the profits from the dam for perpetuity. For whatever reason, Congress was unwilling to take this direction, but it

82 Charley to James, Jan. 29, 1955, folder 42, box 1, JJP; Charley to James, April 1, 1956, folder 42, box 1, JJP; Barber, Death of Celilo Falls. 
shows that at least Charley would be willing to negotiate if the terms were favorable for the tribe in the long term. Additionally, it affirmed his suspicion that "no one will help us out on the Army Engineers side to witness and prove what is said will be true 20 years from now." 83

Charley directed his fellow Tribal Council members to hold off on any settlement. He went to work studying every fishing related bill that Congress or the states introduced, consuming hours and hours of his time. Jimmy James helped procure hundreds of pages of the Congressional Record, and the two combed the papers to study the ways to foil the state and federal onslaught. Additionally, Charley spoke with his elders about the details of the 1855 treaty and asked "questions on customs, places, and how much fish caught." 84

There is little evidence of these conversations, but it is apparent that Charley continued to believe that the tribe needed to take matters into its own hands and that he was willing to embrace conservation as a resistance strategy and a way to affirm tribal sovereignty:

We have to make some kind of ordinance here (at Celilo). If we don't the white man will want to take over soon... We love what mother nature puts here for us to consume, that is why we cherished conservation since the time of

83 Charley to James, April 15, 1954, folder 42, box 1, JJP; Charley to James, Jan. 17 1955, folder 42, box 1, JJP; Schoning, et. al., "The Indian Dip Net Fishery," 33.

84 The individual pieces of congressional records requested are too numerous to cite here, but they could number at least a dozen a week. Just to illustrate the volume, in 1955, Senator Wayne Morse noted that requests had become such a burden for his staff he would no longer supply copies to James. Charley to James, Jan. 17, 1955, folder 42, box 1, JJP. 
creation. For we know that if people take for themselves now, what will all the people one hundred years from now have?

[We] have a treaty in perpetuity to fish at all old and ancient sites or stations and we can take that right and fish below Bonneville Dam like we have here at Celilo Falls, since time immemorial without state and federal regulations, only governed by the laws of mother earth and the descendants of this mother earth; Amen. ${ }^{85}$

What Charley was also suggesting was that regardless of the outcome, he would ensure that Indians continued to fish. If the state and federal government would not recognize the sovereignty of the tribe and treaty-protected rights, then he was willing to fish and get arrested to test it in court-just like his ancestors had. "Let us legislate before the dam is completed.... All those that will fish from now until the [state] season opens will be arrested," wrote Charley as he prepared a resolution defining the tribe's own fishing regulations.

For the meantime, Charley felt there was plenty of work trying to persuade state and federal congressional representatives to recognize tribal regulations. Recalling how tribal members convinced the Washington state legislature to allow Yakamas to fish at Prosser Falls in 1921, Charley drafted an amendment to Washington House Bill 74, trying to introduce language giving treaty Indians an exemption from fishing close to fish-ways. He hoped to get a similar bill before the Oregon legislature. House Bill 72 "should also exempt Indians...get me copies of these fish commission bills. That way we can study them better," Charley directed James. Noting his upcoming hearing in

85 Charley to James, April 15, 1954, folder 42, box 1, JJP. 
Olympia, Washington, Charley noted, "Maybe we can ask for a hearing [in Salem, Or.]... I am afraid we will not get it because the Indian is not wanted to be heard in committees like the Fish and Game Commission."86

Despite the overt and covert prejudice from legislators, Charley continued to pressure state authorities. "We got to watch these things, there is always something hidden in the laws enacted by the shrewd law makers," noted Charley as he encouraged James to keep an eye out for future bills. It was complex work. Some laws "may have nothing to do with Indian people on the face of it but if all the people could look under the surface of it, many laws would not always be enacted," wrote Charley as he noted the need for greater transparency within the legislatures. What is also clear from Charley's combing through various bills was that both states were favoring commercial and sport fishers at the expense of Native rights. However, suspiciously hidden in bills, Charley kept a careful eye for any "law giving authority to one body or group of people like the fish commission." 87

Trying to catch every bill and amendment must have been exhausting. While he let James assist a great deal, the task was too large for the two men. Even if they could carefully comb every piece of legislation, it was unreasonable to expect two men to catch things and respond in time. They had to study federal bills and write to senators and

\footnotetext{
86 Charley to James, Jan 27, 1955, folder 42, box 1, JJP.

87 Charley to James, Feb. 8, 1955, folder 42, box 1, JJP.
} 
representatives in far away states, as well as the local Oregon and Washington state legislatures. Nonetheless, Charley remained confident and began traveling, requesting meetings with politicians. Crisscrossing two states, Charley frequently drove to Seattle and Tacoma, returned to Toppenish, and was off to Portland, Salem, and back to Celilo, all within a day or two. On these trips, Charley came to rely heavily on his small cabin at Lone Pine as it gave him a central place to grab a quick nap and hammer out a few letters by candlelight. What is most impressive is despite all his traveling, he still managed to get a few days to fish and visit with other Columbia River Indian families. Indeed, he was an elected representative of the Yakama Nation, but he also tried to maintain his relationships with the larger Native community. He was a very busy man. ${ }^{88}$

Frequently, Charley needed to be in two places at the same time. This was the case on July 23 of 1954. Planning to attend the meeting of the Oregon Sportsman's Association, Charley wanted to raise his concerns before the group that had "been interfering with us at Celilo and other fisheries sites." At the same time, the Army Corps had announced that they would meet with the Yakama Tribal Council that day. Quickly studying the corps current civil appropriations report, he was alarmed not to see the tribal resolution condemning the dam. Charley had spent the past few months drafting a tribal resolution, and the tribe had spent money sending members back to Washington D.C. to

88 Tracing Charley's travels is possible because he indicated where he was writing from and where James should forward a reply. In numerous cases, Charley would send James Western Union telegrams as he traveled from meeting to meeting, then, letters to politicians followed 
present it. "They do not put resolutions [like this] in the record that object to the building of the dam because they want their own way and what other people say don't mean a thing for they are in power," wrote a frustrated Charley. Canceling his meeting with the Sportsman's Association, he decided that it was more important to get the tribe's objection on ACOE records. ${ }^{89}$

However, Charley regretted missing the Sportsman's Association meeting. After he had returned from his ACOE meeting, he opened a forwarded letter from James, which illustrated how the association partnered with the Oregon Fish Commission. According to Charley's summary, the commission pledged to support non-native sports fishers along the Columbia. The commission viewed Indian treaty rights at offreservation stations as not "exclusive rights, but joint rights with non-Indians for fishing in the same area." Charley did not dispute non-native rights to fish; rather he felt that even his joint rights were imbalanced to favor sportsmen. Learning of a future meeting between the Oregon Fish Commission and The Dalles Rod and Gun Club, Charley became adamant that he attend and "present the Indian's point of view toward selfdisciplining non-Indian anglers." 90

On a rainy September day, Charley traveled to Seattle for a gathering of Sportsmen's Associations from all over the country. Charley had been to many salmon

${ }^{89}$ Charley to James, July 17, 1954, folder 42, box 1, JJP. ${ }^{90} \mathrm{Ibid}$. 
barbecues, but none like this. As one of the few Indians present, it must have been extremely awkward to speak to so many anglers that blamed Indians for wasting fishespecially as anglers feasted on seemingly endless platters of grilled salmon. "I told the sportsmen that we must go before the legislatures and iron out our differences and come to some understanding," wrote Charley as he reflected on the barbecue. He hoped engaging the sportsmen might turn an enemy into an ally. Working together, he hoped, "we will know what is ours and then we will concede to be commercialized." At the same time, the concession was a careful play to maintain Indian fishing for generations: "to a whiteman there must be regulation for that is the only way he understands or obeys. Without regulation the whiteman does not know what conservation means." Charley turned conservation, a word that regulators used against him, on its head by appropriating it at the tribal level. ${ }^{91}$

One month later, Charley was picking apples in Hood River to earn some cash when he had a conversation with a local white fisherman who was protesting an amendment to the Oregon legislature. The bill would reportedly hurt small gillnetters along the mid-river, but what intrigued Charley was that the man's approach to using the initiative process to pass citizen legislation. It concerned him that the Oregon Fish Commission continued to listen to sportsmen's concerns over his own. Reflecting on both Oregon and Washington Fish Commissions, Charley stated, "they only hear one side.

91 Charley to James, Sept. 20, 1954, folder 42, box 1, JJP. 
That is why they give the sportsmen the right to fish with hook and line.... Our treaty does not read that we cannot fish with hook and line." Indeed, article three of the treaty said nothing about limiting fishing technology. Speaking about this specific article, Charley noted, “it's might broad and it takes a lot of territory. I am proud of my forefathers, they outsmarted the whiteman when they made that treaty." Despite his significant work to align with sportsmen, both states and the various federal regulatory agencies continued to dismiss Charley's efforts to fight the dam and protect the fishery. ${ }^{92}$

\section{A Five Member Federal Fish Commission}

Ever persistent, Charley continued attending the Oregon Fish Commission and Washington State Fisheries Department meetings. While it could be a coincidence that both states often held their meetings at different places on the same days, this fact was very upsetting to Charley. Still, he could only attend one meeting at a time. Overall, his presence at state level meetings proved fruitless. ${ }^{93}$

However, in the spring of 1956, Charley saw a glimmer of hope that might give Indian fishing rights protections on the federal level. Charley read of a recent court case that challenged Public Law 280, which had given the states' power to regulate tribes. Federal district court Judge Gus Solomon, a judge sympathetic to Indian treaty rights,

\footnotetext{
92 Charley to James, Oct. 5, 1954, folder 42, box 1, JJP; Charley to James, March 25, 1956, folder 42, box $1, \mathrm{JJP}$.

93 Charley to James, June 9, 1654, folder 42, box 1, JJP; Charley to James, Aug. 19, 1954, folder 42, box 1, JJP; Charley to James, March 26, 1956, folder 42, box 1, JJP.
} 
ruled that the Oregon State Fish and Game Commission could not impose state hunting license fees to Indians on the recently terminated Klamath reservation, even though Congress terminated the tribe. The ruling affirmed Charley's hope that treaty protections might stand even if the Yakama were terminated or, more significantly, if The Dalles Dam were completed. Reading of Solomon's decision, Charley quickly wrote to Jimmie James and asked him to inquire how the BIA might react. Charley also began investigating Washington Senator Warren G. Magnuson and California Senator Thomas H. Kuchel's forthcoming bill. As Charley understood it, their legislation would take Columbia River fisheries completely out of the control of the U.S. Fish and Wildlife Service and establish a "five-member commission to control all phases of U.S. Fisheries." Empowered that treaty rights would trump public law 280, Charley wanted to be on the prospective federal fisheries commission. ${ }^{94}$

"The Corps of Engineers are beginning to understand why we opposed the dams," wrote Charley as he outlined how the states and federal fisheries biologists had failed to create viable fish hatcheries upriver from Grand Coulee. He continued, "we all know that is a waste of money, because biologists, money and scientific study cannot replace mother nature...it raised salmon that are strong and sturdy.... Salmon raised by hatcheries are not that way." In his mind, an Indian fisherman needed to be on the five-

94 Charley to James, March 5, 1956, folder 42, box 1, JJP; “Indians Upheld on Hunting Rights" Spokane Daily Review, Mar. 1, 1956; Harry H. Stein, Gus J. Solomon: Liberal Politics, Jews, and the Federal Courts (Portland: Oregon Historical Society Press, 2006); Karson, Wiyaxayxt / Wiyaakaa'awn / As Days Go By. 
member commission for the good of all parties involved. Willing to "use the white man's method of catching fish... does not mean we have to abide by their laws when we have laws of our own," wrote Charley. The language of the treaty gave him a right to fish "in common with the citizens of the territory" meaning, that those tribal regulations were quite possibly more effective than the states. Unfortunately for Charley, Congress scrapped Magnuson's bill. ${ }^{95}$

\section{Still misunderstood}

As a Columbia River Indian fisherman and as a Yakama Tribal Councilman, Wilson Charley confronted racist and bureaucratic impediments that confined his leadership in protecting fishing rights. The Dalles Dam was just one act in a century's long struggle to compel the United States to live up to the reserved fishing rights in the 1855 treaty. Turn after turn, non-natives recast their legal and political power to assault Indian fishing rights. Yet, during Wilson Charley's tenure, he met non-natives at every turn and used conservation as a tool to assert that the treaty rights would still apply to the changing river.

While The Dalles Dam controversy was but one episode in this larger struggle of Indians advocating for their fishing rights, there were several significant aspects to Charley's leadership which were amplified during the dam controversy, as the following chapters will illustrate. Charley's efforts to engage with non-native commercial and sport

\footnotetext{
95 Charley to James, April 8, 1956, folder 42, box 1, JJP.
} 
fishing groups, while significant, continued to fail. Part of the reason lay in the fact that most non-natives continued to misunderstand the complexity of Indigenous rights along the river. However, early on, Charley recognized that he needed a larger community of nascent environmental activists and conservation leaders. In the midst of his struggle to protect fishing rights, Charley dispatched James J. James to help craft a larger public relations campaign. James and Charley thought if non-natives would not listen to Charley's concerns, maybe the public would if the media presented Indian leaders differently. If James and Charley could convince the public to stand up and say no to the dam, then the politicians and government administrators might fall in line. ${ }^{96}$

96 Charley to James, March 7, 1955, folder 42, box 1, JJP; Charley to James, March 3, 1956, folder 42, box 1, JJP; Charley to James, April 13, 1956, folder 42, box 1, JJP. 


\section{Chapter 2}

\section{"A Good Poker Player Will Always Fool the Other Party": Charley's Political and Public Relations Strategy}

"We [Yakama] should protect ourselves, and that part is hard work because the cards are stacked against you all the time... a good poker player will always fool the other party and that's what we have been doing all this time. There is more to The Dalles Dam than a person can see unless you are a good guesser ahead of the program."

—Wilson Charley to James J. James, December 21, 1955

\section{"The public is powerful if you approach them right and with sincere heart and honesty."}

—Wilson Charley to James J. James, March 8, 1955

Fall was always a busy time of year for Wilson Charley. However, in 1954, Charley felt a heightened urgency. It was the middle of the fishing season at Celilo Falls and dozens of Native American men lowered their long dip nets from wooden scaffolds skillfully perched over the roaring whitewater. Women were busy cleaning and processing freshly caught salmon. Visiting Indians traveled to Celilo from as far away as Idaho and British Columbia to participate in the fishing, and select families with controlled access to these scaffolds hosted the visitors. Beyond fishing, other activities such as dancing, singing, trading, gaming, and socializing had shaped families, formed inter tribal alliances, and aided cultural transmission for generations. ${ }^{97}$

\footnotetext{
97 Barber, Death of Celilo Falls; Ulrich, Empty Nets; Fisher, Shadow Tribe; Dupris, et. al., The Si'lailo Way; White, The Organic Machine.
} 
Wilson Charley wanted to publicize the festivities and invited a corps of press and politicians to the falls to build a cross-cultural coalition of voices opposing The Dalles Dam. Over the past few years many non-Indians had flocked, cameras in hand, to take home their own picture of Indians fishing at Celilo. In fact, non-natives' frenzy to photograph Indians fishing at Celilo fueled public acceptance of the dam's inevitability. However, Charley believed that with construction in its initial phases, public outcry could still stop the dam. Charley's strategy attempted to use the press and politicians to persuasively present his tribe's opposition and extinguish public acceptance of the dam.

This chapter centers on Wilson Charley's resistance to The Dalles Dam and traces how he tried to convince the public and political spheres of non-native conservation that the dam was not inevitable. Drawing parallels with successful campaigns to halt dams on rivers across the United States, Charley resisted the idea that The Dalles Dam was inevitable and sought a wide coalition of proto-environmentalists to support him. The Dalles Dam was only inevitable because both Congress and conservation community dismissed Charley by constraining tribal negotiations while simultaneously funding the dam. More significantly, the early environmental community's failure to help Charley illustrates some of the limitations of the nascent environmental movement itself. 


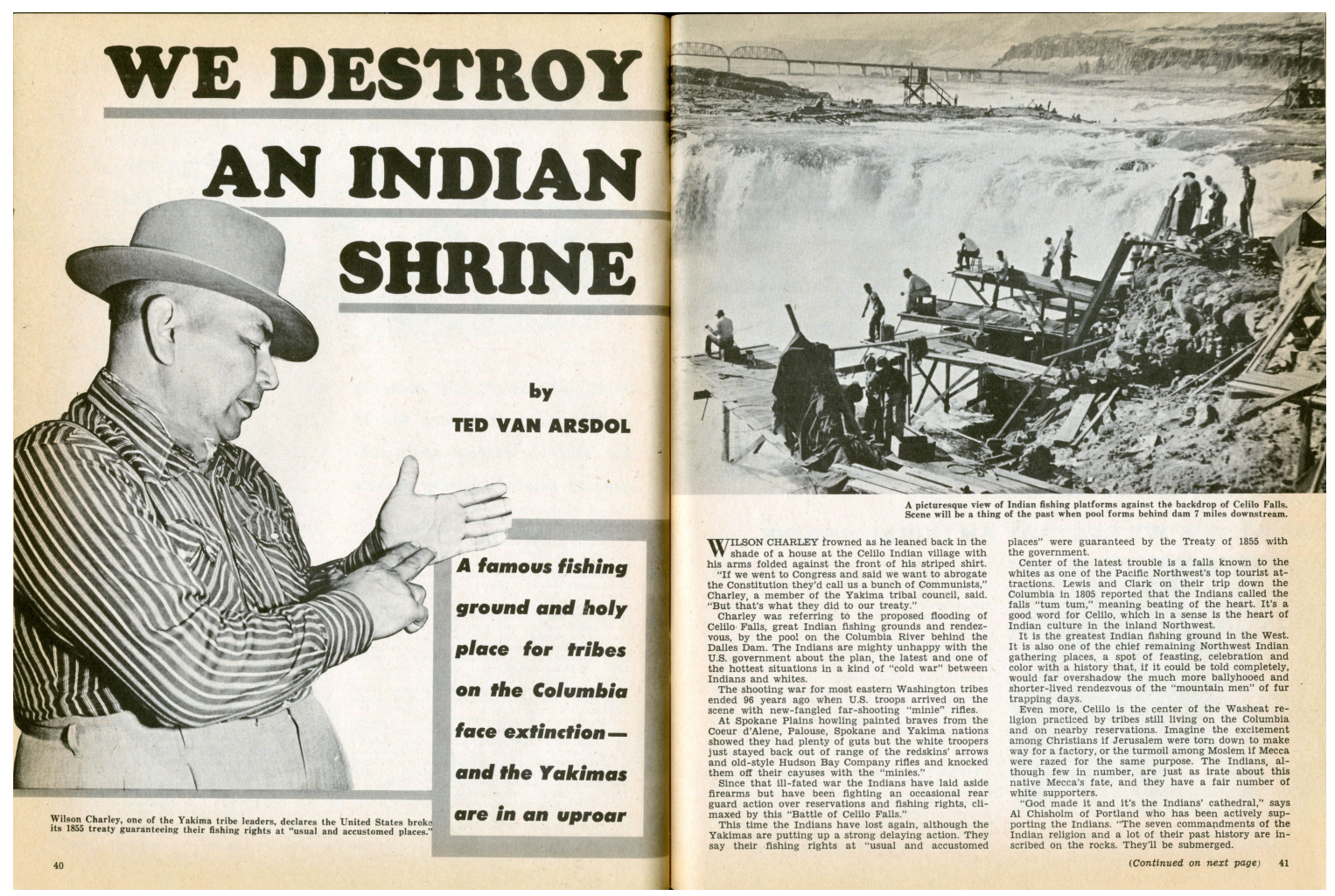

Figure 7: Charley hoped that this Man's Life article would garner non-native support for his fight by framing the destruction of Celilo as a threat to American democracy. From the personal collection of magazine collector Robert Deis.

Figure 8 (next page): Photographer Ben Maxwell captured the construction at The Dalles Dam in the spring of 1954, with only the initial pylon footings viable. Image from the Ben Maxwell Collection, Salem Public Library, Salem, Oregon. 


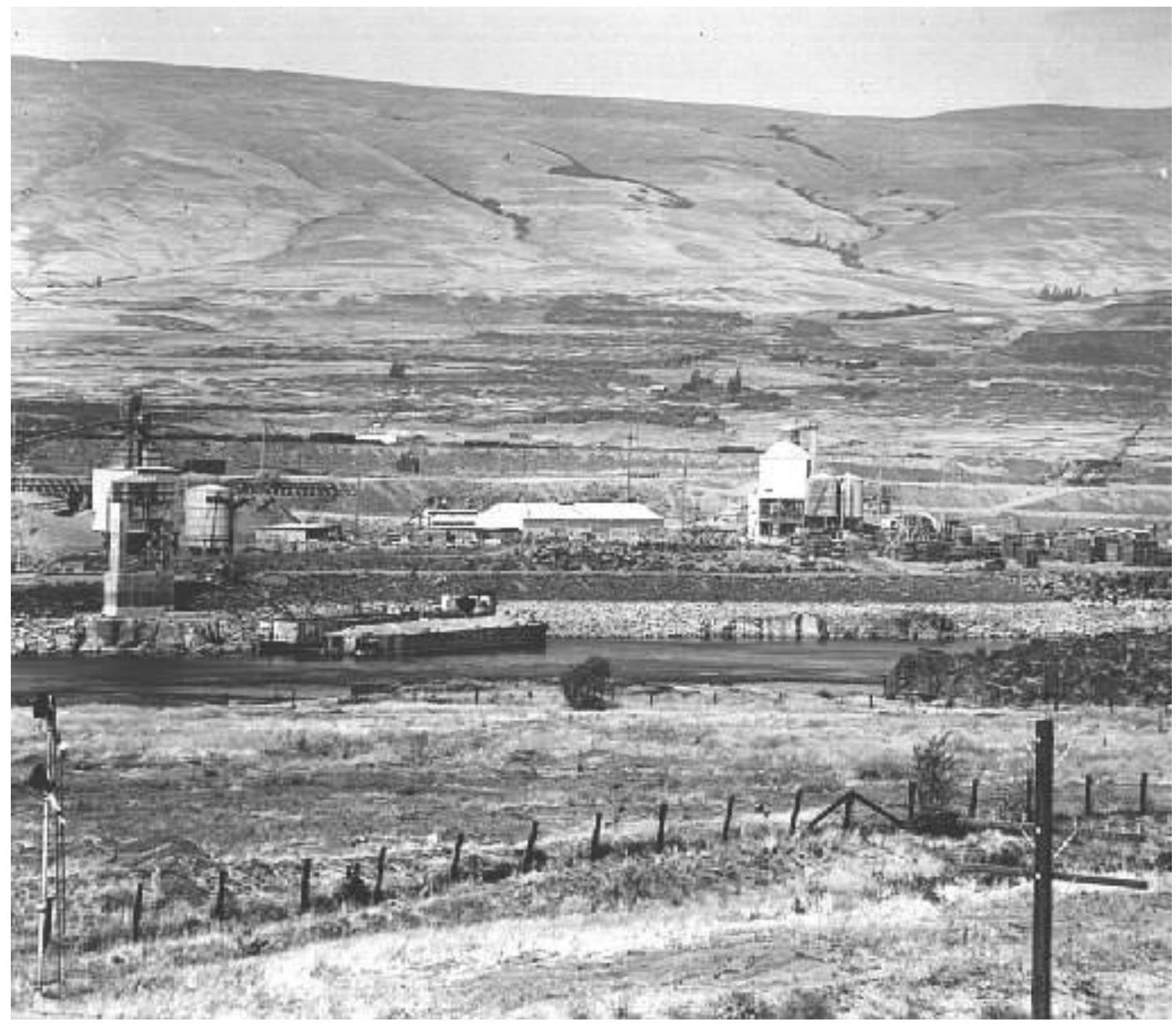

Normally, Charley would be out on his family scaffold, rope tied around his waist, dipnet in hand, and eyes on the churning boils looking for the next big salmon. ${ }^{98}$ Yet, on that fall day in 1954, Charley had other issues on his mind. Instead of fishing, he was interpreting the significance of Celilo to a small contingent of reporters. Dressed in slacks, a well-pressed dress shirt, and fedora, Charley turned to a reporter for Man's Life, cleared his throat and said, "If we went to Congress and said we want to abrogate the constitution, they'd call us a bunch of Communists... But that is what they did to our

\footnotetext{
98 For a discussion of fishing stations as family owned property see, William L. Lang, "The Sense of Place and Environmental History" 84-85; Leibhardt Wester, Land Divided by Law; Aguilar, When the River Ran Wild!; Hunn, Nch'i-Wána, "the Big River.
} 
treaty." 99 Charley's interview and subsequent feature in Man's Life, a chauvinistic pulp and pop culture magazine, defined a deeper significance of the falls beyond the fishing and economics. The readers of Man's Life, largely middle-class white males, made the publication an ideal platform to share Charley's message with non-natives. ${ }^{100}$

The publication of Charley's feature article, "We Destroy an Indian Shrine," represents a success in his overall strategy to reach non-native audiences and oppose The Dalles Dam. It opened and closed with Wilson Charley's characterization of the Yakama's treaty rights as analogous to the U.S. Constitution, framing the issue in patriotic and anti-communist terms. Exposing what historian Thomas Borstelmann calls the "cold war color line," Charley showed largely white, middle-class male readers of Man's Life the contradiction between the fight against communism and the poor treatment of Native Americans. ${ }^{101}$ Further, the article included interviews with numerous other Indian fishermen and extolled the religious and sacred nature of the fallsespecially the connection to the Washat religion. Several pages covered the annual first salmon ceremony, the vibrant culture, and site's significance as a trade center. The article

\footnotetext{
99 Quoted in Ted Van Arsdol, “We Destroy and Indian Shrine” Man's Life 3 no. 2 (January 1955): 41. 100 For more on the history of men's adventure magazines and their chauvinistic qualities see, Adam Parfrey, It's a Man's World: Men's Adventure Magazines : The Postwar Pulps (Port Townsend, WA: Feral House, 2003); For other instances of Indian's using the media to garner support see, Smith, Hippies, Indians, and the Fight for Red Power; and Johnson Jr., "The Chinle Dog Shoots." 101 Thomas Borstelmann, The Cold War and the Color Line: American Race Relations in the Global Arena (Cambridge: Harvard University Press, 2003); Heather Fryer, Perimeters of Democracy: Inverse Utopias and the Wartime Social Landscape in the American West (Lincoln: University of Nebraska Press, 2010); Paul C. Rosier, Serving Their Country: American Indian Politics and Patriotism in the Twentieth Century (Cambridge, Mass.: Harvard University Press, 2012).
} 
also noted the "fair number of white supporters" that wanted to help save this "Native Mecca" from inundation. Yet, for all its substantive coverage, the author erroneously presented the tribe's cause and culture in a futile stasis. "This time the Indians have lost again, although the Yakimas are putting up a strong delaying action," the author concluded. At the same time, it was similar to most press coverage that supported the inevitability of the dam, and a limited and mistakenly narrow conclusion that Indians must accept a tragic loss. ${ }^{102}$

Pictured on the title page, Charley's Man's Life article was the only publication to interview him in such detail. Charley had invited dozens of other journalists and politicians all of whom ignored him. Thus, his Man's Life piece is a fitting point of departure for exploring the depths of his non-native public outreach $-\mathrm{a}$ less expected form of American Indian leadership during the 1950s. Making numerous trips to testify before Congress, drafting appeals to local politicians, and working the internal politics between the Yakama Nation and the Bureau of Indian Affairs, were important, even expected ways for a tribal leader to protect tribal interests. However, Man's Life specifically catered to a general readership of men, and it presented Charley as an

102 "Tribe Wants Halt of Dam" Oregonian, March 26, 1952; "Indians Want It Moved but The Dalles Dam Goes Ahead" Oregonian, May 10, 1953; "Pryse Plan for Yakima Payment Gets Cold Washington Reception" Oregonian, June 7, 1953; "Construction of The Dalles Dam Proceeds While Controversy Rages Over Relocation" Oregonian, May 10, 1953; White, The Organic Machine. 
articulate, masculine, and modern Native American leader. Unfortunately, other journalists and politicians decided not to cover the event. ${ }^{103}$

Charley framed Indian culture in terms relevant to non-natives specifically to protect his tribe's treaty rights - a clear form of Indigenous survivance. ${ }^{104}$ With limited resources to fight the dam, Charley knew that he needed to make non-natives empathize with his perspective. To this end, Charley used friendships with people outside his tribe to overcome the limited resources of the Bureau of Indian Affairs. 105 "May the supreme being help us both in this grave cause of ours," Charley wrote to James J. James as they requested assistance from politicians, editors, writers, and various conservation organizations to stop The Dalles Dam. ${ }^{106}$

Seeking to make Celilo a national issue, Charley situated his resistance to The Dalles Dam within a larger context of conservation campaigns to stop other damsspecifically Echo Park in Dinosaur National Monument and the Hells Canyon High Dam on the Snake River. Charley studied the newsletters of conservation organizations, engaged directly with the institutions and figures from these controversies. His attempt to mirror their strategies adds a new dimension to The Dalles Dam opposition and their

\footnotetext{
103 "Three Agencies at Work to Halt Construction of Dalles Dam" Oregonian, Jan. 24, 1953; "Six Yakima Chiefs Voice Protest Against The Dalles Dam" Oregonian, Feb. 21, 1953; "Indians Pow Wow with Senator" Oregonian, March 16, 1954.

104 Gerald Vizenor, Manifest Manners: Narratives on Postindian Survivance, (Lincoln, Neb.: University of Nebraska Press, 1999); Gerald Vizenor, Survivance: Narratives of Native Presence (Lincoln, Neb.: University of Nebraska Press, 2008); Raibmon, Authentic Indians; Tonkovich, The Allotment Plot. ${ }^{105}$ Charley to James, December 21, 1955, folder 42, box 1, JJP. 106 Charley to James, March 6, 1954, folder 42, box 1, JJP.
} 
refusal to help him further points to the tensions between the environmental movement and Native American communities. ${ }^{107}$

\section{Studying Hells Canyon and the Politics of Dam Building}

As the Yakama were hard at work delaying The Dalles, Charley studied Native resistance to dam building on the Missouri and the Seneca Nation's resistance to the Kinzua Dam on the Allegany River. Studying the politics of hydropower, Charley developed a nuanced view of the interplay between federal power and private interests. Even in the 1950s, he concluded that despite the rapid growth of middle-class suburban lifestyles, dam building was not inevitable.

It was the controversial Hells Canyon High Dam where Charley saw an opportunity to play politics and fold Celilo into an already contentious debate. The basics of the controversy revolved around a proposal for a singular massive multipurpose high dam managed by the Bureau of Reclamation and the Idaho Power Company's much smaller and less expensive counter proposal for a series of single-purpose hydroelectric dams. The Bureau of Reclamation's ambitious plan to irrigate, regulate, and electrify the arid Snake River steppe was itself a cog in the Columbia Valley Authority (CVA), a massive New Deal era regional planning project. For the most part, New Deal liberals

107 Harvey, A Symbol of Wilderness; Nash, Wilderness and the American Mind; Karl Boyd Brooks, Public Power, Private Dams: The Hells Canyon High Dam Controversy (Seattle: University of Washington Press, 2006). 
supported the Hells Canyon project and the CVA, an ambitious series of projects conservatives had long opposed.

Secretary of the Interior Douglas McKay, a champion for private investor-owned utilities under President Eisenhower, had enormous influence in the Hells Canyon controversy. McKay and his main Republican ally Oregon Senator Guy Cordon had implemented "Public/Private Partnerships," a Department of the Interior policy favoring the private development of public lands and a termination of federal supervision of American Indian Tribes. Aiming to dismantle the CVA, McKay supported the Idaho Power Company's series of smaller dams on the Snake. ${ }^{108}$

The Hells Canyon dispute was so polarizing that the November issue of Life reported, "Every vote-seeker in the power conscious Northwest has had to declare himself on the dam issue." According to Life, for the most part, the divide ran "along straight political lines, Republicans for the private-enterprise low dams and Democrats for the high government dam."109 Wilson Charley supported the federal dam, hoping that it would provide enough power to eliminate the need for one at The Dalles. Not opposed

\footnotetext{
108 Ibid.; Sara E. Dant Ewert, "Evolution of an Environmentalist: Senator Frank Church and the Hells Canyon Controversy," Montana: The Magazine of Western History 51, no. 1 (April 1, 2001): 36-51; Jeff LaLande, “Oregon Voices: Oregon's Last Conservative U.S. Senator: Some Light upon the Little-Known Career of Guy Cordon," Oregon Historical Quarterly 110, no. 2 (July 1, 2009): 228-61; Robbins, Landscapes of Conflict.

109 “The Issue: U.S. or Private Dams?” Life Magazine, November 9, 1953, p. 27 - 31.
} 
to dams writ large, Charley frequently requested the Corps simply relocate The Dalles Dam upstream to the mouth of the Deschutes. ${ }^{110}$

To get a sense of the players involved in Hells Canyon, Charley attended a meeting of the National Hells Canyon Association (NHCA), a consortium of farm, labor, and public power proponents that supported the federal high dam. Charley joined the Wasco County NHCA chapter in Arlington, Oregon in early 1953. The NCHA's monthly newsletter, Hells Canyon News, criticized McKay for aiding "the power monopoly's" attack on Columbia Basin planning by supporting Idaho Power's plan on the Snake River. Eventually, NHCA took the Federal Power Commission to the Supreme Court requesting they overrule the FPC permit for Idaho Power. However, the court upheld the decision, and with McKay slowing the federal project to a standstill, Idaho Power triumphed over New Deal federalism with the completion of Oxbow Dam in 1958.111

In his looming battle against the federal dam at The Dalles, Hells Canyon exposed political fault lines that Charley could exploit. While Charley was interested in the outcome in Hells Canyon — especially because he hoped it might reduce the need for The

\footnotetext{
110 The Army Corps of Engineers and Congress dismissed moving The Dalles Dam upstream as an option. Charley to James, Sept. 16, 1954, folder 42, box 1, JJP; Grace C. Townsend to James, Oct. 26 1954, folder 49 box 1 JJP; "U.S. Reopens Tribal Deals" Oregonian, Feb. 18, 1953; Mark Fiege, Irrigated Eden: The Making of an Agricultural Landscape in the American West (Seattle: University of Washington Press, 1999); Brooks, Public Power, Private Dams, 93 - 117.

111 Hells Canyon News, January 1954, folder 4 box 1, National Hells Canyon Association, Washington, D.C. Office records, Bx 042, Special Collections \& University Archives, University of Oregon Libraries, Eugene, Oregon (hereinafter NHCA); "Hells Canyon and You... The Facts About a Crucial Moment in Pacific Northwest History," promotional brochure of NHCA, n.d, folder 3, box 2, NHCA.
} 
Dalles Dam — the Hells Canyon controversy, more importantly, demonstrated that organized groups could thwart federal plans. As agencies and political leaders came down on one side or the other, it became increasingly clear to Charley that knowing the politics of other dams could afford allies in fighting The Dalles Dam. Still, Charley was careful not to pick one side; instead, he tried to learn as much as he could before calling on someone for support. With agencies, politicians, press, and community leaders all forming camps, Hells Canyon had proven a hot button political issue and Charley wanted to incorporate The Dalles Dam into those politics. ${ }^{112}$

\section{Challenging the Need for The Dalles Dam}

As Charley dug deeper into the politics of public/private power partnerships, he became more convinced that The Dalles project was not only unneeded but would benefit war industry at the expense of Indian treaty rights. Directly engaging the Republican Party, Charley had James write letters to Senator Barry Goldwater, McKay, and Cordon, requesting they keep hydroelectric developments federally regulated and open to the public and not in the hands of private enterprise. ${ }^{113}$ Charley saw hydroelectric development at The Dalles as excessive. Although it was before environmental impact

\footnotetext{
112 “Federal Dam Seen Closer," Oregonian, Nov. 18, 1953; "Fish Agency Hits Projects: Hells Canyon Area in Protest Zone,” Oregonian, Nov. 18, 1953; “Co-op Pushes Hells Canyon,” Oregonian, Nov. 18, 1953; "Amortization Plan of Power Firm Criticized," Oregon Journal, Nov. 7, 1953; "Dana Attacks Hells Dam Issue," Oregon Journal, Nov. 5, 1953.

113 Charley to James, Nov. 4 1953, folder 42, box 1, JJP; Charley to James Oct. 4 1954, box 1 folder 42, JJP; James to Guy Cordon, April 17, 1952, folder 55, box 1, JJP; Barry Goldwater to James, Jan 11, 1954, folder 57 , box 1 , JJP.
} 
statements and mandatory public comment, Charley felt the proposal needed public hearings and open regulations. In his view, McKay and Cordon were selling smaller private dams, like Idaho Power's plan, to bolster the military-industrial complex. Their closed-door style had "kept secret...the development of the Columbia River." Charley continued, "people need to look at [Cordon] from all angles and decide we are being led into war.... See multiple [hydroelectric projects] means more electricity and means surplus material and war follows..."114 Writing in response to Charley, Charles Willis, Jr., special assistant to President Eisenhower presented a procedural reply, “The Dalles dam will go far toward alleviating recurrent power shortages in this area which have been retarding industrial and other development.... All of the people of the Columbia Northwest, including the Yakima Tribe, will directly or indirectly share in the benefits." The reply completely avoided the connection of the dam to the ongoing arms race. ${ }^{115}$

Beyond its enormous impact on fishing rights, Charley knew The Dalles Dam would have other effects on the Yakama. Despite Willis's words, the "benefits" of "wise and proper use of waterpower" would not make life better for the Yakama. On several occasions, Charley expressed that The Dalles Dam would bring "more profit to the people who make and sell the machinery" than it would to Indians and small farmers. He clarified the "many port ways will be made and paid for by the Government on [the] river

\footnotetext{
114 Charley to James, October 2 1954; Charley to James, March 7, 1955, folder 42, box 1, JJP. 115 Charles F. Willis, Jr. to Charley, July 13, 1953, folder 42, box 1, JJP.
} 
shore which will be used by all farmers to ship their wheat out to outside markets, so any farmer would fall for that." But Charley cautioned that Indians had a hard time getting credit for machinery and access to good farmland, "farming is just like playing poker[;] you've got to always have an ace in the hole, otherwise you will eventually end up broke and get deep in [debt]." 116

Not only was he skeptical of an industrial society for its effect on Natives, but past mismanagement suggested that credit consumerism could have devastating results for Indian and white agrarians alike. As Charley noted, even when Indians could practice the farming assimilation programs had taught them, Natives in the 1950s were still often restricted or outright prohibited from access to credit. Moreover, since its earliest beginnings, farming taught in Indian assimilation programs was always outdated. "We are educated to be good and wise farmers," he wrote to James, as he expressed past frustration over not also being educated on the economics and markets involved in farming. "Things would be different now if most of our people would have the help they needed then, they would have good farms and other good profitable enterprises," he lamented. On top of all this, the experiences of the Bonneville Dam suggested that the inequity of development at best put River Indians on welfare. The dam "will have over a billion income every year and the poor Indian from his resources will be penniless and

\footnotetext{
116 Charley to James, February 15, 1955, folder 42, box 1, JJP; Charley to James, March 4, 1955, folder 42, box 1, JJP.
} 
will be on [relief programs]," feared Charley. ${ }^{117}$

There had been no opportunity for the tribes to directly comment or negotiate if the ACOE should build The Dalles Dam. The passage of the 1950 Rivers and Harbors Act authorized the ACOE to initiate construction of The Dalles Dam and compelled tribal fishermen, who had little position negotiate, to comply with the Corps construction proposals. As the bill moved into Congressional debate, Senator Guy Cordon injected his own political spin. In support of the private Idaho Power dams at Hells Canyon and a federal dam at The Dalles, Cordon initially opposed the enabling bill; his long-term goal was to derail the formation of a Columbia Valley Authority and promote private enterprise. To accomplish this, he introduced an amendment to strike out any funding for a CVA and added amendments for individual state and private hydro projects. Although the former were not included in the final act, the latter provision authorized the Corps to green light The Dalles Dam while only allowing affected Native fishermen short negotiations with the ACOE Reality Division over minor personal property damages. Indeed upset, President Truman signed the 1950 Rivers and Harbors Act, noting the act's shortcomings, "I urge that the Congress reconsider this matter ... and authorize the missing pieces of the Army-Interior Columbia Basin plan.... I urge the Congress in the

117 Charley to James January 17, 1955, folder 42, box 1, JJP; Charley to James, November 20, 1955, folder 42, box 1, JJP; for the devastating effects of termination see Wilkinson, Blood Struggle; Ulrich, American Indian Nations from Termination to Restoration, 1953-2006; Wester, Land Divided by Law. 
future to avoid authorizing projects which have not been thoroughly considered or which do not meet sound standards for river development work."118

Senator Guy Cordon's role in passing the 1950 Rivers and Harbors Act solidified that he was Charley's political nemesis. Cordon's amendments killing Hells Canyon were less of a concern. Instead, it was the fact that Cordon supported legislation that trapped the tribes into negotiating with the Corps (instead of with Congress or the BIA) without even consulting the CFC or the Yakama. It upset Charley that the law gave the Yakama "no way out whether we make any kind of agreement or settlement that law still prevails on us," and seemed to disregard the specific articles of the Yakama Treaty of 1855 and the tribe's sovereignty. ${ }^{119}$

Charley understood that the Yakama could take the ACOE to court because The Dalles Dam would violate Natives' access to usual and accustomed fishing stations under the 1855 treaty. Fearing the potential for a congressional act abrogating the treaty, Charley instead opted to secure political support for the Yakama and tried to keep interpreting the treaty out of court or in the hands of Congress. Indeed, Cordon had backed the Yakama into a corner, but Charley had a new strategy. ${ }^{120}$

\footnotetext{
118 "Rivers, Harbors, and Flood Control Act of 1950," Congressional Quarterly Almanac, accessed January 5, 2017, https://library.cqpress.com/cqalmanac/document.php?id=cqal50-1375741.

119 Charley to James, March 10, 1955, folder 42, box 1, JJP.

120 Charles F. Willis, Jr. to Charley, 13 July 1953, box 1, folder 42, JJP; Prucha, The Great Father, 29596; Mike Townsend, "Congressional Abrogation of Indian Treaties: Reevaluation and Reform," The Yale Law Journal 98, no. 4 (1989): 793-812.
} 


\section{Senator Cordon's Reelection}

Senator Cordon was up for reelection in 1954 and Wilson Charley wanted him out of office. Democrats clung to Cordon's role in the "Hell's Canyon Giveaway" to Idaho Power, but Charley was more upset at Cordon's role in the 1950 Rivers and Harbors Act. Given the heated partisan political rhetoric around private power, and Cordon's support for it, Charley looked for political allies to oust Cordon.

Richard Neuberger, one of the Pacific Northwest's most prolific writers, began working with Charley in 1952 and became his long-term ally. Neuberger had coined the term "hells canyon" and given the remote canyon national significance in his early conservation writings - publications that James and Charley read. ${ }^{121}$ In 1953, Neuberger, then an Oregon State Senator, was hard at work trying to pass a memorial in the statehouse condemning the flooding of Celilo Falls. However, because of a procedural rule change, the senate president did not allow Neuberger to introduce the memorial. Neuberger told James he "was particularly disturbed because...the House Rules Committee put in a resolution praising the Harvey Machine Company, which intends to use the electricity to be generated by the dam which will inundate Celilo Falls." Neuberger continued, "I mentioned on the floor...the fact that there seemed to be one set of rules for the king and another for the people - that the rules were lifted in the House to

121 Richard Lewis Neuberger, Our Promised Land (New York: Macmillan, 1938); Richard Neuberger, They Never Go Back to Pocatello: The Selected Essays of Richard Neuberger, ed. Steve Neal (Portland: Oregon Historical Society Press, 1989). 
accommodate the Harvey Machine Company but the same rules in the Senate were used to keep out the Celilo Falls memorial.” Unfortunately, Neuberger's memorial was never heard, but the episode confirmed Charley's suspicion that the dam would further industrialism over others, especially Indians. More importantly, Neuberger, James, and Charley had solidified a working relationship that would continue for years. ${ }^{122}$

By May of 1953, the Hells Canyon controversy was making big headlines and Richard Neuberger threw his hat in the race to unseat Guy Cordon. Neuberger's campaign materials pinned Cordon as "the senator behind the giveaways." Neuberger vowed to protect public lands and lambasted Cordon for backing tidelands oil transfers, rate hikes on public power, selling off national forest land, and supporting Idaho Power in Hells Canyon. Regarding Indian affairs, he wanted James and Charley to know specifically, "I am very much opposed to the way in which McKay wants to take the Indians out from under the protection of the Indian Bureau. I regard this as another giveaway scheme." Neuberger feared that termination was just another McKay policy favoring private profits - a point well received and shared by Charley. What is most telling about Neuberger's relationship with Charley is that it did little to serve Neuberger electorally. James, an Oregon resident, was an important potential vote for the Neuberger. However, why did Neuberger work with a Native American living on a reservation in an

122 Richard Neuberger to James, March 5, 1953, folder 24, box 1, JJP. 
opposing state? ${ }^{123}$

James had first mentioned the idea of a pan-Indian voting organization in a December 1953 letter to Charley. "Until the Indian people hold together...in voice and vote, watch[ed] when a thing [issue] came up, and consulted [with] each other, and then voted...it could be worked out."124 While Native Americans had gained full citizenship in 1924, in reality, few reservation Indians voted in national elections. This was for several reasons. Most states required literacy and physical tests to vote, and even if one could theoretically pass these tests, many Indians were justifiably skeptical of how officials administered tests and handled votes. Polling stations were also infrequent on reservations. Furthermore, many rural reservation residents were geographically isolated and lacked adequate information and resources to get to the polls. Acknowledging the constraints of Indian voting, Charley replied, "most of our people cannot read or write...[what] will it be to make people like that register?"125 In theory, James's idea of an Indian voting bloc had great potential, but in reality, it remained a major issue not addressed until the Voting Rights Act of 1965. Because most politicians did not understand the depths of Indian disenfranchisement or even important Native issues, Charley actually saw this as a strategic advantage. Suggesting to politicians that Indians

\footnotetext{
123 Richard Neuberger, "The Senator Behind the Giveaways" Neuberger for Senate Campaign Material reprinted from The Progressive, February 1954, in folder 24, box 1 JJP; Neuberger to James, May 191954, folder 24, box 1, JJP; Elmo Richardson, Dams, Parks and Politics: Resource Development and Preservation the Truman-Eisenhower Era (University Press of Kentucky, 2015) 158 - 159.

124 James to Charley, Dec. 24 1953, folder 42, box 1, JJP.

125 Charley to James, 3 April 1954, folder 42, box 1, JJP.
} 
might vote for a candidate that honored treaty rights, Charley used the possibility for a coordinated Indian vote as a brilliant bluff. 126

Voting was a key to getting sympathetic politicians in office, with or without Indians doing the actual voting. Indians "must now work in politics," wrote Charley. He saw his role as a moderator, helping his people to remember but not dwell on the negative side of what had happened before and to make politicians accountable for the future. Supporting Neuberger's campaign against Cordon, Charley noted, "if we can get this one senator [Neuberger] now, the next one will fall in line. For we will have lots of white and other nationalities on our side... they [politicians] will see the Red Race is now waking up."127 Even though the Yakama could not vote, as long as Natives bluffed as if they were voting and had non-native allies that could vote, politicians like Richard Neuberger would listen.

The day following the 1954 election, Charley returned to his fishing shed and turned on the radio to check in on the results of the Cordon-Neuberger race. Earlier that day, the papers had declared the election "too close to call" but by the evening, the final tally gave Neuberger the win over Cordon by just under 2,500 votes. In a bout of celebration and patriotism, Charley noted, "the loser [Cordon] is a poor

126 Pamela S. Karlan, "Lightning in the Hand: Indians and Voting Rights," ed. Laughlin McDonald, The Yale Law Journal 120, no. 6 (2011): 1420-53; Eileen M. Luna, "Mobilizing the Unrepresented: Indian Voting Patterns and the Implications for Tribal Sovereignty," Wicazo Sa Review 15, no. 1 (2000): 91-115; Daniel McCool, Susan M. Olson, and Jennifer L. Robinson, Native Vote: American Indians, the Voting Rights Act, and the Right to Vote (Cambridge: Cambridge University Press, 2007).

127 Charley to James, 3 April 1954, folder 42, box 1, JJP. 
sport...[Neuberger] stands for the Constitution of the United States...that has made this country free and strong." 128 Neuberger's initial support of Columbia River Indians was a big part of why Charley supported his election, and the fact that he ousted Cordon was an added bonus. The same day, James phoned Neuberger to congratulate him on winning the senate seat. Even though he knew most Natives had no ability to vote, James continued the bluff, suggesting that the Indian vote could have been the tipping point in his election. "He realizes this and said to tell you people he appreciated your vote and you may rest assured that he will see that justice is done toward Indian people," James subsequently informed Charley. James also "told [Neuberger] that if Cordon had done the honest and right thing with us, that perhaps he [Neuberger] would not have been elected, and he said he realized this." Thankful for the support, Neuberger relayed an invitation for Charley to stop in his senate office for unscheduled meetings whenever Neuberger was home in Portland. 129

James and Charley had orchestrated a political bluff, making Neuberger feel as though those mere 2,500 votes was an Indian voting bloc. Because neither side folded, it is unclear if Neuberger "fell" for the bluff. There were many organized Indian rights organizations, but they did not centrally control the voting patterns of Natives as James had alluded. Regardless, the bluff gave Charley a mainline to an up and coming senator.

\footnotetext{
128 Charley to James Nov 10, 1954, folder 42, box 1, JJP.

129 James to Charley, Nov 10, 1954, folder 59, box 1, JJP.
} 
Click Relander, a Yakima City newspaper editor and Indian rights ally, questioned James and Charley's strategy. "I don't believe in going around waving blocks of voters or such at candidates or others to intimidate them... There would be no need of that with sincere men and sincere Indians," Relander scolded James. "I know how hard you worked on this," Relander continued as he offered to work with the Yakima County Auditor to get special registration clerks on the Yakama reservation. Relander cautioned against any alliance with a political party. Indeed, threats to treaty rights came from both Democratic and Republican administrations. ${ }^{130}$

However, Charley and James had already been working both sides of the political aisle. In the final days of the 1954 elections, James had sent out several dozen form letters to senators up for election. Each letter opened with, "will you please give us a statement on your views-intentions should you be elected?" These letters were a litmus test. Specifically, the letters asked each candidate or incumbent for "your reactions to public law 280, as well as other laws breaking up the security of Indian people." Furthermore, each letter asked, "what will you do...to rectify the injustices that has and is being done to the Indian People, and restore to them their fishing rights that is being taken by building dams?" Neuberger responded directly to the letter while Cordon, like most senators, appears to have ignored the letter altogether. For the most part, those replying in support of Indian fishing and opposed to Termination tended to be the

130 Click Relander to James, Nov. 6, 1954, folder 31, box 1, JJP. 
opposition Democrats, with only a few empathic Republican respondents. Democrats tended to be more willing to stand up for Indian rights in the 1954 election cycle. ${ }^{131}$

James and Charley's political bluff and Relander's voting registration campaign represented two separate issues: Stopping The Dalles Dam and establishing Native voting infrastructure. Stopping The Dalles Dam required quick action-like playing politics and using the rhetoric of voting. Yet, Charley was too busy to engage in the substantive work of voting rights. All three men agreed that Indians could have better representation if Indians could vote, but the bureaucratic loopholes and the generations of Yakamas who were skeptical of any new government policy could take years to overcome and address. Voting was important, but it would take time. "From now on we are going to be on the look out...we are making more friends in the capitol, although we don't vote for them but we can campaign for them," Charley expressed to James. ${ }^{132}$ While Charley had not campaigned for Neuberger, he used the Hells Canyon giveaway, his disdain for Cordon, and the idea of a unified Indian vote as a way to gauge Neuberger's and other candidate's intentions.

\section{Conservation, Douglas McKay, and Wayne Morse}

Charley was not bound to the Democratic Party. In fact, he was willing to play the

\footnotetext{
131 This is a rough generalization, and for the purposes of this thesis, I have decided to forgo a quantitative analysis of all representatives and senators contacted and their subsequent replies. For an example of a form letter and Charley's prompt see, James to Donald H. Magnuson, Oct. 12, 1954, folder 50, box 1, JJP; Charley to James, March 3, 1954, folder 42, box 1, JJP.

132 Charley to James, March 3, 1955, folder 42, box 1, JJP.
} 
politicians against each other. After Neuberger's election to the U.S. Senate, Charley and James set their sights on the next round of congressional elections. The reelection of Oregon's Senator Wayne Morse, himself a political rogue and opponent of Eisenhower, was a prime example of Charley and James's continued political maneuvering. Charley did not support Morse initially, but he pivoted to support him once the Republican Party selected Douglas McKay, who was an even bigger threat to Indian rights.

In 1953, Morse had worked to get Wilson Charley and fellow Yakama Watson Totus before the Senate Appropriations Committee to express their arguments against The Dalles Dam. ${ }^{133}$ Morse's independent politicking was best evidenced during the 1952 presidential campaign. Morse had broken off from the Republican Party over Eisenhower's selection of Richard Nixon as his Vice President. Morse loathed Nixon's anti-communist rhetoric and the administration's stance on promoting public/private partnerships. Morse was actively looking for ways to embarrass the Eisenhower administration. ${ }^{134}$ Yet, it is still unclear whether Morse's gesture to Charley centered on a sudden sympathy for the Yakama or if it was just a political power play to harm Eisenhower.

Morse supported building The Dalles Dam, although, he was willing to grant Columbia River Indians hearings so they could testify and set their opposition in the

\footnotetext{
133 Senator Wayne Morse to James, Feb 3, 1953, folder 21, box 1, JJP.

134 Drukman, Wayne Morse.
} 
Congressional Record. For this, Charley respected Morse, even though they did not see eye to eye on The Dalles Dam. "Morse...has power and he knows where to go just like when I first went back [to D.C.], he was the one that got us the hearing." Reflecting back, Charley explained to James, "Morse was for the dam." With Morse up for reelection in 1956 and running as a Democrat, there might be an opportunity for the Yakama to campaign, or orchestrate a bluff, for a Republican candidate that could oust Morse and better protect the rights of Columbia River Indians.

In May of 1955, Charley asked James to write Senator Barry Goldwater, the chairman of the GOP senatorial campaign committee, requesting the GOP field a candidate to unseat Senator Wayne Morse. "This is not a herculean task if the Republicans will change some of their legislation and live up to the treaty [of 1855]" wrote Charley. He requested moving The Dalles Dam up river to prevent inundating Celilo and "Save the cemetery of the Indians where their noble dead rest..." $\mathrm{He}$ continued,

Can we as Americans stand idly by and see such destruction and not protest?... If the Republican Party will put its house in order and launch a campaign for the protection of Indian rights then they can and will be kept in office, but it the Republican Party will not then the Democratic Party will and they will take over the government of the United States and Restore the rights of American Indians.

In conclusion, Charley's letter noted, "Hoping the Republican Party will see the 
error of their way and make amendments for past wrongs."135

Charley not only gave the Republican Party an invitation to oust Morse, but a playbook to do it. He exposed the unequal footing of Indian rights to private property rights and gave the GOP easy talking points to appeal to Indians and Indian rights supporters. The specifics of his request are also noteworthy. The importance of the treaty: hunting, fishing, gathering rights, and the right to protect his ancestors all were and would continue to be the most important aspects of Charley's work. Charley could juxtapose tribal concerns next to non-native users. The GOP received thousands of letters suggesting political strategy, and so it is not surprising that Charley and James' letter did little to sway GOP strategy.

Oregon's 1956 senatorial election took an interesting turn when the GOP selected Douglas McKay to run against incumbent Senator Wayne Morse. Given Charley's negative perception of McKay_largely because of the public/private partnerships and supporting termination - Morse must have been analogous to that age old saying, "the enemy of my enemy is my own friend." In other words, Charley quickly reversed course and backed Morse to defeat McKay. ${ }^{136}$

Supporting Morse in 1956, Charley joined a large coalition of conservationists

\footnotetext{
135 Charley to James, May 15, 1955, folder 42, box 1, JJP. For the Goldwater's prediction see, “Goldwater Sees Defeat for Morse, 3 Mates" The Oregonian, May 15, 1955, p. 1.

136 Franklyn D. Mahar, "The Politics of Power: The Oregon Test for Partnership," The Pacific Northwest Quarterly 65, no. 1 (1974): 29-37.
} 
against "give away" McKay. The junior senator, Richard Neuberger, had also quickly built a name for himself by opposing McKay's interior policies — especially those regarding Hells Canyon and the Echo Park Dam in Dinosaur National Monument. Neuberger's impassioned political speeches on the floor of the Senate had pitted him in direct opposition to McKay. ${ }^{137}$ Relaying Neuberger and Morse's fight to defeat McKay to the Yakama Tribal Council, Charley noted, "we are not the only ones having troubles [with McKay], the government is having troubles also." Charley suggested that McKay's policies might be hurting the Eisenhower administration. Reading conservation literature in magazines and the press that supported public land protections and public resources, Charley noted to James, "People are getting wise and getting fed up with him [McKay]." McKay's threats to public lands pushed many to support Morse instead. ${ }^{138}$

The goal of reelecting Morse dovetailed with Charley's conservationist allies like Gertrude Jensen of the Save the Gorge Committee. Charley was eager to attend a Morse campaign luncheon hosted by Richard Neuberger in The Dalles. The luncheon would also be a good time to ascertain "how far can we go to get Morse back on the senate, we'll need the Jensens' support for him also," Charley noted to James. ${ }^{139}$ The above passage reveals two important points in Charley's involvement in Morse's election. First,

\footnotetext{
137 Neuberger, "Wayne L. Morse: 1956 and Beyond" in Neuberger, They Never Go Back to Pocatello, 141 - 43; Drukman, Wayne Morse. 257 - 68, 285.

138 Charley to James, April 13 1956, folder 42, box 1, JJP.

139 Charley to James, April 1, 1956, folder 42, box 1, JJP.
} 
Charley realized that for Morse, the support of the Yakama reservation in Washington meant little electorally. However, getting Oregon voters, like James and the Jensens, to communicate the concerns of the Yakama could bring results in policy and at the polls.

The politics of conservation were a key strategy for Morse to defeat McKay. Morse attacked McKay for being soft on public lands, with offshore oil, Dinosaur National Monument, and Hells Canyon being the main pieces of evidence. In particular, James and Charley suggested Morse and Neuberger attack McKay's statements on flood control protection to the Columbia River. Charley understood that The Dalles Dam and the Idaho Power Company dams would not afford flood protection as McKay had promised. Charley believed that McKay was hiding the larger corporate benefits and using flood control as a convenient argument to push his dam agenda. Charley was correct, the Columbia River dams including The Dalles are run-of-the-river dams and afford almost no flood control storage. Likely McKay was using the devastating Vanport flood of 1948 as an emotional trigger to get people to blindly support dam building writ large. Indeed, there were many flood control projects underway in the Columbia Basin, and Charley even supported a few of these specific projects, but to suggest that The Dalles Dam would add flood control was completely inaccurate. Upset over this misinformation Charley and James let Neuberger know, "to use flood control as it has been stated so many times comes under false statements, so opposition can be smoothed over when a dam is to wipe out scenery or other resources." An article in Field and 
Stream shared this suspicion and further suggested McKay would not favor sportsmen's conservation policies. Forwarding the article to Neuberger, James wrote, "I believe there is something there that he [McKay] should face...even with the money he has backing him, I cannot see how he can make it." Conservation, particularly favoring private firms on public lands proved to be a major component of the election, and James predicted Morse would defeat McKay. ${ }^{140}$

The prediction became a reality. On Wednesday, November 7, 1956, Morse's narrow lead became a commanding majority. The Oregonian attributed Morse's victory over McKay to a "repudiation of the administration's power and conservation policies." 141 Indeed, conservation had played an enormous part in the 1956 Oregon senatorial election and part of that rhetorical drive was the behind the scenes work of Wilson Charley and James James. However, Morse still supported The Dalles Dam. Thus, Charley celebrated the defeat of McKay but not Morse's victory.

Charley's skepticism of Morse was understandable. In the run-up to the 1956 election James frequently wrote to Morse and requested he meet with Charley. The common reply was an invitation to Morse's next luncheon or speaking engagement, a typical gesture for any interested supporter. However, Morse did not realize that Charley and many Indians, some of whom were interested Oregon constituents, were often busy

\footnotetext{
140 James to Neuberger, June 1, 1956, folder 63, box 1, JJP; Harold Titus, "Conservation Column” Field and Stream, June 1956, p. 40.

141 “Morse asks for Unity; McKay Thankful for Votes," The Oregonian, November 8, 1956, p. 16.
} 
fishing, trying to haul in as much fish for income and barter as they could during the peak run. With the threat of the dam coming closer to reality, fishing became an increasing priority for Charley. These runs and the open and closed times to fish could not necessarily be scheduled or planned out months in advance like the Senator's schedule. Charley required a flexible schedule to fish and most senators were rigid in their appointments and insensitive to Native Fishermen's nuanced schedules. Relaying frustration Charley noted, "I sure wanted to be at The Dalles tonight for Senator Morse will Speak there...our salmon fishing has made us missed all the senators. This fall they have been in Yakima when we [were] busy fishing and some of the tribal members were not there either." 142 Neuberger had given Charley an open invitation to meet when it was convenient, but Morse's schedule did not accommodate Charley.

Charley's involvement in the election of Morse and Neuberger shows his own complex understanding of the American political process and how he engaged in the intellectual threads of conservation and proto-environmentalism. To many Native fishermen, conservation had long been a pejorative. Moreover, Charley realized that Native fishermen could redefine the term and use it as a way to gain support from both politicians and the general public. Having the sympathetic ear of a politician provided an enormous advantage in fighting the dam, but it also had obvious limitations. Reflecting on his support to oust Cordon and elect Neuberger, Charley affirmed that his actions

142 Charley to James, October 1, 1956, folder 42 Box 1, JJP. 
benefitted all residents of the Columbia River. Charley wrote, "I planted a seed to what Mr. Cordon was doing by hurting not only the Indians but his neighbors also."143 In an effort to appear relevant to the larger society, Charley framed his concerns about The Dalles Dam beyond his own treaty rights to that of the whole society using the language of conservation.

\section{Pressure Through Public Opinion and Media}

Working upstream against the press, which characterized Indian opposition to The Dalles Dam as futile, Charley recognized that publicizing the dam's aesthetic and scenic impacts to the gorge might garner support from proto-environmentalists. However, he had to reverse public opinion on Celilo. Press coverage of Hells Canyon touted taglines like 'Let's not build any dams in Hells Canyon. Let's not do anything to spoil the biggest piece of unspoiled grandeur in the U.S. Northwest." Sometimes, articles defending Hells Canyon's nature from dams ran on the same pages and issues of papers covering the Yakama's fight to save Celilo Falls. ${ }^{144}$ While it might be tempting to see this as a reporting bias, it had more to do with how conservationists distinguished what was worth saving. Preserving Hells Canyon, a seemingly "wild" scenic space, fit with the conservation agenda. Saving Celilo Falls, an active, adaptive, space of Indigenous commerce and culture did not fit the "wild nature" that preservationists sought.

\footnotetext{
143 Charley to James, March 3, 1955, folder 42, Box 1, JJP.

144 See, for example, Oregonian, April 7, 1955, front page.
} 
Appealing to a wider conservation movement, Charley and James framed their fight for Celilo in concert with the Echo Park Dam in Dinosaur National Monument. There, a range of conservation organizations, most notably the Sierra Club, National Parks Association, and the Wilderness Society, had quickly denounced the Bureau of Reclamation's (BoR) plan to flood Dinosaur National Monument. Using their newsletters, magazines, and syndicated writers, conservation groups brought "this hardly known part of the national park system into public view." By advertising the rugged, pristine, and peopleless aspects of this remote part of the Colorado River, conservation groups struck a chord with recreationists and nature lovers alike. Through a compromise with the Sierra Club, the BoR abandoned Echo Park. ${ }^{145}$

Charley and James wanted to mirror the tactics of Echo Park conservationists. In early 1953, James wrote Frank Westwood, editor of Nature Magazine, requesting that he also oppose The Dalles project. "We would be glad to help out in any way we can," replied Westwood as he offered to carry a short note in the June 1953 issue. Westwood recommended reaching out to the National Parks Association, the Wilderness Society and consult with Interior Secretary McKay on National Monument Status. ${ }^{146}$ Indeed, the June issue of Nature Magazine carried a short paragraph noting The Dalles Dam as a violation of the 1855 treaty and that "the Indians are fighting this and they are not alone.

\footnotetext{
145 Quoted in, Mark W. T. Harvey, A Symbol of Wilderness, 52. 146 Westwood to James, March 23 1953, folder 22, box 1, JJP.
} 
Many Oregonians...have rallied to fight with them."147 However, this was the sole piece opposing The Dalles Dam published by Nature Magazine.

Thanking Westwood, James requested space for a more substantive article on the significance and meaning of the falls to Indian people with a feature interview with Wilson Charley. Especially, as James noted, because "this information has never been printed, the papers always just mention the fishery."148 Westwood replied noting his backlog of material and that the effectiveness of an article would "depend... on whether the dam can be held off long enough to continue a back-fire against it."149 James still pushed harder for a piece espousing Yakama fishing practices as "ancient conservation bestowed to the Indians by the Great Spirit." Westwood replied feeling an article “probably shouldn't be approached from that conservation philosophy viewpoint.” In a final letter, Westwood clarified that he was still interested in publicizing the Yakama's tragedy as a learning example for the future but that "I can't help but feel this is a lost cause." He reiterated that because the project had just begun, there was no chance for National Monument designation and his organization was too busy with the Echo Park fight to give any greater support. ${ }^{150}$

\footnotetext{
147 Nature Magazine 46, no. 6 (June 1953).

148 James to Westwood, June 18 1953, folder 56, box 1, JJP.

149 Westwood to James, June 22 1953, folder 22, box 1, JJP.

150 Westwood to James, November 21953 folder 22, box 1, JJP; Westwood to James January 28, 1954, folder 22, box 1 , JJP.
} 
Charley and James knew National Monument Status was a crux issue in saving Celilo and had been exploring the idea since 1952 when James first wrote president-elect Eisenhower requesting he consider its designation. ${ }^{151}$ They had contacted Eleanor Roosevelt, John D. Rockefeller, and Gertrude Jensen of the Columbia Gorge Commission, all of which were receptive but ultimately unhelpful. ${ }^{152}$ Skeptical of monument status for Celilo because it might nullify treaty rights, Charley and Tribal Chairman Alex Saluskin recognized that the Yakama themselves could use monument status as a tool. ${ }^{153}$ On several occasions, Charley had tried to personally meet with the President to discuss the issue, but each time the White House refused. ${ }^{154}$

James and Charley continued to push Eisenhower even going so far as to invite his brother, Dr. Milton Eisenhower, to travel as a guest of the tribe to Toppenish. The plan could take Dr. Eisenhower to observe Yakama men fishing the fall run, where Charley could explain the religious significance of the falls, the rock art, and burial sites.

\footnotetext{
151 Katrine Barber notes Yakama Nation fish biologist F.A. Davidson and Gertrude Jensen proposed monument status to Congress in February 1953. However, James had proposed a monument even earlier. Barber, Death of Celilo Falls, 87 - 8; James to Marion T. Weatherford, Nov. 13, 1951, folder 55, box 1, JJP; James to General Dwight D. Eisenhower, Nov. 1, 1952, folder 55, box 1, JJP.

152 Charley to James, March 22, 1953, folder 42, box 1, JJP; James to John D. Rockefeller, Dec. 5, 1952, folder 55, box 1, JJP; James to Gertrude Jensen, Dec. 30, 1952, folder 55, box 1, JJP; James to Eleanor Roosevelt, Jan 3, 1952, folder 51, box 1, JJP; Eleanor Roosevelt, "My Day" 31, Dec. 1952, accessed online January 5, 2017 at: http:/www.gwu.edu/ erpapers/myday/displaydoc.cfm?_y=1952\&_f=md002419

153 James to Yakama Indian Nation, Dec. 7, 1952, folder 55, box 1, JJP; Alex Saluskin to James, Dec. 30, 1952, folder 46, box 1, JJP.

154 Charles F. Willis, Jr., President's special assistant to Charley, July 13, 1953, folder 42, box 1 JJP; Charley to James, July 30, 1954, folder 42, box 1, JJP; James to President Eisenhower, May 9, 1953, folder 56, box 1, JJP; James to President Eisenhower, Aug 14, 1953, folder 56, box 1, JJP; James to Glenn L. Emmons, Oct 101953 folder 56, box 1, JJP.
} 
Anticipating the visitation, James suggested Charley get his talking points in order: propose a national Indian museum at Celilo, an amphitheater for cultural events "rivaling the Pendleton Roundup," and mention the important tourism components of the site "so it will not appear that you are only interested in fishing." Lastly, they made sure to draw parallels to other dams threatening national parks. ${ }^{155}$ Charley gave James the "green light" to contact the President hoping that perhaps the message might be better received from someone outside the tribe: "if we cannot get to the president...you should find out if you know someone who will be right up to him so he would be able to get our letter personally," Charley wrote to James. ${ }^{156}$ Neither of the Eisenhower brothers replied.

James and Charley were quick to tie McKay's stance on rapid hydropower development as the common denominator between Echo Park, Hells Canyon, and Celilo. James, freshly rejected by Nature Magazine, fired off a letter to C. Edward Graves of the National Parks Association offering his help and requesting assistance with Celilo. ${ }^{157} \mathrm{~A}$ few days later Graves replied and forwarded a message to Edwin R. Murrow at Columbia Broadcasting Station. Graves suggested Murrow investigate McKay and Eisenhower, interviewing politicians at the falls. "It strikes me that this is a natural for your television program. If you could interview the representatives on the spot [at Celilo] you would

\footnotetext{
155 James to President Eisenhower, August 131953 folder 56, box 1, JJP; James to Charley, August 25 , 1953 folder 56, box 1, JJP; James to Charley Oct. 2, 1953 folder 56, box 1, JJP.

156 Charley to James, July 31, 1954, folder 42, box 1, JJP.

157 James to C. Edward Graves, January 5, 1954, folder 57, box 1, JJP; James to A.L. Miller, Chairman, Committee on Interior and Insular Affairs, Jan. 13, 1954, folder 35 box 1, JJP.
} 
have one of the most dramatic locations in the world," he wrote to the CBS journalist. According to Graves, McKay's political stances on hydropower development, Termination Policy, and his proximity to the president raised questions because, he noted, "if Celilo Falls should be proclaimed a National Monument by the President, it would come under Secretary McKay's department."158 Graves proved a perceptive ally in denouncing dams in the west— using Echo Park as his symbol— but his Oregonian editorials all failed to mention Celilo. ${ }^{159}$

Bernard DeVoto, the prize-winning author and hard-nosed conservationist, had been covering postwar land-use issues for Harpers. Graves knew that DeVoto was working on his now famous essay entitled "Conservation: Down and On the Way Out," a scathing critique of McKay's policies in the Interior Department—especially dam building. DeVoto "might like to say something about Celilo Falls," he informed James. ${ }^{160}$ Requesting to join forces with DeVoto in protecting the nation's scenic wonders - Echo Park and Celilo—-threatened by “McKay's utility complex," James reminded DeVoto, "it has been proven that the government can cancel contracts and bring about the wishes of the people, providing it is a just cause.... Will you please

\footnotetext{
158 Graves to James, Jan. 17, 1954 folder 57, box 1 JJP; Graves to Edwin R. Murrow, Jan. 11, 1954, folder 57, box 1 JJP; James to Charley Jan. 14, 1954 folder 57, box 1, JJP; Charley to James Feb. 22, 1954, folder 42, box 1, JJP.

159 C. Edward Graves, "Dams Unnecessary" Oregonian, March 18, 1954 p.12; Graves, "Tram Opposed" Oregonian, Aug. 15, 1954 p. 12; Graves, "Mazama Lecture" Oregonian, April 10, 1956 p. 8.

160 Graves to James, Jan. 11, 1954 folder 57, box 1, JJP; James to Graves, January 18, 1954 folder 57, box $1 \mathrm{JJP}$.
} 
mention the loss of Celilo Falls?"161 Eight months later, DeVoto cited Hells Canyon and Echo Park projects as evidence of Secretary McKay's Interior Department politics. ${ }^{162}$ Western Paradox, his final book published posthumously, contains only minor callouts to development on the Columbia River, fully ignoring the Celilo controversy. It could be because as a conservationist, DeVoto supported a well-regulated federal power program, especially in the Columbia basin. "The Columbia basin lends itself to integrated development; God was in an engineering phase when he created it," DeVoto once wrote. Regardless of the reason, he did not connect Celilo Falls to his advocacy for Echo Park. 163

In their final effort, James contacted Walt Disney requesting a short film reel, and like others, the media requests went unanswered. Charley however, pulled a connection with central Washington journalist Ted Van Arsdol, who finally interviewed Charley for the piece in Man's Life discussed at the beginning of this chapter. Despite a robust and coordinated effort, Charley's interview in Man's Life marks his only featured publication that has come to light. While this piece succeeded in getting his voice out to a general audience, it also affords a counterpoint to the numerous occasions when Charley and

\footnotetext{
161 James to Bernard DeVoto, Jan. 18, 1954, folder 57, box 1, JJP; James to Senator Wayne Morse, Jan. 25, 1953 folder 56, box 1, JJP.

162 Bernard DeVoto, "Conservation: Down and On the Way Out," republished in, Bernard DeVoto, Patricia Nelson Limerick, and Douglas Brinkley eds., The Western Paradox: A Conservation Reader, (New Haven, Conn.: Yale University Press, 2001) 153 - 172.

163 Bernard DeVoto to Raymond Moley, February 8, 1955, in Bernard DeVoto and Wallace Stegner, The Letters of Bernard DeVoto, (New York: Doubleday, 1975) 375 - 6.
} 
James requested help from individuals and institutions only to receive limited support or complete dismissal. The lackluster support for Charley and the concerns of other Columbia River Indians in opposing The Dalles Dam should not be attributed to nonIndians ignorance of Indian concerns; there was plenty of press coverage about the dam and plenty of letters asking the press to cover Native perspectives. For this reason "We destroy an Indian Shrine" has a layered meaning today not understood at that time. Nonnative conservationists who championed saving other sites from dams let Natives like Charley down and had their own role in the destruction of Celilo.

Indeed, the scenic, "wild," seemingly peopleless space at Echo Park became what Historians Mark Harvey and Roderick Nash call "a milestone in the American wilderness movement." 164 Yet, on a deeper level, the drive to protect the millennial record of people in scenic nature did not mesh with the ideals of wilderness parks. Put simply, the protection of Indigenous spaces fell largely outside the scope of wilderness advocates. ${ }^{165}$ Howard Zahniser, the author of the Wilderness Act of 1964, incorporated the term "untrammeled by man" as the core idea of wilderness legislation in 1956. Zahniser

\footnotetext{
164 Nash, Wilderness and the American Mind; Harvey, A Symbol of Wilderness. I take my view of the peopleless wilderness from William Cronon, "The Trouble with Wilderness; or, Getting Back to the Wrong Nature" in, Uncommon Ground: Rethinking the Human Place in Nature, William Cronon ed. (New York: W. W. Norton, 1996).

165 In 1915, President Woodrow Wilson had used the powers of the 1906 Antiquities Act to designate Dinosaur National Monument. The act's powers allowed to president to designate National Monuments and protect archaeological sites from looting by private collectors. Since 1915, the federal government had legally protected thousands of Indigenous sites at Echo Park. With the descendent communities removed to reservations away from the area, the drive to establish the area as a wilderness conveniently ignored the rich precontact archaeological record of people in the park.
} 
defined wilderness as "a place where the earth and its community of life are untrammeled by man, where man himself is a visitor who does not remain." Charley, cued into the ongoing discussions in the Wilderness Society, tried framing his fight to save Celilo in wilderness language. Charley had tried at Celilo "to make sure that some parts of America may always remain unspoiled and beautiful in their own natural way, untrammeled by man and unmarred by machinery." Further commenting on an early version of a wilderness bill he stated, wilderness "is a measure that gives expression to a policy which has long been a realty in the minds and hearts of and minds of the American people but has never been embodied in legislation.” 166

However, conservationists and preservationists dismissed Celilo as a worthy candidate for scenic or wilderness protections. At Celilo, American Indian families were actively practicing their culture of commerce. It was not a peopleless space where Natives were visitors who did not remain —it was, in fact, a nexus of human interaction with nature for thousands of years. Further, Native families at Celilo were not primitive or static "glass case Indians" as so many non-natives expected, but rather, represented a dynamic, changing, and evolving culture in a singular place.

\footnotetext{
166 Charley to James, July 16, 1958, folder 42, box 1, JJP; Outdoor Recreation Resources Commission: Hearing Before the Committee on Interior and Insular Affairs, United States Senate, Eighty-Fifth Congress, First Session, on S. 846, a Bill for the Establishment of a National Outdoor Recreation Resources Review Commission. May 15, 1957 (U.S. Government Printing Office, 1957); Mark W. T. Harvey, Wilderness Forever: Howard Zahniser and the Path to the Wilderness Act (Seattle: University of Washington Press, 2009), 202-6.
} 
Charley saw his culture as having a central stewardship role in protecting Celilobe it a National Monument, wilderness, or reserve. Charley, "with a sincere heart and honesty," had equipped powerful leaders with compelling arguments - morally, legally, and economically — not to build the dam. He pushed some of the great intellectuals of American environmentalism to see nature as a dynamic, changing, and even, a human constructed space. The man-made scaffolds, rock art, and ancestral burials overlooking Celilo Falls complemented the non-human nature and defined Charley's culture, history, and sense of place. The architects of American environmentalism and the politicians that came to champion conservation and preservation missed Charley's more nuanced view of nature and untrammeled lands. The next chapter will further explore how Charley worked to protect the archaeological sites that the dam promised to flood. Although society was set on altering the course of the Columbia River in the 1950s, most importantly, Charley continued to try a variety of strategies to alter the course of that trajectory. 


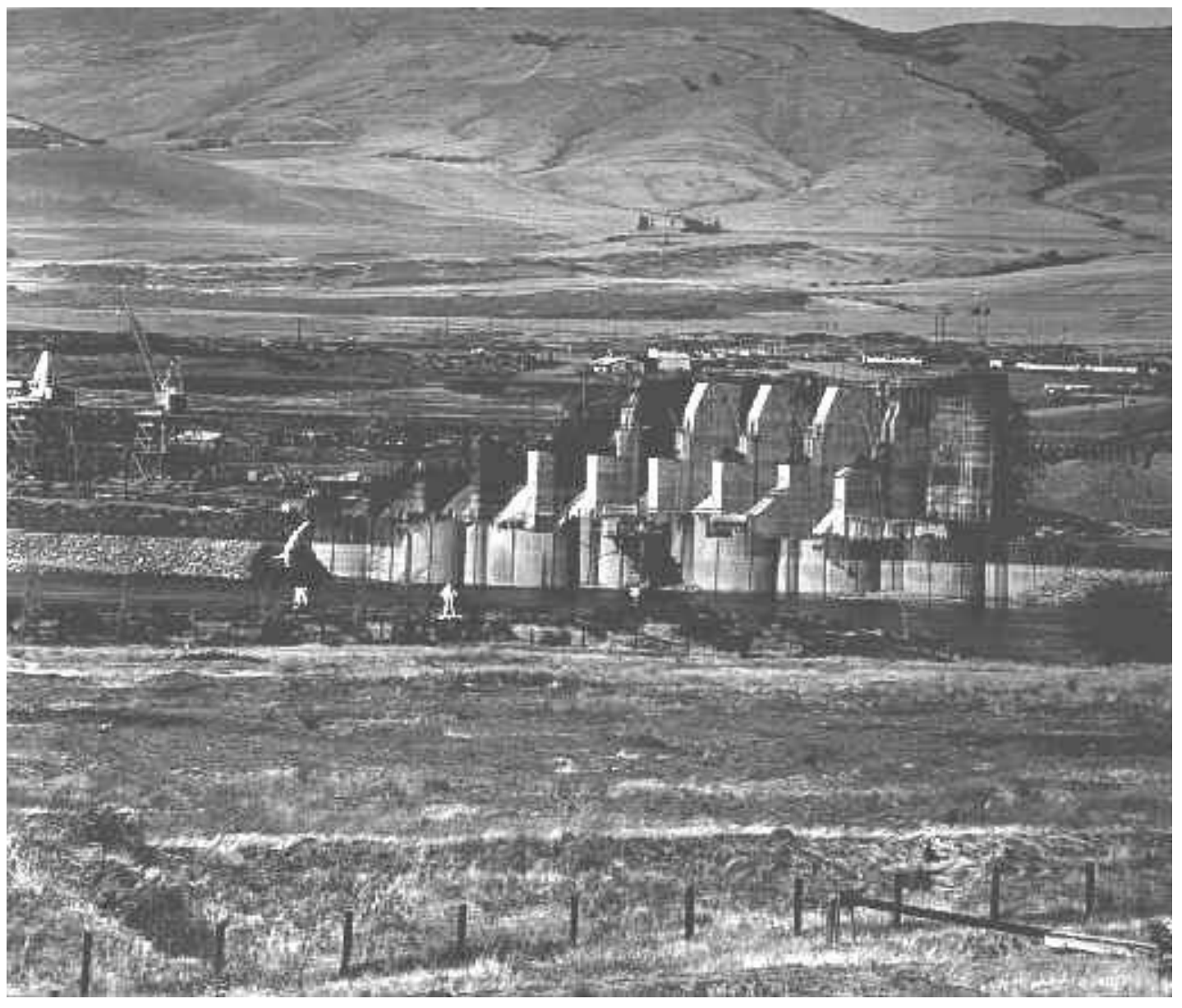

Figure 9: Photographer Ben Maxwell photographed the construction of The Dalles Dam in September of 1954. Compared to figure 8, the construction had progressed rapidly over the summer. Image from the Ben Maxwell Collection, Salem Public Library, Salem, Oregon. 


\section{Chapter 3}

"It is Important for the Public to Know what is Being Done Along the Mighty Columbia River": Archaeology and Protecting Ancestral Landscapes

"I will visit the archaeologists and make my acquaintance so that in the future we may be able to call on them for help in some shape or form."

—Wilson Charley to James James, Aug. 31, 1954

"What we do for our rights, privileges, freedoms, and security forever in perpetuity is for our ancestors, for us, and for our descendants."

—Wilson Charley to James James, March 22, 1955

Wilson Charley never wanted to see The Dalles Dam, but his fishing station at Lone Pine stood front and center to the dam's construction. From his fishing cabin, he looked past the construction upriver to the mouth of the Long Narrows. The variations in the channel and flow of the river, rock outcrops, and the distant hills all marked significant cultural landmarks grounded in oral tradition. These seemingly natural features were imbued with profound cultural meanings — important places that helped tell stories, like when Coyote disguised himself as a baby on a cradleboard and brought the salmon back to the people. Looking to the islands and banks of the river, Charley saw the past, present, and future. His ancestors, who had been the dedicated keepers of this knowledge, were buried in the hills and on the river's islands. Charley's identity, family history, his sense of place, and his livelihood were all a part of what he saw as he gazed 
up river from Lone Pine. For Charley, the significance of these places went much deeper than stunning scenery. ${ }^{167}$

Starting in 1953, Charley began witnessing construction crews using dynamite and heavy equipment as they built the initial pylons for the dam. From his fishing cabin, he witnessed the violent destruction of the ancestral landscape. He worried about the buried remains of his ancestors and how he and younger generations of Columbia River Indians would cope with the desecration. Charley remained steadfast that the Yakama could stop the construction, protect their ancestral sites, and celebrate their own history. Although not fully enumerated, Charley believed burial protections were implied in the reserved rights of 1855 treaty.

This chapter focuses on Charley's work with local archaeological clubs and professionals. Partnerships with these groups, he hoped, would give his concerns increased publicity and political action. If the archaeological community joined the Yakama in stopping the dam, he hoped the tribe could then lead the protection of sacred places and ancestral sites for future generations. Asserting his authority as a direct descendent of individuals buried in specific sites, and as a member of the Yakama Nation Tribal Council, Charley hoped archaeologists would help him stop The Dalles Dam

\footnotetext{
167 The specifics of these cultural landscape features are rightfully deemed "sacred and sensitive" information by the Yakama Nation Cultural Resources Protection Program. Respecting the sensitivity of this perspective, which I learned from a conversation with Yakama Nation CRPP manager Johnson Meninick, I intentionally do not name specific locations, features, and stories. For a good example of the storied aspects of the river see, Eugene S. Hunn, "Sk'in: The Other Side of the River" Oregon Historical Quarterly, 108 no. 4 (Winter 2007) 614-623.
} 
project. However, certain archaeologists commoditized Charley's claim to ancestral sites, especially his detailed family knowledge, and used it to justify their own desires for excavation. Many of these amateur and professional archaeologists took advantage of the opportunity dam building afforded to bolster their private collections and professional careers. Although allied over the intrinsic value of archaeology and cultural sites, nonnative archaeologists' lackluster support in resisting the dam surprised Charley. The groups that rose up and worked to salvage as much material as they could before the dam flooded these sites were more interested in the objects than the landscape and the descendants of people who possessed a complex and detailed understanding of these artifacts and their relationship to place.

Tracing Charley's relationship to these salvage archaeology projects exposes a new dimension to The Dalles Dam controversy that finally places an Indigenous actor at the center of this controversy. Charley was deeply concerned about protecting his ancestral rights and his history. Archaeologists, on the other hand, were more interested in the removal of cultural material for study. Historian Kathleen Fine Dare and others note the long and tenuous relationship between archaeologists, ethnologists, and Native American communities. Few scholars show Indigenous leaders as central actors in advocating for burial protections during the height of the termination era. A decade before the National Historic Preservation Act (1966) and decades before the Native American Graves and Repatriation Act (1990), Charley argued for tribal consultation 
before archaeologists excavated ancestral sites. Further, his work exposes some of the underlying tensions between Native tribes and the archaeological community - tensions still felt to this day. Both Charley and the archaeologists he contacted understood that The Dalles Dam would inundate and destroy the material record of thousands of years of human history, but discordant views on how to protect these sites prevented collaboration. In turn, archaeologists ironically commoditized, captured, and used Charley's claim to ancestral sites, especially the detailed family knowledge, to justify excavation. 168

\section{Ancestral sites as History}

For Charley, like most river Indians, the Columbia Plateau landscape was itself a family history archive. The land was not only the source of food and livelihood, but it was also an anchor for one's culture, family history, and identity. Multilingual families shared their history through oral traditions, physical properties, place names, and objects. Plateau women had long recorded history and cultural traditions. Objects like a basket, root digging stick, or a hemp counting-ball, are a detailed record of change over time still

\footnotetext{
168 Kathleen S. Fine-Dare, Grave Injustice: The American Indian Repatriation Movement and NAGPRA (Lincoln: University of Nebraska Press, 2002); Wendi A. Lindquist, "Stealing from the Dead: Scientists, Settlers, and Indian Burial Sites in Early-Nineteenth-Century Oregon," Oregon Historical Quarterly 115 , no. 3 (2014): 324-43; Gretchen M. Bataille, David Mayer Gradwohl, and Charles L. P. Silet, eds., The Worlds between Two Rivers: Perspectives on American Indians in Iowa, (Iowa City: University Of Iowa Press, 2000); David M. Gradwohl et al., "Still Running: A Tribute to Maria Pearson, Yankton Sioux," 2005.
} 
used by descendent peoples to tell their history. ${ }^{169}$ In a similar vein, the pictographs and petroglyphs along the Columbia River are not simplistically art. As Columbia River writer William D. Layman notes, art is a western imposed term. Rather, he argues that these pictographs and petroglyphs are historical records of Plateau people, "a written history that tells the story of their people."170

Although objects tell plateau people's history, so does the landscape. Place names archive history and cultural meaning, turning space into place. ${ }^{171}$ Many ethnographers and historians have tied the production of place to an understanding of one's own culture and history. In his study of place-naming among the Western Apache, Keith Basso notes, “[k]nowledge of places is closely linked to knowledge of the self, to grasping one's position in the larger scheme of things, including one's own community, and to securing a confident sense of who one is a person."172 As these scholars show, Indigenous place naming bestows meaning and tells the history of a people. The Columbia River Plateau is no exception. For example, $S k$ 'in (cradleboard) is an important village site near present

\footnotetext{
169 Pat Courtney Gold, “The Long Narrows: The Forgotten Geographic and Cultural Wonder” Oregon Historical Quarterly, 108 no. 4 (Winter 2007) 596-605.

170 Mary Dodds Schlick, Columbia River Basketry: Gift of the Ancestors, Gift of the Earth (University of Washington Press, 1994); Leibhardt Wester, Land Divided by Law; Ackerman, A Necessary Balance; William Layman, "Riverplaces as Sacred Geography: The Pictographs and Petroglyphs of the MidColumbia River," in Great River of the West: Essays on the Columbia River, ed. William Lang and Robert Carriker (University of Washington Press, 2000): 56.

171 Yi-Fu Tuan, Space and Place: The Perspective of Experience (Minneapolis: University of Minnesota Press, 1977).

172 Keith H. Basso, Wisdom Sits in Places: Landscape and Language Among the Western Apache (Albuquerque: University of New Mexico Press, 1996); Carlson, The Power of Place Problem of Time; Thomas F. Thornton, Being and Place among the Tlingit (Seattle: University of Washington Press, 2007); Cruikshank, Life Lived Like a Story.
} 
day Wishram, Washington. Here, a series of narrow deep-cut falls flow to a large eddy and sand bar below. Unlike other fishing spots along The Dalles reach, which featured wooden scaffolds and platforms for dip netting, $S k$ 'in was a prime seine net fishery and noteworthy place to harvest Pacific Lamprey (lampetra tridentata.) ${ }^{173}$ A central place for Sahaptin-speaking plateau peoples to disseminate craft of seine net construction $S k$ 'in also tells the story of how Coyote broke the dam that brought the salmon back to the people. ${ }^{174}$

\section{Approaching the Oregon Archaeological Society}

Charley looked to the archaeological community as an obvious ally in opposing The Dalles Dam. Both he and archaeologists valued the gorge's ancestral sites and did not want to see them flooded. Founded in 1951 by a group of avid "pothunters with a purpose," the Oregon Archaeological Society was primarily "interested in archaeology and Indian lore.” The society's beginnings typify non-natives' anachronistic curiosity of Indigenous people in the 1950s — particularly because of their fascination with Indian artifacts. The work OAS conducted in the Columbia Gorge legitimized non-academic archaeology, site mitigation, and helped establish a variety of archaeology as a subcomponent of construction development. Article one of the OAS constitution states the group's mission was "to preserve in the Northwest for the benefit of science and the

\footnotetext{
173 Hunn, Nch ’i-Wána, 153-156.

174 Eugene S. Hunn, "Sk'in," 614-623.
} 
public the local archaeological and historical material and traditions that are it's [sic] heritage." Subsequent sections enumerated the group's collaboration with professional archaeologists, public agencies, and landowners, as well as the mission to educate the public. Nowhere in the OAS constitution did it mention Indian tribes or recognize descendant communities as collaborators or keepers of place-based knowledge, and it is fair to note that most similar organizations would not have considered tribal consultation at this time. However, OAS's concern about the sites and artifacts of Charley's ancestors is what caught the attention of Jimmy James. ${ }^{175}$

For Wilson Charley, OAS was indeed a potential ally, and Jimmie James had much to do with the introduction. As early as 1951, Jimmie James learned of the group and began attending meetings. In March of 1952, James officially joined OAS and offered his artistic services to the society. From this time on, all issues of the monthly newsletter Screenings bore James's line drawing and a short anecdotal column entitled “my big mouth.” At his first OAS meeting, James informed vice president Emory Strong of his artistic depiction of Celilo Falls, "untouched by the meddling white man and manner in which the Indians lived," which he was painting using charcoal from Newberry Crater radio-carbon-dated to 7000 years ago. James, a romantic artist, had his

\footnotetext{
175 OAS's leadership was largely Portland based volunteers, with Howard Galbraith, a carpenter and boat builder from the St. John's neighborhood, and Emory Strong, a Portland construction engineer, serving as the president and vice president for alternating terms through the 1950s. See, George R. Poetschat, Harvey Steele, and Oregon Archaeological Society, The Formative Years of the Oregon Archaeological Society: Screenings Newsletters 1951 through January 1955, No. 10 (Portland: Oregon Archaeological Society, 1997). Janet Goetze, "St. Johns Activist Galbraith Dies at 69," The Oregonian, May 7, 1981, p.c1.
} 
own ethnocentric view of Columbia River Indians, which simplistically placed Indians as landscape features in a harmonious and static relationship with nature. ${ }^{176}$

Like James's romantic artwork, the early newsletters of OAS are of a different time. They are full of ethnocentric judgments of Indigenous people, blatant racism, and little concern for the descendants of the ancestral sites. For example, the first meeting of the society included a lecture by Norman G. Seaman, a private collector and author of Indian Relics of the Pacific Northwest. Today, archaeologists would admonish Seaman's work. He completely left contemporary Indians out of the narrative and depicted Native cultures in a primitive stasis. Seaman explicitly condoned looting Indigenous burials for their grave goods and promoted public digging in archaeological sites near The Dalles. Next, Robert H. Miller spoke of his collection of net sinkers which "he had dug out a river bank east of Vancouver." Earl Marshal had a set of color sides of "Indian rock writings and it was quite obvious he knew what he was talking about." Thomas Colt, director of the Portland Art Museum, opened the vault for examination and spoke "about the work the museum was doing with Northwest Indian material.” Additionally, Colt invited OAS to hold future meetings at the museum, providing a veneer of professional approval between to relic collectors and the Portland Art Museum. Moreover, the men who spoke at the first meeting demonstrate that amateur archaeologists not only saw

176 James to Dr. Robert F. Heizer, Professor of Anthropology UC Berkeley, Nov. 25, 1952, folder 55, box 1, JJP; James to Emory Strong, March 12, 1952, folder 55, box 1, JJP. 
these non-native men as authorities in terms of the artifacts they collected but also as experts in interpreting the culture of precontact Indigenous people. No one at OAS considered that the Native leaders like Charley might be experts and have something to say. ${ }^{177}$

James wrote to President Strong offering his artistic help and pleaded for OAS to condemn The Dalles Dam. Reading of James's art and advocacy to save Celilo, Strong replied, "the project you have undertaken is most interesting and I would like a story on it for the bulletin." Regarding OAS condemning the dam, Strong wrote, "we would be jousting at windmills to attempt to stop the Army Engineers on the Columbia."

Nonetheless, Strong continued, "I do feel that we should make our voice heard in protest of the damming of every little river...such as the Deschutes, Rogue, and Santiam." Carrying a short note on James's art, Strong included no condemnation of The Dalles dam in the subsequent issue of Screenings. ${ }^{178}$

Regardless of Strong's feelings about the dam, it is clear that James's membership with OAS, especially his regular column in Screenings, allowed him to subtly question the dam's effect on the riverscape. Soon after joining OAS, James quickly fired off a letter to Yakama Tribal Council Chairman Alex Saluskin inviting him to attend a

177 N. G. Seaman, Indian Relics of the Pacific Northwest (Portland: Binford \& Mort, 1980); Virginia L. Butler, "Relic Hunting, Archaeology, and Loss of Native American Heritage at the Dalles," Oregon Historical Quarterly 108, no. 4 (December 1, 2007): 624-43.

178 Strong to James, March 15, 1952, folder 51, box 1, JJP; Screenings, vol. 1 no. 2, April 1952. 
monthly meeting and offer a tribal perspective. ${ }^{179}$ Unfortunately, for the Yakama, it was “impossible for us to have a representative at the Oregon Archaeological Society meeting on April $14^{\text {th }}$. Your letter was received too late to make the necessary arrangements," replied Saluskin. ${ }^{180}$ Instead, Gertrude Jensen of the Save The Gorge Committee spoke before the society's April meeting. She "devoted a good deal of time to arousing public consciousness of the threat to the scenic grandeurs of the gorge," Screenings proclaimed. ${ }^{181}$ Jensen was such a hit among the group that Strong asked James to present at the next meeting. Obtaining the historic Grant House at Ft. Vancouver for a summer social, Strong asked James to build upon Jensen's presentation. "Members of the Society would very much like to have you for the speaker for the evening, as we feel you have a message for us," Strong wrote to James. ${ }^{182}$ Instead, James led a guided tour of Celilo Falls from the Wishram side of the river, where according to Screenings, "several members have been digging" during the society's summer field season. ${ }^{183}$ It is unclear if James claimed to speak on behalf of the Yakama, but he did at least push OAS to see the correlation between The Dalles Dam and the destruction of Indigenous archaeological sites.

\footnotetext{
179 James to Alex Saluskin, April 8, 1952, folder 55, box 1, JJP.

180 Saluskin to James, April 15, 1952, folder 46, box 1, JJP.

181 Screenings, Vol. 1. No. 3, May 1952.

182 Strong to James, May 4, 1952, folder 51, box 1, JJP.

183 James to Strong, July 28, 1952, folder 55, box 1, JJP; Poetschat, et. al., The Formative Years of the Oregon Archaeological Society, 18 - 20.
} 
James kept pushing the society to fight the dam. Members of OAS grew anxious. One the one hand, the fate of the archaeological sites worried the society, but the thought they might get to participate in some salvage excavations introduced excitement. In February of 1953, President Howard Galbraith read yet another plea from James to condemn the dam. "Your very impressive letter was read to the group.... a motion was made and carried with unanimous approval, to go on record as being opposed to the dam," wrote Galbraith. Member Earl Marshal introduced the motion, which stemmed from the threat to the pictographs and petroglyphs near the construction. Marshal and Galbraith's opposition centered a desire to remove the petroglyphs, not support local Native concerns. ${ }^{184}$

\section{Salvage Archaeology}

Amateur relic collecting and the black market antiquities trade have a wellestablished history along the Columbia River that predates professional archeology. However, by 1940s, university-trained archaeologists could legitimately distinguish themselves from relic collectors. Archaeologists, such as Luther Cressman at the University of Oregon, focused on stratigraphic context, artifact association, and systematic slow excavation. For Cressman and his contemporaries, the goal was not to simply build museum collections but to establish a chronology of precontact cultures. In 1950, Cressman began a systematic research program at the University of Oregon

\footnotetext{
184 Howard Galbraith to James, Feb. 21, 1953, folder 51, box 1, JJP.
} 
investigating the precontact Columbia River. From 1952 - 1956, he received funding to conduct archaeological excavations in the reservoir area behind The Dalles Dam. ${ }^{185}$

The federal government recognized that dams often flooded important archaeological sites. The 1945 federal River Basin Surveys program had appropriated meager funds to salvage archaeological sites damaged by Army Corps of Engineers and Bureau of Reclamation dams. Although seriously underfunded and lacking legal regulations, the program effectively merged dam construction with archaeology. At sites impacted by a dam, the program allowed archaeologists to excavate (itself a destructive task), catalog, and study sites before dam construction began. This established the idea that recovering the archaeological data could mitigate the overall effect of a dam. With essentially the entire riverbank on both sides of the river from The Dalles Dam site to McNary Dam being a continuous series of archaeological sites, the program's meager funds were not enough to fully mitigate the archaeological impact in the Columbia River Basin. To cover the gap in funding university-trained professionals utilized eager volunteer OAS collectors in an ad hoc team as they conducted excavations at The Dalles Dam. ${ }^{186}$

185 L. S. Cressman et al., "Cultural Sequences at the Dalles, Oregon: A Contribution to Pacific Northwest Prehistory," Transactions of the American Philosophical Society, New Series, 50, no. 10 (January 1, 1960): 1-108; Butler, "Relic Hunting, Archaeology, and Loss of Native American Heritage at the Dalles." ${ }^{186}$ According to Virginia L. Butler, "from 1952 to 1956 the RBS spent $\$ 210$ thousand for all archaeological work in the country's reservoirs, except in the Missouri Basin. Those funds were spread across 254 reservoirs in twenty nine states." Ibid, $631-632$. 
In October of 1953, Louis Caywood of the National Park Service authorized OAS volunteers to assist him as he led excavations at the Five Mile Lock site. After recording and cataloging the excavated artifacts, Caywood agreed to hand them over to volunteers to keep in payment for their labor. OAS members were excited to keep the artifacts, and it set a controversial precedent. As Screenings noted, "Our society is the only one aside from colleges and scientific groups that has ever obtained a permit to the National Park Service to do this type of work in Oregon. Let's all support the project and prove we can do the job to everyone's satisfaction." Just six months prior, OAS had resolved to oppose the dam. The opportunity to join in the salvage work muted the group's opposition to the dam. In fact, it was precisely because of the dam that OAS members could now legitimately dig and collect artifacts. ${ }^{187}$

Five Mile Lock was only the tip of the iceberg. Volunteer excavations in the Spedis Valley, particularly at Wakemap, exposed the inability of professional archaeologists to control the volunteers adequately. Wakemap Mound, forty feet thick and three hundred feet in diameter, was itself an extensive archive of human occupation dating back thousands of years. In 1953 and 1954, Warren Caldwell of the University of Washington directed excavations and used volunteer labor-allowing individuals to keep artifacts. The frenzy to collect at this deeply stratified site became too much to handle for

187 Screenings, Vol. 2, no. 7, Oct. 1953 in Poetschat, et. al., The Formative Years of the Oregon Archaeological Society. 
Caldwell and the 1953 - 1954 field seasons became known as the "battle for Wakemap," because so many eager looters picked the site that it resembled craters and pockmarks of a battlefield. Caldwell tried to catalog all the artifacts before they disappeared into individual collections, but the tight timelines left him overextended. Even Caldwell acknowledged that this was not the best method for excavation, especially given the significance of the site. ${ }^{188}$

\section{To sue for damages or negotiate a settlement}

What was happening with OAS was not what Wilson Charley had wanted in a partner. Quickly, Charley read up on the River Basin Surveys program. Obtaining copies of the Smithsonian archaeologist Joel Shiner's past surveys at McNary and Sauvies Island, Charley looked for a legal recourse to stop the volunteer excavations. James sent the reports and noted, "I expect you have been going through quite a bit lately," suggesting that the salvage work was indeed offensive to Charley. Certainly, it was, but not because of the artifacts per se. The frenzy to collect disrespected his ancestors and overshadowed the importance of leaving human remains alone. Artifacts and archaeology were important to Charley, but he viewed those objects as the rightful possessions of his ancestors. ${ }^{189}$

\footnotetext{
${ }^{188}$ Screenings, Vol. 3. No. 2, Feb. 1954 in ibid.; Butler, "Relic Hunting, Archaeology, and Loss of Native American Heritage at the Dalles"; B. Robert. Butler, "The Physical Stratigraphy of Wakemap Mound: A New Interpretation.” (M.A. Thesis, University of Washington, 1960).

189 James to Charley, Nov. 16, 1953, folder 56, box 1, JJP; Smithsonian Institute, River Basin Surveys, "Appraisal of the Archaeological Resources of the McNary Reservoir: Oregon and Washington," Jan.
} 
In and out of the hospital with a bad leg and a bout of bronchitis through the first months of 1954, Charley was unable to take much action regarding the salvage archaeology. His concern centered less on the artifacts and more on the many ancestral burials along the river. Because of vicious outbreaks of disease just a few generations prior, there had been a proliferation of burials along the river that would be damaged if the dam came to fruition. ${ }^{190}$ Charley and many other river Indians still knew the exact names and locations of their ancestor's graves. At the same time, generations of mistrust and betrayal had kept this knowledge closely held and highly guarded. Furthermore, events at "Battle of Wakemap" and Five Mile Lock confirmed Charley's and other river Indians' suspicion that archaeologists did not prioritize local Indians concerns.

When Charley mentioned the gravesites, James thought he could publicize the location of burials to stop the dam. Yet, James failed to understand why Charley and other Natives guarded this sensitive knowledge. "The more I read and question destroying grave yards, the more I believe an issue can be made at Celilo Falls.... [are] there any papers showing it is and has been used as a grave yard," he asked Charley. ${ }^{191}$ Charley did not reply to James. He did not want this information disseminated out into the public where others might misuse it. Instead, Charley jumped in his truck and drove

1948, folder 56, box 1, JJP; Joel L. Shiner, Excavations at Site 35-WS-5 on the Columbia River, Oregon. (Columbia Basin Project, River Basin Surveys, Smithsonian Institution, 1953).

190 Robert Boyd, The Coming of the Spirit of Pestilence: Introduced Infectious Diseases and Population Decline among Northwest Indians, 1774-1874, (Seattle: University of Washington Press, 1999).

191 James to Charley, June 7, 1954, folder 57, box 1, JJP. 
down to The Dalles to have a conversation with the archaeologists in person. "I went over yesterday to Spearfish to where the people were digging on the old camping place of our people," he wrote to James. Charley continued, "I wanted to see their headman... but he went back to Seattle and will be back Sunday." Charley was looking for Warren Caldwell, the field director at the site, but he did not have time to wait. Needing to return to the reservation for a council meeting, Charley would "recommend to the general council that the Yakima tribe institute a suit against The Dalles Dam for destroying the graves and fishing sites.” He clarified,

"[T]hat is why I wanted to see this man [Caldwell] so that we may ask for his help if needed, in court.... We are going to do everything we can to ask our people to go ahead into court.... We may be able to bring out many things to go on court records for future generations."

He jumped back in his truck to return to Toppenish to meet with the Tribal Council. Indeed, Charley wanted to use the graves as a way to stop the project, but he wanted to make sure that he and the descendent community maintained control over the locations of their ancestor's remains. ${ }^{192}$

The Tribal Council moved in a different direction than Charley. Describing the council meeting, where he hoped to use burials as the basis for an injunction, he noted that not enough council members had attended to reach a quorum. "There was no answer to the question of going to court [to] act on the graves and fishing sites that were

192 Charley to James, July 25, 1954, folder 43, box 1, JJP. 
damaged by blasting the dam site when it started in 1952," Charley wrote to James. Charley continued remarking that some of the council members were entertaining the idea of negotiating with the Army Corps towards a settlement plan. Fearing that a negotiated settlement would both compromise the 1855 treaty and the tribe's reserved rights, Charley openly opposed any tribal settlement position. "I would rather go to court on the damage already done and destroyed," he noted as he outlined his position. Charley believed suing for damages could stop the project and "give some of our people a chance to appear before the court and testify to our way of life and our security taken away by the construction of The Dalles Dam." However, several members of the council, unconvinced by his position to sue, moved closer toward a negotiated settlement with ACOE. The results of the meeting were a draw. Because the council had agreed they were willing to sue in the past, and given the fact that the meeting had no quorum and could not reach any decision, it effectively kept Charley's position on the table. Still, the meeting was a disappointment for Charley, who had hoped to go to court swiftly. ${ }^{193}$

Following the council meeting, Charley hopped back in his truck and returned to Spearfish to "visit the archaeologists and make my acquaintance so that in the future we may be able to call on them for help in some shape or form." While the archaeological work disturbed Charley, he still saw the amateur and professional archaeologists as potential allies in stopping the dam. Despite many OAS members who had accepted the

193 Charley to James, July 31, 1954, folder 43, box 1, JJP. 
dam as inevitable, the society was bringing publicity to the professional archeologists and their salvage work. The summer 1954 issue of Screenings carried a note thanking National Park Service archaeologist Louis Caywood for his work documenting petroglyphs in The Dalles area. Additionally, President Howard Galbraith attempted to praise Indian culture, noting that white society had a lot in common with Indians. According to Galbraith, both white and Indian men "work all year looking forward to vacation time when we can go fishing or hunting, or we go out driving on a week end in quest of nature." It is unclear how Charley felt about statements like this, but it is important to note that Charley never took a vacation to hunt or fish. If anything, fishing was a way of life and a responsibility to Charley; a deeply religious experience, not a leisure activity as Galbraith suggested. Galbraith's racist simplification continued, "[s]lightly over half of us moderns like to run around with daubs and smears of war paint slapped on and wearing feathers in head dress." Statements like this were common in Charley's time, and however offensive they might have been to him, he still was willing to try to work with the archaeologists to stop the dam and protect his ancestors' remains. ${ }^{194}$

In late summer, Charley indicated that the tribe's lawyer was attempting to dissuade the council from taking the grave damage issue to court because it might affect

194 Ibid.; Screenings, Vol. 3, no. 6, June 1954, in Poetschat, et. al., The Formative Years of the Oregon Archaeological Society. 
the outcome of an ACOE settlement. Noting that some in the council were trying to schedule a settlement meeting with ACOE in Portland, Charley began distancing himself from his fellow councilmen. "I quit negotiating in 1947 and have planned to go to court ever since to fight for our rights," Charley noted firmly. Providing his own remedy he noted, "What I like my tribe to do is sue the government for authorizing The Dalles Dam without our agreement and they have damaged our graves and fishing sites when they [started] blasting." Reaching out for assistance, Charley then invited James to attend the next General Council meeting in December where the tribe would decide on their final action. ${ }^{195}$

Settlement negotiations between the four Columbia River treaty tribes-Umatilla, Warm Springs, Yakama, and Nez Perce — and the ACOE brought the complex nuances in inter and intra-tribal politics to the surface. Sometimes tribal positions did not necessarily reflect local River Indian families, as seen with Charley's position. Furthermore, with Umatilla and Warm Springs signing settlements as early as 1953, the Yakama used their position to hold off the settlement with the ACOE, claiming a superior right over other tribes to the fishery. This angered both neighboring tribes as well as unrecognized Indigenous residents at Celilo and along the river. However, Wilson Charley's opposition to a settlement also reveals an internal complexity between leaders like Chairman Alex Saluskin, who saw settlement money as a way to develop education, health, and natural

195 Charley to James, August 8, 1954, folder 43, box 1, JJP. 
resource programs on the reservation, and tribal members like Charley, who maintained that settlement would erode the 1855 treaty protections and threaten the tribe's standing. In December of 1954, these issues came to a head when the negotiating committee, with the approval of the General Council, signed a settlement with ACOE for just over $\$ 15$ million dollars for the loss of fishing sites impacted by the dam. ${ }^{196}$

Reflecting on the tribe's vote for settlement, Charley wrote to James concerned that "many of our people are confused on what has taken place at the last general council." He continued reiterating his point that settlement eroded the treaty of 1855. "Jimmie, we already have a contract that the Government that agreed upon in 1855 and if we sign another contract it will weaken the original contact and eventuality make it null and void." He went on to note that while he disagreed, he would honor the decisions of the General Council. However, as an individual, he wondered if " I personal[ly] can stay out of the 15 million and sue the Government individually because my life is my security until death do me part."197 This both reinforced the notion of Indian's personal property rights and exposed the anachronistic thinking of the ACOE that lumped Indian rights into a collective commons.

In Charley's mind, the treaty's protections went well beyond the specific rights to

\footnotetext{
196 Historians Katrine Barber and Andrew Fisher both provide a significant discussion on the complexity of the settlement. Barber, Death of Celilo Falls; Fisher, Shadow Tribe; Dupris, et. al., The Si 'lailo Way; Charley to James, January 31, 1957, folder 42, box 1, JJP; "Indians Accept Celilo Compact" The Oregonian, Dec. 12, 1954, p. 1; "Indians Sign Dam Accord, The Oregonian, Dec. 18, 1954, p.1 and 4. 197 Charley to James, Dec. 30, 1954, folder 42, box 1, JJP.
} 
hunting, fishing, and gathering rights. The right to protect his ancestors and the sacred landscape were implied rights — ones that his ancestors would have enumerated if they thought colonists would end up disturbing graves. Charley had noted in an earlier letter that the protecting graves were an implied treaty right, "we may have to school ourselves on the treaty rights and what it was meant to be forever for the use and benefit for the Red Men." Now with the settlement, he was determined to stay away from the money and continue fighting for ancestral burials left unaddressed by the settlement. ${ }^{198}$

While the 1855 treaty had enumerated explicit provisions for natural resourceslike fish, roots, and berries, the distinction between natural and cultural resources was arbitrary. Even in the 1950s, individuals challenged this artificial separation between cultural and natural resources and Charley viewed sacred archaeological sites as a critical component of his rights to hunt, fish, and gather off the reservation. Former Yakama Agency Superintendent Perry E. Skarra had made a similar connection between human and natural resources. Now working in the Portland area BIA office, Skarra had stated to Charley, "if you destroy natural resources you also destroy human resources [and vice versa]." Impressed by Skarra's more nuanced understanding of tribal resources Charley noted, "you know that is what we have been trying to put out to the public and make them understand."199

\footnotetext{
198 Charley to James, July 25, 1954, folder 43, box 1, JJP.

199 Charley to James, Jan. 7, 1955, folder 42, box, 1, JJP.
} 


\section{Advocating for burials after settlement}

In the midst of the Yakama's settlement negotiations, OAS members continued to excavate ancestral sites with little sensitivity toward human remains. The October 1954 issue of Screenings chronicled the busy activity at Wakemap. Articles illustrated the amateurish excavation techniques and poor field methodology of members. Another article carried a rather insensitive note about excavating a modern burial, which actually was intended to be a joke highlighting how one busy archaeologist had buried his or her own neighboring archaeologist. Beyond the insensitive language regarding how to deal with human remains, the anecdote also illustrates how the rush to dig up artifacts frequently ignored the overall scientific mission - to gain systematic scientific data. People were so busy digging for themselves that they were not even aware of when they were digging in tailings or undisturbed deposits. ${ }^{200}$

OAS's volunteer work at Wakemap happened years before the National Historic Preservation Act (1966), the Archaeological Resources Protection Act (1979), American Indian Religious Freedom Act (1978), and the Native American Graves and Repatriation Act (1990), all of which would protect sacred sites from similar molestation. However, there is evidence to suggest that members both questioned the legality of what they were doing and even knew it was hurtful to Indians. The same issue of Screenings suggested to

\footnotetext{
200 Screenings, Vol. 3. No 10, Oct. 1954, in Poetschat et. al., The Formative Years of the Oregon
} Archaeological Society. 
members working at Wakemap,

In order to compensate for trespassing and the disturbance we have caused, some sort of small token of our appreciation be offered to the Indians in the Wakemap area. Some unwanted article of clothing, a blanket, a box of fruit or candy, or a toy could bring comfort and happiness to these people."

Although Screenings never carried any mention of Charley specifically, he did frequent the site and asserted that his tribe had rights to the site. Moreover, many Indians actually lived on or adjacent to the site and were private property owners who also complained about the excavation. Surely, tokens of candy and blankets were not sufficient when it came to OAS trespassing on an individual's land and robbing ancestral graves and significant cultural sites. An article in The Oregonian reported how the archaeologists had joined with local Native Americans in "preserving remnants of the earliest culture on the Columbia for posterity — and the tourist trade." However, regarding the continued excavations the article incorrectly stated, “The Indians don't like it, but aren't doing anything about it." Further, the article quoted a Native resident of the Spedis Valley who was upset, 'It doesn't look right," stated Charley Kahelamat; “All those things belong to the Indians." Natives were trying to do a great deal to stop the excavations. OAS and the press were aware of the fact that Indians were upset, and yet the digging continued, ignoring the vocal Native opposition. ${ }^{201}$

Despite the incompatible worldviews, Charley still kept fighting. Witnessing first

201 Ibid; Levertt G. Richards, “Archaeologists of Northwest Join Indians in Protest Against Flooding of Wake Map Mound Area in Gorge” The Oregonian, March 29, 1953, p. 35. 
hand OAS's chaotic excavations at Wakemap was devastating. What made matters worse was the Yakama General Council's decision not to sue and take a settlement instead. In a handwritten letter from a meeting in Olympia, Charley suggested that the tribe sue for 100 billion in damages caused by destroying ancestral graves. As matters got more desperate, he revealed that he knew specifically that Chief Colowash, a witness to the 1855 treaty and close confidant to Kamiakin, "who made it possible to stop the Yakima War," was buried near the excavations. Keeping the exact location guarded, Charley feared that OAS members would loot his grave or that "his grave will be inundated by The Dalles Dam Pool." In an attempt to appeal to non-natives to stop the project, Charley drew the following analogy; "[I]t would be just like an Indian flooding George Washington's grave. He was the father of the land, the white mans, and Chief Colowash is the father of the Yakimas and the Northwest." Releasing select aspects of his deep, place-based knowledge was a risky move, but he must have felt that non-natives might better understand the opposition of other Indians. ${ }^{202}$

A few days later Charley discussed Colowash's grave with his father, Jobe Charley, where he learned the 1855 treaty signatories Scha-noo-a and Ka-loo-as (also known as Colowash) were both buried on Grave Island above Spearfish, along with many of their descendants. In fact, Charley disclosed to James that Chief Colowash was his great grandfather. Charley's decision to divulge his highly protected and deeply personal

202 Charley to James, March 16, 1955, folder 42, box 1, JJP. 
family connection to the Grave Island burials suggests the urgency he felt as he faced haphazard burial relocations. Moreover, it also demonstrates his family's association and history along the river. All along, he had known this personal connection but had been reluctant to share it for fear insincere individuals might use it out of context. His family had taught him of generations of ethnographers, scientists, and archaeologists who had studied Indigenous cultures with self-proclaimed authority. Even in the 1950s, he still felt he needed to guard this family history from them. ${ }^{203}$

Beyond confirming Charley's qualifications as a keeper of place-based tribal knowledge, the letter also fully articulated his intellectual position that burials were provisions protected in the treaty and could never be removed or allowed to be inundated. As one of his most important policy arguments, Charley articulated a fluid and elastic reading of the treaty's enumerated protections. "It is important for the public to know what be being done down along the mighty Columbia River," wrote Charley. "This I can say: although you move a dead people's [sic] bones, the principal of a dead person...the deterioration... of the dead person goes down into the earth even if it is a rock island." This point clearly argued that removal of the skeletal remains was not sufficient. Through a universally understood process, an ancestor had become part of the earth and no level of

203 Richard Green, "Yakama Chief Jobe Charley: His Story in Pictures," Whispering Wind 43, no. 5 (2015): 22; Charley to James, March 22, 1955, folder 42, box 1, JJP. A in-depth search of Indian Census records on Ancestry.com illustrates how census takers both incorrectly labeled heads of household and frequently spelled names differently, creating multiple records for individuals. For the complexity of plateau kinship networks see, Hunn and Selam, Nch ' $i$-Wána, "the Big River”; Ackerman, A Necessary Balance. 
excavation could fully recover them. Beyond not building the dam, there was no remedy to honor an ancestral burial by removal. Charley's ancestors had long realized this and created protections that would protect their descendants for all time. Charley continued, "our treaty was based on the laws of the universe... What we do for our rights, privileges, freedoms, and security forever in perpetuity is for our ancestors, for us, and for our descendants. ${ }^{204}$

Charley knew that non-natives did not understand the significance of the treaty as he did. He requested that James write a piece for various papers publicizing the fact that Charley, a grandson of one 1855 treaty signatories was still fighting for the rights to protect his ancestors' graves. He pleaded for James to draw the parallel between George Washington, Abe Lincoln, and Chief Colowash. He asked white readers to honor the treaty "as long as the sun will travel, as long as the Mighty Columbia River shall flow, and long as the white capped mountain shall stand." Indeed, that summer, James wrote to several papers, both local and national, informing editors of the treaty and the situation threatening burials. ${ }^{205}$

Still, framing the issue around the 1855 treaty, Charley did much more than request editorials and articles from the media. Charley drafted a resolution asking the ACOE to agree to honor the treaty's protections for the past, present, and future. Charley

\footnotetext{
204 Charley to James, March 22, 1955, folder 42, box 1, JJP.

205 Ibid.; James to Al Capps, Chicago Daily News, Aug. 13, 1955, folder 61, box 1, JJP.
} 
forwarded a copy to Richard Neuberger, his new political ally who might help in protecting archaeological and burial sites as he had other natural resources. As James placed the letters in the mail, Charley jumped in his truck and was off to a negotiating meeting with the corps specifically over the grave issue. ${ }^{206}$

Wilson Charley placed protecting burials ahead of artifacts and rock art. However, the significance of burials was the last priority to eager OAS members. Professional archaeologists, like Butler, were overextended trying to control the volunteers and did not have the resources to they needed to protect the sites and make himself available to local Natives. The allure and romanticism of artifacts, ironically, made it hard to build public support for Charley's perspective, which centered personally on a connection to the remains of those who had made the very artifacts. While archaeologists continued to publicize their exciting "finds" in local papers, national media outlets seemed less interested in Charley's parallel to the cemeteries of his ancestors and the founding fathers. Exhibits at the Portland Art Museum continued to feature unprovenanced artifacts and were celebrated in Screenings, and OAS field trips to excavation sites continued to build up impressive personal collections of Indigenous material culture. OAS publications on Wakemap and even Emory Strong's own book, Stone Age on the Columbia River, celebrated the archaeological mystery of the mound, the diversity of technology, expression, and a long history of human occupation, but

206 Charley to James, Nov. 5, 1955, folder 42, box 1, JJP. 
almost no acknowledgment of the descendant community and their larger concern to protect their ancestors. ${ }^{207}$

\section{Writing Yakama History}

With many non-natives publishing materials on the history, archaeology, and ethnography of plateau peoples, Charley and the Yakama Tribal Council felt it necessary to write their own history. Earlier in the year Charley, and the entire Yakama Tribal Council, had also begun working on their own history celebrating the centennial of the 1855 treaty. Charley invited James to contribute his artistic skills, producing some line and shade charcoal illustrations for the book. The Yakima Centennial Committee published the book and listed its contributors: Chairman Alex Saluskin, Vice Chairman Thomas K. Yallup, Joe Meninick, Eagle Seelatsee, Tony Skahan, Dave Eneas, Watson Totus, and Wilson Charley. Additionally, the book credited several non-native contributors: Click Relander, the local writer and historic preservation advocate; Dr. Frederick A. Davidson of the tribe's fisheries division; D. E. LeCrone, reservation superintendent; Richard Delaney, of the tribe's forestry division; and Jimmie James for

207 Poetschat, et. al., The Formative Years of the Oregon Archaeological Society; Emory Strong, Stone Age on the Columbia River, (Portland: Binford \& Mort, 1959); Emory Strong, ed., Wakemap Mound and Nearby Sites on the Long Narrows of the Columbia River, Publication No. 1 (Portland: Oregon Archaeological Society, 1959); B. Robert Butler, "The Physical Stratigraphy of Wakemap Mound." To be fair, Emory Strong was not a professional archaeologist, but his publications were more widely read than B. Robert Butler's thesis. Either way, neither credited the descendent community as having any association with the site. 
his art. $^{208}$

The issues surrounding The Dalles Dam affected the language and thematic organization of the Yakama's treaty centennial. Published in 1955, The Yakimas: Treaty Centennial, 1855 - 1955, first opened with a very general overview of American Indian policy and quickly centers on the 1855 treaty negotiations. Later sections include Christian missionaries on the reservation, the importance of reserved fishing grounds, white encroachment, the prospects for a better future as the tribe manages its own timber, and lastly a conclusion by Chairman Saluskin on the importance of family storytelling and memory in keeping the tribe's history.

However, the book's section on treaty negotiations reveals the editorial committee's view on archaeology and their buried ancestors. Their translation of Chief Owhi's testimonial at the 1855 treaty council reflected on the importance of ancestors returning to the earth and thereby to the creator. "God made the earth and it listens to Him to know what He would decide... God looks down upon His children today as if we were all in one body. He is going to make one body of us," Owhi was reported to have said. Humans became the earth, which feeds all future creation. In other words, this important cycle must not be interrupted. Even in the 1855 negotiations, the authors seemed to suggest, tribal leaders gave implied importance to burial protections.

208 Charley to James, March 15, 1955, folder 42, box 1, JJP; Yakima Tribal Council, The Yakimas: Treaty Centennial, 1855 - 1955, (Yakima: Republic Press, 1955). 
The story of Chief Kamiakin's resistance to moving to the reservation ends the treaty chapter while also touching on burial protections. Noting that he refused to move, Kamiakin died "embittered and heartbroken" off the reservation and "was buried on a rocky ledge, in a secret place, in the manner of his people." A tragic end in its own right, the committee took it a step further, injecting this historic precedent to the contemporary struggle to protect burials. Kamiakin's relatives continued to return to his secret burial and perform traditional customs. At one point descendants had returned to decorate the body to find his "head had been severed from the body." Outraged, the committee still said nothing to condemn the unknown perpetrator, taking a higher ground instead. "It has not been recovered so it can be returned, as Owhi explained to Governor Stevens at the Treaty Council of 1855 , to the earth, where we are all in one body [emphasis in original]. " ${ }^{209}$ In other words, the council believed that it was their responsibility to right this and other wrongs, and vowed to work until looters returned these stolen remains to the earth.

The Tribal Council's book came at an in important time as many non-native groups claimed their own expertise on the precontact Columbia River. However, there were many testimonials, oral traditions, family genealogies, and artifacts that evidenced tribal members' deep-seated connection to their history and place since time immemorial. However, most non-native authors of the time rarely looked to these Native-centered

209 Ibid. p. $18-19$. 
sources and were blinded by ethnocentric simplifications that ignored Indigenous history. By writing their own history, Charley hoped that future academics and authors would reference or at least acknowledge the Yakamas' perspective.

Although the tribe had its own history, they still had to get general audiences to read it. Reaching beyond the reservation had long been a problem. Since the beginning of his friendship with James, Charley intermittently spoke of forming an independent tribal radio broadcast where "they can hook up a telephone [for a] really cheap process" and interview people about Indian issues for two hours a day. Charley hoped to promote the book on a show of this sort and to interview politicians and local reservation leaders on issues relevant to Indians. It was a much-needed program, but it never materialized under Charley's leadership. Another option was to take their history to the ACOE and Congress.

Preparing for a negotiating meeting regarding the graves above The Dalles Dam site in November of 1955, Charley drafted a resolution, which needed final authorization by the Tribal Council. The draft resolution clarified the Yakama Nation "has not conceded our treaty rights and privileges." It continued to resolve, "we have agreed to have the remains of our forefathers whom have remained in the vicinity of the Mighty Columbia River... to be removed to higher ground for burial, and may their remains be there forever until Almighty God chooses otherwise.” Additionally, Charley's draft resolved, "that a monument be set up [by ACOE]...and this resolution be engraved on 
this stone of honorable memory of both parties agreement in good faith....As long as the sun will travel, the Mighty Columbia river shall flow, and as long as the great white capped mountain shall stand." He signed the resolution as "the grandson of Chief Colowash... one of the signers of the Yakima Treaty." 210

Charley would not have the opportunity to have this resolution approved by the Tribal Council. The memorial resolution incorporated his recent work on researching and interpreting the 1855 treaty and applied it to the current grave issue. Yet, other political matters shifted the makeup of the Tribal Council; and after December 8, 1955, Charley no longer held his seat. The issues of Charley's departure from the Tribal Council are both complex and have their own important contexts which cannot be fully analyzed here, but it is still worth nothing because he continued his advocacy afterword. The official minutes of the General Council proceedings, likely the best sources to fully tell why he lost his seat, are rightfully controlled by the Yakama Nation and remain understandably guarded. However, correspondence between James and Charley, James and Richard Neuberger, and some of the observations of Yakima journalist Click Relander, who was at the meetings, sheds some light on how Charley's work and advocacy potentially turned into political issues. ${ }^{211}$

\footnotetext{
210 Charley to James, Nov. 5, 1955, folder 42, box 1, JJP.

211 Literary scholar Barbara Monroe covers the tribal election briefly in her work, arguing that the election showcases the distinctive orality of Plateau rhetorical tradition and consensus building, however Charley's association with various allies likely had more to do with it. Barbara Monroe, Plateau Indian Ways with
} 
Consistently, Charley remained a dedicated opponent of accepting any money for the settlement of The Dalles Dam. He feared that the settlement would nullify his treaty rights. His second fear molded into a much more nuanced view of Indigenous property rights; namely that the impact of the dam would not affect each family equally. In other words, the settlement reinforced a colonial projection that tribal resources were a collective commons. As many scholars and generations of Indian fishermen have now shown, fishing stations were not collective but individual property. In Charley’s mind, the adverse effect he would experience by the dam would directly and irreparably harm his fishing income. Those enrolled but not owning fishing stations, he rationalized, had less claim to a loss of income. As Katrine Barber shows, the Yakama Nation not only had the most enrolled members with claims to settlement funds but they also challenged the claims of other neighboring tribes. Federal agencies grossly simplified these tensions as pure intertribal conflict, but the contestation was rooted in a long history of mismanagement of Indian affairs and misunderstanding of identity. Andrew Fisher looks at the same situation and exposes the difference between tribal identity and a kinship identity centered on the river. Given Charley's family history, it is clear that the tensions Fisher and Barber focus on existed at the same time and were often overlapping. ${ }^{212}$ When Charley opposed the settlement, he did so as a Yakama Tribal Councilman

Words: The Rhetorical Tradition of the Tribes of the Inland Pacific Northwest (University of Pittsburgh Press, 2014) 104 - 127.

212 Barber, Death of Celilo Falls; Fisher, Shadow Tribe. 
sworn to protect the treaty of 1855 , as a descendant of Chief Colowash, and as the inheritor of several prime fishing stations along the river. Charley was both ethically bound to protect the treaty and his ancestral lifeway, both of which required protecting select places. Personally, he worried that a lump sum settlement might overshadow these responsibilities and the General Council might become fixated on an equal cash settlement to each member. Charley's public opposition to settlement caught the attention of both of the tribe's more conservative members as well as members that had sold their allotments and moved off the reservation. E.J. Wilton, Chairman of Yakima Indian Association of Washington State, for example, represented the latter.

Charley's association to Wilton was at the crux of his political downfall. In July of 1955, when his term was up, the General Council was unable to reelect Charley by the secretarial procedure (a traditional show of hands). This was because a quorum could not be reached, and Charley later suggested that people's coming in and out of the meeting was an obstructionist plot orchestrated by BIA Commissioner Glenn Emmons to force the tribe to instate a secret ballot and election bylaws designed by the BIA. When the council postponed the vote until late November, E.J. Wilton protested and requested that Commissioner Emmons delay the election until the spring so the off-reservation groups could travel over the mountains safely. Emmons obliged and posted the official election for April, and requested the tribe write official election bylaws. In the interim, Charley worried that any actions of the Tribal Council would be invalid, as he and several others 
had passed their terms. Upset over Emmons's interference in the tribal elections, the General Council convened as planned on December 5, 1955. ${ }^{213}$

Throughout 1955, Charley had met with E.J. Wilton over ways to continue to sue the government in spite of the settlement, using both fishing and burials as key issues. At the December General Council, members accused Wilton of interfering with the tribe's internal election procedures because of his collusion with Commissioner Emmons. Additionally, members accused Wilton of favoring termination, federal taxation, for selling allotments, undermining the treaty of 1855, and dividing the tribe in general. Because of his meetings with Wilton and his open opposition toward settlement, Lawrence Goudy publicly implicated Charley in Wilton's plot in the General Council meeting. Charley clarified, speaking about all his work to protect the treaty and stand up to white men. However, he also noted that the meeting was not legal, as the commissioner had rescheduled it for April. This angered many and some construed it as a supporting statement of Emmons's intervention in the General Council. The members elected Louie Sohappy to Charley's former seat and Charley was officially dismissed from the council. Although Charley disputed the validity of the election, he knew it would be fruitless to protest as it would further suspicion of his support of Emmons's intervention. Over the coming months, Commissioner Emmons brought in Interior

213 "Yakima Indians Battle Federal Move to Delay Annual Election” Oregonian, Dec. 8, 1955 p. 7; Helen L. Peterson, "American Indian Political Participation," Annals of the American Academy of Political and Social Science, Vol. 311 (May 1957),pp. 116 - 126. 
Secretary McKay to hold formal hearings in D.C. regarding the election, and by midApril of 1956, the commissioner declared the election official. The tribe had staved off federal intervention in their elections, but Wilson Charley was one of the political casualties.

\section{"I'm not going to Quit"}

The outcome of the Tribal Council election depressed Charley, although he remained steadfast that he would continue to fight for burial protections. "I am not going to quit...I will still work for the Yakima Nation as I know [what is] best for the old and young of my tribe," Charley wrote to James. Reflecting on his experience he noted, I "learned lots while I was in the Tribal Council, ways and means of how we should protect ourselves." 214 Although most letters to James continued to reference the election for several months, Charley got right back to his work protecting burials.

The first call to action after losing his seat was challenging B. Robert Butler, the lead archaeologist at Wakemap. Charley was alarmed when he first read Butler's column on Wishram Indian culture in the January 1, 1955 issue of The Dalles Chronicle. Butler, who had taken over as the lead archaeologist at Wakemap Mound in May of 1955, began publishing a weekly column entitled "Dirt Gets in Your Eyes," which ran from January to May of 1956 in The Dalles newspaper. Writing as the expert authority on Native culture in the area, Butler's first column opened with the question "Who are the Wishram

214 Charley to James, December 21, 1955, folder 42, box 1, JJP. 
Indians?" Butler stated, "the main village of the Wishram was probably at Spearfish...formerly called Spedis.” The column was intended for Butler to share his professional knowledge with the public, to encourage volunteers to assist in excavations at the sites, and to raise awareness for a natural history museum in The Dalles to house all the removed artifacts. Columns covered Butler's understanding of Wishram culture, rites of passage, diet, spiritual customs, burial rites, and storytelling, all of which he had likely gleaned from limited ethnographic sources, and from talking with members of the descendent community like Charley. The paper easily broadcast Butler's voice as a professional, while Charley's years of activism remained muted. ${ }^{215}$

What upset Charley was that Butler oversimplified the area and had not asked for input, which he would have gladly given. "We are not quite agreeable with what he is putting in the paper," Charley wrote to James. Butler's oversimplification that Wishram was the main village neglected to incorporate the linguistic and cultural diversity as well as local inhabitants personal property — some of the unique characteristics of the region. Charley, steeped in this cultural complexity, knew that "from Spearfish down to Big Eddy, there must have been over twenty different villages, each one was occupied one time or another in the past, and they all have Indians names." Butler had applied narrow sources writ large to one of the most complex continuously inhabited sites in North

215 B. Robert Butler, "Dirt Gets in Your Eyes" (weekly column) The Dalles Chronicle, January 1, 1956, p. 5. 
America. While Charley was pleased to see others essentially proving his long assertion of the area's Indigenous occupation, he was upset because Butler did not know important details that perpetuated further misunderstandings. Given all Charley's earlier work to contact archaeologists with the personal information about his ancestor Chief Colowash, the fact that they ignored him was a missed opportunity to publish a personal and much deeper significance of these sites in the local newspapers - a point that most archaeologists continued to miss until the 1990s and still struggle with to this day. ${ }^{216}$

Butler continued his column and encouraged volunteers to come out and help excavate Wakemap. After several years of patchwork projects, the pockmarked site was heavily disturbed and it was difficult to delineate an intact cultural stratigraphy. In late February, Butler published two columns on local burial practices pointing out the burials he had excavated at Wakemap and nearby. Additionally, he called out the extensive burials on islands in the river. These burials were intentionally set in the river islands as a way for individuals to ascend to the upper world. Butler specified the universality of burial culture, "[W]e both honor our dead," he wrote. However, drawing no parallel to his own work removing these graves, he ironically concluded his column with, "What some people do to their dead amazes and sometimes horrifies others." Certainly, Butler's

\footnotetext{
216 Charley to James, Jan. 7, 1956, folder 42, box 1, JJP; B. Robert Butler, "Dirt Gets in Your Eyes" (weekly column) The Dalles Chronicle Jan. 8, 1956, p; Jan. 15, 1956, p. 2; Jan. 22, 1956, p. 4; Jan. 29, 1956, p. 2; Feb. 5, 1956, p.2; Feb 12, 1956, references burial islands; Feb 19, 1956, p. 5; Feb 26, 1956, p.; March 4, 1956, p.; March 11, 1956, p.; March 18, 1956, p. 5; March 25, 1956, p. 2; April, 1, 1956, p.2; April, 8, 1956, p.; April, 15, 1956, p. 19.
} 
treatment of ancestral burials horrified Charley. ${ }^{217}$

\section{The Need for Law and Regulation}

With Charley off the Tribal Council, James came to play a far more important role as Charley's conduit to allies. Once again, James sent a letter to President Eisenhower trying to appeal to Ike personally. "The Burial Grounds that are soon to be flooded are sacred and holy to the Indian People, because they hold their EisenhowersWashingtons_-Lincolns and Jeffersons. These Burial Grounds are Arlingtons to them," wrote James as he tried to touch on Ike's patriotic side. Pleading for action James continued, "The back to the earth bodies, that have become part of the earth, cannot be removed. The greatest Chiefs and Warriors... of centuries past are now 'thoughtlessly' being termed "just yardage' to be excavated." James point, that the ACOE was disrespecting burials and considered them "yardage," applied to both construction and archaeological teams. In asking the president to act, "Do not leave it to some bureau," James plea pointed to the level of distress that both he and Charley were feeling regarding this particularly sensitive issue.

What is most significant about James's letter to the president is that he articulated for the first time a need for law or regulation of Indian burials. "Laws and principals are involved now and there should be protection for their Burial Grounds. There is no price...that can be placed upon these burial grounds any more than could a price be put

217 B. Robert Butler, “Dirt Gets In Your Eyes,” The Dalles Chronicle, Feb. 5, 1956; Ibid., Feb 12, 1956. 
upon the plot where your parents are at rest," James wrote to the president. ${ }^{218}$ Charley requested that James write Neuberger to ask about any laws governing cemeteries on federal land. Neuberger obliged and wrote to the National Park Service but the request took months for a reply. "We do not know of any general laws that govern and protect graveyards on federal property," wrote acting NPS Assistant Director Henry Langley. “However, during Mr. Horace Albright's tenure...he established...the service policy concerning burial plots or cemeteries within National Parks," clarified Langley. The policy stemmed from the Great Smoky Mountains National Park and vowed to "do everything within our power to keep cemeteries intact and that parties may go to and from the cemeteries with all freedom of action." Further, the policy recognized "there may be some who have moved out whose family burial plots are in the same cemeteries and who therefore may wish to be buried in the same cemetery as their kinfolks."219 James and Charley must have been excited about the potential to apply this policy along the river, but as they brought it to the ACOE official's attention, the Corps noted that they and not NPS had jurisdiction over the river. ACOE would only relinquish jurisdiction of sites needing archaeological excavation to NPS, administrator of the River Basin Survey program. At each corner, ACOE favored policies that kept the dam on schedule. ${ }^{220}$ James wrote to President Eisenhower expecting the White House would ignore

\footnotetext{
218 James to President Dwight D. Eisenhower, January 25, 1956, folder 63, box 1, JJP.

219 Henry Langley to Neuberger, July 6, 1956, folder 24, box 1, JJP.

220 Frances McBride to James, July 21, 1956, folder 35, box 1, JJP.
} 
him. However, Richard Neuberger took this plea more seriously. "Will you please look into the grave situation...I am sure there would be steps taken if it were the white mans," James wrote to Neuberger. "I have seen Archaeologists digging up there...they found human bone parts down over 12 feet...there has been enough shame created up at Celilo Falls without disregarding the Indian's burial places," noted James. Involving Neuberger, James hoped to cash in some of the political capital that they had invested in his campaign. Neuberger promised to "secure adequate appropriation," and hoped that NPS "will bear these things in mind in planning and surveying the work that needs to be done." In other words, graves would not stop the project and Congress could consider a future policy amendment later. Neuberger wrote to Senator Carl Hayden, chairman of the Senate Appropriations Committee, requesting funds for additional archaeological salvage — specifically petroglyph relocation and funds for Wakemap Mound. James received the letter and saw there were no funds or mention of Indian grave protections in the appropriations. However, James was not the only Oregonian writing to Neuberger regarding the ancestral sites at Celilo. 221

\section{Relocation of Burials Ignored Charley}

While the NPS had some rough policy, the Corps was completely ill-equipped to consider burials. ACOE tactics, like outright intimidation and bureaucratic runarounds

221 James to Richard Neuberger, February 21, 1956, folder 63, box 1, JJP; Neuberger to Carl Hayden, February 27, 1956, folder 8, box 18, Richard Neuberger Papers, Ax 078, Special Collections \& University Archives, University of Oregon Libraries, Eugene, Oregon (hereinafter RNP). Neuberger to James, March 15,1956 , folder 8 , box 18 , RNP. 
toward Natives, made any kind of negotiation lopsided toward the Corps. In March of 1956, a committee representing the Yakama Nation met with the ACOE to identify burials on Grave Island, just east of the dam site. Colonel Merie Lietzke of the Corps Real Estate division stated, "[T]he Yakima Tribe represent the principal interest.... We realize that members of other tribes may be buried there, and our planning provides for consultation with surviving relatives as positive identification progresses." Requesting each tribal member essentially "prove" his or her affiliation to a burial was problematic at best. Lietzke required "a step by step process" that continued "until all possible physical information is first assembled." With unaffiliated Indians at Celilo, and so many overlapping connections to other tribes in the area, as well as those living on other reservations, it was impossible to conclusively prove a singular tribal affiliation to each burial — especially because may of the tribes did not exist as cohesive political units when individuals had been buried. "Chief Tommy Thompson would therefore like to be informed [of the process]," wrote Barbara McKenzie to the Yakama's attorney. Simplifying tribal identity to a single "check the box" identification and shortening the process to claim affiliation were both strategies that suggested the ACOE wanted to expedite the burial relocation program and cared little about actual Indian concerns, or even the sensitivity of disclosing a burial location and the issues of contested tribal affiliations. ${ }^{222}$

222 Merie E. Lietzke to Hogan and York Attorneys at Law, March 28, 1956, Celilo Falls Relocation Project 
Among local Native Americans, there was not a singular view or stance on how to protect, or even who had jurisdiction over, these burials - even though the Corps wanted a simplified solution. George Cloud, interviewed by Barbara McKenzie, indicated his concern for the burials on Grave Island. Specifying that he did not know if Natives had used the island in recent years, he consented to have the bodies removed and relocated to an upland cemetery. It is important to stress that Cloud did not support moving the bodies per se. Instead, he based his consent on the fact that he did not know of any recent burials. It was his personal feeling, not necessarily a statement for all Natives. ${ }^{223}$ With one part ambiguity, one part universality, statements like Cloud's were just what the ACOE wanted. McKenzie asked Percy Othus, the Corps professional negotiator, what he thought of the burials on Grave Island. Othus stated that, "No particular plan had been made as it was felt that this was a very old burial ground and was of little concern to the people of the area now." Othus commonly used statements like Cloud's simplistically and out of context to fulfill his ACOE mandate: to get the local Indians to sign away rights and protect the Corps from any legal recourse. On numerous occasions, Othus showed up at Tommy and Flora Thompson's home attempting to sign agreements. Negotiators were trying to get a few Indians to say that these burials were

\footnotetext{
Records, 1948 - 1957, mss 2678, Oregon Historical Society Research Library; Hogan and York to Lietzke, March 23, 1956, Celilo Falls Relocation Project Records, 1948 - 1957, mss 2678, Oregon Historical Society Research Library.

223 McKenzie to J.P. Elliott, Feb. 28, 1956, Celilo Falls Relocation Project Records, 1948 - 1957, mss 2678, Oregon Historical Society Research Library.
} 
not significant, and thereby apply this statement giving ACOE carte blanche authority to destroy other burials not disclosed by the tribes. ${ }^{224}$

Charley was already aware of the Corps effort to coerce. He had long been skeptical of any negotiated settlement. Charley, now off the council, was even more reticent to disclose any information to the Corps on his family ancestry or genealogy, even though he specifically knew his grandfather was buried on Grave Island. The Yakamas' own treaty centennial history had only begun to address the need for a tribalcentered history, in part to combat the Corps' strong-arming negotiations to their own advantage. Speaking about how long his ancestors had resided in the area, and his right to protect their graves, Charley acknowledged, "Some of our people are funny and cannot seem to look way ahead and can only see one side of it and are blind to the main facts." Charley encouraged Jimmie James to approach the Tribal Council, specifically Louie Sohappy (who had taken Charley's former seat), to draft a statement on the rights to the burials and archaeological sites in question. "In your letter," Charley wrote, "make it look like we Indians will benefit from the history. Cause it is awful hard to make them see it because so many white people in the past have tried to write a history of the red men." $\mathrm{He}$ continued stressing the importance of his perspective: "What the red men tell about the

224 Ibid; Barber, Death of Celilo Falls. 170 - 172. 
history is the full truth and the white man will shy away." 225

Charley's caution in how he presented information both illustrates how a tribalcentered history could be beneficial in negotiating with the Corps, but also how difficult it was for tribal members to both find the documents and craft the narrative with the scarce reservation resources. Individual allies like James and Click Relander were incredibly helpful in producing this work. Still, individual Natives kept much of their documentation and traditional knowledge close to home and spent their own time and money collecting in the shoebox under the bed. This position was justifiable as many in the tribe were skeptical of sharing this sensitive information with outsiders. ${ }^{226}$

\section{Fixated on Artifacts, Pictographs, and Petroglyphs}

Few non-natives seemed to care about the ancestral burials, or what Natives had claims to them. A narrow interest in material artifacts and romantic ideas about rock art once again muted Native's concerns. While James and Charley had been seeking Neuberger's support to stall the dam over the burials, OAS president Emory Strong and B. Robert Butler had already convinced Neuberger that the Gorge sites simply needed salvage excavation. Focused on petroglyphs and pictographs, Strong noted that the

225 Charley to James, March 10, 1956, folder 42, box 1, JJP. Local newspapers also covered the burial relocation. See, "Army Engineers Announce Reburial Plans," The Oregon Journal, Nov. 12, 1956; "Relocation of Indian Graves Costs \$60, 340," The Oregon Journal, Nov. 29, 1956; George Lindsay, "Bones of Ancient Redmen Reinterred," The Oregonian, Jan 18, 1957 p. 11; Ann Sullivan, "Operation Whirlybird Moves Ancestral Bones," The Oregonian, Feb, 9, 1957, p. 1.

226 Wilson Charley frequently noted how difficult it was to retrieve federal records and store them on the reservation. With no funds for secretary or even filing cabinets, Charley kept his own documents, but janitorial staff often threw them in the trash. See, Charley to James, Oct. 4, 1954, folder 42, box 1, JJP. 
National Park Service, in partnership with Dr. Luther Cressman and Dr. Douglas

Osborne, had requested $\$ 10,000$ to remove "the more spectacular specimens" to be flooded by the dam. Strong requested more funds. "As a student of Oregon history I am sure that you know potentialities of The Dalles area are unequaled anywhere," Strong wrote to Neuberger. Neuberger replied that he would confer with the Senate and offered to make a statement on behalf of OAS on the floor. ${ }^{227}$

Strong quickly drafted his statement for Neuberger to read. Describing the formation of OAS, Dr. Cressman's and Dr. Osborne's salvage work, and the historical importance of Celilo Falls, Strong requested that, "sufficient money be appropriated to cut away the art specimens from the cliffs for removal." He noted the pictographs and petroglyphs could be "a great tourist attraction.... true expressions of an artistic urge." While Strong meant to honor the long cultural history of the region, his ignorance completely left out any sense of Indigenous ownership of these artifacts or recognition of Indigenous knowledge of the past. Further, Strong noted that salvage was actually a favorable outcome because the location of these features was "little known except to the amateur and professional archaeologist.” Journalist Fred W. Vincent echoed Strong's privileged assessment that the removed panels would allow greater tourist potential, especially because "present day Indians here in the West with very few exceptions,

227 Folder 8, Box 18 of Richard Neuberger's papers contains several important letters that demonstrates the divergent funding between burial relocation and petroglyphs. See, Emory Strong to Richard Neuberger, March 2, 1956, folder 8, box 18, RNP; Neuberger to Strong, March 20, 1956, folder 8, box 18, RNP. 
disclaim any knowledge of the petroglyphs and pictographs despite the fact that a number or their symbols are widely used in tribal ceremonies and rites." Strong was certainly aware of Charley through James. The push to remove the rock art and ignore Natives concerns suggested to the public that contemporary Native Americans like Charley had no clue about these features. It was a strategy employed by the Corps and archaeologists to discredit Native's claims to their own past and rationalize removal. ${ }^{228}$

Realizing that burials were not tourism material, Neuberger became fully enamored with helping to save the artifacts and rock art threatened by the dam, but funding the operations was not a simple task. B. Robert Butler visited his office in April and requested the senator keep him apprised of the Corps' ongoing construction, particularly because his crews tended to get to sites after the construction had begun. Butler noted his column "Dirt Gets In your Eyes" had led to some personal checks to fund excavations, but he still needed federal appropriations. Fortunately for Butler, Senator Morse introduced a bill on April 23, 1956, which included $\$ 25,000$ for archaeological research at The Dalles Dam site. "I am extremely happy to be able to report the Senate approval of this proposal," Neuberger notified Butler. The news traveled quickly. W.S. Nelson, manager of The Dalles Chamber of Commerce, congratulated Neuberger and Morse for their work in funding the salvage of artifacts that

\footnotetext{
228 Strong to Neuberger, March 26, 1956, folder 8, box 18, RNP; Fred W. Vincent, "Pictograph to Petroglyph," Northwest Living Magazine, April 22, 1956, pp. 12 - 13.
} 
would be displayed in a future natural history museum in The Dalles. ${ }^{229}$

Despite James's and Charley's work with Neuberger, there were no line items in the appropriations to support burial protection or working with the tribes. Early in the year, James had requested that Senator Morse include language to address the local tribes' concerns regarding their graves. "I appreciated your letter of March $24^{\text {th }}$ in which you stressed the point that the Indian people should be consulted with respect to what they wished saved at the reservoir of The Dalles Dam," Morse wrote to James. Studying each bill and letter closely, James saw no language pushing for tribal consultation-only an acceptance that sites could be simply excavated by OAS volunteers and university archaeologists. Furious and betrayed, James fired off a scathing letter to Neuberger. Commenting on Morse and Neuberger's appropriation, he wrote, “Today I believe I saw one of the Most [sic] depressing things that ever came to my attention.... I have believed in the past, the Man's cemeteries were sacred." He continued to draw a parallel between the Indigenous burials along the river to Arlington National Cemetery. Shaming Neuberger for perpetuating this vicious cycle, James reminded him that decades back, when the railroad line went straight through a graveyard at Celilo, elders had protested and had been promised it would never happen again. In conclusion, James pleaded, "it would not be asking much to stop the construction for the dam, if need be, until the

229 Elizabeth Ducey to Neuberger, April 28, 1956, folder 8 box 18, RNP; Neuberger to B. Robert Butler, April 30, 1956, folder 8, box 18, RNP; Wayne Morse to James, April 24, 1956, folder 28, box 1, JJP; W.S. Nelson to Neuberger, April 27, 1956, folder 8, box 18, RNP. 
Indian people can be contacted and treated like the white skinned people in caring for their dead."'230

Richard Neuberger did not reply for several days. Partly it was because he was so busy coordinating with OAS and B. Robert Butler over funding the salvage work. On May 9, 1956, Neuberger took to the floor and read an extension of remarks entitled "Preservation of Remnants of an Ancient Culture on the Site of the Dalles Dam." Briefly, he thanked the senate for approving appropriations to carry out the salvage excavations and asked for unanimous approval to print Emory Strong's support letter and Fred W. Vincent's petroglyph article in the Congressional Record. He also requested to add excerpts from James's angry letter stating,

Jimmie speaks... with profound sorrow_-sorrow for the desecration of Indian graves, sorrow for a people who must lose this intimate association with the past, sorrow for a people who in their rush to possess the earth, rudely trespass on the chambers of the dead.

Dedicating thirty-two paragraphs to reprint Vincent's article, and eight paragraphs to Emory Strong's letter, Neuberger distilled James's letter into one cobbled together sentence: "Indian cemeteries are just as sacred and have the same right of protection as those of the white people."231

Neuberger's acknowledgment that The Dalles Dam project desecrated Native

\footnotetext{
230 James to Neuberger, April 26, 1956, folder 8, box 18, RNP.

231 Richard L. Neuberger, Extension of Remarks, "Preservation of Remnants of an Ancient Culture on the Site of the Dalles Dam." Congressional Record, May 9, 1956, A3726, copy in folder 8, box 18 RNP.
} 
American graves was purely symbolic. Finding funds for archaeology, while a substantive solution, highlights the disregard for burials. The most ironic aspect was the quote attributed to James, because by funding archaeology, petroglyph removal, and not slowing the project to consult with tribal officials, Neuberger and Morse effectively proved the opposite of James's quote - that Indians deserved the "same protections as those of the white people." Neuberger believed that he had done all he could and stated the injustice for the Congressional Record. Forwarding extra copies of his statement to James, Neuberger noted: "you may want to share this with some of your Indian friends." A patronizing statement, on some level, it assumed that Indians were incapable of modernization. It also suggested that Natives were a barrier to progress and there was nothing to do but accept the tragedy. ${ }^{232}$

\section{The Commodification of Indigenous Knowledge}

To a certain extent, various archaeologists and federal officials had commoditized Indigenous knowledge to reinforce their own desire to develop the river. Certainly, Neuberger and Morse could have done more to advocate for burial protections. Regarding the petroglyphs, the Corps had indicated to Neuberger that they were willing to provide technical assistance to the NPS for their removal. With the scope and breadth of work remaining, OAS and Butler needed more volunteers to conduct the salvage. Morse and Neuberger continued to push various agencies involved to make sure the

232 Neuberger to James, May 10, 1956, folder 24, box 1, JJP. 
$\$ 25,000$ was spent only on projects immediately to be flooded by the dam. Both Oregon senators showed their flexibility and creative fundraising to get the sites excavated. Yet, at each turn, these individuals were aware of Charley's detailed connection to burials simply used his perspective to support mitigation and not preservation. ${ }^{233}$

Neuberger and Morse had turned the archaeological sites into a political tool for their own constituents. A volunteer from the summer season at Wakemap wrote Neuberger praising B. Robert Butler and OAS and requesting to continue the excavations into the next year. She was sincere. Her experience was "profoundly moving," particularly "because of the treasures I was introduced to," wrote Selma Hymen of Portland, Oregon. She continued; "There is terrific urgency that I felt for recovering these things before they are forever lost." Proposing a solution to future dam development, she "realized the necessity also for a long range program to precede other such [dam] projects." Neuberger responded to her proposal for future archaeology projects favorably, noting that he had secured the $\$ 25,000$ for excavations and that he had worked closely with B. Robert Butler. He also reminded her that it was an election year, suggesting that he viewed this as one of his great political accomplishments. ${ }^{234}$

The dam had become a boon for artifact hunters and professional archeologists

233 D.H. Foote to Neuberger, May 17, 1956, folder 8, box 18, RNP; Morse to Conrad Wirth, June 6, 1956, folder 8, box 18, RNP; Walter P. Schuck to Morse, July 30, 1956, folder 8, box 18, RNP; E.T. Scoyen to Neuberger, Aug 6, 1956, folder 8, box 18, RNP; Morse to Neuberger, Aug. 9, 1956, folder 8, box 18, RNP. 234 Selma Hymen to Neuberger, Sept. 17, 1956, folder 8, box 18, RNP; Neuberger to Hymen, Oct. 1, 1956, folder 8 , box 18 , RNP. 
alike. In the spring of 1956, a D-8 dozer blitzed straight though a site to allow pothunters quick access to the artifacts they valued. Butler tried to rein them in but could only use empty agreements that required amateurs to collaborate with professional archaeologists who could at lease photograph and sketch the looted artifacts before they disappeared to private collections and black market trade. In the final months before the floodgates closed, relic hunters picked over as much as they could. Local Native Americans, like Martha Skanawa, were deeply hurt and embittered by what Butler had done at Wakemap. Butler reflected that, it "would have been a very real pleasure to have accomplished a successful relationship with Martha Skanawa. She absolutely refused further contact between us." What is most significant here is Butler's own ignorance of his powerful position and how he too had commoditized Indigenous knowledge. Butler's M.A. thesis, completed in 1960, noted the association of Grave Island burials to Chief Colowash, information that he likely received from Charley's letters. Butler never acknowledged Charley's authority, simply accepting that sites had to be excavated. In his final report, Butler simply footnoted the area's association to Colowash's grave, albeit without any recognition of the source of this information. While Butler rose to prominence in his own field, his actions ultimately damaged ties between archaeologists and the Native community — which had approached him for help first. ${ }^{235}$

\footnotetext{
${ }^{235}$ Hub Strain, "Hunters Race Columbia Dam," Northwest Magazine, Oct. 28, 1956; "A Good Arrangement," The Dalles Chronicle, March 18, 1956, p. 4; “Operation Last Chance: Wakemap Project
} 
Returning to the river, Charley again asked, "Dr. F.A. Davidson take a picture of the dam workers taking out Wasco Island." Comparing earlier photos in 1952, which had shown "no damage done," the 1956 photos showed the workers "blasting the Islands at Celilo Falls." The photos, he hoped would prove, that "the [BIA] area office should be responsible for all that...they wanted the dam built, and they supported it in every way." 236 As the floodgates closed, the dam inundated the oldest continuously inhabited site in North America. Yet, the controversy surrounding these archaeological and burial sites still needed addressing. Not every site was fully salvaged. Not every burial relocated. Not every pictograph and petroglyph removed. Today, much endures under the dam's slackwater pool of progress. Many sites and burials remain, known only to select members of the tribe. Despite the reminder of the betrayal, Charley would be proud of those today who guard that knowledge and that they continued to find ways to survive.

Topic of Article," The Dalles Chronicle, April 15, 1956; "Officials Endorse Education Angle at Wakemap Dig" The Dalles Chronicle, May 6, 1956, p. 2; B. Robert Butler and Martha Skanawa is quoted in Virginia Butler, "Relic Hunting, Archaeology, and Loss of Native American Heritage at the Dalles"; B. Robert Butler, "The Physical Stratigraphy of Wakemap Mound."

236 Charley to James, Oct. 27, 1956, folder 42, box 1, JJP. 


\section{Chapter 4}

\section{"We can still fish...we can use new methods": Surviving after The Dalles Dam}

"We [Natives] never depleted the salmon.... mother nature always comes through.... if we accept the whiteman's ways of conservation the salmon will really be depleted forever."

—Wilson Charley to James James, April 8, 1958

"In the interests of conservation we are unable to authorize a gill net fishery in the Columbia River above Bonneville. You will appreciate that such operations could well destroy the Fishery resources of the Columbia River. We are certain the Indians do not desire this result." 237

—Milo More to James James, October 10, 1959

On March 10, 1957, Wilson Charley stayed home. That day, photographer Ray Peirce pointed his camera at Celilo Falls and captured a rising slackwater pool of progress as it flooded dozens of ancestral sites and the aboriginal economic center of the Columbia Basin. Like many local Native Americans, Charley chose not to witness the closing of the floodgates at The Dalles Dam. To see the loss was too painful. Yakama scholar Michelle M. Jacob notes that the dam's “impact [to] the traditional Yakama economy was immediate and devastating, directly resulting in massive unemployment, dramatic increases in hunger and poverty, and unmeasured detriment to Yakama people's mental health and well being." In her recent study of Yakama cultural revitalization,

237 Milo Moore to James, Oct. 21, 1959, folder 39 box 1, JJP. 
Jacob positions the rippling effects of flooding Celilo and an "intergenerational historical trauma," as a "soul wound" still felt today among tribal members. ${ }^{238}$

The Dalles Dam not only altered the course of the river, it also affected Charley and his family in deeply personal ways. This chapter follows Charley's life and leadership after The Dalles Dam left his life in ruins. Tracing the continuing tensions between tribal and individual rights, Charley articulated new strategies to survive economically and culturally on the post-dam river by focusing on four strategies: proposing alternatives to the settlement money, articulating post-dam economic development plans, suing for individual compensation, and shifting Native fishing policies. Charley confronted a changing landscape with his own changing set of strategies. He set the stage for future fishing rights cases and the subsequent establishment of the Columbia River Intertribal Fish Commission. Although he encountered significant resistance from state officials and federal policies, his persistence paid off. Contemporary Native leaders now have a permanent seat at the table, alongside federal officials, regarding the management of the river. Charley's vision in this final point may be his most important legacy. 239

\footnotetext{
238 "Echo of Water Against Rocks | University of Oregon Media Channel," accessed September 7, 2016, http://media.uoregon.edu/channel/archives/88; Jacob, Yakama Rising, 10-14.

${ }^{239}$ Ibid.; Jacob, Yakama Rising, 10-14.
} 


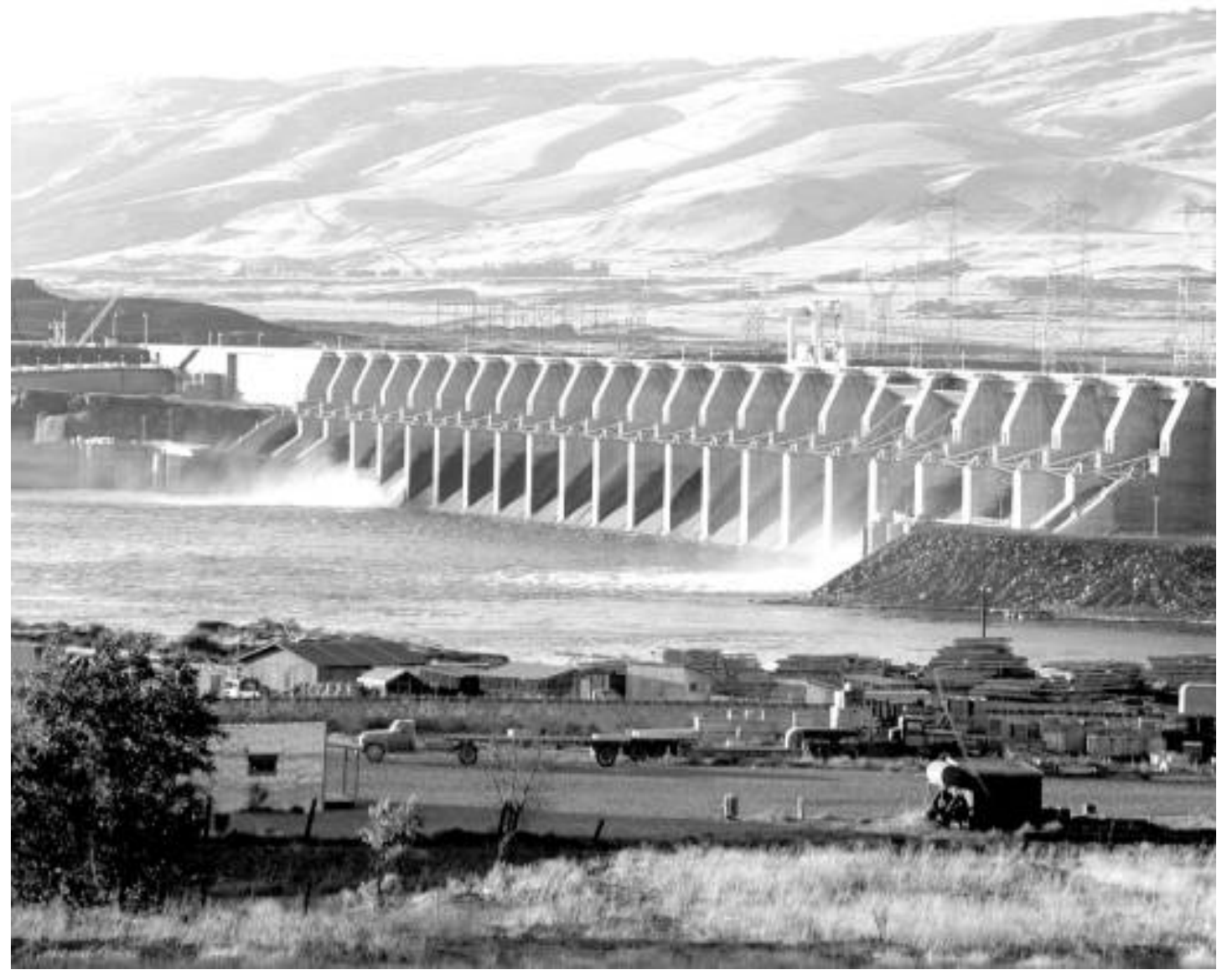

Figure 10: Photographer Russell Lee captured The Dalles Dam in 1958. Wilson Charley's fishing shed and the Lone Pine Indian camp are front and center in the foreground. Image from the Ben Maxwell Collection, Salem Public Library, Salem, Oregon.

The Dalles Dam was devastating, but Charley's persistence and long-term planning continued. He looked to the best possible outcome, that he could still practice his treaty rights by gillnetting and would find other ways to supplement his income. In 1956, a year before the floodgates closed, Charley scouted an alternate fishing station 
underneath The Dalles Bridge with his friend Joe Eastbrook. The location, a few hundred yards west of the Lone Pine camp and a half-mile below The Dalles Dam would prove to be an important fishing station for him and future Native fishers-in fact, one can often find Native fishers dip netting there today. "Even if the dam goes in, we can still fish there and at other places outside of this one," noted Charley in the final days before the dam flooded Celilo. Preparing for the dam's dramatic flooding of the ancestral fishing stations, Charley prophetically announced, "We can still fish...we can use new methods such as boats anchored out and dip from boats. The water will be slow so we could make big mesh nets."240

After the inundation, it took nearly a month before Charley returned to the river. The morning of April 4, 1957, he went fishing at Lone Pine. The experience left him feeling uneasy. There was a catch, but it was awfully poor. "Our biologists told us ten years after The Dalles Dam there won't be any salmon, but I think he is only half way right," he wrote predicting a possibility for some salmon fishing in the future. Charley had long challenged the narrative of technological optimism promoted by dam planners and developers — namely that hatcheries and ladders would maintain fish populations. After his first time fishing the post-dam river, he saw first hand the reductions in the catch. At the same time, the fact that he at least caught something must have provided a

240 Wilson Charley to James J. James, May 13, 1956, folder 42 box 1, JJP; Charley to James Sept. 10, 1956, folder 42, box 1, JJP. 
glimmer of hope that fishing might have a future. If Native fishermen could shift their fishing methods and kept state regulators off their backs, they might have a chance at a stable catch.

However, the catch would not provide a living. Thus, Charley began to develop business proposals that would relieve cash-starved families left hungry by the dam's watery void. Yet, at each turn, federal officials stopped his proposals by either controlling individuals through administrative red tape, or by controlling the flow of settlement funds to the tribe and then to individuals. ${ }^{241}$

\section{Settlement Funds}

In January of 1955, the Yakama Nation had accepted a fifteen million dollar settlement proposal, assessed on a per capita basis, for loss of fishing grounds-over two years before the dam flooded Celilo. In his earlier work, Charley had remained adamant that the tribe not accept settlement money and instead dictate their own economic ventures. On the one hand, Charley feared federal officials would construe a negotiated settlement as a total buyout of Native individual's rights. In his mind, the settlement money was blackmail. According to his understanding, the tribe would have to prepare for termination before they could ask the BIA to release the money. Personal divisions about termination, settlement, and individual versus tribal property were complex issues,

241 Charley to James, April 4, 1957, folder 42, box 1, JJP; F.A. Davidson to Wilson Charley, Jan. 22, 1957, folder 42, box 1, JJP. 
but the BIA painted these important debates as simple intertribal factionalism. Because the BIA held the funds, Charley wrote, "they [BIA] let the Indian people go ahead and fight amongst themselves, and when the final payment is made they said well we [BIA] got the money now and you are going to do what we want you to do or you people do not get [it]."

Charley thought that the settlement would reinforce federal paternalism and promote the idea of a tribal commons where all tribal members held equal rights to the fishery whether they had ancestral rights or not. The BIA's distribution of the cash on a per capita basis among tribal members undermined traditional ownership rights. With termination the BIA's ultimate goal, it was reasonable for Charley to see this as one way to undercut the traditional authority of the river fishing families. Indeed, as historian Katrine Barber writes, "The disbursement of settlement funds was not a straightforward proposition.... [It] was fraught with meaning beyond what could have been the simple process of paying for usurped property." 242

There had been alternative proposals — and not just from Natives. During a time in federal Indian policy where Congress formulated termination to "free" Indians from a constraining federal bureaucracy, the dam had created an economic void that put increasing numbers of Indigenous people in more extreme poverty. "My people went from a rich culture, to rags of progress," lamented Charley months after the dam went

242 Charley to James, July 16, 1958 folder 43 box 1, JJP; Barber, Death of Celilo Falls, 155-82. 
online. For Congress, this was not an unforeseen outcome. In January of 1957, a nonnative resident of the Yakima Valley questioned the cash settlement in a letter to Senator Richard Neuberger: "Why instead of a cash settlement to the Indians, were they not given the right to take a yearly [average] amount of fish off the Dalles Dam fish ladder," he asked the senator. He understood that "the Indians were reimbursed for loss of livelihood, not because of sport fishing." Further, he wondered, "Would it not have been more practical to furnish the continuation of their livelihood through fishing?" Neuberger replied noting he would forward the letter to the Army Corps of Engineers. However, neither he nor the ACOE ever fully addressed this proposal, much like Charley's earlier compromise to receive a percentage of power generation from the dam. ${ }^{243}$

Over a year after the dam had flooded his fishing stations, the fifteen million dollars of settlement money was still nowhere to be seen. Unable to obtain reliable income from berries, fishing, or logging, Charley traveled to Madras, Oregon where he took a job hauling potatoes to a processing plant. The lack of economic opportunities resulting from the dam and curtailment of Indian service programs pushed many Indians, including Charley, to migratory farm labor. Again, Charley asked Senator Neuberger for help. He reminded Neuberger that fishing was not a hobby but his occupation. "Our hunting and fishing rights were neglected by our overseers when the mountain areas were

243 Glenn Luening to Richard Neuberger, Jan. 1, 1957, folder 6-7, box 11, RNP; Neuberger to Luening, Jan 16, 1957, folder 6-7, box 11, RNP; Don O. Foster to Neuberger, July 16, 1957, folder 6-7, box 11, RNP. 
made national forests... the mountain areas were set aside in the treaty," clarified

Charley. Indeed, Charley's great grandfather Chief Colowash had secured access to resources and a viable income in the 1855 treaty. These reserved rights were supposed to keep him from having to haul potatoes for piece pay. If the settlement was to compensate, why had they not received anything after the damages? What was taking so long? ${ }^{244}$

Charley had written Neuberger and Senator Warren G. Magnuson about the status of the settlement funds on March 11, 1957, the day after the dam flooded Celilo. Magnuson and Neuberger discovered the BIA had "taken the position that the money paid to the Yakima Tribe under the Dalles Dam settlement is a capital gain.” In other words, the BIA viewed the funds as an exception to regular income or per capita payments. Thus, the Internal Revenue Service would tax the funds for capital gains, at a much higher rate of taxation. Further, the BIA held, "The Dalles Dam money constitutes a payment by the Federal Government for the loss sustained by the Yakima Tribe as a whole, as distinguished from losses sustained by individual members." Not only would the Internal Revenue Service tax the money at a much higher rate, but the tax would be assessed against the tribe before it was distributed, making a greater amount of the fifteen million taxed away before it ever got to tribal members. ${ }^{245}$

\footnotetext{
244 Charley to James, July 15, 1957, folder 42, box 1, JJP.

245 Charley to Warren Magnuson, March 11, 1957, folder 5, box 13, RNP; Charley to Neuberger, March 11, 1957, folder 5, box 13, RNP; Thomas M. Reid to Melvin Goudy, April 18, 1957, folder 5, box 13, RNP;
} 
The news infuriated Charley, who, with sound legal logic, questioned the federal government's authority to tax any tribal settlement. In general, Congress did not tax per capita payments to Indian tribes, as Congress long considered these annuities - moneys often promised in treaties and settlements, which through nation-to-nation negotiation, were exempt from taxation. While it took years, Neuberger worked to get the IRS to compromise by assessing the tax after distribution to each individual. Finally, in May of 1959, Neuberger shepherded a bill through committee and to the Senate that completely exempted federal taxes on any of the settlement funds. While Neuberger helped free the final settlement from taxation, BIA administrators still held their grip on the funds. In the end, Neuberger and the BIA procedures reinforced a form of bureaucratic paternalism, ironically at a time when federal policy aimed to cull it. ${ }^{246}$

Indeed, BIA paternalism had Charley in a paradoxical situation. Without the money, he continued to struggle to find a replacement income. However, if he accepted funds, he would affirm the BIA's authority to tell the tribe how to manage its own governance. At the tribal level, Yakama Chairman Alex Saluskin hoped to use the dam's settlement funds to build up tribal programs and to create a tribally-controlled timber operation to uplift the reservation—similar to what the leaders on the Warm Springs Reservation were doing. "It is my firm belief that the Indians can progress rapidly and

246 Roger Ernst to Richard M. Nixon, May 7, 1959, folder 6-7, box 12, RNP; Draft bill and statement of Richard Neuberger before the United States Senate, May 26' 1959, folder 6 - 7, box 12, RNP; "Indian Bill Makes Step," Oregonian, May 27, 1959, p. 8. 
take their place in society.... [If] the remaining resources could be held intact for the members who want to remain on the Reservation as long as they want to stay," wrote Chairman Saluskin. However, Saluskin was not the only leader with economic development ideas; Charley had his own. ${ }^{247}$

\section{Charley's Post-Dam Economic Proposals}

Just months after the dam had altered the course of his livelihood, Charley was hard at work planning post-dam economic development ideas — huckleberry processing, tribal timber harvests, and educational programs. However, because he was no longer on the Tribal Council, he found it difficult to get his own tribe and the BIA to approve any of these enterprises. Instead, Charley went directly to the state and federal bureaucrats. He challenged the position that settlement was for a loss of tribal resources and asserted that he be compensated individually to start his own businesses. Although he failed, his work exposes the shortcomings in state and federal management and shows how one individual aimed to address these shortcomings by presenting solutions for his community. As before, Charley had powerful solutions, but few were listening.

The first plan involved a Native huckleberry canning operation. In 1957, a few months after Charley had returned to the river to fish, he was suffering from a cold, a sore leg, and, likely, depression. Charley's doctor ordered him not to go to the river any more and rest up, but not visiting the river was a prescription that only made things worse for

247 Alex Saluskin to James, Sept. 16, 1957, Folder 46, Box 1, JJP. 
his emotional health. Instead, he took an extra week in the mountains before the annual Huckleberry Feast to help clear his mind. While he barely had enough gas money to make it up to Meadow Creek in the Gifford Pinchot National Forest, he managed to pull the cash together. ${ }^{248}$ Arriving a week before the feast, he was alarmed to discover, "the white people are already there with their tin cans...they do not realize how much they are hurting the growth of the huckleberries when they start picking early." He noted, "we have strict laws, no huckleberries until after the feast." Once again, non-natives had ignored well-perfected regulatory customs to the detriment of the resource. It seemed anywhere he went, non-natives were ignorant to Indian rights as they disrespected deeply rooted Indigenous ecological knowledge. ${ }^{249}$

Charley was inspired to use a commercial venture to protect the huckleberry fields. After he had returned from the feast, Charley hammered out a letter to Richard Neuberger and "all public officials and bureaus chiefs." Alarmed by the incident in the huckleberry fields, and trouble in nearly every facet of his life, Charley declared, "OUR SECURITY, HERITAGE, AND CULTURE IS NOW AT STAKE.” On his own, Charley

\footnotetext{
248 Meadow Creek is a very significant Indian camp located in the Gifford Pinchot National Forest. Plateau peoples have utilized the camp and Sawtooth Berry Fields as a premiere huckleberry gathering area for thousands of years. However, in the early twentieth century non-native pickers and sheep grazers overran the alpine meadows and tensions between indigenous communities and non-native users increased. As a result, the U.S. Forest Service and Yakama Nation brokered the 1932 "handshake agreement" designating the camp and fields east of Road 24 for the exclusive use of Indians. For a fuller discussion see, Andrew H. Fisher, "The 1932 Handshake Agreement: Yakama Indian Treaty Rights and Forest Service Policy in the Pacific Northwest," The Western Historical Quarterly 28, no. 2 (1997): 187-217.

249 Charley to James, July 15, 1957, folder 42, box 1, JJP.
} 
began exploring the possibility of using BIA funds to start a tribal commercial huckleberry canning operation. Over the next year, Charley sketched up a label and explored radio advertising for a tribal-run operation that could employ 1,000 people for a few weeks during the harvest. He took quarts of berries that he and his wife picked to a canner, where they were able to sell the product for three dollars a gallon to white tourists. It was minimal cash for a great deal of effort. Commercial huckleberry picking requires lots of time, navigating rough forest terrain, and transportation to processing sites. With some adjustments, he estimated he could employ pickers for about thirty-six dollars per day. While it would be very hard work, over the span of a few weeks, cash like this could dramatically assist a displaced fishing family who had lost their major source of annual income. It would also empower the individual participating tribal members to advance themselves economically and reinforce traditional celebrations and ceremonies. ${ }^{250}$

Jimmie James agreed that the idea was brilliant, but the funds to start such an operation remained out of reach in the BIA account. "Maybe it is just a dream, maybe it would be like all other things; people would let us down," lamented Charley as he outlined the huckleberry proposal to James. He continued, "I am trying...to help all my people better [ourselves] in ways the that Bureau of Indian Affairs failed us

250 Ibid., Charley to James, Jan. 11, 1957, folder 42, box 1, JJP; Charley to James, Aug. 19, 1958, folder 42 , box 1 , JJP. 
miserably."251

Seeing the timber boom of the 1950s benefit many Pacific Northwest communities, Charley hoped to build a tribal timber operation. "We need Indian scientists, Indian Surgeons, Indian Loggers," wrote Charley in a letter to Senator Henry M. Jackson of Washington State. "We must learn to depend on our timber and other resources," Charley continued to the senator. Additionally, he requested $\$ 400,000$ to repair and maintain forest roads on the reservation. Further, he reminded Jackson that many rural timber towns received federal assistance to extract their timber. "Our white neighbors are given the needed help with federal funds...this money should be appropriated direct to the Yakima Indian Agency," noted Charley and he asked for a similar program..$^{252}$

Indeed, the Yakama Reservation's timber reserves were extensive, and the tribe had only initiated a few timber sales over the years. Testifying at a special Tribal Council meeting Charley reminded council members that past timber sales had helped younger Yakama families "better themselves.... there is a need for an increase on our timber per capita payments." He continued: "[I]n this atomic age, many of our people have a stove.... more per capita timber payments can help with a home and other appliances necessary for better living." As many communities benefitted from the timber boom of

\footnotetext{
251 Ibid.

252 Charley to Henry M. Jackson, Feb 14, 1958, folder 43 box 1, JJP.
} 
the 1950s, Charley felt Congress was leaving the Yakama out of this burgeoning industry. 253

There was plenty of local demand for tribal timber, though. One of his more innovative ideas involved supplying Yakima Valley hop farmers with pine poles. Reading about hop farmers calling for ten thousand hop poles Charley noted, "if my Indian people would band together we could easily cut that many before winter is over." Poor-quality roads could not access the high-country in the winter and remained one significant reason the tribe had been unable to authorize more timber sales in the past. The roads were so rough that Charley could only navigate his one-ton flatbed truck up to get a load of firewood in the best dry weather; navigating a log truck up these roads was out of the question. Charley often commented on the condition of reservation roads as he made trips to cut firewood to heat his home. Numerous times, he dreamt up ideas for Indian run mills and timber enterprises, but each time insufficient road infrastructure and a lack of funds thwarted the plans.

Charley's continued emphasis on timber and huckleberries points to his embrace of new technologies in the changing world - technologies that he understood and felt ready to use but were unavailable to him on the reservation. These post-dam economic development plans were forward-looking and aimed to address a real need for

253 Charley to Yakama Tribal Council, March 2, 1958, folder 43, box 1, JJP; for a narrative of the Pacific Northwest timber boom of the 1950s see Robbins, Landscapes of Conflict. 
replacement income. Further, they also suggested how he viewed resources like timber and berries, which unlike fisheries, he described as a tribal commons. In his mind, per capita payments were fine for industrial forest resources, which required common funds for roads and infrastructure. Fishing stations were clearly different. Fishing stations had long been individual properties, which required investments of time, maintenance, and personal resources. ${ }^{254}$

Educational opportunities for Yakama children were also a major concern for Charley. Charley demanded that Congress appropriate the federal funds for the reservation school enumerated in article five of the 1855 treaty, which "has not, as of yet, been fulfilled." With curtailed access to resources, proper education was important if his children were to cope and survive economically in this new environment. Writing to Mrs. Zelma Reeves Morrison, the president of the board of trustees for Eastern Washington State University and a state delegate for the Democratic Party, Charley used the recent Sputnik controversy to demand better education for reservation children. Reading comparative studies of Russian and American education "proved useful in pointing out weak spots in the American educational program - weaknesses which are in need of remedy if we are to build a strong educational foundation for a future generation," wrote Charley. In these studies, Charley noted that Indian education was absent. Despite the promises for education in over one hundred years of federal policy, "we have not a

254 Charley to James, Dec. 27, 1962, folder 43, box 1, JJP. 
Yakima Indian whom as entered West Point, or... a professional, technical, research scientist, doctor, surgeon.... You know, we should," Charley wrote to Morrison. Pointing out the deficiency, Charley framed the lack of American Indian education as a weakness that undermined U.S. national security. Charley argued, "Indian people would make just as good a professional as anyone from any class or race of human being." Positioning Native education as a priority in fighting communism was in keeping with the strategies of other Native leaders - indeed, it tarnished the nation in the global community and exposed a flaw which communism could exploit. While political rhetoric presented Charley the opportunity for his letter, his overall point, that the Yakama still did not have its own professionals, transcended Sputnik politics. At the same time, his application of the dominant society's terms was nothing new; Native Americans had been doing this since the time of contact. Charley's outline of Native education in terms of U.S. patriotism fits into what historian Paul C. Rosier calls a “hybrid patriotism.” Evident after World War Two, American Indians’ pluralistic national ideology, or hybrid patriotism, "drew upon, rather than destroyed their values." Charley realized that without traditional resources, Yakama children, including his own, 
would need to find new ways to earn a living. This was a national security issue, he argued, for the Yakama and United States. ${ }^{255}$

\section{Contesting the Settlement in Court}

In the midst of planning post-dam economic development plans, Charley joined several other Native fishing families in seeking an injunction to stop the Yakama Nation's per capita settlement, because he felt it unjustly compensated him. The Dalles Dam affected Charley's family fishing stations and it upset him that the United States government had not compensated him adequately. Working with attorney Fredrick Paul, a noted Native American law attorney who later designed the Alaska Native Claims Settlement Act, Charley joined Ambrose and Minnie Whitefoot, Ida White, Sally George, Walter Isaac, and Taylor Abraham in a suit for personal damages, loss of private property, and permanent business income from The Dalles Dam. From the very beginning, they planned to take their case to the U.S. Court of Claims. At the same time, the group also filed a formal complaint with the U.S. Department of Justice and requested an injunction to stop the John Day Dam construction. ${ }^{256}$

\footnotetext{
255 Charley to Mrs. Zelma Reeves Morrison, July 15, 1958, folder 42, box 1, JJP; A brief bio of Morrison appears in Mari J. Matsuda, Called from Within: Early Women Lawyers of Hawai 'i (University of Hawaii Press, 1992), 191-93; Rosier, Serving Their Country, 1-11.

256 Charley to Fredrick Paul, April 8, 1958, folder 43, box 1, JJP; Paul to Charley, Dec. 26, 1958, folder 43, box 1, JJP; Paul to James, Jan. 28, 1958, folder 27, box 1, JJP; Carole Beers, "Fredrick Paul, Attorney for Alaska Natives, Was A Fighter" Seattle Times, May 11, 1994, accessed Aug. 31, 2016 from: http://community.seattletimes.nwsource.com/archive/?date=19940511\&slug=1909888.
} 
While many families contributed to the case, Attorney Paul intentionally narrowed the case to test the personal claims of Ambrose and Minnie Whitefoot. Paul used Ambrose Whitefoot and Minnie Whitefoot v. United States to challenge the per capita settlement and to clarify that the Whitefoots' claim was individual and not a part of a tribal commons. In the initial finding of fact for the case, Paul worked closely with Jimmie James. "You know that some of the fishermen are now finding it very difficult to adjust their lives to the fact that the dam has ousted them from their family inheritance," wrote Paul to James. Noting his lack of experience with mid-Columbia River Natives, Paul asked James to pull together ethnographic sources. "Can you refer me to any literature describing their system of ownership," he asked James. However, James, a selfdescribed expert, had little to offer, suggesting only that Paul consult Ruth Underhill's Indians of the Pacific Northwest, a standard survey text of the time. In turn, Paul consulted an extensive list of anthropological sources that supported his argument that fishing stations were private property controlled by families, including Edward Sapier's Wishram Texts. The U.S. Court of Claims indicated that these anthropological texts were inadmissible in court, which was curious because many cases had, and have, used ethnographies to establish cultural contexts. ${ }^{257}$

257 Ibid.; Paul to James, Feb. 3, 1958, folder 27 box 1, JJP; Paul, "Draft injunction to halt the John Day Dam" No date, folder 27, box 1, JJP; "Ambrose Whitefoot and Minnie Whitefoot v. United States, 293 F.2d 658 (Ct. Cl. 1961)," Justia Law, accessed January 5, 2017, http://law.justia.com/cases/federal/appellate-courts/F2/293/658/234576/; Ruth Underhill, Indians of the Pacific Northwest (Washington D.C.: Bureau of Indian Affairs, 1944); Sapir, Wishram Texts. 
Unable to use ethnographic sources as evidence, Paul turned to Charley and the other families. Through unrecorded conversations in Paul's Seattle office, Charley and his fellow participants informed Paul of their understanding of family fishing rights. "In ancient times there was no inter-governmental authority governing the fourteen tribes [of the Yakama Nation]. That was an invention of Governor Stevens.... It is an essential element of our case to prove that the tribe had no authority to dispossess a family," clarified Paul as he sent out his talking points to his clients. ${ }^{258}$

The U.S. Court of Claims finally heard the Whitefoot case in 1961. Willie John (Yakama) testified that the 1855 treaty did not establish his personal rights because they existed before the treaty. Paul argued that that the treaty reserved and retained all signatories' pre-existing rights. However, U.S. attorney Perry W. Morton argued the contrary; that the treaty established the rights within the tribe and not in individual Indians. The court ruled that treaty rights only applied to tribes and not to individuals, dismissing the Whitefoots.

The court also held that Ambrose Whitefoot's claim had nothing to do with fishing rights because he was claiming the loss of his cableway, not a fishing station with a fee simple title. ${ }^{259}$ While Ambrose had built the cableway in 1947, he had done so with

\footnotetext{
258 Paul to Charley, Ambrose Whitefoot, E.J. Wilton, and A. Grorud, Nov. 26, 1958, folder 42, box 1, JJP. 259 Black's Law dictionary defines fee simple as, "an absolute or fee simple estate is one in which the owner is entitled to the entire property, with unconditional power of disposition during his life, and descending to his heirs and legal representatives upon his death intestate." See, Henry Campbell Black,
} 
an agreement with ACOE, allowing other Native fishermen to use it to access their stations and sell their catches commercially. Furthermore, the ACOE's Realty Division had minimally compensated the Whitefoots in an individual agreement for the loss of their outhouse and shed flooded by the dam in 1955. Because the United States government held title to the land, the cableway itself did not reflect real property. Further, the court held that Minnie Whitefoot, who had claimed the fishing station as her family's property as a "usual and accustomed" station and the source of the family's personal business income, had no claim against the United States because the matter was squarely in tribal jurisdiction. This was a key distinction that would shape fishing rights policy to this day:

The use of accustomed fishing places, whether on or off the reservation, is a tribal right for adjustment by the tribe and that the fact that certain Indians have been allowed to have sole use of a particular spot by the Tribe gives that individual no property right against the Tribe and does not limit the Tribe's right to collect the damages for obliteration of fishing spots by the dam. ${ }^{260}$

Ironically, the court's decision in Whitefoot v. U.S. stood in direct opposition to termination policy. While reformers of American Indian policy pushed to "free" Native Americans from federal supervision and thereby complete their assimilation into U.S. society as individual tax paying land owners, the U.S. Court of Claims had effectively signaled that Natives could not hold real property and reserved rights at the same time.

Black's Law Dictionary: Second Edition, 2nd edition (Union, N.J: The Lawbook Exchange, Ltd., 1995), 487.

260 "Ambrose Whitefoot and Minnie Whitefoot v. United States, 293 F.2d 658 (Ct. Cl. 1961)"; Fisher, Shadow Tribe, 210-11. 
The Whitefoot case had exposed a weakness in how the federal government interpreted treaty fishing rights - seemingly in direct opposition to U.S. v. Winans (1905)demonstrating that the courts would only recognize treaty rights as a tribal commons. This weakness continued to play a significant role in fishing rights disputes between tribes, individuals, and the states of Washington and Oregon.

Challenging the authority of his own tribe continued to put Charley at odds with his former council members. He continued to fight against the settlement points to the dramatic reshaping of the social-political climate resulting from the dam. For Charley's work on the Whitefoot case, a few members of the General Council suggested that he was organizing a plot to accept termination and undercut tribal fishing rights. This was not the case. Throughout his life, Charley had remained a staunch proponent of individually controlled fishing sites, with tribal oversight. He was willing to sue for individual claims strategy to achieve his overall goal: obtaining lasting compensation for the loss of his ancestral sites and fishing grounds. "White men always use some language so it can be turned around in every shape and form," Charley wrote to James, upset over the contradictions in federal policy and the courts. ${ }^{261}$ Aware of both the Klamath and Colville Tribe's ongoing termination efforts, he understood that pursuing components of termination, like personal property, might ironically help assert both treaty rights and his

261 Charley to James, April 25, 1958, folder 43, box 1, JJP. 
inherited stations. As always, Charley was constructing multiple strategies in his continual game of poker against the state and federal power. ${ }^{262}$

Charley and other river Indians understood nuances in policy and law that the colonial administrators did not, but failed to have effective legal representation. Several important disagreements between Charley and Fredrick Paul point to the depth of Charley's thinking, which Paul did not fully understand. Paul, like most non-natives, continued to view primitive technologies as a requisite for treaty fishing rights. Paul's opinion ignored cases like U.S. v. Seufert that had affirmed the application of new technologies. "We have to get other gear and we are going to go below Bonneville dam... and try [fishing] a few places," wrote Charley. His vow to fish from a motorboat below Bonneville Dam frustrated Paul: "The suggestions that you make are not possible. The business of relocating the Indian fishermen at new and different places is not physically or legally possible," wrote Paul. Disagreeing that any in-lieu site could have the same treaty protections, Paul disregarded U.S. v. Taylor, which clearly established Native easements to cross non-native private property. Regarding any new site, including the in-lieu sites promised after Bonneville, Paul asserted, "the whiteman is not obliged to let an Indian cross his land...in the Bonneville situation...I maintain that their [BIA and

\footnotetext{
${ }^{262}$ Historian Laurie Arnold shows how the Colville used termination policy to regain the northern half of their reservation before ultimately stalling the final termination plan for decades. Arnold, Bartering with the Bones of Their Dead; Susan Hood, "Termination of the Klamath Indian Tribe of Oregon," Ethnohistory 19, no. 4 (1972): 379-92; Matthew Villeneuve, "“The Job Was Big and the Man Doing It Was Still Bigger': The Forgotten Role of Thomas B. Watters in Klamath Termination, 1953-1958," Oregon Historical Quarterly 116, no. 1 (2015): 40-67.
} 
ACOE] promising the impossible is fraudulent." Paul remained opposed to any new fishing site on the river and chastised Charley and James for suggesting otherwise and pressing for consensus, "We Simply cannot have disagreements among us," stated an angry Paul. ${ }^{263}$

The increasing state fisheries regulation by Oregon and Washington remained central to Paul's logic opposing any new site. The government would have to "acquire title to the banks of the river to give Indians the same freedom of utilizing the same they had in their treaty locations," wrote Paul. He continued: "The states of Oregon and Washington are not going to refrain from regulating and licensing Indians in these new locations." Correctly gauging the state's interest in regulating Indians, Paul ignored the fact that the federal government could obtain title to lands through eminent domain and had done so in constructing many of the very dams that had caused this situation in the first place. Further, he assumed that the earlier precedent-setting fishing cases did not apply to new sites, and failed to consider that there were many sites that once been usual and accustomed in the past but were now less frequented. Assuming any site not fished in the 1950s was somehow a new site ignored the millennia of experience and the depth of Native's geographic understanding. As Charley noted, virtually any spot along the river had been fished by an ancestor at some point in the past, especially with the seasonal flux

263 The majority of correspondence to Paul was indirect with Charley working though James and James writing to Paul. For the origin of their correspondence see, Charley to Paul, April 8, 1958, folder 43, box 1, JJP; Charley to James, Nov. 25 1959, folder 43 box 1, JJP; Paul to James, Aug. 7, 1959, folder 27 box 1, JJP. 
of the river's flow, so how could it be a new site? Paul's rigid legal mind and his many cultural misunderstandings led to his eventual falling out with Charley after the dismissal of the Whitefoot case. ${ }^{264}$

\section{Contesting the Future of Fisheries}

All along, Charley recognized Oregon and Washington's desire to regulate Native fishing - especially if it was at in-lieu or replacement sites. From the beginning of his involvement with Paul, Charley had been designing an alternative and remained ready to pivot to a new strategy. Working parallel with the Yakama's lawyer in establishing a tribal gillnet fishermen's union, Charley had begun to reach out to the Oregon Fish Commission as well as his established friend Senator Neuberger to get Natives appointed to citizen commissions. ${ }^{265}$

Instead of fighting state regulation, Charley considered completely rewriting it. With an all-out commercial fishing prohibition upriver from Bonneville and the desire of the states to regulate and license even Native subsistence fishing, Charley tried to join the state commissions. ${ }^{266}$ In particular, James provided crucial letters of support in Charley's nomination to the Oregon State Fish Commission. "Pertaining to representation of

\footnotetext{
264 Ibid.; Paul to James, Feb. 6, 1961, folder 27, box 1, JJP; Paul to James, March 3, 1961, folder 27, box 1, JJP.

265 Charley to Paul, April 8, 1958, folder 43, box 1, JJP; Charley to James, Nov. 25 1959, folder 43 box 1, JJP; M.L. Skaret to James, March 28, 1956, folder 39 box 1, JJP.

266 Charley to James, April 8, 1958, folder 42, box 1, JJP; Charley to James, March 10, 1958, folder 42 box 1, JJP; Charley to Oregon Fish Commission and Washington State Department of Fisheries, March 10, 1958 , folder 42, box 1 , JJP.
} 
Indians on both the Fish and the Game Commissions... your points are well taken," wrote Assistant Oregon State Fisheries Director Robert W. Schoning. He continued, "I have known Wilson for many years and have talked with him while he was fishing at Celilo, have learned a great deal from him, and respect his views about fish.” Schoning proceeded to explain how one was appointed to the commission, by the governor, and then explained the recent commercial closure was because of lower than expected fish escapement over the dam. James then sent a nomination to Governor Mark O. Hatfield, who replied,

The interest of the Indians in fish conservation is very sincerely appreciated. I will be very pleased to keep your recommendation in mind and will give your suggestion very thorough consideration at such time as an appointment is to be made.

However, one year later, Hatfield had shelved Charley's request. James sent a follow-up inquiry to the commission, which elicited a curt reply. "Commissioners are appointed by the Governor for specified terms. This is an executive function, and of course, is not a matter of action for the Fish Commission itself," wrote Assistant Director Schoning. Despite the "consideration" of the director and governor, the State Fish and Game Commission never appointed Wilson Charley or any other Columbia River Indian. Commissioners hailed from all regions of the state. Serving annual terms, some commissioners held their seats for decades and the size of the commission varied from five to seven individuals, all of whom were men. Charley's appointment could have made 
a lasting difference - finally acknowledging the breadth and scope of Indigenous

knowledge and empowering a Native to have a say in decisions that affected many Native fishers. Instead, both states continued their antagonism toward Native fishers. With fewer fish after the dam, unsupportive states made an already tense and difficult time for Natives even worse. ${ }^{267}$

It was not that the Oregon Fish Commission and Washington State Department of Fisheries wanted to stop Native fishing above Bonneville all together, they just wanted to assert state authority and control where and how Natives fished on off-reservation sites. Yet, the states still failed to understand that the arbitrary distinction between subsistence and commercial fishing continued to leave Native fishers suffering. Put simply, left out of economic development, there was no way for River Indians to pay for food and bills without salmon to trade and barter. Moreover, state managers' realization that the dam itself had ultimately exacerbated tensions between the state and Native fishers remained absent. Because the dam was federal, the state fisheries officials appeared to throw their hands up as if there was nothing they could do except stop Indians from fishing.

Forwarding the recent salmon counts over Bonneville, Assistant Director Schoning noted that before The Dalles Dam and closure of all commercial fishing above

\footnotetext{
267 Robert W. Schoning to James, Oct. 3, 1958, folder 26, box 1 , JJP; Governor Mark O. Hatfield to James, March 3, 1959, folder 13, box 1, JJP; Schoning to James, 19 Feb. 1959, folder 26, box 1, JJP; Oregon Department of Fish and Wildlife, "Administrative Overview," June 2010, accessed Sept. 26, 2016 from: http://sos.oregon.gov/archives/Documents/recordsmgmt/sched/overview-fish-wildlife.pdf; For a complete list of commissioners to the Oregon Fish and Game Commission see, Oregon Game Commission, "Oregon Fish and Wildlife Commission History," typescript [in the author's possession].
} 
Bonneville, "commercial fishing by Indians was the same as for other citizens." Charley had long disputed this assertion, and Tulee v. U.S. case had affirmed Charley's position. Schoning remained unclear why the state had any authority "to discuss mutual satisfactory conditions under which Indians could fish.... after the virtual elimination of Indian Fishing above Bonneville." James and Charley pressured Schoning to see if Oregon would begin to regulate Native fishing to conserve the declining salmon runs resulting from the dam. Perhaps Schoning sensed this, because he avoided altogether using the term "conservation" to justify intervention in Native fishing. ${ }^{268}$

However, Washington State Department of Fisheries Director Milo Moore made it clear that conservation was the weapon to regulate Indigenous fishing and define which Natives could do so. Referencing his department's accomplishments in developing a fall run of hatchery Chinook salmon on the Klickitat River, Moore claimed credit for the agreement that allowed Yakama to fish at the spot one mile up from the mouth of the river. 269 "This fishing is done pursuant to an agreement with the Yakimas under regulations of the state," claimed Moore. Yet, the reality was much more complex. Over the years, families on the Klickitat had challenged the authority of the Yakama Nation, the state, and the federal government. As historian Andrew Fisher notes, some of these

268 Ibid.

${ }^{269}$ In reality, this agreement was much more biased toward the state hatchery. In 1949 Wilson Charley received word from the hatchery that Natives would be prohibited from selling any fish caught on the Klickitat including stripped carcasses which many families used to pay for bills, Dupris et. al., The Si 'lailo Way, 303. 
families remained unenrolled in any tribe, while others had enrolled on Yakama, Warm Springs, and Umatilla Reservations. In part, they had done this intentionally to provide each other with routes around the bureaucratic rocks. It is unclear if Moore understood these nuances, but given the fact that he lumped all Native fishers together suggests he did not understand the calculated role identity and tribal affiliation played on the Klickitat. 270

What is more telling about Moore's letter is the interest he took in learning about potential in-lieu or other less frequented sites that his enforcement officers could police. "We are extremely interested in your statement that fishing relocations were promised to the Indians during negotiations [at Bonneville and The Dalles]," Moore told James. "We have never been advised by the federal government of the origin of these promises.... We are interested in obtaining a copy of any contract...can you suggest a source?"271 Conservation remained the best tool to assert his power. Thus, Moore affirmed Charley's fear. Conservation was now the state's doublespeak:

In the interests of conservation we are unable to authorize a gill net fishery in the Columbia River above Bonneville. You will appreciate that such operations could well destroy the Fishery resources of the Columbia River. We are certain the Indians do not desire this result. ${ }^{272}$

\footnotetext{
270 Fisher, Shadow Tribe, 209.

271 There were not in-lieu stations promised at The Dalles, but James was concurrently assisting in the Celilo Village Relocation and he might have intentionally exaggerate this point to test Moore. Ulrich, Empty Nets; Barber, Death of Celilo Falls; Fisher, Shadow Tribe.
}

272 Milo Moore to James, Oct. 21, 1959, folder, 39 box 1, JJP. 
Natives did not desire the destruction of the fishery; they had been fighting two generations to prevent that. However, Moore conveniently ignored that the dam was the culprit to why fish runs were in decline and suggested that conservation measures were antithetical to Native rights and practices. Even before dams, it had been the irrigation diversions, mining, logging, and grazing that had resulted in losses of salmon habitat and the eager sport and commercial non-native fishers that had jeopardized the now painfully finite fishery resources.

In the past, Native fishers opposed each of these non-native developments. Moore had long acknowledged the right of Natives to fish unmolested from state licensing, but only if it were from a scaffold or usual and accustomed site from the treaty period. Conveniently, for Moore, dams had made the river slack water pool of progress where Native scaffolds and dip nets were useless. Realistically, gillnets remained the only way to haul in a catch at scale. While it is true that Natives could use hook and line, that technology was both inefficient in a subsistence/commercial context, even if used in widespread fishing, the states could have regulated Native anglers under the same conservation language. In Moore's view, treaty-fishing rights were frozen in time, rigid, and inadaptable. With the scaffolds of Celilo inundated, conservation gave him the 
authority to ban Indians from gillnetting or any new methods. Worse, his discretion was a seemingly unregulated power to prohibit Natives from fishing. ${ }^{273}$

Moore's letter was a devastating blow for Charley and the few remaining families that were trying to keep fishing on the river. Unwilling to incorporate Native practices in state management, Moore had set an ultimatum; accept his state authority or nothing. Moore and Charley's discordant views on conservation signaled a new direction in Pacific Northwest fishing rights, as the rising power of the state used conservation as the ultimate weapon against Native treaty rights. In a final plea for help, Charley requested that Richard Neuberger intervene or sponsor a bill at the federal level to clarify Native gillnetting as a treaty right. However, James and Charley were both unaware of Neuberger's cancer diagnosis and declining health. Understandably, their main D.C. political ally became preoccupied with his terminal condition, which he succumbed to in March of $1960 .{ }^{274}$

As the 1960s began, Moore's letter and Neuberger's death both marked the end of a chapter in Charley's advocacy, but over the next two decades, Native fishers in Oregon and Washington continued to fight state regulators, taking their treaty rights to court. Already feeling defeated, Charley had lost one of his great political allies.

\section{Depression and Loss}

273 Ibid.; Charley to James, April 8, 1958, folder 42, box 1, JJP; Courtland Smith, Salmon Fishers of the Columbia, (Corvallis: Oregon State University Press, 1980); Dompier, The Fight of the Salmon People. 274 Charley to James, Nov. 25, 1959, folder 43, box 1, JJP; Robbins, Landscapes of Conflict, 246. 
It would be a mistake to conclude that Charley's strategies failed. While many of his strategies looked like dead ends to him, the social climate of the U.S. shifted during the 1960s and 1970s. This period, characterized by civil rights struggles, burgeoning environmental awareness, and a younger generation who questioned conformity, created a situation where Indigenous leaders felt it worth the risk to take treaty-fishing rights to federal court. ${ }^{275}$ Indeed, most histories of Pacific Northwest Fishing Rights center on the Puget Sound "Fish-ins." Made famous by Hollywood actor Marlon Brando, the Native protesters molded their strategy after the lunch counter "sit-ins" of the Student Nonviolent Coordinating Committee in the Deep South. Native and non-natives alike fished in direct protest to Washington State Department of Fisheries regulations and used their arrests to raise public awareness of Natives struggle to exercise their treaty rights. ${ }^{276}$ Yet the bulk of Charley's leadership all occurred decades before these significant protests. As he read about these events, he remained interested but distant.

Charley long expressed his concern that The Dalles Dam had taken away his livelihood and that compensation was finally discussed only after, not before, the sites were flooded. A proponent of the rights of his private property, he still advocated that the tribes needed to regulate and define fishing internally, but he believed that treaty rights

275 For a narrative of this new generation see, Smith, Hippies, Indians, and the Fight for Red Power. 276 Ibid. 
were vested in individuals. Charley continued to fish from Lone Pine for subsistence only and the declining fish runs led to further emotional and economic suffering. 277

The fishing was terribly poor. Charley's loss of income made it harder and harder to make ends meet. Without a strong supply of fish for his family or for trade, he was unable to fulfill his end of supporting the household. In 1962, Charley's wife left him, took their daughter Yevette, and moved with her family on the Warm Springs Reservation. Charley's already deep depression got worse, but he had anticipated the separation. Without his wife's side of the story, a full explanation of the divorce is unclear, but Charley did note that he did not resent her leaving him. In her study of Plateau gender, anthropologist Lillian Ackerman notes that divorce was not uncommon as Plateau culture considered marriages contractual agreements. A man or woman could leave their partner if the other could not hold up their end of the contract - this general explanation might apply to Charley's divorce. Still, it pained Charley. "I am trying to heal the wound that was cut so bad and its [sic] hard to heal right away.... It will be best for me if I stay alone now," he wrote. He continued, "I am only thinking of my little girl, she is the only one that has kept me from feeling sorry for myself." The loss of fishing grounds and the prohibition of gillnetting had serious social, as well as economic, consequences for Charley and his family. It stands as a personal example of how his, and

277 Charley to James, June 5, 1962, folder 43, box 1, JJP; Charley to James, Jan. 1, 1963, folder 43, box 1, JJP. 
many other families, were thrown into deep depression and economic struggle by the dam and state power. ${ }^{278}$

Things kept getting worse. "My wife has been my good luck charm and my right hand," wrote Charley as matters continued to turn worse. Both of his trucks, which he used for wood hauling and farm labor, had mechanical trouble, and he had used one as collateral for repairs for the other. "I am getting deeper in debt now and I really don't know how I am going to get out of it," wrote Charley as he proposed selling his trust land on the reservation. However, many others were in similarly depressed economic times, and because he could only sell his trust land to a tribal member, he had difficulty finding a buyer. "That's like selling a Russian mermaid," Charley joked with James about selling the land. Charley had taken a small job picking squash near Madras and had some time to visit his daughter, but that work had ended. He found work for a few days picking apples and later spent several months picking string beans outside Independence, Oregon. Working the farm fields, he endured racial slurs as farmers mistook him for a Mexican migrant laborer. His aging body, especially his knees, was always a limiting factor in manual farm labor. Charley found it difficult "to work for someone else because they

278 Charley to James, March 6, 1962, folder 43, box 1, JJP; Charley to James, Oct. 16, 1962, folder 42, box 1 , JJP. 
keep looking over your back to see if you are doing the job right. As if I had not done any work before."'279

Even in his worst times, Charley refused to beg and outright refused assistance if it was just because he was Native. Jimmie James offered to lend Charley money on numerous occasions, but Charley refused outright charity. Upset at an offer from an unnamed white woman, Charley noted: "We like to have dressers, Frigidaires, and things like that...her idea is that she wants the indian people to beg for things...we want people to give not only to indian people but to others who are in need. There are many white people that are in need also," stated Charley. He reminded James that charity should be for "the needy people of class" and not just Natives. Exchanges such as these show the depth of Charley's wisdom in distinguishing between the rational for charity—supporting it for those in need and rejecting it when connected to race. ${ }^{280}$

Debts continued to pile up for Charley. After years of trying to settle his father's estate, Charley needed two hundred dollars, a significant amount of money at that time, to file the paperwork and sell his father's property. At an all-time low, he offered to sell his father's prized rodeo buckskin for seven hundred dollars and attached a picture- - but James could not bring himself to do it and loaned Charley the money instead. By 1964,

279 Charley to James, June 6, 1962, folder 43, box 1, JJP; Charley to James April 19, 1963, folder 43 box 1 , JJP; Charley to James Aug. 27, 1963, folder 43, box 1, JJP; Charley to James, Nov. 30, 1963, folder 43 box $1, \mathrm{JJP}$.

280 Charley to James, Aug. 13, 1963, folder 43, box 1, JJP. 
Charley noted, "I can’t do much day labor any more.... I sure feel the pain and I mean PAIN." Now at age 62, he started trying to get Social Security compensation and began to contemplate how to pass the torch. Desperate for money he again tried to sell his home on the Yakama Reservation and moved into his small fishing shed at Lone Pine. ${ }^{281}$

Reading letters and newspapers by candlelight, Charley continued to learn about arrests as Indians fished along the Columbia and Puget Sound. Worried that the future employment opportunities for youth would pull Natives to far away states, Charley was proud to see so many young people participating in the Puget Sound Fish-ins. "I wish the youth would get together and organize and make their own rules and regulations because they are the future responsibility of this wonderful and great country," wrote Charley. Reflecting on his own life as a Columbia River Indian leader, Charley noted, "what happens from now on only the Great Spirit knows.... I have no regrets of the past. I had a good life." Even with all the hardships he had faced, all the losses he had witnessed, and all his innovative strategies that had seemingly failed, he continued, "I am not mad for I love everything. I know someday I will be rewarded for my past actions."282

281 Charley to James Aug. 8, 1962, folder 43 box 1, JJP; Charley to James, April 30, 1964, folder 43, box 1, JJP; Charley to James, July 3, 1964, folder 43 box 1, JJP.

282 Charley to James, Aug. 17, 1963, folder 43, box 1, JJP; Charley to James, Jan. 29, 1964, folder 43, box $1, \mathrm{JJP}$. 


\section{Conclusion}

\section{Tracing Charley's Legacy}

On April 14, 1964, Wilson Charley went fishing at Lone Pine and returned to his home to finalize sale papers for his allotment. He found his home ransacked. Boxes and papers were everywhere. His home was turned upside-down. Several pieces of prized family regalia, including his father's buckskin were gone. Whether they know it or not, the thieves had stolen key symbols of his leadership. His family regalia not only held sentimental value but also symbolized his position in a long line of Indigenous leaders. His typewriter, the device which had allowed him to generate a vast volume of letters to influential politicians, conservation leaders, and land managers, was gone. While he continued to write James over the next year using pencil and paper, Charley struggled to find adequate stationary and even stamps. Without a typewriter, his letters became less and less frequent - fewer and fewer heard his voice. Following the theft of his typewriter, tracing his leadership becomes increasingly difficult.

The letters of Wilson Charley show first-hand how he fought to uphold the protections that his ancestors established in the 1855 treaty. Together, the letters show how one Indigenous man not only dealt with rapid political and ecological changes in the postwar Pacific Northwest, but how he articulated multiple strategies and presented intellectual ideas to non-natives that were pragmatic, rational, and ahead of their time. Innovative strategies, like partnerships with non-native environmental and conservation 
groups, tribal fisheries regulations, archaeological consultation, and ancestral grave protections would take decades before the courts and colonial administrators would embrace them in federal law and policy. A new generation of Native leaders built on Charley's earlier work.

Charley's alternating strategies in using tribal power versus individual Native rights were dependent on the situation, both valid responses for long-term survival. $\mathrm{He}$ understood the political ramifications of Termination and carefully limited his legal battles to individual claims. Even with a poor poker hand (politically speaking), his strategies kept the door open for the tribes to bring forth federal cases on treaty fishingeventually resulting in the Boldt and Belloni decisions, which now establish Natives' right to fifty-percent of the catch. In his early work, fighting state intervention in Native fishing rights and asserting tribal jurisdiction over the archaeological sites of his ancestors, he took a firm stance that the Yakama Nation had regulatory power. At the same time, he understood an assertive tribal government could upset the power of traditional river families, who had owned and regulated these places for generations. Maintaining his personal connections to river families, he continued to fight for fishing rights and compensation that better reflected the loss of his and other fishers' income. While he was willing to play both sides, he understood that non-natives would only recognize the authority of tribal governments. 
The letters also establish culpability in non-native politicians, conservationists, and federal managers dismissal of Charley. Powerful leaders knew of the alternatives Charley presented, ideas that they willingly ignored or dismissed. Charley's letters completely challenge the often-told justification that engineers and planners did not know the consequences of building the dam. Even the President of the United States knew and still ignored Charley's plea to intervene. Final judgment for these individuals must be on their own terms and contexts, but the evidence in Charley's letters establishes a degree of culpability.

Charley mailed his final letter to James James on October 6, 1965. In the coming years, James fell into declining health. He died on January 22, 1969. Buried overlooking the Columbia River at Cascade Locks, James' friend Alice Seitzinger packaged all his incoming and outgoing letters and donated them to the University of Oregon Special Collections in $1969 .{ }^{283}$ Charley, suffering from depression, continued to struggle for years to "make a few dollars a day" picking apples, beans, and hauling potatoes. Perhaps he helped strategize fish-ins, or legal strategy, but the evidence is scarce. Charley died October 6, 1983, and although his work set the stage for tribally centered fisheries programs, it is unclear if he knew of the formation of the Columbia River Intertribal Fish Commission and the significant Boldt and Belloni decisions.

\footnotetext{
283 I am grateful to Linda Long at University of Oregon Archives and Special Collections for finding this information in the donor file for the James James Papers.
} 
Proud of his ancestors for securing treaty fishing rights, Charley always found fishing his family station brought him independence, peace, and prosperity. In his final letter to James, Charley wrote, "I wish I was not crippled up like I am. I sure wish I could work for myself, just like I use to do 20 or 30 years ago.” Perhaps unaware it would be his last letter to James, Charley chillingly lamented, "oh well, those days are gone forever."284

\section{Fast-forward}

Although Charley's letters ended, the struggle for fishing rights continued. While Charley's letters end in a somber tone, Native Americans struggle for fishing rights was ramping up for more intense legal battles. In many respects, Charley’s visions became reality, and his contemporary successors show Indigenous leaders remain at the forefront of environmental and social justice on the river. Throughout the 1960s and 1970s, Natives in Oregon and Washington State continued to fish in violation of State conservation restrictions. The subsequent vicious and violent episodes of fishing rights battles in the Puget Sound and Columbia River would come to attract international attention, Hollywood celebrities, and a pan-Indian support network. These fishing rights

284 Charley to James, Nov. 22, 1962, folder 43, box 1, JJP; Charley to James, April 14, 1964, folder 43, box 1, JJP; Charley to James, Oct. 6, 1965, folder 43, box 1, JJP. Jimmie James died January 22, 1969 and is buried in Cascade Locks. See, Red DeMars, "Jimmie James: The Untold Story," Screenings, Dec. 1997, p. 2. 
battles featured non-native allies and intertribal alliances and differed from Charley's work by applying tactics utilized by the black freedom struggle. ${ }^{285}$

Eventually, the fish-ins and arrests led to political pressure and legal action. In 1968, fourteen Yakama tribal members filed suit against McKee Smith and the entire Oregon Fish Commission, including Robert Schoning, whom Charley had written frequently. Filing as individuals, the fourteen plaintiffs in Sohappy v. Smith claimed state conservation laws violated their treaty-protected rights to fish at usual and accustomed stations. A parallel case, U.S. v. Oregon, represented the four Columbia River treaty tribes claiming the same grievance but under tribal jurisdiction. Seeing commonality between the two cases, but not the difference in individual virus tribal authority, Judge Robert Belloni combined the cases and handed down a favorable decision for Native fishers in 1969. Affirming that Natives were entitled to a "fair share" of the fish runs, the decision limited state power to regulate tribes. In 1974, Federal District Judge George Boldt clarified Belloni's "fair share" ruling asserting that tribes and the states were entitled to a fifty-fifty percent allocation of the fish runs. In appeals for several more years, these two cases finally recognized tribe's (not individual Natives') right to regulate tribal members and exempt them from state law.

285 Wilkinson, Blood Struggle; Donald L. Parman, "Inconstant Advocacy: The Erosion of Indian Fishing Rights in the Pacific Northwest, 1933-1956," Pacific Historical Review 53, no. 2 (May 1, 1984): 163-89; Shreve, "From Time Immemorial"; Smith, Hippies, Indians, and the Fight for Red Power; Wilkinson et. al., Messages from Franks Landing. 
Despite the victory, both cases continued to reinforce the idea that treaty-fishing rights were tribal and not individual rights. Still, the rulings set the groundwork for the Yakama, Warm Springs, Umatilla, and Nez Perce tribes to establish their own independent regulatory authority called the Columbia River Inter Tribal Fish Commission (CRITFC). Working towards similar goals, the well-documented fishing rights battles of the 1960s, and the precedent setting cases of the 1970s and 1980s were built upon the lesser-known tactics and strategies employed by Charley and his contemporaries of the 1930s, 1940s, and 1950s. ${ }^{286}$

Today, CRITFC tribal enforcement officers patrol the river and the commission sets locally and seasonally specific parameters for tribal members to fish each run. In 2014, Kim Brigham, a member of the Confederated Tribes of the Umatilla Indian Reservation, opened a retail fish market in Cascade Locks that helps fishing families sell their catches to individual consumers as well as commercial fish buyers-finally fulfilling Charley's dream to have a Native-run refrigeration house. Not only do tribal enforcement officers patrol the river checking on who is fishing and how people are doing it, but they also protect sacred and sensitive archaeological sites from looters and

\footnotetext{
286 “Sohappy v. Smith, 302 F. Supp. 899 - Dist. Court, D. Oregon 1969 - Google Scholar," accessed January 5, 2017, https://casetext.com/case/sohappy-v-smith-2; “UNITED STATES v. WASHINGTON," accessed January 5, 2017, http://caselaw.findlaw.com/us-9th-circuit/1493316.html; Fisher, Shadow Tribe, 222-29; Timothy Weaver, "Litigation and Negotiation: The History of Salmon in the Columbia River Basin," Ecology Law Quarterly 24, no. 4 (September 1, 1997): 677; Jovana J. Brown, "Treaty Rights: Twenty Years after the Boldt Decision," Wicazo Sa Review, 10, no. 2 (Autumn 1994): 116; Pevar, The Rights of Indians and Tribes, 185-201.
} 
damage by other industrial users. In 1997, a series of programmatic agreements between the federally recognized tribes of the Columbia River Basin and the Bonneville Power Administration created eight inter-tribal working groups, which oversee a multi-milliondollar budget to mitigate the loss of habitat, damage to archaeological sites, and threats to cultural practices impacted by all thirty-one federal dams in the basin. While these working groups will not resolve the hurt from the dams' completion, for the first time, they both recognize the sovereignty of the tribes and mandate their presence at the table in determining how the Bonneville Power Administration manages the river. Currently, the operations of the entire Federal Columbia River Power System is under review as agencies draft a new environmental impact statement. In this process, tribal leaders have a guaranteed seat at the table-fulfilling one more of Charley's dreams. ${ }^{287}$

While Charley's contemporaries fulfilled his dreams, Native leaders continue to maintain a watchful eye to environmental threats on the river. On June 3, 2016, a ninetyseven-car train carrying Bakken crude oil from North Dakota derailed and exploded in Mosier, Oregon, leaking the contents of four cars into the Columbia River. Immediately, Native voices were front and center to the media coverage. Responding hours after the spill, Paul Lumley, the Executive Director of the Columbia River Intertribal Fish Commission (CRIFC) issued a statement, "For years, the tribes have been a part of the

287 Elizabeth C. Terhaar, "Tribal Fishing Traditions," River Currents, no. 1. 2016, p. 14 - 15; Ben Goldfarb, "The Great Salmon Compromise," The High Country News, Dec. 8, 2014, accessed Oct. 13, 2016 from: http://www.hcn.org/issues/46.21/the-great-salmon-compromise; Federal Columbia Power System Cultural Resource Program, Summary of Accomplishments: Fiscal Years 2010 - 2014, Dec. 2015. 
chorus of voices telling of the danger and risks posed by fossil fuel transportation through the Columbia River Gorge." Indeed, since November 2014, six trains, each carrying up to three millions gallons of crude oil, passes through the Columbia River Gorge every day. Since 2013, railcar oil spills have gone up nationally with the increase in shipments. These shipments through the gorge are alarming to environmental advocates, and especially Native fishing families. ${ }^{288}$

Just a few days after the Mosier oil spill, JoDe Goudy, Yakama Nation Tribal Council Chairmen stood behind a podium dressed in full regalia and called for a "zero tolerance" policy to end all shipments of fossil fuel through the gorge. Impassioned, he argued, "the reality of the small percentage who reap the economic gain of those endeavors is not worth the long-term consequence that could potentially be endured by you and I." Further, he reminded the press that the spill coincided with the 161 st anniversary of the Yakama Nation's treaty of 1855. "Our fishing rights are under assault from negligent industry who are more concerned about their bottom line than protecting our lands and waters," Chairman Goudy declared. A full contingent of national and international press clicked shutters and recorded sound bites. Goudy was only one of many leaders at the press conference. Leaders from other Northwest tribes spoke, as well

\footnotetext{
288 Rob Davis, "3 Oil Trains Weekly Make Portland to Clatskanie the Most Heavily Traveled Route in Oregon," OregonLive.Com, July 3, 2014, accessed Dec. 4, 2016 from:www.oregonlive.com/environment/index.ssf/2014/07/3_oil_trains_weekly_make_portl.html; "Mosier Train Derailment and Oil Spill" The Dipnetter: News of the River From the Columbia Inter-Tribal Fish Commission, July 2016;
} 
as representatives from CRITFC. Columbia Riverkeeper, an environmental watch group, the city of Mosier, and even Robert Kennedy Jr. joined in opposing future oil shipments in the gorge. Native leaders and environmental advocacy groups had banded together to protect the river, the press was listening, and politicians at the state and federal level claimed they would act. Time will tell. 289

The entire episode raises parallels to Charley's work—especially his article in Man's Life. At the same time, the press coverage stands in stark contrast to the numerous times Charley tried to build cross-cultural coalitions. In Charley's time, non-native conservationists and proto-environmentalists did not align with tribes. Today, many environmental groups on the Columbia River not only acknowledge Indigenous authority in contemporary environmental stewardship, but also give tribes preference in developing policy, designing research, and leading enforcement.

As Charley predicted, despite the proliferation of dams and increased threats to the ecological health of the river, the salmon are not all gone. Weeks after the oil spill the Washington Department of Fish and Wildlife issued its 2016 count of Columbia River Sockeye, ranking the annual returns the fifth largest since 1938. A large part of the

\footnotetext{
${ }^{289}$ Everton Bailey Jr., "Mosier Oil Train Derailment: 65 Truckloads of Crude Oil Cleared, 25 More to Go," OregonLive.com, accessed September 28, 2016, http://www.oregonlive.com/pacific-northwestnews/index.ssf/2016/06/mosier_oil_train_derailment_30.html; Patrick Mulvihill, "Tribes Call for Block on Fuel Trains," Hood River News, June 10, 2016, http://www.hoodrivernews.com/news/2016/jun/10/tribescall-block-fuel-trains/; Dompier, The Fight of the Salmon People; James MacPherson, "Yakama Nation Leaders Join National Tribal Solidarity at Pipeline Protest in N. Dakota," KIMA News, August 30, 2016, http://kimatv.com/news/local/yakama-nation-leaders-join-national-tribal-solidarity-at-pipeline-protest-in-ndakota.
} 
increase in salmon populations has to do with the habitat restoration, policy lobbying, and hatchery programs of the Columbia River tribes, and by fisheries regulations established and enforced by CRITFC. Founded in 1983, Yakama Nation Fisheries amalgamates scientific expertise and traditional cultural practices to manage restoration, protection, and advocate for basin-wide collaborative management of fish populations. Managing over one hundred innovative projects with various partners, the Yakama Nation Fisheries employs two hundred people in an ongoing effort for ecological restoration. ${ }^{290}$

On so many fronts, there are meaningful reforms in the process. At the same time, environmental threats continue to jeopardize Native concerns while history demonstrates the difficult struggles and policy reversals. In a recent optimistic development, CRITFC endorsed Senate Bill 3222, the Columbia River In-Lieu and Treaty Fishing Access Sites Improvement Act. The bill addresses unfulfilled agreements from The Dalles and Bonneville Dams by allocating funds to improve the sanitation, safety conditions, and improves tribal member's access to in-lieu and traditional fishing sites. These are but a few projects that Charley and generations of Indigenous leaders have been fighting one hundred fifty years to remedy. Through persistence and over a century of leadership,

290 “Columbia River Sockeye Salmon Return Is Fifth Largest since 1938," The Seattle Times, July 18, 2016, http://www.seattletimes.com/sports/columbia-river-sockeye-return-is-fifth-largest-dating-back-to1938/; "Chinook Season: Salmon Restorations Fuel Large Tribal Industry," Hood River News, accessed September 28, 2016, http://www.hoodrivernews.com/news/2016/sep/03/chinook-season-salmonrestorations-fuel-large-trib/; Laura Gephart, "Yakama Nation's Willy Dick Creek Bariar Removal and Floodplain Enhancement Project, The Dipnetter: News of the River From the Columbia Inter-Tribal Fish Commission, April 2015; Yakama Nation Fisheries, Yakama Nation Fisheries Program Status and Trends Report (2015) accessed Oct. 13, 2016 from: http://host119.yakama.com/. 
federal and state administrators are finally recognizing Indigenous peoples' very active management role on the river. Wilson Charley's leadership set the stage for all of these changes. His story reminds us that Native persistence, ingenuity, and leadership will remain "as long as the mighty Columbia River flows."291

291 Paul Lumley, "Testimony of Columbia River Inter-Tribal Fish Commission Regarding S.3222 the Columbia River In-Lieu and Treaty Fishing Access Sites Improvement Act, Before the Senate Committee on Indian Affairs, United States Senate" (Columbia River Inter-Tribal Fish Commission, September 14, 2016),

http://www.indian.senate.gov/sites/default/files/upload/images/9.14.16\%20Paul\%20Lumley\%20Testimony .pdf. 


\section{Bibliography}

\section{Archival Sources}

Celilo Falls Indian Relocation Project Records, Mss 2678, Oregon Historical Society Research Library, Portland, Oregon.

General Subject Correspondence 1939 - 1953, Portland Area Office, Records of the Bureau of Indian Affairs, RG 75, National Archives and Records Administration-Pacific Alaska Region, Seattle, Washington.

James James Papers, AX 553, Special Collections \& University Archives, University of Oregon Libraries, Eugene, Oregon.

Mid-Columbia Fisheries Association, "The Wealth of the River: A Presentation of Fact Concerning the Salmon Industry at and Near Celilo Falls on the Upper Columbia River...” Sep. 1945, Oregon Historical Society Research Library, Portland, Oregon.

National Hells Canyon Association, Washington, D.C. Office records, Bx 042, Special Collections \& University Archives, University of Oregon Libraries, Eugene, Oregon.

Richard Neuberger Papers, Ax 078, Special Collections \& University Archives, University of Oregon Libraries, Eugene, Oregon.

\section{Government Reports}

Darwin, L.H. Thirtieth and Thirty-First Annual Reports of the State Fish Commissioner. State Fish Commissioner of State of Washington, 1921.

Federal Columbia Power System Cultural Resource Program, Summary of Accomplishments: Fiscal Years 2010 - 2014, Dec. 2015.

House Journal of the State of Washington. Washington State Printer, 1920.

Lumley, Paul. "Testimony of Columbia River Inter-Tribal Fish Commission Regarding S.3222 the Columbia River In-Lieu and Treaty Fishing Access Sites Improvement Act." September 14, 2016. http://www.indian.senate.gov/sites/default/files/upload/images/9.14.16\%20Paul\% 20Lumley\%20Testimony.pdf. 
Outdoor Recreation Resources Commission: Hearing Before the Committee on Interior and Insular Affairs, United States Senate, Eighty-Fifth Congress, First Session, on S. 846, a Bill for the Establishment of a National Outdoor Recreation Resources Review Commission. May 15, 1957. U.S. Government Printing Office, 1957.

“Rivers, Harbors, and Flood Control Act of 1950." Congressional Quarterly Almanac. Accessed December 4, 2016. https://library.cqpress.com/cqalmanac/document.php?id=cqal50-1375741.

Schoning, Robert W., Theodore R. Merrell, and Donald R. Johnson. "The Indian Dip Net Fishery at Celilo Falls on the Columbia River." Portland: Oregon Fish Commission, 1951.

Swindell, Edward G. Report on Source, Nature and Extent of the Fishing, Hunting and Miscellaneous Related Rights of Certain Indian Tribes in Washington and Oregon Together with Affidavits Showing Locations of A Number of Usual and Accustomed Fishing Grounds and Stations. Los Angeles: United States Department of the Interior, Office of Indian Affairs, 1942.

U.S. Army Corps of Engineers, "Summary Report on The Indian Fishery at Celilo Falls and Vicinity, Columbia River 1947 - 1954," 1955, Stream Net Library, accessed January 5, 2017, http://docs.streamnetlibrary.org/SummRepCelilo1947-54.pdf.

Yakima Tribal Council. The Yakimas: Treaty Centennial, 1855 - 1955. Yakima, WA: Republic Press, 1955.

Oregon Department of Fish and Wildlife, "Administrative Overview," June 2010, accessed Sept. 26, 2016 from:

http://sos.oregon.gov/archives/Documents/recordsmgmt/sched/overview-fishwildlife.pdf.

\section{Court Cases}

"Ambrose Whitefoot and Minnie Whitefoot v. United States, 293 F.2d 658 (Ct. Cl. 1961)." Justia Law. Accessed January 5, 2017. http://law.justia.com/cases/federal/appellate-courts/F2/293/658/234576

“Sohappy v. Smith, 302 F. Supp. 899 - Dist. Court, D. Oregon 1969.” Casetext. Accessed January. 5, 2017. https://casetext.com/case/sohappy-v-smith-2

“Tulee v. Washington 315 U.S. 681 (1942).” Justia Law. Accessed January 5, 2017 https://supreme.justia.com/cases/federal/us/315/681/case.html. 
"United States v. Taylor, 13 P. 333 (Wash. Terr. 1887)" Public Resource.Org. Accessed January 5, 2017

http://courts.mrsc.org/territoryreports/003TerritoryReport/003TerritoryR.

“United States v. Washington, 506 F. Supp 187 (W.D. Wash. 1980)." Justia Law. Accessed January 5, 2017. http://law.justia.com/cases/federal/districtcourts/FSupp/506/187/1653945/

“United States v. Winans, 198 U.S. 317 (1905).” Justia Law. Accessed January 5, 2017. https://supreme.justia.com/cases/federal/us/198/371/case.html.

"U.S. ex. rel. Sam Williams v. Seufert Brothers, 233 F. 579 (1916)." Public

Resource.Org. Accessed January 5, 2017.

https://law.resource.org/pub/us/case/ca9/briefs/govuscourtsca9briefs1126/gov.usc ourts.ca9.03078.b.01.pdf.

"State v. Towessnute 89 Wash. 478, 154 Pac. 805 (1916)" Public Resource.Org.

Accessed January 5, 2017.

http://courts.mrsc.org/washreports/089WashReport/089WashReport0478.htm.

\section{Newspapers and Other Media}

Hood River News

High Country News

Field and Stream

Life Magazine

Nature Magazine

The Dalles Chronicle

The Oregonian

The Seattle Times

Spokane Chronicle

Spokane Daily Review

Indians at Work: A News Sheet for Indians and the Indian Service

University of Oregon Media Channel. "Echo of Water Against Rocks." Accessed

September 7, 2016. http://media.uoregon.edu/channel/archives/88. 


\section{Articles and Anthology Chapters}

Allen, Cain. "Replacing Salmon: Columbia River Indian Fishing Rights and the Geography of Fisheries Mitigation." Oregon Historical Quarterly 104, no. 2 (July 1, 2003): 196-227.

Axtell, James. "Ethnohistory: An Historian's Viewpoint.” Ethnohistory 26, no. 1 (1979): $1-13$.

Barber, Katrine, and Andrew Fisher eds. "Remembering Celilo Falls (special issue)." Oregon Historical Quarterly, 108, no. 4 (Winter 2007) 520 - 730.

Blackhawk, Ned. "Currents in North American Indian Historiography." The Western Historical Quarterly 42, no. 3 (October 2011): 319-24.

Brown, Jovana J. “Treaty Rights: Twenty Years after the Boldt Decision.” Wicazo Sa Review, 10, no. 2 (Autumn 1994): 1-16.

Butler, Virginia L. "Relic Hunting, Archaeology, and Loss of Native American Heritage at the Dalles." Oregon Historical Quarterly 108, no. 4 (December 1, 2007): 624 43.

_. "Natural Versus Cultural Salmonid Remains: Origin of The Dalles Roadcut Bones, Columbia River, Oregon, U.S.A.” Journal of Archaeological Science 20, no. 1 (January 1993): 1- 24.

_ the Pacific Northwest of North America: A Zooarchaeological Review." Journal of World Prehistory 18, no. 4 (December 1, 2004): 327-405.

— North America.” Quaternary Research 62, no. 1 (July 2004): 1-8.

Campbell, Sarah, and Virginia Butler. "Archaeological Evidence for Resilience of Pacific Northwest Salmon Populations and the Socioecological System Over the Last 7,500 Years." Ecology and Society 15, no. 1 (2010).

Cressman, Luther S., David L. Cole, Wilbur A. Davis, Thomas M. Newman, and Daniel J. Scheans. "Cultural Sequences at the Dalles, Oregon: A Contribution to Pacific Northwest Prehistory," Transactions of the American Philosophical Society, New Series, 50, no. 10 (January 1, 1960): 1-108.

DeMallie, Raymond J. “"These Have No Ears': Narrative and the Ethnohistorical Method." Ethnohistory 40, no. 4 (October 1, 1993): 515-38. 
DeVoto, Bernard "Conservation: Down and On the Way Out," republished in, Patricia Nelson Limerick, and Douglas Brinkley eds., The Western Paradox: A Conservation Reader, (New Haven: Yale University Press, 2001) 153 - 172.

Ewert, Sara E. Dant. "Evolution of an Environmentalist: Senator Frank Church and the Hells Canyon Controversy." Montana: The Magazine of Western History 51, no. 1 (April 1, 2001): 36-51.

Fisher, Andrew H. "The 1932 Handshake Agreement: Yakama Indian Treaty Rights and Forest Service Policy in the Pacific Northwest." The Western Historical Quarterly 28, no. 2 (1997): 187-217.

—. "The Misplaced Mountain: Maps, Memory, and the Yakama Reservation Boundary Dispute" American Indian Culture and Research Journal 36, no.1 (2012): $79-112$.

_. "Tangled Nets: Treaty Rights and Tribal Identities at Celilo Falls," Oregon Historical Quarterly 105, no. 2 (2004): 179 - 211.

Geertz, Clifford. "Deep Play: Notes on the Balinese Cockfight.” Daedalus 101, no. 1 (1972): 1-37.

Johnson, Khalil Anthony, Jr. "The Chinle Dog Shoots: Federal Governance and GrassRoots Politics in Postwar Navajo Country." Pacific Historical Review 83, no. 1 (February 1, 2014): 92-129.

Karlan, Pamela S. "Lightning in the Hand: Indians and Voting Rights." Edited by Laughlin McDonald. The Yale Law Journal 120, no. 6 (2011): 1420-53.

LaLande, Jeff. “Oregon Voices: Oregon's Last Conservative U.S. Senator: Some Light upon the Little-Known Career of Guy Cordon." Oregon Historical Quarterly 110, no. 2 (July 1, 2009): 228-61.

Layman, William. "Riverplaces as Sacred Geography: The Pictographs and Petroglyphs of the Mid-Columbia River." In Great River of the West: Essays on the Columbia River, edited by William Lang and Robert Carriker. University of Washington Press, 2000.

Gradwohl, David M., Joe B. Thompson, Michael J. Perry, "Still Running: A Tribute to Maria Pearson, Yankton Sioux," Journal of the Iowa Archaeological Society 52 no. 1 (2005).

Green, Richard. "Yakama Chief Jobe Charley: His Story in Pictures." Whispering Wind 43, no. 5 (2015): 22. 
Hood, Susan. "Termination of the Klamath Indian Tribe of Oregon." Ethnohistory 19, no. 4 (1972): 379-92.

Hunn, Eugene. "The Utilitarian Factor in Folk Biological Classification.” American Anthropologist 84, no. 4 (December 1, 1982): 830-47.

Lindquist, Wendi A. "Stealing from the Dead: Scientists, Settlers, and Indian Burial Sites in Early-Nineteenth-Century Oregon." Oregon Historical Quarterly 115, no. 3 (2014): 324-43.

Luna, Eileen M. "Mobilizing the Unrepresented: Indian Voting Patterns and the Implications for Tribal Sovereignty." Wicazo Sa Review 15, no. 1 (2000): 91-115.

Mahar, Franklyn D. "The Politics of Power: The Oregon Test for Partnership." The Pacific Northwest Quarterly 65, no. 1 (1974): 29-37.

Miller, Susan A. "Native America Writes Back: The Origin of the Indigenous Paradigm in Historiography." Wicazo Sa Review 23, no. 2 (October 1, 2008): 9-28.

Parman, Donald L. "Inconstant Advocacy: The Erosion of Indian Fishing Rights in the Pacific Northwest, 1933-1956." Pacific Historical Review 53, no. 2 (May 1, 1984): 163-89.

Peterson, Helen L. "American Indian Political Participation." Annals of the American Academy of Political and Social Science, Vol. 311 (May 1957): 116 - 126.

Shreve, Bradley G. "“From Time Immemorial': The Fish-in Movement and the Rise of Intertribal Activism." Pacific Historical Review 78, no. 3 (August 1, 2009): 40334.

Smith, Eric Alden, and Mark Wishnie. "Conservation and Subsistence in Small-Scale Societies." Annual Review of Anthropology 29, no. 1 (2000): 493-524.

Taylor, Joseph E., III. "Burning the Candle at Both Ends: Historicizing Overfishing in Oregon's Nineteenth-Century Salmon Fisheries.” Environmental History 4, no. 1 (January 1, 1999): 54-79.

Townsend, Mike. "Congressional Abrogation of Indian Treaties: Reevaluation and Reform.” The Yale Law Journal 98, no. 4 (1989): 793-812.

Van Arsdol, Ted. "We Destroy and Indian Shrine." Man's Life 3, no. 2 (January 1955).

Villeneuve, Matthew. “"The Job Was Big and the Man Doing It Was Still Bigger': The Forgotten Role of Thomas B. Watters in Klamath Termination, 1953-1958." Oregon Historical Quarterly 116, no. 1 (2015): 40-67. 
Warrior, Robert Allen. "Reading American Indian Intellectual Traditions." World Literature Today 66, no. 2 (1992): 236-40.

Weaver, Timothy. "Litigation and Negotiation: The History of Salmon in the Columbia River Basin.” Ecology Law Quarterly 24, no. 4 (September 1, 1997): 677.

White, Richard. "American Environmental History: The Development of a New Historical Field." Pacific Historical Review 54, no. 3 (August 1, 1985): 297-335.

Wolfe, Patrick. "Land, Labor, and Difference: Elementary Structures of Race." The American Historical Review 106, no. 3 (2001): 866-905.

Woods, Fronda. "Who's in Charge of Fishing?" Oregon Historical Quarterly 106, no. 3 (October 1, 2005): 412-41.

\section{Books and Unpublished Manuscripts}

Ackerman, Lillian A. A Necessary Balance: Gender and Power among Indians of the Columbia Plateau. Norman: University of Oklahoma Press, 2003.

Allen, Cain. “"They Called It Progress': Indians, Salmon, and the Industrialization of the Columbia River." $\quad$ M.A. Thesis, Portland State University, 2000.

Aguilar, George. When the River Ran Wild!: Indian Traditions on the Mid-Columbia and the Warm Springs Reservation. Seattle: University of Washington Press, 2005.

Arnold, Laurie. Bartering with the Bones of Their Dead: The Colville Confederated Tribes and Termination. Seattle: University of Washington Press, 2012.

Axtell, James. Natives and Newcomers: The Cultural Origins of North America. New York: Oxford University Press, 2000.

Barber, Katrine. Death of Celilo Falls. Seattle: University of Washington Press, 2005.

Barker, Joanne, ed. Sovereignty Matters: Locations of Contestation and Possibility in Indigenous Struggles for Self-Determination. Lincoln: University of Nebraska Press, 2005.

Basso, Keith H. Wisdom Sits in Places: Landscape and Language Among the Western Apache. Albuquerque: University of New Mexico Press, 1996.

Bataille, Gretchen M., David Mayer Gradwohl, and Charles L. P. Silet, eds. The Worlds between Two Rivers: Perspectives on American Indians in Iowa. Iowa City, IA: University Of Iowa Press, 2000. 
Bear, Luther Standing. Land of the Spotted Eagle. Lincoln: University of Nebraska Press, 2006 (reprint).

Berg, Laura. "As Long As the Rivers-Run: A History of U.S. v. Oregon and Four Tribes' Fight for Columbia River Salmon” Unpublished Manuscript. Portland: Columbia River Inter-Tribal Fish Commission, 1992.

Black, Henry Campbell. Black's Law Dictionary: Second Edition. Union, N.J: The Lawbook Exchange, Ltd., 1995.

Blackhawk, Ned. Violence over the Land: Indians and Empires in the Early American West. Cambridge, Mass.: Harvard University Press, 2008.

Borstelmann, Thomas. The Cold War and the Color Line: American Race Relations in the Global Arena. Cambridge, Mass.: Harvard University Press, 2003.

Boyd, Robert. People of The Dalles: The Indians of Wascopam Mission. Lincoln: University of Nebraska Press, 2004.

- The Coming of the Spirit of Pestilence: Introduced Infectious Diseases and Population Decline among Northwest Indians, 1774-1874. Seattle: University of Washington Press, 1999.

Bramwell, Lincoln. Wilderburbs: Communities on Nature's Edge. Seattle: University of Washington Press, 2014.

Brock, Peggy. The Many Voyages of Arthur Wellington Clah: A Tsimshian Man on the Pacific Northwest Coast. Vancouver, BC: University of British Columbia Press, 2011.

Brooks, Karl Boyd. Public Power, Private Dams: The Hells Canyon High Dam Controversy. Seattle: University of Washington Press, 2006.

Bruyneel, Kevin. The Third Space of Sovereignty: The Postcolonial Politics of U.S.Indigenous Relations. Minneapolis: University Of Minnesota Press, 2007.

Butler, B. Robert. "The Physical Stratigraphy of Wakemap Mound: A New Interpretation.” M.A. Thesis, University of Washington, 1960.

Cahill, Cathleen D. Federal Fathers and Mothers: A Social History of the United States Indian Service, 1869-1933. Chapel Hill: The University of North Carolina Press, 2011.

Carlson, Keith Thor. The Power of Place Problem of Time: Aboriginal Identity and Historical Consciousness in the Cauldron of Colonialism. Toronto: University of Toronto Press, 2010. 
Carpio, Myla Vicenti, and P. Jane Hafen. Indigenous Albuquerque. Lubbock, Tex: Texas Tech University Press, 2011.

Cohen, Fay G, Joan La France, Vivian L Bowden. Treaties on Trial: The Continuing Controversy over Northwest Indian Fishing Rights. Seattle: University of Washington Press, 1986.

Cronon, William. Uncommon Ground: Rethinking the Human Place in Nature. New York: W. W. Norton \& Company, 1996.

Cruikshank, Julie. Life Lived Like a Story: Life Stories of Three Yukon Native Elders. Lincoln: University of Nebraska Press, 1992.

Deloria, Jr, Vine. Custer Died for Your Sins, an Indian Manifesto. New York: Macmillan, 1969.

Deloria, Philip Joseph. Indians in Unexpected Places. Lawrence: University Press of Kansas, 2004.

DeVoto, Bernard and Wallace Stegner, The Letters of Bernard DeVoto, (New York: Doubleday, 1975)

Dompier, Douglas W. The Fight of the Salmon People: Blending Tribal Tradition with Modern Science to Save Sacred Fish. Bloomington, IN: Xlibris, 2005.

Drukman, Mason. Wayne Morse: A Political Biography. Portland: Oregon Historical Society Press, 2004.

Dupris, Joseph C, Kathleen S Hill, and William H Rodgers. The Si 'lailo Way: Indians, Salmon, and Law on the Columbia River. Durham, N.C.: Carolina Academic Press, 2006.

Durbin, Kathie. Bridging a Great Divide: The Battle for the Columbia River Gorge. Corvallis: Oregon State University Press, 2013.

Eastman, Charles Alexander. Indian Boyhood. New York: McClure, Phillips, 1902.

Fahey, John. Saving the Reservation: Joe Garry and the Battle to Be Indian. Seattle: University of Washington Press, 2015.

Farge, Arlette, and Natalie Zemon Davis. The Allure of the Archives. Translated by Thomas Scott-Railton. New Haven, Conn.: Yale University Press, 2015.

Fiege, Mark. Irrigated Eden: The Making of an Agricultural Landscape in the American West. Seattle: University of Washington Press, 1999

Fine-Dare, Kathleen S. Grave Injustice: The American Indian Repatriation Movement and NAGPRA. Lincoln: University of Nebraska Press, 2002. 
Fisher, Andrew H. Shadow Tribe: The Making of Columbia River Indian Identity. Seattle: University of Washington Press, 2010.

Fixico, Donald L. The American Indian Mind in a Linear World: American Indian Studies and Traditional Knowledge. New York: Routledge, 2003.

- Indian Resilience and Rebuilding: Indigenous Nations in the Modern American West. Tucson: University of Arizona Press, 2013.

Fryer, Heather. Perimeters of Democracy: Inverse Utopias and the Wartime Social Landscape in the American West. Lincoln: University of Nebraska Press, 2010.

Goble, Dale D., and Paul W. Hirt. Northwest Lands, Northwest Peoples: Readings in Environmental History. University of Washington Press, 2012.

Guha, Ranajit. Dominance without Hegemony: History and Power in Colonial India. Cambridge: Harvard University Press, 1998.

Harmon, Alexandra. Indians in the Making: Ethnic Relations and Indian Identities around Puget Sound. Berkeley: University of California Press, 2000.

- Power of Promises: Rethinking Indian Treaties in the Pacific Northwest. Seattle: University of Washington Press, 2008.

Harris, Douglas C. Fish, Law, and Colonialism: The Legal Capture of Salmon in British Columbia. Toronto: University of Toronto Press, 2001.

Harvey, Mark W. T. A Symbol of Wilderness: Echo Park and the American Conservation Movement. Seattle: University of Washington Press, 2000.

- Wilderness Forever: Howard Zahniser and the Path to the Wilderness Act. Seattle: University of Washington Press, 2009.

Hays, Samuel P. Conservation And The Gospel Of Efficiency: The Progressive Conservation Movement, 1890-1920. Pittsburgh: University of Pittsburgh Press, 1999.

Hopkins, Sarah Winnemucca. Life Among the Paiutes: Their Wrongs and Claims. Reno: University of Nevada Press, 1883.

Hosmer, Brian, Shepard Krech III, and Judith Antell. Native Americans and the Environment: Perspectives on the Ecological Indian. Edited by Michael E. Harkin and David Rich Lewis. Lincoln: University of Nebraska Press, 2007.

Hoxie, Frederick. This Indian Country: American Indian Activists and the Place They Made. New York: Penguin, 2012. 
Hunn, Eugene S, and James Selam. Nch 'i-Wána, “the Big River”: Mid-Columbia Indians and Their Land. Seattle: University of Washington Press, 1990.

Hurt, Paul W. A Conspiracy of Optimism: Management of the National Forests Since World War Two. Lincoln: University of Nebraska Press, 1994.

Isenberg, Andrew C. The Destruction of the Bison: An Environmental History, 17501920. New York: Cambridge University Press, 2001.

Iverson, Peter. Carlos Montezuma and the Changing World of American Indians. Albuquerque: University of New Mexico Press, 1982.

- When Indians Became Cowboys: Native Peoples and Cattle Ranching in the American West. Norman: University of Oklahoma Press, 1994.

Jacob, Michelle M. Yakama Rising: Indigenous Cultural Revitalization, Activism, and Healing. Tucson: University of Arizona Press, 2014.

Jacoby, Karl. Crimes against Nature: Squatters, Poachers, Thieves, and the Hidden History of American Conservation. Berkeley: University of California Press, 2003.

Johansen, Dorothy O. Empire of the Columbia: A History of the Pacific Northwest. New York: Harper Collins, 1967.

Karson, Jennifer. Wiyaxayxt / Wiyaakaa'awn / As Days Go By: Our History, Our Land, Our People--The Cayuse, Umatilla, and Walla Walla. Seattle: University of Washington Press, 2006.

Krech, Shepard. The Ecological Indian: Myth and History. New York: W.W. Norton \& Co., 1999.

Landeen, Dan, and Allen Pinkham. Salmon and His People: Fish and Fishing in Nez Perce Culture. Lewiston, Idaho: Confluence Press, 1999.

Lichatowich, James A. Salmon Without Rivers: A History Of The Pacific Salmon Crisis. Washington, D.C.: Island Press, 2001.

Matsuda, Mari J. Called from Within: Early Women Lawyers of Hawai ' $i$. University of Hawaii Press, 1992.

McCool, Daniel, Susan M. Olson, and Jennifer L. Robinson. Native Vote: American Indians, the Voting Rights Act, and the Right to Vote. Cambridge: Cambridge University Press, 2007.

McEvoy, Arthur F. The Fisherman's Problem: Ecology and Law in the California Fisheries, 1850-1980. Cambridge: Cambridge University Press, 1990. 
McNickle, D’Arcy. The Surrounded. Albuquerque: University of New Mexico Press, 1978.

Monroe, Barbara. Plateau Indian Ways with Words: The Rhetorical Tradition of the Tribes of the Inland Pacific Northwest. Pittsburgh: University of Pittsburgh Press, 2014.

Nabokov, Peter. A Forest of Time: American Indian Ways of History. New York: Cambridge University Press, 2002.

Nadasdy, Paul. Hunters and Bureaucrats: Power, Knowledge, and Aboriginal-State Relations in the Southwest Yukon. Vancouver, B.C.: University of British Columbia Press, 2005.

Neuberger, Richard. They Never Go Back to Pocatello: The Selected Essays of Richard Neuberger. Edited by Steve Neal. Portland: Oregon Historical Society Press, 1989.

Neuberger, Richard Lewis. Our Promised Land. New York: The Macmillan Company, 1938.

Parfrey, Adam. It's a Man's World: Men's Adventure Magazines: The Postwar Pulps. (Port Townsend, WA: Feral House, 2003).

Pevar, Stephen. The Rights of Indians and Tribes. New York: Oxford University Press, 2012.

Philpott, William. Vacationland: Tourism and Environment in the Colorado High Country, Seattle: University of Washington Press, 2013.

Poetschat, George R., Harvey Steele, and Oregon Archaeological Society. The Formative Years of the Oregon Archaeological Society: Screenings Newsletters 1951 through January 1955. Publication (Oregon Archaeological Society) ; No. 10. Portland: Oregon Archaeological Society, 1997.

Prucha, Francis Paul. The Great Father: The United States Government and the American Indians. Abridged edition. Lincoln: University of Nebraska Press, 1986.

Raibmon, Paige. Authentic Indians: Episodes of Encounter from the Late-NineteenthCentury Northwest Coast. Durham, N.C.: Duke University Press, 2005.

Reid, Joshua L. The Sea Is My Country: The Maritime World of the Makahs. New Haven: Yale University Press, 2015. 
Relander, Click. Drummers and Dreamers: the story of Smowhala the Prophet and His Nephew Puck Hyah Toot, the Last Prophet of the Nearly Extinct River People, the Last Wanapums. Caldwell, Idaho: Caxton Printers, 1956.

Reyes, Lawney L. White Grizzly Bear's Legacy: Learning to Be Indian. Seattle: University of Washington Press, 2002.

Richardson, Elmo. Dams, Parks and Politics: Resource Development and Preservation the Truman-Eisenhower Era. Lexington: University Press of Kentucky, 2015.

Robbins, William G. Landscapes of Conflict: The Oregon Story, 1940-2000. University of Washington Press, 2009.

- Landscapes of Promise: The Oregon Story, 1800-1940. University of Washington Press, 1999.

Roderick. Nash. Wilderness and the American Mind. New Haven, Yale University Press, 1967.

Rome, Adam. The Bulldozer in the Countryside: Suburban Sprawl and the Rise of American Environmentalism. Cambridge: Cambridge University Press, 2001.

Ronda, James P. Lewis and Clark among the Indians. Lincoln: Bison Books, 2002.

Roseberry, William. Anthropologies and Histories: Essays in Culture, History, and Political Economy. New Brunswick: Rutgers University Press, 1989.

Rosier, Paul C. Serving Their Country: American Indian Politics and Patriotism in the Twentieth Century. Cambridge: Harvard University Press, 2012.

Rothman, Hal K. The Greening of a Nation?: Environmentalism in the U.S. Since 1945. Fort Worth, Tex.: Wadsworth, 1997.

Ruby, Robert H. Half-Sun on the Columbia: A Biography of Chief Moses. Norman: University of Oklahoma Press, 1995.

Ruby, Robert H., and John A. Brown. Dreamer-Prophets of the Columbia Plateau: Smohalla and Skolaskin. Norman: University of Oklahoma Press, 2002.

Ruby, Robert H., and John Arthur Brown. The Cayuse Indians: Imperial Tribesmen of Old Oregon. Norman: University of Oklahoma Press, 2005.

Sapir, Edward, and Jeremiah Curtin. Wishram Texts. Leyden, Late E.J. Brill, 1909. http://archive.org/details/wishramtexts00sapirich.

Schlick, Mary Dodds. Columbia River Basketry: Gift of the Ancestors, Gift of the Earth. Seattle: University of Washington Press, 1994. 
Scott, James C. Domination and the Arts of Resistance: Hidden Transcripts. New Haven: Yale University Press, 1992.

- Seeing like a State: How Certain Schemes to Improve the Human Condition Have Failed. Yale University Press, 1999.

Seaman, N. G. Indian Relics of the Pacific Northwest. Portland: Binford \& Mort Pub, 1980 .

Seufert, Francis. Wheels of Fortune. Portland: Oregon Historical Society Press, 1981.

Shiner, Joel L. Excavations at Site 35-WS-5 on the Columbia River, Oregon. Columbia Basin Project, River Basin Surveys, Smithsonian Institution, 1953.

Shreve, Bradley G. Red Power Rising: The National Indian Youth Council and the Origins of Native Activism. Norman: University of Oklahoma Press, 2012.

Smith, Courtland. Salmon Fishers of the Columbia. Corvallis: Oregon State University Press, 1980.

Smith, Linda Tuhiwai. Decolonizing Methodologies: Research and Indigenous Peoples. Dunedin, New Zealand: Otago University Press, 1999.

Smith, Sherry L. Hippies, Indians, and the Fight for Red Power. New York: Oxford University Press, 2012.

Spence, Mark David. Dispossessing the Wilderness: Indian Removal and the Making of the National Parks. New York: Oxford University Press, 2000.

Steedman, Carolyn. Dust: The Archive and Cultural History. New Brunswick, N.J: Rutgers University Press, 2002.

Stein, Harry H. Gus J. Solomon: Liberal Politics, Jews, and the Federal Courts. Portland: Oregon Historical Society Press, 2006.

Strong, Emory. Stone Age on the Columbia River. Portland: Binford \& Mort, 1959.

Taylor, Joseph E III. Making Salmon: An Environmental History of the Northwest Fisheries Crisis. Seattle: University of Washington Press, 1999.

Thornton, Thomas F. Being and Place among the Tlingit. Seattle: University of Washington Press, 2007.

Tonkovich, Nicole. The Allotment Plot: Alice C. Fletcher, E. Jane Gay, and Nez Perce Survivance. Lincoln: University of Nebraska Press, 2012.

Tuan, Yi-Fu. Space and Place: The Perspective of Experience. Minneapolis: University of Minnesota Press, 1977. 
Ulrich, Roberta. American Indian Nations from Termination to Restoration, 1953-2006. Lincoln: University of Nebraska Press, 2013.

- Empty Nets: Indians, Dams, and the Columbia River. Corvallis: Oregon State University Press, 2007.

Underhill, Ruth. Indians of the Pacific Northwest. Washington D.C.: Bureau of Indian Affairs, 1944.

Vizenor, Gerald. Manifest Manners: Narratives on Postindian Survivance. Lincoln: University of Nebraska Press, 1999.

Press, 2008.

Warren, Louis S. The Hunter's Game: Poachers and Conservationists in TwentiethCentury America. New Haven: Yale University Press, 1999.

Weisiger, Marsha L. Dreaming of Sheep in Navajo Country. Seattle: University of Washington Press, 2009.

West, Elliott. The Last Indian War: The Nez Perce Story. New York: Oxford University Press, 2011.

Wester, Barbara Leibhardt. Land Divided by Law: The Yakama Indian Nation as Environmental History, 1840-1933. New Orleans: Quid Pro, 2014.

Whaley, Gray H. Oregon and the Collapse of Illahee: U.S. Empire and the Transformation of an Indigenous World, 1792-1859. Chapel Hill: University of North Carolina Press, 2010.

White, Richard. The Organic Machine the Remaking of the Columbia River. New York: Hill and Wang, 1996.

Wilkinson, Charles F. Blood Struggle: The Rise of Modern Indian Nations. New York: W. W. Norton \& Company, 2006.

Wilkinson, Charles F, Adams, Henry, and Diane Sylvain. Messages from Franks Landing: A Story of Salmon, Treaties, and the Indian Way. Seattle: University of Washington Press, 2005.

Youst, Lionel and William R. Seaburg. Coquelle Thompson Athabaskan Witness: A Cultural Biography. Norman: University of Oklahoma Press, 2002. 


\title{
Appendix A
}

\section{Yakama Nation Treaty of 1855}

\author{
June 9, 1855. | 12 Stat., 951. | Ratified Mar. 8, 1859. | Proclaimed Apr. 18, 1859.
}

Articles of agreement and convention made and concluded at the treaty-ground, Camp Stevens, WallaWalla Valley, this ninth day of June, in the year one thousand eight hundred and fifty-fire, by and between Isaac I. Stevens, governor and superintendent of Indian affairs for the Territory of Washington, on the part of the United States, and the undersigned head chiefs, chiefs, head-men, and delegates of the Yakama, Palouse, Pisquouse, Wenatshapam, Klikatat, Klinquit, Kow-was-say-ee, Li-ay-was, Skin-pah, Wish-ham. Shyiks, Ochechotes, Kah milt-pah, and Se-ap-cat, confederated tribes and bands of Indians, occupying lands hereinafter bounded and described and lying in Washington Territory, who for the purposes of this treaty are to be considered as one nation, under the name of "Yakama," "with Kamaiakun as its head chief, on behalf of and acting for said tribes and bands, and being duly authorized thereto by them.

\section{ARTICLE 1.}

The aforesaid confederated tribes and bands of Indians hereby cede, relinquish, and convey to the United States all their right, title, and interest in and to the lands and country occupied and claimed by them, and bounded and described as follows, to wit:

Commencing at Mount Ranier, thence northerly along the main ridge of the Cascade Mountains to the point where the northern tributaries of Lake Che-lan and the southern tributaries of the Methow River have their rise; thence southeasterly on the divide between the waters of Lake Che-lan and the Methow River to the Columbia River; thence, crossing the Columbia on a true east course, to a point whose longitude is one hundred and nineteen degrees and ten minutes, $\left(119 \mathrm{E}^{\circ} 10^{\prime}\right)$ which two latter lines separate the above confederated tribes and bands from the Oakinakane tribe of Indians; thence in a true south course to the forty-seventh $\left(47 \mathrm{E}^{\circ}\right)$ parallel of latitude: thence east on said parallel to the main Palouse River, which two latter lines of boundary separate the above confederated tribes and bands from the Spokanes; thence down the Palouse River to its junction with the Moh-hah-ne-she, or southern tributary of the same; thence in a southesterly direction, to the Snake River, at the mouth of the Tucannon River, separating the above confederated tribes from the Nez Percéé tribe of Indians; thence down the Snake River to its junction with the Columbia River; thence up the Columbia River to the "“'White Banks"” below the Priest'"s Rapids; thence westerly to a lake called "“La Lac;"” thence southerly to a point on the Yakama River called Tohmah-luke; thence, in a southwesterly direction, to the Columbia River, at the western extremity of the "“"Big Island,"' between the mouths of the Umatilla River and Butler Creek; all which latter boundaries separate the above confederated tribes and bands from the Walla-Walla, Cayuse, and Umatilla tribes and bands of Indians; thence down the Columbia River to midway between the mouths of White Salmon and Wind Rivers; thence along the divide between said rivers to the main ridge of the Cascade Mountains; and thence along said ridge to the place of beginning.

\section{ARTICLE 2.}

There is, however, reserved, from the lands above ceded for the use and occupation of the aforesaid confederated tribes and bands of Indians, the tract of land included within the following boundaries, to wit: Commencing on the Yakama River, at the mouth of the Attah-nam River; thence westerly along said Attahnam River to the forks; thence along the southern tributary to the Cascade Mountains; thence southerly along the main ridge of said mountains, passing south and east of Mount Adams, to the spur whence flows the waters of the Klickatat and Pisco Rivers; thence down said spur to the divide between the waters of said 
rivers; thence along said divide to the divide separating the waters of the Satass River from those flowing into the Columbia River; thence along said divide to the main Yakama, eight miles below the mouth of the Satass River; and thence up the Yakama River to the place of beginning.

All which tract shall be set apart and, so far as necessary, surveyed and marked out, for the exclusive use and benefit of said confederated tribes and bands of Indians, as an Indian reservation; nor shall any white man, excepting those in the employment of the Indian Department, be permitted to reside upon the said reservation without permission of the tribe and the superintendent and agent. And the said confederated tribes and bands agree to remove to, and settle upon, the same, within one year after the ratification of this treaty. In the mean time it shall be lawful for them to reside upon any ground not in the actual claim and occupation of citizens of the United States; and upon any ground claimed or occupied, if with the permission of the owner or claimant.

Guaranteeing, however, the right to all citizens of the United States to enter upon and occupy as settlers any lands not actually occupied and cultivated by said Indians at this time, and not included in the reservation above named. And provided, That any substantial improvements heretofore made by any Indian, such as fields enclosed and cultivated, and houses erected upon the lands hereby ceded, and which he may be compelled to abandon in consequence of this treaty, shall be valued, under the direction of the President of the United States, and payment made therefor in money; or improvements of an equal value made for said Indian upon the reservation. And no Indian will be required to abandon the improvements aforesaid, now occupied by him, until their value in money, or improvements of an equal value shall be furnished him as aforesaid.

\section{ARTICLE 3.}

And provided, That, if necessary for the public convenience, roads may be run through the said reservation; and on the other hand, the right of way, with free access from the same to the nearest public highway, is secured to them; as also the right, in common with citizens of the United States, to travel upon all public highways.

The exclusive right of taking fish in all the streams, where running through or bordering said reservation, is further secured to said confederated tribes and bands of Indians, as also the right of taking fish at all usual and accustomed places, in common with the citizens of the Territory, and of erecting temporary buildings for curing them; together with the privilege of hunting, gathering roots and berries, and pasturing their horses and cattle upon open and unclaimed land.

\section{ARTICLE 4.}

In consideration of the above cession, the United States agree to pay to the said confederated tribes and bands of Indians, in addition to the goods and provisions distributed to them at the time of signing this treaty, the sum of two hundred thousand dollars, in the following manner, that is to say: Sixty thousand dollars, to be expended under the direction of the President of the United States, the first year after the ratification of this treaty, in providing for their removal to the reservation, breaking up and fencing farms, building houses for them, supplying them with provisions and a suitable outfit, and for such other objects as he may deem necessary, and the remainder in annuities, as follows: For the first five years after the ratification of the treaty, ten thousand dollars each year, commencing September first, 1856; for the next five years, eight thousand dollars each year; for the next five years, six thousand dollars per year; and for the next five years, four thousand dollars per year. All which sums of money shall be applied to the use and benefit of said Indians, under the direction of the President of the United States, who may from time to time determine, at his discretion, upon what beneficial objects to expend the same for them. And the 
superintendent of Indian affairs, or other proper officer, shall each year inform the President of the wishes of the Indians in relation thereto.

\section{ARTICLE 5.}

The United States further agree to establish at suitable points within said reservation, within one year after the ratification hereof, two schools, erecting the necessary buildings, keeping them in repair, and providing them with furniture, books, and stationery, one of which shall be an agricultural and industrial school, to be located at the agency, and to be free to the children of the said confederated tribes and bands of Indians, and to employ one superintendent of teaching and two teachers; to build two blacksmiths" shops, to one of which shall be attached a tin-shop, and to the other a gunsmith's shop; one carpenter's shop, one wagon and plough maker's shop, and to keep the same in repair and furnished with the necessary tools; to employ one superintendent of farming and two farmers, two blacksmiths, one tanner, one gunsmith, one carpenter, one wagon and plough maker, for the instruction of the Indians in trades and to assist them in the same; to erect one saw-mill and one flouring-mill, keeping the same in repair and furnished with the necessary tools and fixtures; to erect a hospital, keeping the same in repair and provided with the necessary medicines and furniture, and to employ a physician; and to erect, keep in repair, and provided with the necessary furniture, the building required for the accommodation of the said employees. The said buildings and establishments to be maintained and kept in repair as aforesaid, and the employees to be kept in service for the period of twenty years.

And in view of the fact that the head chief of the said confederated tribes and bands of Indians is expected, and will be called upon to perform many services of a public character, occupying much of his time, the United States further agree to pay to the said confederated tribes and bands of Indians five hundred dollars per year, for the term of twenty years after the ratification hereof, as a salary for such person as the said confederated tribes and bands of Indians may select to be their head chief, to build for him at a suitable point on the reservation a comfortable house, and properly furnish the same, and to plough and fence ten acres of land. The said salary to be paid to, and the said house to be occupied by, such head chief so long as he may continue to hold that office.

And it is distinctly understood and agreed that at the time of the conclusion of this treaty Kamaiakun is the duly elected and authorized head chief of the confederated tribes and bands aforesaid, styled the Yakama Nation, and is recognized as such by them and by the commissioners on the part of the United States holding this treaty; and all the expenditures and expenses contemplated in this article of this treaty shall be defrayed by the United States, and shall not be deducted from the annuities agreed to be paid to said confederated tribes and band of Indians. Nor shall the cost of transporting the goods for the annuity payments be a charge upon the annuities, but shall be defrayed by the United States.

\section{ARTICLE 6.}

The President may, from time to time, at his discretion, cause the whole or such portions of such reservation as he may think proper, to be surveyed into lots, and assign the same to such individuals or families of the said confederated tribes and bands of Indians as are willing to avail themselves of the privilege, and will locate on the same as a permanent home, on the same terms and subject to the same regulations as are provided in the sixth article of the treaty with the Omahas, so far as the same may be applicable.

\section{ARTICLE 7.}

The annuities of the aforesaid confederated tribes and bands of Indians shall not be taken to pay the debts of individuals. 


\section{ARTICLE 8.}

The aforesaid confederated tribes and bands of Indians acknowledge their dependence upon the Government of the United States, and promise to be friendly with all citizens thereof, and pledge themselves to commit no depredations upon the property of such citizens. And should any one or more of them violate this pledge, and the fact be satisfactorily proved before the agent, the property taken shall be returned, or in default thereof, or if injured or destroyed, compensation may be made by the Government out of the annuities. Nor will they make war upon any other tribe, except in self-defence, but will submit all matters of difference between them and other Indians to the Government of the United States or its agent for decision, and abide thereby. And if any of the said Indians commit depredations on any other Indians within the Territory of Washington or Oregon, the same rule shall prevail as that provided in this article in case of depredations against citizens. And the said confederated tribes and bands of Indians agree not to shelter or conceal offenders against the laws of the United States, but to deliver them up to the authorities for trial.

\section{ARTICLE 9.}

The said confederated tribes and bands of Indians desire to exclude from their reservation the use of ardent spirits, and to prevent their people from drinking the same, and, therefore, it is provided that any Indian belonging to said confederated tribes and bands of Indians, who is guilty of bringing liquor into said reservation, or who drinks liquor, may have his or her annuities withheld from him or her for such time as the President may determine.

\section{ARTICLE 10.}

And provided, That there is also reserved and set apart from the lands ceded by this treaty, for the use and benefit of the aforesaid confederated tribes and bands, a tract of land not exceeding in quantity one township of six miles square, situated at the forks of the Pisquouse or Wenatshapam River, and known as the "“Wenatshapam Fishery,"” which said reservation shall be surveyed and marked out whenever the President may direct, and be subject to the same provisions and restrictions as other Indian reservations.

\section{ARTICLE 11.}

This treaty shall be obligatory upon the contracting parties as soon as the same shall be ratified by the President and Senate of the United States. In testimony whereof, the said Isaac I. Stevens, governor and superintendent of Indian affairs for the Territory of Washington, and the undersigned head chief, chiefs, headmen, and delegates of the aforesaid confederated tribes and bands of Indians, have hereunto set their hands and seals, at the place and on the day and year hereinbefore written.

\section{Issac I. Stevens,}

Governor and Superintendent.

Kamaiakun, his x mark.

Skloom, his x mark.

Owhi, his x mark.

Te-cole-kun, his x mark.

La-hoom, his x mark. 
Me-ni-nock, his x mark.

Elit Palmer, his x mark.

Wish-och-kmpits, his x mark.

Koo-lat-toose, his x mark.

Shee-ah-cotte, his x mark.

Tuck-quille, his x mark.

Ka-loo-as, his x mark.

Scha-noo-a, his x mark.

Sla-kish, his x mark.

Signed and sealed in the presence of-

James Doty, secretary of treaties,

Mie. Cles. Pandosy, O. M. T.,

Wm. C. McKay,

W. H. Tappan, sub Indian agent, W. T.,

C. Chirouse, O. M. T.,

Patrick McKenzie, interpreter,

A. D. Pamburn, interpreter,

Joel Palmer, superintendent Indian affairs, O. T.,

W. D. Biglow,

A. D. Pamburn, interpreter. 